\title{
Identification and Biosensing Application of Molecular Recognition Elements
}

\author{
Ka Lok Hong
}

Follow this and additional works at: https://researchrepository.wvu.edu/etd

\section{Recommended Citation}

Hong, Ka Lok, "Identification and Biosensing Application of Molecular Recognition Elements" (2015). Graduate Theses, Dissertations, and Problem Reports. 5818.

https://researchrepository.wvu.edu/etd/5818

This Dissertation is protected by copyright and/or related rights. It has been brought to you by the The Research Repository @ WVU with permission from the rights-holder(s). You are free to use this Dissertation in any way that is permitted by the copyright and related rights legislation that applies to your use. For other uses you must obtain permission from the rights-holder(s) directly, unless additional rights are indicated by a Creative Commons license in the record and/ or on the work itself. This Dissertation has been accepted for inclusion in WVU Graduate Theses, Dissertations, and Problem Reports collection by an authorized administrator of The Research Repository @ WVU.

For more information, please contact researchrepository@mail.wvu.edu. 


\title{
Identification and Biosensing Application of Molecular Recognition Elements
}

\author{
Ka Lok Hong \\ A dissertation submitted to the School of Pharmacy at \\ West Virginia University in partial fulfillment of the requirements for the \\ degree of \\ Doctor of Philosophy in Pharmaceutical and Pharmacological Sciences \\ Letha J. Sooter, Ph.D., Chair \\ Yon. Rojanasakul, Ph.D. \\ Grazyna D. Szklarz, Ph.D. \\ Erik A. Bey, Ph.D. \\ Linda Vona-Davis, Ph.D.
}

\section{Department of Pharmaceutical Sciences \\ Morgantown, West Virginia \\ 2015}

Keywords: Molecular Recognition Element, In vitro selection, SELEX, Aptamer, ssDNA, Biosensing, Bacteria Toxin, Staphylococcus aureus, Clostridium difficile, Pseudomonas aeruginosa, Pesticides, ELISA

Copyright 2015 Ka Lok Hong 


\title{
ABSTRACT
}

\section{Identification and Biosensing Application of Molecular Recognition Elements}

\author{
Ka Lok Hong
}

Molecular recognition elements (MREs) are biomolecules such as single-stranded DNA (ssDNA), RNA, small peptides and antibody fragments that can bind to user defined targets with high affinities and specificities. This binding property allows MREs to have a wide range of applications, including therapeutic, diagnostic, and biosensor applications. The identification of MREs can be achieved by using the process called Systematic Evolution of Ligands by Exponential Enrichment (SELEX). This process begins with a large library of $10^{9}$ to $10^{15}$ different random molecules, molecules that bind to the user defined target or positive target are enriched in the process. Subsequently, this process can be modified and tailored to direct the enriched library away from binding to related targets or negative targets, and thus increasing the specificity. Single-stranded DNA (ssDNA) MREs are particularly favorable for biosening applications due to their relative stability, reusability and low cost in production. This work investigated the identification and application of ssDNA MREs to detect different bacterial toxins and pesticide.

In Chapter 1, it begins by reviewing recent discovery and advancement in the SELEX technique for the identification and biosensing application of ssDNA MREs specific for bacteria, viruses, their related biomolecules, and selected environmental toxins. It is then followed by a brief discussion on major biosensing principles based upon ssDNA MREs. In Chapter 2, the pilot project of this work, ssDNA MRE specific for Pseudomonas aeruginosa exotoxin A was identified. In this chapter, a novel variation of SELEX called Decoy-SELEX, previously developed by our laboratory is described in greater detail. Additionally, the development of a ssDNA MRE modified enzyme-linked immunosorbent assay (ELISA) for the exotoxin A detection is also discussed. In Chapter 3, similar methodology was applied to identify a ssDNA MRE specific for the second target, Clostridium difficile toxin B. Subsequently, similar ssDNA MRE modified ELISA was developed for target detection in clinically relevant samples. In Chapter 4, ssDNA MRE specific for alpha toxin of Staphylococcus aureus was identified, and it was applied for sensitive detection of the target in clinically relevant samples. In Chapter 5, the overall conclusion and potential future studies as a result from this work is discussed. Lastly, in Appendix, the project of identifying and potential future application of ssDNA MREs specific for a pesticide, Fipronil is described.

Overall, this work has shown the proof-of-principle of using ssDNA MREs in biosensing application for target detections in clinically relevant samples. The work will be useful in the development of potential point-of-care diagnostic tools for rapid diagnosis of bacterial infections. 


\section{DEDICATION}

To my wife, Anne Yue Lin, for her continuous support during all these years

To my son, Kai Lin Hong, for his loveliness and the happiness he brought me

To my parents, Chang Teh Hong and Ying Ying Lok, for their wisdom in guiding me into the person I am today

\section{And}

In the loving memory of my grandmother, Yue Xin Le 


\section{ACKNOWLEDGEMENTS}

"Science, the final frontier. We are the members of the Laboratory of Sooter. Our continuing mission is to explore strange molecular worlds, to boldly select binding elements which no one has selected before."

The above quote was modified from the famous opening quote of the original Star Trek ${ }^{\circledR}$ TV series. I wrote that when I first joint the Sooter lab to express my excitement in exploring the science of molecular recognition elements. Over the years, I am truly grateful for the continuous support and mentorship of my advisor Dr. Letha Sooter. This has been the most fruitful few years of my professional life. Her guidance has nurtured not only my scientific knowledge, but also my professional integrity. I am sure what I have learnt from her will continue to influence my working habit in a positive manner for many more years. With that, I salute to the Captain of Sooter Lab!

As a member of the Sooter lab, I would also like to express my gratitude to Dr. Ryan M. Williams. He has provided me the foundation of my research work. Though I did not have a lot of chances to work with him side-by-side, I have learnt so much from his previous work and his exceptional writing skills. I am very happy to have a chance to learn from a very good scientific writer. With that, I salute to the Commander of Sooter Lab!

My committee: Dr. Yon. Rojanasakul, Dr. Grazyna Szklarz, Dr. Erik Bey, Dr. Linda Vona-Davis. All of them have been very supportive and helpful in guiding me to the completion of my dissertation work. They all deserve my deepest gratitude.

Many members of the Sooter Lab have participated directly or indirectly in this work, Kailey Yancey, Lusia Battistella, Eamonn Maher, Jessica Lear, Cyrus Hajiran, and Zachary Cox. I am truly thankful for all their help and support.

Science is huge unexplored galaxy of its own. The Sooter Lab would not have successfully navigated this far alone. Members of the Holland Lab (Chemistry), Dawson Lab (Electrical Engineering), have been very supportive. I wish this good collaboration relationship will continue. Personally, I would like to thank my close colleges and friends in the Pharmaceutical Sciences Department, Katherine Hickey, for all her help in teaching me how to use SPR, and the time in proof reading, and correcting my grammar errors on multiple occasions, Christopher Bostick, for his continuous effort in fabricating in-house gold chip for SPR experiments, Alysia Salva, for her involvement in the project, and every faculty and staff in the Department.

Lastly, I am grateful for the two-year NanoSAFE graduate fellowship support and the education opportunity WVU School of Pharmacy has given me, both Pharm.D. and Ph.D..

With my upcoming departure from the Sooter Lab and WVU School of Pharmacy, please allow me to say “Engage!" (Famous quote from Captain Picard of Star Trek, The Next Generation ${ }^{\circledR}$ ) 


\section{TABLE OF CONTENTS}

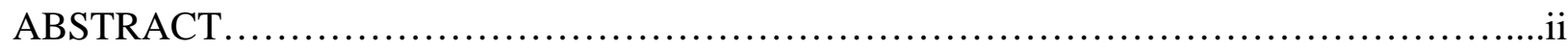

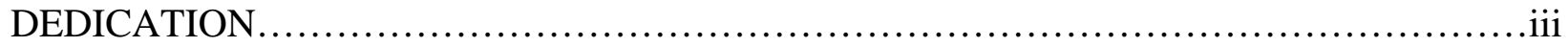

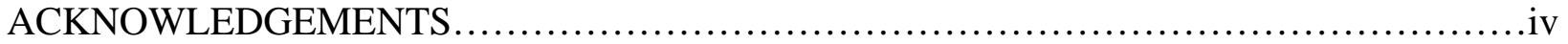

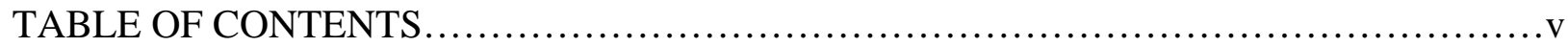

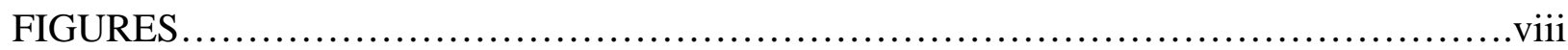

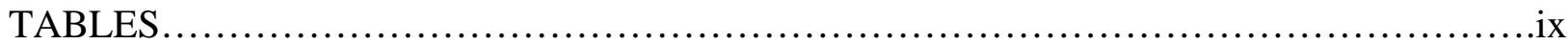

Chapter 1. Literature review: Recent Advancement in the Biosensing of Pathogens and Toxins Based on Single-Stranded DNA Molecular Recognition Elements.............................1

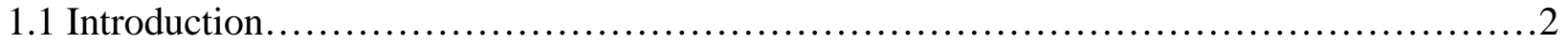

1.2 In vitro Selection of ssDNA Molecular Recognition Elements............................ 5

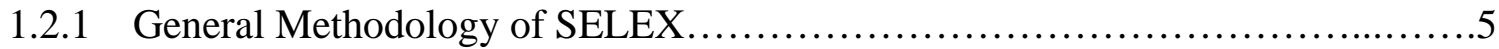

1.2.2 Examples of Modified SELEX .........................................

1.2.3 Single-stranded DNA MREs Targeting Bacteria................................10

1.2.4 Single-stranded DNA MREs Targeting Viruses.............................22

1.2.5 Single-stranded DNA MREs Targeting Toxins...............................28

1.2.5.1 Biological Toxins/ Virulence Factors...................................28

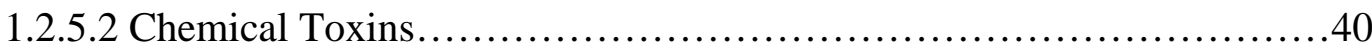

1.3 General Classes of Detection Methods................................................. 45

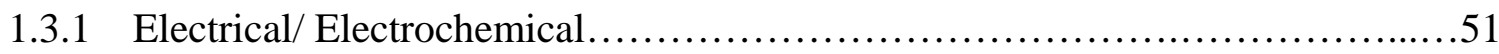

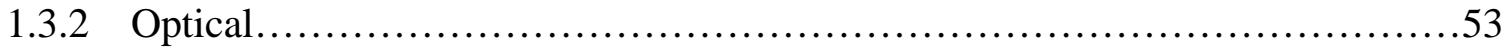

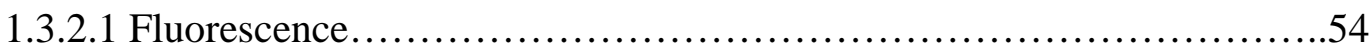

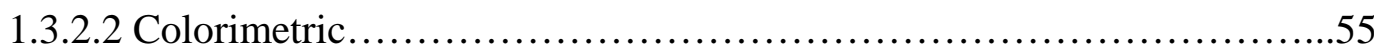

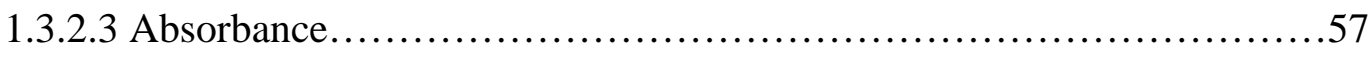

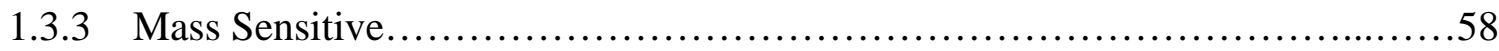

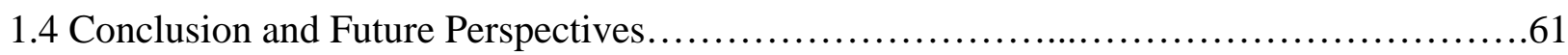

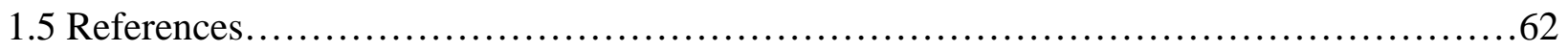

Chapter 2. Selection of Single-Stranded DNA Molecular Recognition Elements Against Exotoxin A using A Novel Decoy-SELEX Method and Sensitive Detection of Exotoxin A in

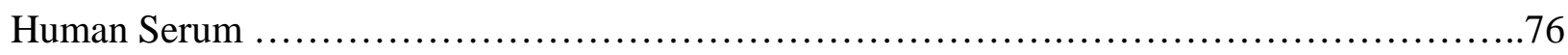

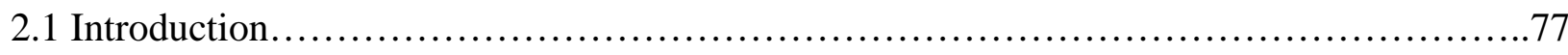

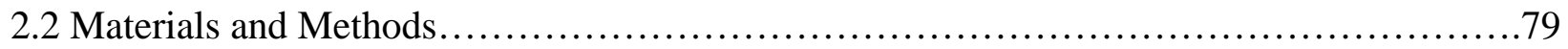

2.2.1 Decoy-SELEX Method for Selection of Exotoxin A-specific MREs...............79

2.2.2 Cloning and Sequencing of Exotoxin A-specific MREs...........................85

2.2.3 Exotoxin A-specific MRE Binding Assays with Surface Plasmon Resonance....85

2.2.4 Exotoxin A-specific MRE Modified ELISA Assays...............................87 


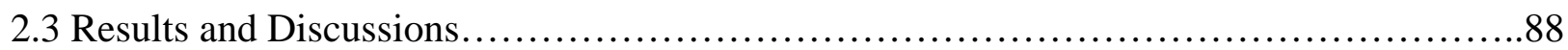

2.3.1 Selection of Exotoxin A-specific MREs.....................................88

2.3.2 Affinity and Specificity of Exotoxin A-specific MRE...........................91

2.3.3 Diagnostic Application of Exotoxin A-specific MRE.............................95

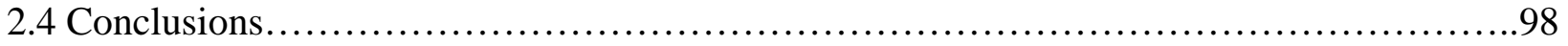

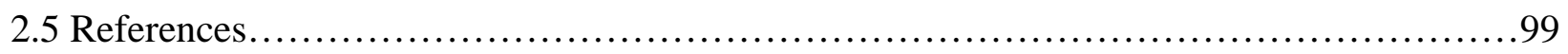

Chapter 3. In Vitro Selection of a Single-Stranded DNA Molecular Recognition Element Against Clostridium difficile Toxin B and Sensitive Detection in Human Fecal Matter.........103

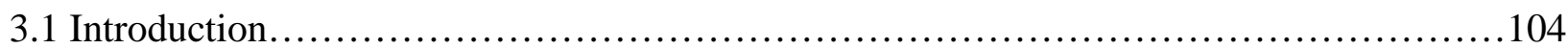

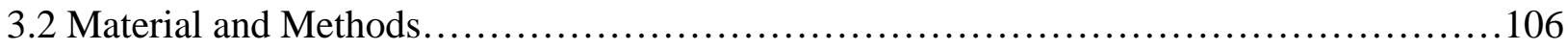

3.2.1 In Vitro Selection of Toxin B-specific MREs..............................106

3.2.2 Cloning and Sequencing of Toxin B-specific MREs............................111

3.2.3 Toxin B-specific MREs Sequence Alignment and Analysis......................112

3.2.4 Toxin B-specific MRE Binding Assays with Surface Plasmon Resonance......112

3.2.5 Toxin B-specific MRE Fluorescence Cross-Binding Assays......................114

3.2.6 Toxin B-specific MRE Modified ELISA Assays..............................115

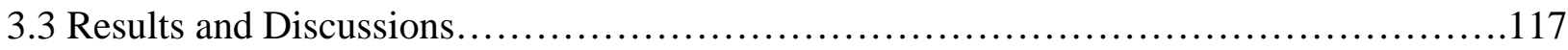

3.3.1 Identification of Toxin B-specific MRE..................................121

3.3.2 Affinity and Specificity of Toxin B-specific MRE.............................120

3.3.3 Diagnostic Application of Toxin B-specific MRE............................122

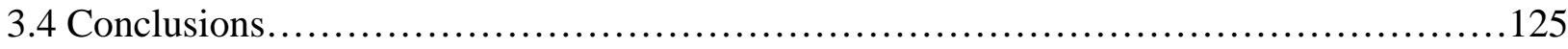

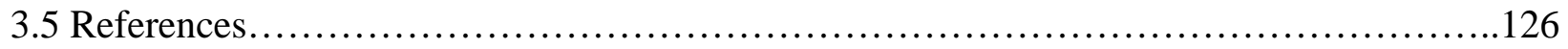

Chapter 4. In Vitro Selection of a Single-Stranded DNA Molecular Recognition Element Against S. aureus Alpha Toxin and Sensitive Detection in Human Serum......................130

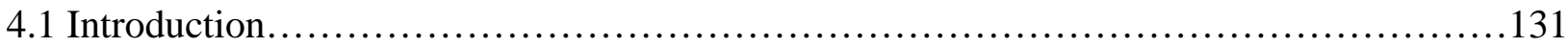

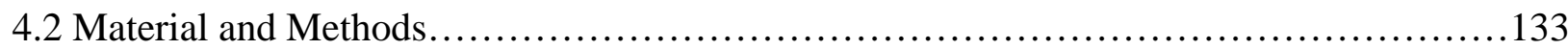

4.2.1 SELEX for Identification of Alpha Toxin-specific MREs......................133

4.2.2 Cloning and Sequencing of Alpha Toxin-specific MREs.......................137

4.2.3 Alpha Toxin-specific MRE SPR Affinity Binding Assays......................138

4.2.4 Alpha Toxin-specific MRE Fluorescence Cross Binding Assays.................129

4.2.5 Alpha-Toxin-specific MRE Modified ELISA...............................140

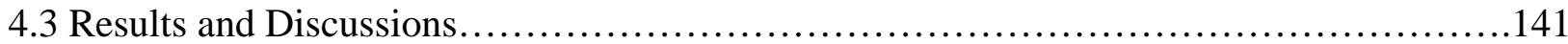

4.3.1 Identification of Alpha Toxin-specific MRE................................141

4.3.2 Affinity and Specificity of Alpha Toxin-Specific MRE...........................144

4.3.3 Diagnostic Application of Alpha Toxin-specific MRE..........................146

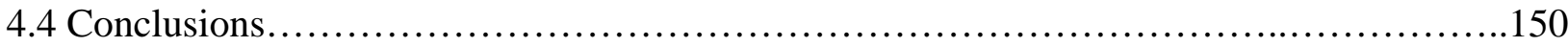

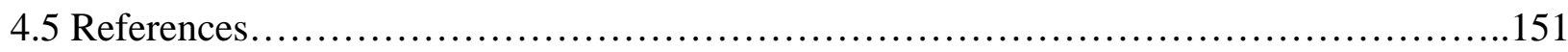


Chapter 5. Overall Conclusions and Future Studies.

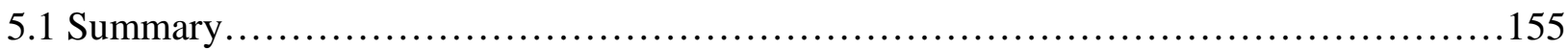

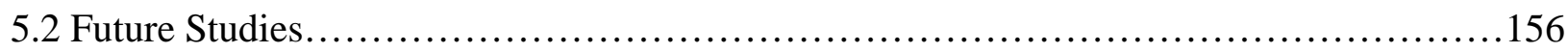

Appendix. In Vitro Selection of Single-stranded DNA Molecular Recognition Elements for the

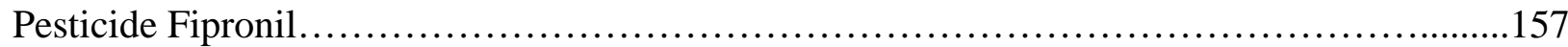

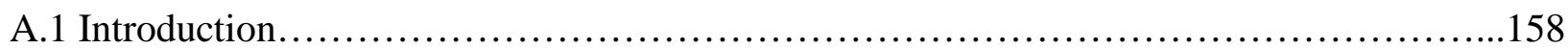

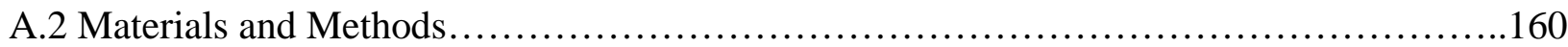

A.2.1 In vitro selection for Fipronil-specific MREs.................................160

A.3 Preliminary Results and Future Work .................................................

A.3.1 Round 12 Potential Fipronil-specific candidate MRE..........................161

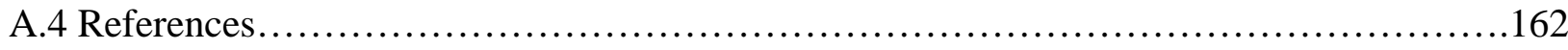

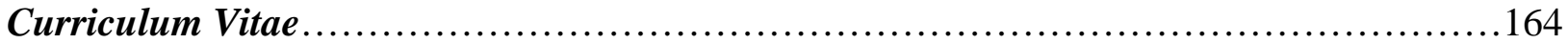




\section{LIST OF FIGURES}

Figure 1.1 Illustration of the SELEX process............................................

Figure 1.2 Illustration of examples of ssDNA MRE based electrochemical biosensors..........52

Figure 1.3 Illustration of examples of signal enhancement methods in ssDNA MRE based electrochemical biosensors..................................................... 53

Figure 1.4 Illustration of examples of ssDNA MRE based fluorescent biosensors...............54

Figure 1.5 Illustration of examples of ssDNA MRE based colorimetric biosensors...............56

Figure 1.6 Illustration of examples of ssDNA MRE modified enzyme linked assays............57

Figure 1.7 Illustration of ssDNA MRE based surface plasmon resonance biosensors...........59

Figure 1.8 Illustration of examples of ssDNA MRE based mass sensitive biosensors...........60

Figure 2.1 Illustration of the Decoy-SELEX process..................................82

Figure 2.2 Structures of targets used in the Decoy-SELEX and SPR cross binding assays.......81

Figure 2.3 Secondary structure and sequence of R14.33 ssDNA MRE $\ldots \ldots \ldots \ldots \ldots \ldots \ldots \ldots \ldots$

Figure 2.4 SPR binding kinetics assays of R14.33 ssDNA MRE.........................92

Figure 2.5 SPR cross binding assays of R14.33 ssDNA MRE...........................93

Figure 2.6 Modified ELISA assays of Exotoxin A...................................95

Figure 3.1 Illustration of the SELEX process......................................107

Figure 3.2 Structures of targets used in the SELEX scheme and cross binding assays...........109

Figure 3.3 Illustration of the Toxin B-specific MRE modified ELISA assay.................116

Figure 3.4 Sequence families of the round 12 library.................................... 118

Figure 3.5 Secondary structure and sequence of R12.69 ssDNA MRE...................119

Figure 3.6 Affinity measurements of R12.69 ssDNA MRE ...........................120

Figure 3.7 R12.69 ssDNA MRE modified ELISA assays of Toxin B.....................123

Figure 4.1 Illustration of the Systematic Evolution of Ligands by Exponential enrichment

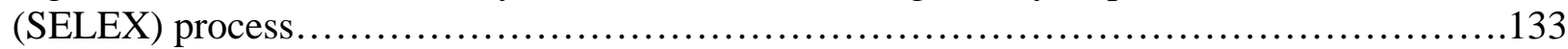

Figure 4.2 Structure of targets used in the SELEX scheme and cross binding assays............135

Figure 4.3 Sequence and secondary structure of R12.06 ssDNA MRE.....................143

Figure 4.4 Illustration of the ssDNA MRE modified ELISA assay $\ldots \ldots \ldots \ldots \ldots \ldots \ldots \ldots \ldots \ldots 14$ 
Figure 4.5 Detection of alpha toxin in modified ELISA assay ..............................148

Figure A.1 Illustration of the in vitro selection process....................................160

\section{LIST OF TABLES}

Table 1.1 Summary table of ssDNA MREs targeting bacteria and bacteria structural

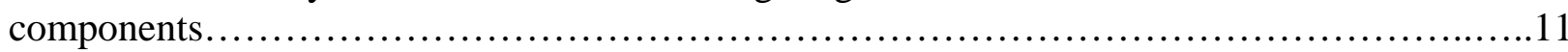

Table 1.2 Summary table of ssDNA MREs targeting viruses and virus proteins for biosensing

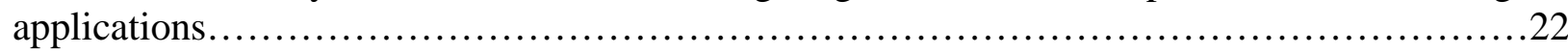

Table 1.3 Summary table of ssDNA MREs targeting viruses and virus proteins for therapeutic

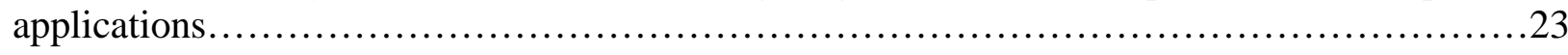

Table 1.4 Summary table of ssDNA MREs targeting biological toxins and virulence

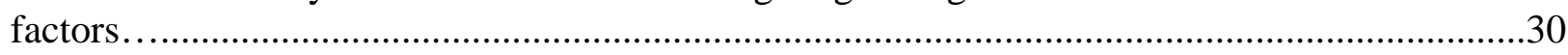

Table 1.5 Summary table of ssDNA MREs targeting chemical toxins..........................40

Table 1.6 Summary table of ssDNA MRE based biosensors for the detection of pathogens......46

Table 1.7 Summary table of ssDNA MRE based biosensors for the detection of biological

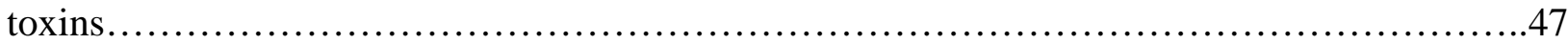

Table 1.8 Summary table of ssDNA MRE based biosensors for the detection of chemical

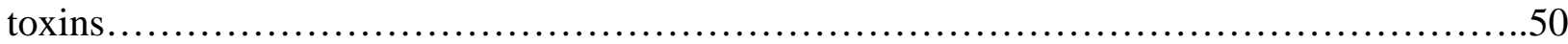

Table 2.1 Decoy-SELEX scheme for Exotoxin A MRE selection..............................79

Table 2.2 Sequence families after Round 14 Decoy-SELEX................................ 89

Table 3.1 Systematic Evolution of Ligands by Exponential Enrichment (SELEX) scheme for Toxin B-specific MRE selection..................................................... 108

Table 3.2 Cross-binding reactivity of R12.69 ssDNA MRE...............................121

Table 4.1 Systemic Evolution of Ligands by Exponential enrichment (SELEX) scheme for ssDNA molecular recognition element (MRE) identification against alpha toxin...............134

Table 4.2 Sequence families after 12 rounds of SELEX...................................142

Table 4.3 SPR affinity data of R12.06 ssDNA MRE......................................144

Table 4.4 Cross-reactivity data of R12.06 ssDNA MRE.....................................145 


\section{Chapter 1}

\section{Literature review: Recent Advancement in the Biosensing of Pathogens and Toxins Based on Single-Stranded DNA Molecular Recognition Elements}

This chapter is adapted from the work that is currently under review for publication in BioMed Research International.

Citation: Hong KL and Sooter LJ. 2015. "Single-stranded DNA Aptamers against Pathogens and Toxins: Identification and Biosensing Applications” Under review, BioMed Research International 


\subsection{Introduction}

Target detection in diagnostics and sensors relies on successful molecular recognitions. Traditionally, antibodies have been used in biosening applications due to their target specificities and affinities. However, the inherent properties of proteins give rise to many shortcomings of antibodies. In 1990, the Gold Laboratory first described a process, termed Systematic Evolution of Ligands by Exponential Enrichment (SELEX) [1], which identifies one or few molecular recognition elements (MREs) with high affinity and specificity toward their intended targets. MREs can be short sequences of single-stranded DNA, RNA, small peptides or antibody fragments. All types of MREs are capable of binding to user-defined targets with high affinity and specificity, and these targets include proteins, small molecules, viruses, whole bacteria cells and mammalian cells [2].

In order to identify nucleic acid MREs, the SELEX process generally begins from a very large random library consisting of $10^{13}$ to $10^{15}$ different molecules. An individual nucleic acid MRE is composed of two constant regions for primer attachment during polymerase chain reaction (PCR) amplification flanked by a 20-80 bases random region [3]. The target of interest is first incubated with the library under specific ionic and temperature conditions. Library molecules that bind to the target are retained and amplified by PCR, while non-binding library molecules are discarded. Negative or counter selections are often performed to increase the specificity of the library or direct the enrichment process away from binding to negative targets. Negative targets are often chosen for their structural similarities or the likelihood to coexist in the native environment with the target of interest. In this case, library molecules that bind to negative targets are discarded and those that do not bind are retained and amplified, and thus completing one round of in vitro selection (Figure 1.1). It is expected that after approximately 12 
rounds of SELEX, one or few nucleic acid MREs with high specificity and affinity toward their targets can be identified.

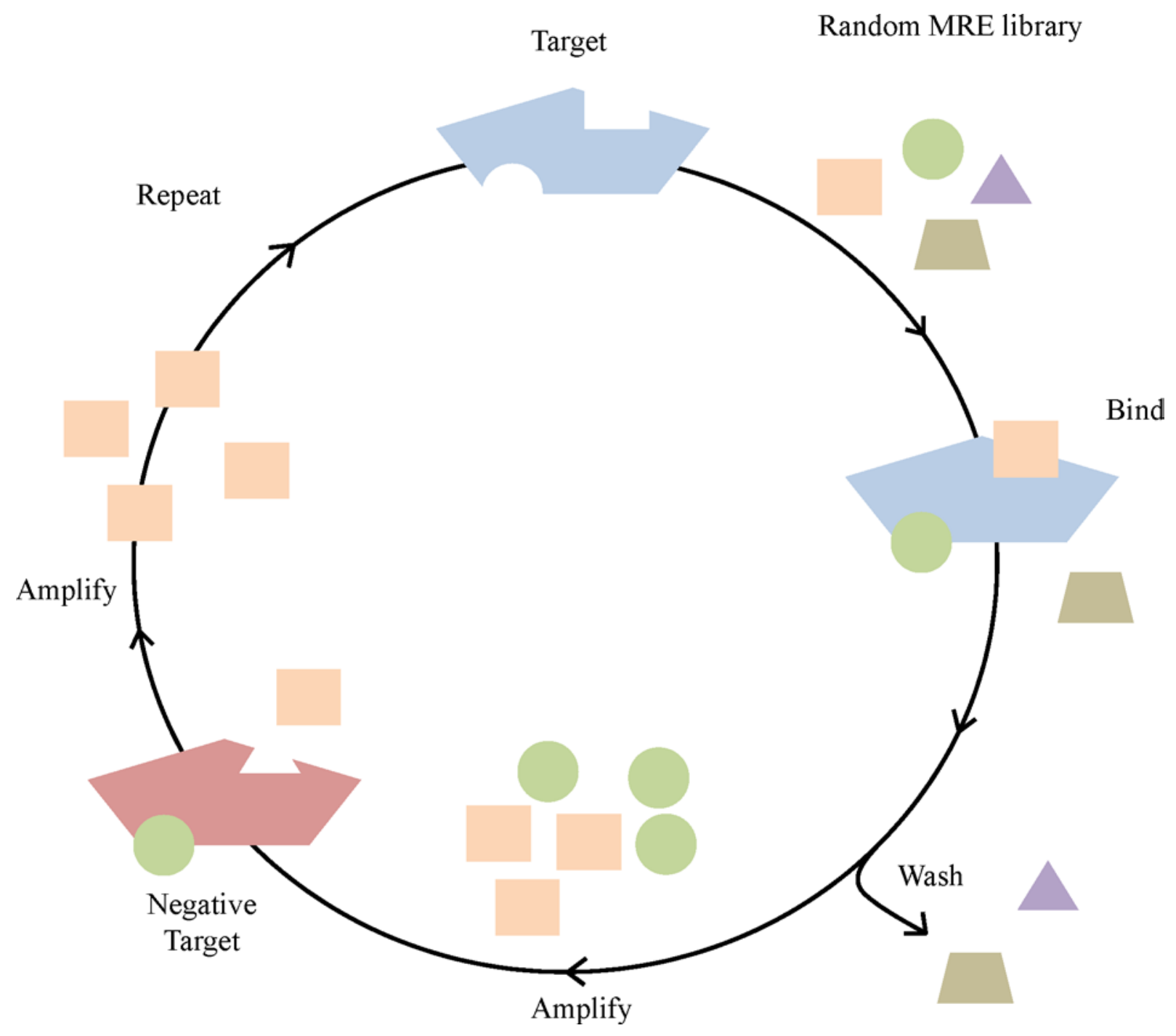

Figure 1.1: Illustration of the SELEX process. A random library consisting of up to $10^{15}$ single-stranded nucleic acids molecules are incubated with the target of interest. Those that bound to the target are retrieved and amplified by polymerase case reaction. It is then followed by incubation with negative targets. Those that do not bind to negative targets are retained, amplified and subjected to further rounds of in vitro selection. 
Both DNA and RNA MREs can conform into three dimensional structures, which include stem-loop, bulges and/or hairpin regions, give rise to binding pockets for their respective targets [4]. There are reports suggesting RNA MREs generally have a higher affinity for their target than their DNA counterparts [5]. However, unmodified RNA molecules are more susceptible to nuclease degradations than DNA. Modification on the 2' hydroxyl of RNA molecules can increase their stabilities but may have negative impact on their binding affinities [6, 7]. It is also more difficult to amplify RNA MREs during selection, as reverse transcription to DNA must be performed prior to PCR. For these given reasons, there is a bigger hurdle to successfully identify and apply RNA MREs in molecular detection, and thus this review has chosen to focus on the discussion of ssDNA MREs in biosening applications.

Single-stranded DNA MREs have high affinity and specificity toward their targets that is comparable to antibodies. In addition, ssDNA MREs have several advantages over antibodies. Firstly, ssDNA MREs are more thermostable and can be reversibly denatured. This reusability is particularly desired for molecular sensing applications. Secondly, ssDNA MREs can be identified for targets that are non-immunogenic or toxic to cells, as the SELEX process can be performed completely in vitro and independent of living systems. Lastly, identified ssDNA MREs with known sequences can be chemically synthesized at low cost and without batch to batch variations [8]. Different modifications such as thiol or amino functional groups can also be easily incorporated onto the 3' and/or 5' ends of oligonucleotides during synthesis and utilized for immobilization on solid platforms. Similarly, labeling molecules such as biotin or FITC can also be covalently attached and serve as reporters in sensing applications. The attractive features of ssDNA MREs allow researchers to investigate the translational application of biosensors. This review focuses on the recent advancements in the identification and biosensing application of 
ssDNA MREs specific for bacteria, viruses, their associated biomolecules, virulence factors, and selected biological and chemical toxins. Detection of these targets has been shown to be important in medical diagnosis, food safety and environmental monitoring. Additionally, major principles in MRE based biosensors are briefly discussed.

\subsection{In vitro Selection of ssDNA Molecular Recognition Elements}

\subsubsection{General Methodology of SELEX}

The general process of in vitro selection of ssDNA MREs starts from design and chemical synthesis of a ssDNA library. A ssDNA library consists of two pre-determined constant regions for primer attachment during PCR amplification flanking a random region. This random region gives rise to the diversity of the library, which can be designated by $4^{\mathrm{n}}$, where $\mathrm{n}$ is the number of bases in the random region. Longer random regions result in increased library diversity, but also may risk inhibition of PCR amplification due to secondary structure formation. Therefore, the overall library lengths are usually designed to be less than 150 bases, including a random region of 20 to 80 bases, and are chemically synthesized using phosphoramidite chemistry [3].

The SELEX process begins by incubating up to $10^{15}$ different ssDNA molecules with the target of interest. One of the key steps in the SELEX process is the separation of bound MREs from unbound MREs. The separation process is often achieved by target immobilization. Immobolization options include nitrocellulose membranes that can be used to adsorb protein targets [9], and histidine tags on recombinant proteins that can be with a metal affinity chromatography column [10]. However, ssDNA molecules may non-specifically adsorb to immobilizing substrates. A round of negative selection is typically performed prior to the start of the first round of positive selection to reduce the non-specific adsorption between the library and 
immobilizing substrates. Magnetic beads have also been used to immobilize a wide range of targets [11-14]. The terminal primary amine or a surface lysine on a protein can be used to conjugate onto carboxylic acid coated magnetic beads via EDC/NHS reactions. Small molecule targets or target analogs with available functional groups can also be biotinylated and immobilized on streptavidin coated magnetic beads based on the strong affinity between biotin and streptavidin [14, 15]. Magnets can then be used for the separation of bound and unbound molecules. However, this technique runs the risk of selecting MREs bound to magnetic beads and/or streptavidin. Sooter and co-workers successfully showed that competitive elution with free target can effectively isolate ssDNA MREs specific for the target of interest and not to the immobilizing substrates or analog molecules [14-16].

Amplification of the ssDNA library is also crucial to the success of the in vitro selection process. PCR conditions have to be determined and optimized before the selection process. After the retrieval of target bound ssDNA molecules for each round of selection, a small-scale PCR can be carried out to determine the cycles of PCR needed to successfully amplify the library. Large-scale PCR can subsequently be performed based on the determined number of reaction, and thus decreasing the chance of over amplification and the generation of undesired PCR amplicons.

It is necessary to obtain ssDNA from double-stranded PCR product prior to the subsequent rounds of selection. Several techniques have been shown to effectively isolate the single-stranded binding element from double-stranded DNA, such as asymmetric PCR, biotinstreptavidin separation, lambda exonuclease digestions and size separation on denaturing urea polyacrylamide gel electrophoresis. Asymmetric PCR uses a different ratio of forward and reverse primer in the reaction mixture to generate both dsDNA and ssDNA allowing the two 
types of DNA molecules to be visualized and separated using agarose gel electrophoresis. The ssDNA is then excised and purified [17]. Biotin-streptavidin separation uses a biotin tagged primer in the PCR amplification process to generate biotinylated dsDNA. The dsDNA can then be captured by streptavidin coated beads. The unbound strand of DNA can be retrieved using sodium hydroxide [18]. Lambda exonuclease can selectively digest a phophorylated strand of the dsDNA in 5' to 3' direction. PCR reactions carried out with a phosphorylated reverse primer can be selectively digested by lambda exonuclease, leaving only the forward strand [19]. Modified primers can be used to create size differences between the forward and reverse strand and be detected by using urea denaturing polyacrylamide gel electrophoresis (PAGE), and subsequently ssDNA can be excised and purified [20].

\subsubsection{Examples of Modified SELEX}

The general process of SELEX has been modified over the past two decades. These modifications mostly focus on increasing the efficiency in separating bound and unbound MREs, increasing specificity of the selected MREs, eliminating the need for immobilizing target molecules, selecting against live whole cells, and decreasing the overall labor intensiveness of the SELEX process. Selected modified SELEX methods pertinent to this review are briefly discussed.

Negative or counter selection is incorporated into the normal SELEX process by introducing negative targets that have structural similarity to the target of interest or are likely to coexist in the target's environment. This modification is to increase the overall specificity of the library during selection, and thus identify MREs that are highly specific to the target. Sooter and co-workers identified a ssDNA MRE target for a herbicide, atrazine, with 2.1-fold higher binding affinity to atrazine than to a closely related herbicide, simazine, by introducing multiple 
negative selection rounds and increasing stringency during the selection [14]. This stringent negative selection scheme was utilized to obtain two other ssDNA MREs that bind to their respective targets with high affinity and specificity $[15,16]$.

Capillary electrophoresis can separate molecules based upon their charges. Target bound and unbound DNA molecules migrate at different rates due to differences in their overall charges, and therefore different species can be separated and collected at different time points. Mendonsa and Bowser were the first to demonstrate using capillary electrophoresis to identify a ssDNA MRE specific for human IgE. Due to its high efficiency in separating different molecules, MREs can generally be identified in 4 to 6 rounds of capillary electrophoresis based SELEX (CESELEX) [21]. CE-SELEX can also select MREs bound to free targets in solution, and without the need of immobilization. A variant of CE-SELEX utilizes non-equilibrium capillary electrophoresis of equilibrium mixtures (NECEEM) to achieve separation (Non-SELEX) has also been developed. In Non-SELEX, repetitive rounds of selection are performed without PCR amplification. Berezovski and co-workers were the first to use Non-SELEX to identify a high affinity MRE ( $\left.\mathrm{K}_{\mathrm{d}}: 0.3 \mathrm{nM}\right)$ specific for hRas protein [22].

$\mathrm{Gu}$ and co-workers developed an immobilization-free SELEX method based upon $\pi-\pi$ stacking interaction between DNA and graphene oxide (GO-SELEX). In GO-SELEX, ssDNA library is adsorbed on graphene oxide and then incubated with the target. In the presence of the target, a portion of the ssDNA library is released from graphene oxide and bind preferentially to the target, while unbound ssDNA remain adsorbed, and can be separated by centrifugation [23]. This method was used to isolate ssDNA MREs specific for bovine viral diarrhea virus type 1 [24]. A high-throughput modification of GO-SELEX was also developed by Gu and co-workers to identify flexible ssDNA MREs that are specific for multiple pesticides with affinities in the 
nanomolar range [25]. Li and co-workers developed a different target immobilization-free SELEX method using a ssDNA library containing a 15-base constant region, sandwiched by two random regions and finally encompassed by two constant primer hybridization regions at both 3' and 5' end [26]. The 15-base constant region can hybridize with biotinylated complementary strand and be captured by streptavidin coated beads. Binding of the ssDNA library to target molecules induces conformational changes and thus releasing the binding-strand from the complementary strand. This method has been adapted to screen for ssDNA MREs specific for multiple pesticides $[27,28]$.

FluMag-SELEX was developed by Stoltenburg and co-workers by immobilizing targets on magnetic beads, and using fluorescently labeled forward primer during PCR amplification [29]. Magnetic separation of bound and unbound MREs are performed similarly to traditional magnetic bead based SELEX. However, the overall binding capacity of the library can be monitor precisely with the presence of fluorescence tag. The selection process can then be terminated when the overall library binding affinity toward the target reaches a plateau. A similar technique has been incorporated in single microbead SELEX described by Tok and Fischer. In their work, only 2 cycles of SELEX were performed to identify multiple ssDNA MREs specific for botulinum neurotoxin with low-micro to nanomolar $K_{d}$ values [30]. The usage of fluorescence tag in the library is further investigated by Veedu and co-workers by performing a one-step selection against alpha-bugarotoxin [31].

Microfluidic chips are also being investigated to facilitate the SELEX process (MSELEX). Microfluidic chips are capable of manipulating a very small amount of immobilized target on magnetic beads, thus achieving a more efficient separation of bound MREs [32]. Soh and co-workers were able to identify ssDNA MREs specific for Botulinum neurotoxin type A 
with low nanomolar binding affinity after only one round of selection [32, 33]. Recently, MREs with nanomolar binding affinity specific for whole influenza A/ H1N1 virus were selected using M-SELEX [34].

Complex targets such as live mammalian and bacteria whole cells have become popular targets for selection. These types of selection are called cell-SELEX or whole cell-SELEX. Early works mostly focused on identifying MREs specific for tumor cells [35-38]. The general methodology of cell-SELEX is very similar to traditional SELEX, but fluorescence-activated cell sorting (FACS) can be utilized to achieve a very high level of separation of MRE bound and unbound cell targets. Multiple pathogenic bacteria gennera, such as Salmonella, Pseudomonas, Staphylococcus, Listeria and Escherichia have been chosen as selection target. The selection and biosening application of ssDNA MREs targeting bacteria, viruses, and associated biomolecules are discussed in the following section.

\subsubsection{Single-stranded DNA MREs Targeting Bacteria}

Single-stranded DNA MREs targeting bacteria can be classified into two general categories, 1) targeting whole cells with known or unknown molecular targets, and 2) targeting pre-defined bacteria cell surface targets or bacteria spores (Table 1.1). 
Table 1.1: Summary table of ssDNA MREs targeting bacteria and bacteria structural components.

\begin{tabular}{llllll}
\hline Target & SELEX & $\mathbf{K}_{\mathbf{d}}$ & Detection Method & LOD & Reference \\
& Method & & & \\
& & & & \\
\hline E. coli K88 & Cell-SELEX & $15 \pm 4 \mathrm{nM}$ & Fluorescence & 1100 & CFU $/ \mathrm{mL}$ \\
& & & & & \\
& & & & - & {$[39]$} \\
E. coli & Cell-SELEX & $12.4 \mathrm{to}$ & - & & \\
& & $25.2 \mathrm{nM}$ & &
\end{tabular}

\begin{tabular}{|c|c|c|c|c|c|}
\hline E. coli NSM59 & Cell- SELEX & $110 \mathrm{nM}$ & - & - & [41] \\
\hline $\begin{array}{l}\text { E.coli K88 } \\
\text { fimbriae protein }\end{array}$ & $\begin{array}{l}\text { Plate } \\
\text { immobilized }\end{array}$ & $25 \pm 4 \mathrm{nM}$ & - & - & [42] \\
\hline $\begin{array}{l}\text { E. coli } 8739 \text { outer } \\
\text { membrane protein }\end{array}$ & $\begin{array}{l}\text { Magnetic } \\
\text { Beads }\end{array}$ & - & FRET & $\begin{array}{l}30 \mathrm{CFU} / \\
\mathrm{mL}\end{array}$ & [43] \\
\hline $\begin{array}{l}\text { E. coli O111:B4 } \\
\text { Lipopolysaccharid } \\
\text { e }\end{array}$ & $\begin{array}{l}\text { Magnetic } \\
\text { Beads }\end{array}$ & - & - & - & [44] \\
\hline $\begin{array}{l}\text { Salmonella } \\
\text { Typhimurium }\end{array}$ & Cell-SELEX & $\begin{array}{l}1.73 \pm 0.54 \\
\mu \mathrm{M}\end{array}$ & Magnetic capture-qPCR & $\begin{array}{l}100-1000 \\
\text { CFU }\end{array}$ & [45] \\
\hline $\begin{array}{l}\text { Salmonella } \\
\text { Typhimurium }\end{array}$ & Cell-SELEX & $\begin{array}{c}6.33 \pm 0.58 \\
\mathrm{nM}\end{array}$ & Fluorescence & $\begin{array}{l}25 \\
\mathrm{CFU} / \mathrm{mL}\end{array}$ & [46] \\
\hline $\begin{array}{l}\text { Salmonella } \\
\text { Typhimurium }\end{array}$ & Cell-SELEX & - & 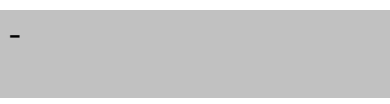 & - & [47] \\
\hline $\begin{array}{l}\text { Salmonella } \\
\text { Typhimurium } \\
\text { outer membrane } \\
\text { protein }\end{array}$ & $\begin{array}{l}\text { Nitrocellulos } \\
\text { e membrane }\end{array}$ & - & $\begin{array}{l}\text { Magnetic capture-qPCR } \\
\text { (spike and recovery) }\end{array}$ & $\begin{array}{l}<10 \\
\text { CFU/g }\end{array}$ & [48] \\
\hline $\begin{array}{l}\text { Salmonellae } \\
\text { typhimurium/ } \\
\text { enteritidis }\end{array}$ & Cell-SELEX & $\begin{array}{l}\text { nanomolar } \\
\text { to } \\
\text { micromola } \\
\text { r range }\end{array}$ & - & - & [49] \\
\hline $\begin{array}{l}\text { Salmonellae } \\
\text { enteritidis/ }\end{array}$ & Cell-SELEX & $\begin{array}{l}7 \mathrm{nM}, 25 \\
\mathrm{nM}\end{array}$ & - & - & [50] \\
\hline
\end{tabular}




\begin{tabular}{|c|c|c|c|c|c|}
\hline typhimurium & & & & & \\
\hline $\begin{array}{l}\text { Salmonella } \\
\text { Paratyphi A }\end{array}$ & Cell-SELEX & $47 \pm 3 n M$ & Chemoluminescence & $\begin{array}{l}1000 \\
\mathrm{CFU} / \mathrm{mL}\end{array}$ & [51] \\
\hline Salmonella 08 & Cell-SELEX & $32.04 \mathrm{nM}$ & - & - & {$[52]$} \\
\hline Vibrio alginolyticus & Cell-SELEX & $\begin{array}{l}27.5 \pm 9.2 \\
\mathrm{nM}\end{array}$ & PCR & $\begin{array}{l}100 \\
\mathrm{CFU} / \mathrm{mL}\end{array}$ & {$[53]$} \\
\hline $\begin{array}{l}\text { Vibrio } \\
\text { parahemolyticus }\end{array}$ & Cell-SELEX & $\begin{array}{l}16.88 \pm \\
1.92 \mathrm{nM}\end{array}$ & - & - & [54] \\
\hline $\begin{array}{l}\text { Listeria } \\
\text { monocytogenes }\end{array}$ & Cell-SELEX & $\begin{array}{l}\text { Mid } \\
\text { nanomolar } \\
\text { range }\end{array}$ & 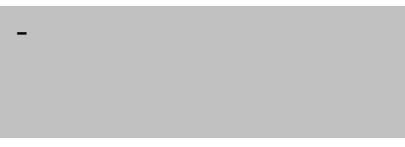 & 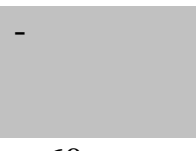 & [55] \\
\hline $\begin{array}{l}\text { Listeria } \\
\text { monocytogenes }\end{array}$ & Cell-SELEX & $\begin{array}{l}35.7 \pm 8.02 \\
\mathrm{uM}\end{array}$ & Magnetic capture-qPCR & $\begin{array}{l}<60 \\
\text { CFU/500 } \\
\mu \mathrm{L}\end{array}$ & [56] \\
\hline $\begin{array}{l}\text { Listeria } \\
\text { monocytogenes }\end{array}$ & Cell-SELEX & $60.01 \mathrm{nM}$ & Fluorescence & - & [57] \\
\hline $\begin{array}{l}\text { Listeria } \\
\text { monocytogenes }\end{array}$ & Cell-SELEX & $\begin{array}{l}48.74 \pm \\
3.11 \mathrm{nM}\end{array}$ & Fluorescence & $\begin{array}{l}75 \\
\mathrm{CFU} / \mathrm{mL}\end{array}$ & [58] \\
\hline $\begin{array}{l}\text { Listeria } \\
\text { monocytogenes } \\
\text { Internalin A }\end{array}$ & Filter plate & - & Fiber-optic & $\begin{array}{l}1000 \\
\mathrm{CFU} / \mathrm{mL}\end{array}$ & [59] \\
\hline $\begin{array}{l}\text { Shigella } \\
\text { dysenteriae }\end{array}$ & Cell-SELEX & $\begin{array}{l}23.47 \pm \\
2.48 \mathrm{nM}\end{array}$ & Fluorescence & $\begin{array}{l}50 \\
\mathrm{CFU} / \mathrm{mL}\end{array}$ & [60] \\
\hline $\begin{array}{l}\text { Streptococcus } \\
\text { mutans }\end{array}$ & Cell-SELEX & $33 \mathrm{nM}$ & $\begin{array}{l}\text { Colorimetric (Flow } \\
\text { through) }\end{array}$ & $\begin{array}{l}10^{5}-10^{8} \\
\mathrm{CFU} / \mathrm{mL}\end{array}$ & [61] \\
\hline $\begin{array}{l}\text { Streptococcus } \\
\text { pyogenes }\end{array}$ & Cell-SELEX & $9,10 \mathrm{nM}$ & - & - & [62] \\
\hline $\begin{array}{l}\text { Staphylococcus } \\
\text { aureus }\end{array}$ & Cell-SELEX & $\begin{array}{l}35,129 \\
n M\end{array}$ & Optical Light scattering & $1 \mathrm{CFU} / \mathrm{mL}$ & [63] \\
\hline $\begin{array}{l}\text { Staphylococcus } \\
\text { aureus }\end{array}$ & Cell-SELEX & $\begin{array}{l}\text { nanomolar } \\
\text { range }\end{array}$ & - & - & [64] \\
\hline Proteus mirabilis & Cell-SELEX & $\begin{array}{l}7.7 \mathrm{nM} \\
4.1 \mathrm{nM}\end{array}$ & - & - & [65] \\
\hline $\begin{array}{l}\text { Pseudomonas } \\
\text { aeruginosa }\end{array}$ & Cell-SELEX & $\begin{array}{l}\text { Low } \\
\text { nanomolar } \\
\text { range }\end{array}$ & Fluorescence & - & [66] \\
\hline $\begin{array}{l}\text { Mycobacterium } \\
\text { tuberculosis }\end{array}$ & Cell-SELEX & $\begin{array}{l}\mathrm{K}_{\mathrm{a}} 10^{5}- \\
10^{6} \mathrm{M}\end{array}$ & - & - & [67] \\
\hline $\begin{array}{l}\text { Francisella } \\
\text { tularensis }\end{array}$ & Cell SELEX & - & ALISA & $\begin{array}{l}1700 \\
\text { bacteria/m }\end{array}$ & [68] \\
\hline
\end{tabular}




\begin{tabular}{|c|c|c|c|c|c|}
\hline $\begin{array}{l}\text { subspecies (subsp) } \\
\text { japonica bacterial } \\
\text { antigen }\end{array}$ & & & & $\bar{L}$ & \\
\hline $\begin{array}{l}\text { Bacillus anthracis } \\
\text { spores/ anthrose } \\
\text { sugar }\end{array}$ & $\begin{array}{l}\text { Magnetic } \\
\text { beads }\end{array}$ & - & & $\begin{array}{l}30,000 \\
\text { spores/ml }\end{array}$ & [69] \\
\hline $\begin{array}{l}\text { Bacillus anthracis } \\
\text { spores }\end{array}$ & $\begin{array}{l}\text { Magnetic } \\
\text { beads }\end{array}$ & - & $\begin{array}{l}\text { Magnetic bead- } \\
\text { electrochemiluminescen } \\
\text { ce }\end{array}$ & $\begin{array}{l}10-6 \times 10^{6} \\
\text { spores }\end{array}$ & {$[70]$} \\
\hline $\begin{array}{l}\text { Bacillus } \\
\text { thuringiensis } \\
\text { spores }\end{array}$ & $\begin{array}{l}\text { Magnetic } \\
\text { Beads }\end{array}$ & - & Fluorescence & $\begin{array}{l}1000 \\
\mathrm{CFU} / \mathrm{mL}\end{array}$ & [71] \\
\hline $\begin{array}{l}\text { Campylobacter } \\
\text { jejuni }\end{array}$ & Cell SELEX & $\begin{array}{l}292.8 \pm \\
53.1 \mathrm{nM}\end{array}$ & - & - & [72] \\
\hline $\begin{array}{l}\text { Campylobacter } \\
\text { jejuni (surface } \\
\text { protein) }\end{array}$ & $\begin{array}{l}\text { Magnetic } \\
\text { Beads }\end{array}$ & - & $\begin{array}{l}\text { Fluorescence (Magnetic } \\
\text { bead/ Quantum dot) }\end{array}$ & $\begin{array}{l}10-250 \\
\text { CFU in } \\
\text { food } \\
\text { matrix, } 2.5 \\
\text { CFU in } \\
\text { buffer }\end{array}$ & [73] \\
\hline $\begin{array}{l}\text { Campylobacter } \\
\text { jejuni (killed) }\end{array}$ & CE-SELEX & - & $\begin{array}{l}\text { Capillary } \\
\text { Electrophoresis }\end{array}$ & $\begin{array}{l}6.4 \times 10^{6} \\
\text { cells } / \mathrm{mL}\end{array}$ & [74] \\
\hline Peptidoglycan & Filter & $\begin{array}{l}0.415 \pm \\
0.047 \mu \mathrm{M} / \\
1.261 \pm \\
0.280 \mu \mathrm{M}\end{array}$ & - & - & [75] \\
\hline $\begin{array}{l}\text { Lipopolysaccharid } \\
\text { e (endotoxin) }\end{array}$ & $\begin{array}{l}\text { NECEEM } \\
\text { non-SELEX }\end{array}$ & $\begin{array}{l}\text { low to high } \\
\text { nanomolar } \\
\text { range }\end{array}$ & Electrochemical & $\begin{array}{l}0.01-1 \\
\mathrm{ng} / \mathrm{mL}\end{array}$ & {$[76]$} \\
\hline
\end{tabular}

Multiple virulent strains of the gram-negative bacteria, Escherichia coli, have been chosen as targets for the selection of specific ssDNA MREs due to their enterotoxigenic effects and the potential of contaminating food and water [77]. Peng et al. enriched a ssDNA MRE library specific for E.coli K88 whole bacteria [39]. They also developed a sandwich detection system, in which biotinylated antibodies targeting the K88 strain were immobilized on magnetic beads as the capturing element and the 5' FITC labeled ssDNA library from Round 13 selection served as the reporter in a fluorescent assay. A lower limit of detection (LOD) of $1100 \mathrm{CFU} / \mathrm{mL}$ was achieved in pure culture. Artificial contaminated fecal samples were also tested with a LOD 
of 2200 CFU per gram. However, no individual ssDNA MREs were able to achieve the same degree of binding affinity as the whole library and a ssDNA MRE with high affinity and specificity against K88 fimbriae protein was selected after eleven rounds [42]. A fluorescence binding assay was used to obtain the affinity of selected MRE candidates. The reported equilibrium dissociation constant $\left(\mathrm{K}_{\mathrm{d}}\right)$ for the best candidate MRE was $25 \pm 4 \mathrm{nM}$. Kim et al. performed ten rounds of selection against a fecal strain of $E$. coli along with multiple negative selections against other species of bacteria. They identified four candidate sequences with high affinity for the target strain. All four candidates were highly selective against negative target bacteria. However, they all showed cross binding activity with other strains of E.coli. This suggested that the selected candidates potentially bound to common antigens expressed in multiple strains of E. coli [40]. Savory et al. identified a ssDNA MRE with high specificity and affinity $\left(\mathrm{K}_{\mathrm{d}}=110 \mathrm{nM}\right)$ for an uropathogenic strain of E. coli. Quantitative PCR was used to monitor the SELEX process in order to minimize the number of rounds of SELEX required. After five rounds of SELEX, a selected ssDNA MRE containing a guanine-quadruplex sequence motif showed low cross binding activities toward other strains of E. coli [41]. In addition to selecting whole E. coli bacteria as targets, outer membrane protein from E. coli 8739 (Crook's strain), and lipopolysaccharide from O111:B4 strains were also chosen as targets for selection. A fluorescence resonance energy transfer (FRET) assay was developed to detect $E$. coli 8379 with a LOD of $30 \mathrm{CFU} / \mathrm{mL}$ [43]. The ssDNA MRE targeting lipopolysaccharide showed antibacterial effects on both O111:B4 and K12 strains [44]. However, $\mathrm{K}_{\mathrm{d}}$ values were not reported in either study.

Several ssDNA MREs have been selected against species of foodborne bacteria including Salmonella, Listeria, and Vibrio. Dwivedi et al. identified a ssDNA MRE specific for whole cell 
Salmonella enterica serovar Typhimurium with a reported $\mathrm{K}_{\mathrm{d}}$ of $1.73 \pm 0.54 \mu \mathrm{M}$ after eight rounds of selection [45]. Two rounds of negative selection against a mixture of non-target bacteria were also performed to enhance the selectivity of the library. A detection application was developed using immobilized biotinylated MREs on streptavidin coated magnetic beads as the capturing elements, and was coupled with quantitative PCR. The reported LOD of this assay was between 100 to $1000 \mathrm{CFU}$ in a $290 \mu \mathrm{L}$ sample volume. Duan et al. performed a similar selection on the same organism with nine rounds of target selection, and two rounds of negative selection against mixtures of non-target bacteria [46]. The best candidate ssDNA MRE had a $\mathrm{K}_{\mathrm{d}}$ value of $6.33 \pm 0.58 \mathrm{nM}$ and high specificity based upon flow cytometry analysis. A fluorescence bioassay achieved a LOD of $25 \mathrm{CFU} / \mathrm{mL}$. Another similar study performed by Moon et al. showed relatively high affinities and specificities of selected candidate sequences after ten rounds of target and six rounds of negative selections. However, no $K_{d}$ values were reported in the study [47]. Outer membrane proteins of Salmonella enterica serovar Typhimurium were chosen as selection target by Joshi et al. In that study seven rounds of selection were performed with three rounds of negative selection against E. coli outer membrane proteins and lipopolysaccharides. A magnetic bead based quantitative real-time PCR assay was developed using immobilized ssDNA MRE as the capturing element. Food and environmental samples were tested to demonstrate the translational usage of the assay. A LOD of less than $10 \mathrm{CFU}$ per gram of artificially contaminated bovine feces was reported. Additionally, 10 to 100 of CFU were detected in $9 \mathrm{~mL}$ of artificially contaminated whole carcass chicken rinse sample solution in a pull-down assay [48]. Two recent studies identified ssDNA MREs specific for two serovars of Salmonella, Typhimurium and Enteritidis [49, 50]. Park et al. truncated out the random region (29 to 30-mer) of selected candidates and identified three ssDNA MREs with $K_{d}$ values in 
micromolar range toward their respective serovars after ten rounds of mixed target and counter target selection. Poly-D-lysine was conjugated to the selected MREs, and achieved an approximately 20 to 100-fold enhancement in their binding affinities [49]. Kalovskaya et al. also performed a similar selection on the two serovars of Salmonella [50]. After twelve rounds of selection, two ssDNA MREs with $K_{d}$ values ranges in nanomolar were identified (Enteritidis: $K_{d}$ $=7 \mathrm{nM}$; Typhimurium: $\mathrm{K}_{\mathrm{d}}=25 \mathrm{nM}$ ). Both selected MREs were able to demonstrate $\mathrm{a}$ bacteriastatic effect in their respective bacterial cultures. An antibiotic-resistant serovar of Salmonella enterica, Paratyphi A was chosen as target by Yang et al. A total of thirteen positive rounds and four negative rounds of selection were performed to identify a MRE with high affinity $\left(\mathrm{K}_{\mathrm{d}}=47 \pm 3 \mathrm{nM}\right)$ and specificity toward Paratyphi A. A LOD of $1000 \mathrm{CFU} / \mathrm{mL}$ was achieved using chemoluminescence assay based on self-assembled single-walled carbon nanotubes and DNAzymes-labeled MRE as detection elements [51]. A MRE with high specificity toward Salmonella O8 was identified by Liu et al. after eleven rounds of positive and two rounds of negative selection. The selected MRE had a reported $K_{d}$ value of $32.04 \mathrm{nM}$. A preliminary fluorescent in situ labeling assay was developed with the MRE. However, no LOD was reported [52].

Consumption of uncooked or undercooked seafood contaminated by Vibrio bacteria can lead to food poisoning [78]. Two different species, Vibrio parahemolyticus and Vibrio alginolyticus were chosen as selection targets. Nine rounds of cell-SELEX using flow cytometry were carried out to identify a ssDNA MRE with high affinity and specificity for Vibrio parahemolyticus $\left(\mathrm{K}_{\mathrm{d}}=16.88 \pm 1.92 \mathrm{nM}\right)[53,54]$. Tang et al. performed fifteen rounds of cellSELEX on inactivated Vibrio alginolyticus. Negative selection was performed every third positive target round to improve the library specificity. The study did not characterize affinities 
and specificities of candidate ssDNA MREs from the last round of selection. Instead, the whole library was characterized to have a $K_{d}$ value of $27.5 \pm 9.2 \mathrm{nM}$ and was highly specific toward the target. The enriched library was able to detect $100 \mathrm{CFU} / \mathrm{mL}$ of the bacteria based on a PCR amplification assay [53].

Listeria monocytogenes is a foodborne gram-positive bacterium that can cause serious illnesses and even death. FDA and European Union both have zero tolerance of $L$. monocytogenes in ready-to-eat food products. Suh et al. conducted two studies to identify ssDNA MREs specific for $L$. monocytogenes $[55,56]$. In their earlier study, a MRE with a micromolar $K_{d}$ value was identified after six rounds of positive and two rounds of negative selections. The MRE showed low cross binding to negative target bacteria, but had similar binding affinity for other members of the Listeria genus. A magnetic bead based capture assay coupled with quantitative PCR was developed. The assay was able to detect less than 60 CFU in $500 \mu \mathrm{L}$ of binding buffer containing a mixture of non-Listeria bacteria [56]. In their later study, the affinities of selected candidate MREs were improved with reported values of $K_{d}$ in the nanomolar range and were specific for the target bacteria at different growth phases [55]. Duan et al. performed similar whole cell in vitro selection on L. monocytogenes. The selected MRE had high affinity $\left(\mathrm{K}_{\mathrm{d}}=48.74 \pm 3.11 \mathrm{nM}\right)$ and was highly specific toward the target. A fluorescent cross binding assay showed significantly lower binding activities toward negative bacteria targets and as well as other bacteria species in the Listeria genus. A sandwich fluorescent bioassay was developed and demonstrated a LOD of $75 \mathrm{CFU} / \mathrm{mL}$ [58]. Most recently, Liu et al. performed eight rounds of selection to identify ssDNA MREs specific for $L$. monoceytogenes. The best candidate MRE reported to have a $\mathrm{K}_{\mathrm{d}}$ value of $60.01 \mathrm{nM}$ and had high specificity. A fluorescent based detection assay was developed to enable the observation of 
binding between the MRE and target bacteria using fluorescent microscope, but the LOD was not reported [57].

Ohk et al. selected a ssDNA MRE specific for internalin A of L. monocytogenes. Internalin A is a major invasion protein expressed on the cell surface of L. monocytogenes [79]. A highly specific sandwich style fiber-optic biosensor was developed by using the selected MRE and antibody. A reported LOD of $1000 \mathrm{CFU} / \mathrm{mL}$ was achieved. The sensor also successfully detected the bacteria in artificially contaminated ready-to-eat meat products. However, affinity data was not reported in the study [59].

Shigella dysenteriae is a gram negative bacterium that causes severe epidemic diarrhea in many countries [80]. Duan et al. used cell-SELEX methodology to identify ssDNA MRE specific for $S$. dysenteriae $[46,54,58,60]$. The best candidate MRE had a reported $\mathrm{K}_{\mathrm{d}}$ value of $23.47 \pm 2.48 \mathrm{nM}$ and low cross binding activities toward negative bacteria targets. A fluorescent based detection assay demonstrated a LOD of 50 CFU/mL [60]

Campylobacter jejuni is a highly infectious gram negative bacterium that is one of the leading causes of acute diarrheal sickness worldwide [81]. Bruno et al. performed an in vitro selection by extracting surface proteins of $C$. jejuni and immobilizing them on magnetic beads. No values of $K_{d}$ were reported in the study. However, a fluorescent assay based on magnetic beads and quantum dot was developed to detect the bacteria in different food matrices. The assay showed low cross binding activities with other species of bacteria, but was not able to distinguish between bacteria in the Campylobacter genus. The reported LODs were 2.5 CFU and 10 to 250 CFU in buffer solution and in different food matrices respectively [73]. CE-SELEX was employed by Stratis-Cullum et al. to identify MREs specific for C. jejuni. Killed bacteria were used as target in their study. A qualitative capillary electrophoresis immunoassay was developed 
with a LOD of $6.3 \times 10^{6}$ cells/mL [74]. Dwivede et al. performed cell-SELEX on live C. jejuni. A total of ten positive rounds and two negative rounds were carried out to identify ssDNA MREs with high affinity and specificity toward the target bacteria $\left(\mathrm{K}_{\mathrm{d}}=292.8 \pm 53.1 \mathrm{nM}\right)[72]$.

Bacteria that are associated with common infectious diseases, such as Streptococcus, Staphylococcus and Pseudomonas, are also popular targets for in vitro selection. Identification of MREs targeting infectious bacteria could potentially be used to facilitate diagnosis and thus decreasing the time between culture collections to specific antibiotic treatment.

Savory et al. performed cell-SELEX on Proteus mirabilis, a common cause of catheter associated urinary tract infections in long-term catheterized patients. MREs specific for two different strains of $P$. mirabilis with low nanomolar range $K_{d}$ values were identified after 6 rounds of in vitro selection. Additionally, an in silico maturation (ISM) process was performed to increase the specificity of the selected MRE. It was reported that a 36\% higher specificity was achieved after the ISM process [65]. This same technique was again employed to select MRE specific for Streptococcus mutants, the main causative pathogen of dental caries. The affinity of the identified MRE was improved up to 16-fold and the specificity was increased 12-fold after ISM. A gold colloids based colorimetric flow through assay was developed and demonstrated the detection $S$. mutants in the ranges of $10^{5}-10^{8} \mathrm{CFU} / \mathrm{mL}$ [61].

Streptococcus pyogenes (Group A Streptococcus) is often the causative pathogen of a wide range of infectious diseases, such as streptococcal pharyngitis, and streptococcal toxic shock syndromes [82]. Different M-types of live S. pyogenes were chosen for selection by Hamula et al. After 20 rounds of target selection, the two best candidate MREs yielded high affinity for Group A Streptococcus $\left(\mathrm{K}_{\mathrm{d}}=9-10 \mathrm{nM}\right)$. It was noteworthy that the candidate MREs showed good specificities, even though the authors did not perform any negative selections [62]. 
Strapylococcus aureus is a gram-positive bacteria associated with numerous of infections in human [83]. Cao et al. selected a panel of ssDNA MREs specific for S. aureus after several rounds of target and counter target selection. The reported $\mathrm{K}_{\mathrm{d}}$ values of individual candidate MREs were in the nanomolar range with high specificity. The study showed that the combination of the panel of MREs yielded a better sensitivity in recognizing S. aureus than any single MRE [64]. Change et al. selected two ssDNA MREs with high affinities and specific toward S. aureus $\left(\mathrm{K}_{\mathrm{d}}=35\right.$ and $\left.129 \mathrm{nM}\right)$. The reported values of $\mathrm{K}_{\mathrm{d}}$ improved to 3.03 and $9.9 \mathrm{nM}$ respectively after thiol-modification and conjugation to gold nanoparticles. Subsequently, the MRE conjugated gold nanoparticles were utilized to capture target bacteria, and a resonance lightscattering signal demonstrated the detection of single S. aureus cell in 1.5 hours [63].

Pseudomonas aeruginosa is a gram-negative bacterium that is commonly associated with nosocomial infections [84, 85]. Wang et al. performed fifteen rounds of positive and two rounds of counter target selection to identify ssDNA MREs with $\mathrm{K}_{\mathrm{d}}$ values in the low nanaomolar range. The selected MRE showed negligible binding to counter bacteria cell targets. A fluorescence in situ hybridization (FISH) assay was developed to show rapid detection of P. aeruginosa. However, the detection ranges were not reported [66].

Mycobacterium tuberculosis is the etiologic pathogen for tuberculosis [86]. Chen et al. reported a ssDNA MRE with an apparent association constant $\left(\mathrm{K}_{\mathrm{a}}\right)$ between $10^{5}-10^{6} \mathrm{M}$ and was highly specific. The authors reported an antibacterial effect of the selected MRE with both in vitro and in vivo models [67].

Highly infectious bacteria and bacteria spores have been considered as potential biological warfare agents, and it is important to detect these biological threats rapidly [87]. Bruno et al. 1999 performed an in vitro selection of ssDNA MREs targeting Bacillus anthracis 
spores, the causative agent of anthrax. Autoclaved anthrax spores were used in the selection. A MRE-magnetic bead electrochemiluminescence sandwich assay was developed with a reported detection range of $10-10^{6}$ spores [70]. Ikanovic et al. performed a selection of ssDNA MREs specific for Bacillus thuringiensis spores, a closely related species to B. anthracis. In this study, the methodology was adopted from Bruno et al. 1999. A fluorescent assay based on cadmium selenide quantum dots was developed with a reported detection limit at about $1000 \mathrm{CFU} / \mathrm{mL}$ [71]. Bruno et al. 2012 revisited the selection of Bacillus spores. In this later study, anthrose sugar on anthrax spores was chosen as target for selection. A MRE beacon based on fluorescent signals was developed and generated strong signal at spore concentrations greater than 30,000 spores/mL. The authors also compared the MRE sequences pattern to previous studies and identified similarities in sequences composed of T/G rich bases. It was also reported that MREs specific for whole spores did not generate fluorescent signals in the presence of anthrose sugar, suggesting that the selected spore specific MREs possibly bound to a different eptiope and warranting further research [69].

Francisella tularensisis is an encapsulated, gram-negative coccobacillus that is highly infectious. Reports show as few as 25 organisms in aerosol can cause diseases [88]. Vivekananda et al. performed ten rounds of selection on Francisella tularensisis subspecies japonica bacterial antigen. A cocktail of 25 ssDNA MREs was reported to have high specificity toward the target bacteria. A MRE modified enzyme-linked immunosorbent assay was developed, and demonstrated binding to the target and other subspecies of $F$. tularensisis but not to other species of bacteria and chicken lysozyme or chicken albumin. In addition, the assay was able to achieve better sensitivity then traditional ELISA using anti-tularemia antiserum and anti-tularemia polycolonal antibodies. The reported LOD was 1700 bacteria/mL [68]. 
Peptidoglycan is a macromolecule universally expressed on bacteria outer cell wall [89]. Ferreira et al. identified two ssDNA MREs with sub to low micromolar $\mathrm{K}_{\mathrm{d}}$ values that can bind specifically to both gram-positive and gram-negative bacteria. Neither MRE bounded to human fibroblasts or Candida albicans, and could potentially be used as generic detection elements for bacteria [75].

Lipopolysaccharide (LPS or endotoxin) is expressed in the outer membrane of gramnegative bacteria, and can illicit strong immune response upon entering into mammalian cells. [90, 91] Kim et al. used nonequilibrium capillary electrophoresis of equilibrium mixtures (NECEEM) based non-SELEX to identify multiple ssDNA MREs with high affinities toward lipopolysaccharide in only three rounds of selection. Selected MREs also demonstrated very low cross binding activities to bovine serum albumin, and other intracellular molecules, such as DNA, RNA, glucose and sucrose in an electrochemical assay. This assay resulted in a target detection ranges of 0.01 to $1 \mathrm{ng} / \mathrm{mL}[76]$

\subsubsection{Single-stranded DNA MREs Targeting Viruses}

There is a wealth of literature describing ssDNA MREs targeting various virus life cycle regulator proteins with the purpose of therapeutic application. In contrast, there is a lesser amount of research on ssDNA MREs for virus biosensing application (Table 1.2).

Table 1.2: Summary table of ssDNA MREs targeting viruses and virus protein for biosensing applications.

\begin{tabular}{|c|c|c|c|c|c|}
\hline \multirow[t]{2}{*}{ Target } & SELEX & Kd & Detection & LOD & Reference \\
\hline & Method & & Method & & \\
\hline
\end{tabular}




\begin{tabular}{|c|c|c|c|c|c|}
\hline $\begin{array}{l}\text { Human } \\
\text { Noroviruses }\end{array}$ & $\begin{array}{l}\text { Antibody-bead } \\
\text { conjugates }\end{array}$ & $\begin{array}{l}\text { High nanomolar } \\
\text { range }\end{array}$ & RT-qPCR & $\begin{array}{l}10 \text { RNA } \\
\text { copies }\end{array}$ & [92] \\
\hline Norovirus & $\begin{array}{l}\text { Nitrocellulose } \\
\text { membrane }\end{array}$ & $\begin{array}{l}\text { Low picomolar } \\
\text { range }\end{array}$ & Electrochemical & $\begin{array}{l}180 \text { virus } \\
\text { particles }\end{array}$ & [93] \\
\hline $\begin{array}{l}\text { Norovirus II.4 } \\
\text { capsid protein } \\
\text { VP1 }\end{array}$ & Filter & - & - & - & [94] \\
\hline $\begin{array}{l}\text { Influenza A } \\
\text { H1N1 }\end{array}$ & $\begin{array}{l}\text { Microfluidic } \\
\text { SELEX }\end{array}$ & $\begin{array}{l}55.14 \pm 22.40 \\
n M\end{array}$ & Bead/ Fluorescent & $\begin{array}{l}6.4 \times 10-3 \\
\text { HAU }\end{array}$ & [34] \\
\hline $\begin{array}{l}\text { Avian } \\
\text { influenza } \\
\text { H5N1 }\end{array}$ & $\begin{array}{l}\text { Nitrocellulose } \\
\text { membrane }\end{array}$ & $4.65 \mathrm{nM}$ & Dot Blot & $1.28 \mathrm{HAU}$ & [95] \\
\hline $\begin{array}{l}\text { Influenza A } \\
\text { hemagglutinin } \\
\text { protein }\end{array}$ & $\begin{array}{l}\text { TALON } \\
\text { affinity resin }\end{array}$ & $\begin{array}{l}\text { Low nanomolar } \\
\text { range }\end{array}$ & Sandwich ELAA & - & [96] \\
\hline $\begin{array}{l}\text { SARS-CoV N } \\
\text { protein }\end{array}$ & Ni-NTA beads & $4.93 \pm 0.3 \mathrm{nM}$ & Western Blot & - & [10] \\
\hline $\begin{array}{l}\text { Bovine viral } \\
\text { diarrhea virus }\end{array}$ & GO-SELEX & $\begin{array}{l}5 \times 10^{4} \\
\text { TCID50/ml }\end{array}$ & $\begin{array}{l}\text { SPR AuNP } \\
\text { sandwich }\end{array}$ & $\begin{array}{l}800 \\
\text { copies/mL }\end{array}$ & [24] \\
\hline $\begin{array}{l}\text { HCV envelope } \\
\text { surface } \\
\text { glycoprotein } \\
\text { E2 }\end{array}$ & $\begin{array}{l}\text { Cell surface } \\
\text { SELEX }\end{array}$ & $1.05 \pm 1 \mathrm{nM}$ & - & - & [97] \\
\hline $\begin{array}{l}\text { Dengue Virus } \\
\text { Type-2 } \\
\text { envelope } \\
\text { protein } \\
\text { domain III }\end{array}$ & $\begin{array}{l}\text { Ni-NTA } \\
\text { magnetic beads }\end{array}$ & $154 \pm 40 \mathrm{nM}$ & - & - & [98] \\
\hline $\begin{array}{l}\text { HIV reverse } \\
\text { transcriptase }\end{array}$ & CE-SELEX & $180 \pm 70 \mathrm{pM}$ & - & - & [99] \\
\hline
\end{tabular}

For the focus of this review, those MREs with therapeutic applications are listed in the following table without further detail discussions (Table 1.3).

Table 1.3: Summary table of ssDNA MREs targeting viruses and virus proteins for therapeutic applications.

\begin{tabular}{lllll}
\hline Virus & Target & SELEX Method & $\mathbf{K}_{\mathbf{d}}$ & Reference \\
\hline HIV & $\begin{array}{l}\text { Reverse } \\
\text { transcriptase }\end{array}$ & Nitrocellulose Filters & - & {$[100]$} \\
HIV & $\begin{array}{l}\text { Reverse } \\
\text { transcriptase }\end{array}$ & Sephadex columns & $660 \mathrm{pM}$ & {$[101]$} \\
HIV & Reverse & Nitrocellulose Filters & $1 \mathrm{nM}$ & {$[102]$} \\
\hline
\end{tabular}




\begin{tabular}{|c|c|c|c|c|}
\hline & transcriptase & & & \\
\hline HIV & $\begin{array}{l}\text { Reverse } \\
\text { transcriptase }\end{array}$ & Primer-free SELEX & $82 \mathrm{nM}$ & [103] \\
\hline HIV & Integrase & Nitrocellulose Filters & - & [104] \\
\hline HIV & Integrase & - & - & [105] \\
\hline HIV & $\begin{array}{l}\text { Trans- } \\
\text { activation- } \\
\text { responsive RNA } \\
\text { element (TAR) }\end{array}$ & Magnetic beads & $20 \mathrm{nM}$ & [106] \\
\hline HIV & $\begin{array}{l}\text { Trans- } \\
\text { activation- } \\
\text { responsive RNA } \\
\text { element (TAR) }\end{array}$ & Magnetic beads & $50 \mathrm{nM}$ & [107] \\
\hline $\mathrm{HCV}$ & $\begin{array}{l}\text { NS5B RNA } \\
\text { polymerase }\end{array}$ & Nitrocellulose Filters & $132 \mathrm{nM}$ & [108] \\
\hline HBV & Core Protein & - & $\begin{array}{l}\text { High affinity determined } \\
\text { by dot blot }\end{array}$ & [109] \\
\hline $\begin{array}{l}\text { SARS } \\
\text { coronavirus }\end{array}$ & Helicase & Magnetic beads & $5 \mathrm{nM}$ & [110] \\
\hline $\begin{array}{l}\text { Influenza A } \\
\text { virus }\end{array}$ & $\begin{array}{l}\text { Hemagglutinin } \\
\text { from H3N2 }\end{array}$ & Ni-NTA beads & - & [111] \\
\hline $\begin{array}{l}\text { Influenza A } \\
\text { virus }\end{array}$ & $\begin{array}{l}\text { Hemagglutinin } \\
\text { from H5N1 }\end{array}$ & Ni-NTA beads & $\begin{array}{l}\text { High affinity determined } \\
\text { by ELISA }\end{array}$ & [112] \\
\hline $\begin{array}{l}\text { Influenza A } \\
\text { virus }\end{array}$ & $\begin{array}{l}\text { Hemagglutinin } \\
\text { from H3N2 }\end{array}$ & Ni-NTA magnetic beads & $7 \mathrm{nM}$ & [113] \\
\hline $\begin{array}{l}\text { Influenza A } \\
\text { virus }\end{array}$ & $\begin{array}{l}\text { Hemagglutinin } \\
\text { from H9N2 }\end{array}$ & Nitrocellulose Filters & $\begin{array}{l}\text { High affinity determined } \\
\text { by ELISA }\end{array}$ & [114] \\
\hline $\begin{array}{l}\text { Influenza A } \\
\text { virus }\end{array}$ & $\begin{array}{l}\text { Non-structural } \\
\text { protein } 1\end{array}$ & $\begin{array}{l}\text { Glutathione agarose } \\
\text { beads }\end{array}$ & $18.91 \pm 3.95 \mathrm{nM}$ & [115] \\
\hline Rabies Virus & $\begin{array}{l}\text { Rabies virus } \\
\text { infected BHK- } \\
21 \text { cells }\end{array}$ & Cell SELEX & $28 \mathrm{nM}$ & [116] \\
\hline HPV & $\begin{array}{l}\text { HPV } \\
\text { transformed } \\
\text { HeLa cells }\end{array}$ & Cell SELEX & $1 \mathrm{nM}$ & [117] \\
\hline $\begin{array}{l}\text { Vaccinia } \\
\text { Virus }\end{array}$ & $\begin{array}{l}\text { Whole virus } \\
\text { particle }\end{array}$ & One-step MonoLEX & $\begin{array}{l}\text { High affinity determined } \\
\text { by dot blot, SPR, etc }\end{array}$ & [118] \\
\hline
\end{tabular}

In recent years, there has been an increase in the interest in the application of ssDNA MREs for virus detection. Human noroviruses are the leading cause of acute gastroenteritis worldwide. Current detection methods for the virus are time consuming and labor intensive [119]. Giamberardino et al. performed nine rounds of in vitro selection on murine norovirus. The best candidate MRE was reported to have affinity in the low picomolar range. It displayed cross 
binding activity with human norovirus, but not to a structurally similar virus, feline calicivirus. An electrochemical sensor using a gold nanoparticle modified screen-printed carbon electrode was developed with a reported LOD of 180 virus particles [93]. Escudero-Abarca et al. performed selection on multiple strains of human noroviruses, including Snow Mountain virus, and Norwalk virus. Candidate MREs showed high binding affinities that were comparable to commercially available antibodies. The best MRE was also able to show binding to specific virus strains in human fecal samples. A reported LOD of 10 virus RNA copies was achieved in artificially contaminated lettuce by using immobilized biotinylated MRE on streptavidin magnetic beads coupled with real-time quantitative PCR [92]. The capsid protein VP1 of Norovirus genotype II.4 was chosen to be the target for selection by Beier et al. After twelve rounds of selection, surface plasmon resonance analysis was used to show the high specificity of the selected MRE. Computer simulation was used to characterize the binding interaction between VP1 and candidate MREs. However the authors did not report the $K_{d}$ value in the study [94].

Influenza virus is the causative agent for many upper respiratory diseases and can potentially cause pandemics with high mobility and mortality [120]. Lai et al. used M-SELEX to identify ssDNA MRE target influenza A H1N1 with high affinity $\left(K_{d}=55.14 \pm 22.40 \mathrm{nM}\right)$. A magnetic bead based florescent assay achieved a reported LOD of $6.4 \times 10^{-3}$ HAU. When the bead capturing method was coupled with RT-PCR, the fluorescent signal remained detectable in virus spiked clinically relevant matrices, including throat swab samples, sputum samples, and serum samples [34]. Wang et al. performed an in vitro selection specific for influenza virus H5N1. Purified hemagglutinin (HA) protein was used as target for the first four rounds, and then inactivated whole H5N1 viruses were used from round five to thirteen. The best candidate MRE displayed high affinity $\left(\mathrm{K}_{\mathrm{d}}=4.65 \mathrm{nM}\right)$ with only minimal cross binding activities on other avian 
influenza virus strains. A dot blot assay was developed with a LOD of 1.28 HAU, which was comparable to anti-H5 antibody. The dot blot assay also demonstrated the detection of the target virus in spiked chicken and duck swab samples [95]. Shiratori et al. chose recombinant influenza A HA protein as target for selection. After ten rounds of target selection, candidate sequences showed high binding affinities with reported $K_{d}$ values in the low nanomolar range. A sandwich enzyme linked aptamer assay (ELAA) was developed and showed similar binding responses on three strains of influenza A, H5N1, H1N1 and H3N2. However, the LOD was not determined [96].

A novel coronavirus caused a severe acute respiratory syndrome (SARS) outbreak in 2002 to 2003 [121]. Cho et al. identified ssDNA MREs specific for the SARS coronavirus nucleocapsid protein. After twelve rounds of positive selection, the best candidate MRE had a reported $\mathrm{K}_{\mathrm{d}}$ value of $4.93 \pm 0.3 \mathrm{nM}$. MRE modified Western blot showed a comparable detection level to nucleocapsid antibody based assay. However, the authors did not show cross binding reactivity of the selected MREs toward other viral proteins [10].

GO-SELEX was utilized to identify ssDNA MREs specific for bovine viral diarrhea virus. After five rounds of positive and negative selections, three best candidate MREs had reported $\mathrm{K}_{\mathrm{d}}$ values of $4.08 \times 10^{4}, 4.22 \times 10^{4}$ and $5.2 \times 10^{4} \mathrm{TCID}_{50} / \mathrm{mL}$ respectively by SPR kinetics analysis. All candidate MREs showed very high specificity toward the target. A sandwich SPR detection assay was developed wherein a biotinylated MRE was immobilized on streptavidin coated gold chip as the capturing MRE, and a second different MRE with thiol modification was conjugated to gold nanoparticle as the reporting MRE. A LOD of 800 copies of virus/mL was reported with this assay [24]. 
Hepatitis C virus (HCV) envelope surface glycoprotein E2 was chosen as target for selection by Chen et al. E2 protein was expressed on a murine colon carcinoma cell line, CT26 cells, and used as target for positive selection. The native CT26 cells were used as counter target. After thirteen rounds of selection, the best candidate MRE showed high affinity and specificity toward E2-positive cells. An ELISA virus capture assay was developed by using biotinylated MRE as reporter and demonstrated the detection of HCV in clinical human serum samples. In addition, the MRE, termed ZE2 also displayed therapeutic effect by inhibiting E2 protein binding to CD81 and blocking HCV infection of human hepatocytes in vitro [97].

Dengue virus is a member of family Flaviviridae, genus flavivirus. It is a mosquito-borne RNA virus that can cause gangue fever, dengue hemorrhagic fever, and dengue shock syndrome [122]. Gandham et al. used recombinant dengue virus type-2 envelope protein domain III as target of interest to perform an in vitro selection of thiophosphate ester modified ssDNA MREs. After five rounds of target selection, the best MRE had a reported $K_{d}$ value of $154 \pm 40 \mathrm{nM}$, but no cross binding experiments were performed [98].

CE-SELEX was performed by Mosing et al. to identify ssDNA MREs specific for HIV reverse transcriptase. After only four rounds of selection, the best candidate MRE had an ultrahigh affinity with a reported $\mathrm{K}_{\mathrm{d}}$ value in the picomolar range. Interestingly, there were no identifiable consensus sequence families in the round four ssDNA library. The authors claimed that the selected MRE had the highest affinity for the target of interest when compared to MREs selected by other methods, and suggested multiple ultra-high affinity MREs might exist in the enriched library [99]. 


\subsubsection{Single-stranded DNA MREs Targeting Toxins}

\subsubsection{Biological Toxins/Virulence Factors}

Secretory proteins, virulent factors, exotoxins, or small molecule toxins from bacteria, fungus and other organisms are important biomarkers in medical diagnosis, environmental monitoring and as well as in food safety surveillance. The following section discusses recent studies in the identification and biosening application of ssDNA MREs specific for biological toxins (Table 1.4).

Table 1.4: Summary table of ssDNA MRE targeting biological toxins and virulence factors.

\begin{tabular}{|c|c|c|c|c|c|}
\hline Target & $\begin{array}{l}\text { SELEX } \\
\text { Method }\end{array}$ & $\overline{\mathbf{K}_{\mathbf{d}}}$ & Detection Method & LOD & $\begin{array}{l}\text { Referenc } \\
\text { e }\end{array}$ \\
\hline Enterotoxin B & $\begin{array}{l}\text { Magnetic } \\
\text { Beads }\end{array}$ & - & $\begin{array}{l}\text { Electrochemiluminescenc } \\
\mathrm{e}\end{array}$ & $10 \mathrm{pg}$ & [123] \\
\hline Enterotoxin B & $\begin{array}{l}\text { Magnetic } \\
\text { Beads }\end{array}$ & - & - & - & {$[11]$} \\
\hline Enterotoxin C1 & $\begin{array}{l}\text { Magnetic } \\
\text { Beads }\end{array}$ & $\begin{array}{l}65.14 \pm \\
11.64 \mathrm{nM}\end{array}$ & Fluorescence & $6 \mathrm{ng} / \mathrm{mL}$ & [124] \\
\hline Cholera toxin & $\begin{array}{l}\text { Magnetic } \\
\text { Beads }\end{array}$ & - & $\begin{array}{l}\text { ELAA/ } \\
\text { Electrochemiluminescenc } \\
\text { e }\end{array}$ & $\begin{array}{l}10 \mathrm{ng} \\
40 \mathrm{ng}\end{array}$ & {$[123]$} \\
\hline $\begin{array}{l}\text { C. } \operatorname{diff} \text { Toxin A/ } \\
\text { Toxin B/ Binary } \\
\text { Toxin }\end{array}$ & $\begin{array}{l}\text { Magnetic } \\
\text { Beads/ } \\
\text { SOMAmer }^{\mathrm{TM}}\end{array}$ & $\begin{array}{l}\text { Sub to low } \\
\text { nanomolar } \\
\text { range }\end{array}$ & Various & $1 \mathrm{pmol} / \mathrm{L}$ & [125] \\
\hline $\begin{array}{l}\text { C. diff Binary } \\
\text { Toxin }\end{array}$ & $\begin{array}{l}\text { Sandwich } \\
\text { SELEX/ } \\
\text { SOMAmer }^{\mathrm{TM}}\end{array}$ & $\begin{array}{l}0.02-2.7 \\
\mathrm{nM}\end{array}$ & Sandwich assays & $\begin{array}{l}\text { Low } \\
\text { picomolar }\end{array}$ & {$[126]$} \\
\hline C. diff Toxin B & $\begin{array}{l}\text { Magnetic } \\
\text { Beads }\end{array}$ & $\begin{array}{l}47.3 \pm 13.7 \\
\mathrm{nM}\end{array}$ & Modified ELISA & $50 \mathrm{nM}$ & [127] \\
\hline $\begin{array}{l}\text { CFP-10.ESAT-6 } \\
\text { heterodimer }\end{array}$ & $\begin{array}{l}\text { Nitrocellulos } \\
\text { e }\end{array}$ & $\begin{array}{l}\text { Low } \\
\text { nanomolar } \\
\text { range }\end{array}$ & Colorimetric (ELONA) & $\begin{array}{l}100 \% \\
\text { sensitivity } \\
, 68.75 \% \\
\text { specificity }\end{array}$ & [9] \\
\hline $\begin{array}{l}\text { CFP-10.ESAT-6 } \\
\text { heterodimer }\end{array}$ & Microwell & $\begin{array}{l}375 \mathrm{nM} / \\
160 \mathrm{nM}\end{array}$ & Colorimetric (ELONA) & $\begin{array}{l}89.6- \\
100 \% \\
\text { sensitivity } \\
\end{array}$ & [128] \\
\hline
\end{tabular}




\begin{tabular}{|c|c|c|c|c|c|}
\hline & Plate & & & $\begin{array}{l}\text {, 94.1\% } \\
\text { specificity }\end{array}$ & \\
\hline $\begin{array}{l}\text { MPT64 } \\
\text { TB protein }\end{array}$ & $\begin{array}{l}\text { Microwell } \\
\text { Plate }\end{array}$ & - & Sandwich assays & - & [129] \\
\hline Protective Antigen & CE-SELEX & $112 \mathrm{nM}$ & Electrochemical (SWNT) & $1 \mathrm{nM}$ & [130] \\
\hline Protective antigen & $\begin{array}{l}\text { Membrane } \\
\text { filtration }\end{array}$ & $\begin{array}{l}\text { nanomolar } \\
\text { range }\end{array}$ & ELISA & - & [131] \\
\hline $\begin{array}{l}\text { Botulinum } \\
\text { neurotoxin type A } \\
\text { heavy chain } \\
\text { peptide/ toxoid }\end{array}$ & $\begin{array}{l}\text { Single } \\
\text { micobead }\end{array}$ & $\begin{array}{l}\text { Nano to } \\
\text { micromola } \\
\text { r range }\end{array}$ & - & - & [30] \\
\hline $\begin{array}{l}\text { Botulinum } \\
\text { neurotoxin type A } \\
\text { light chain }\end{array}$ & $\begin{array}{l}\text { Microfluidic- } \\
\text { SELEX }\end{array}$ & $\begin{array}{l}\text { Low } \\
\text { nanomolar } \\
\text { range }\end{array}$ & - & - & {$[32]$} \\
\hline $\begin{array}{l}\text { Botulinum } \\
\text { neurotoxin type A } \\
\text { light chain }\end{array}$ & $\begin{array}{l}\text { Magnetic } \\
\text { Beads }\end{array}$ & - & Fluorescence & $1 \mathrm{ng} / \mathrm{mL}$ & [132] \\
\hline Microcystin & Sepharose gel & Ka: $10^{3} \mathrm{M}^{-1}$ & SPR & - & [133] \\
\hline $\begin{array}{l}\text { Cylinrospermospi } \\
\text { n }\end{array}$ & $\begin{array}{l}\text { Sepharose } \\
\text { Beads }\end{array}$ & $88.78 \mathrm{nM}$ & Electrochemical & 100 pM & [134] \\
\hline Saxitoxin & $\begin{array}{l}\text { Magnetic } \\
\text { Beads }\end{array}$ & - & - & - & [135] \\
\hline Okadaic acid & $\begin{array}{l}\text { Magnetic } \\
\text { Beads }\end{array}$ & $77 \mathrm{nM}$ & Electrochemical & $70 \mathrm{pg} / \mathrm{mL}$ & [12] \\
\hline Ochratoxin A & Agarose resin & $200 \mathrm{nM}$ & Fluorescence Polarization & $5 \mathrm{nM}$ & {$[136,137]$} \\
\hline Ochratoxin A & $\begin{array}{l}\text { Magnetic } \\
\text { Beads }\end{array}$ & $96-293 \mathrm{nM}$ & ELAA & $1 \mathrm{ng} / \mathrm{mL}$ & [138] \\
\hline Ochratoxin A & $\begin{array}{l}\text { Sepharose } \\
\text { Beads }\end{array}$ & $\begin{array}{l}\text { High } \\
\text { nanomolar } \\
\text { range }\end{array}$ & Fluorescence & $9 \mathrm{nM}$ & [139] \\
\hline Fumonisin $\mathbf{B}_{1}$ & $\begin{array}{l}\text { Magnetic } \\
\text { beads }\end{array}$ & $100 \mathrm{nM}$ & - & - & [13] \\
\hline Zearalenone & $\begin{array}{l}\text { Magnetic } \\
\text { Beads }\end{array}$ & $41 \pm 5 \mathrm{nM}$ & Fluorescence & $0.785 \mathrm{nM}$ & {$[140]$} \\
\hline T-2 toxin & GO-SELEX & $\begin{array}{l}20.8 \pm 3.1 \\
\mathrm{nM}\end{array}$ & Fluorescence & $0.4 \mu \mathrm{M}$ & [141] \\
\hline Aflatoxin B1 & $\begin{array}{l}\text { Magnetic } \\
\text { Beads }\end{array}$ & $\begin{array}{l}11.39 \pm \\
1.27 \mathrm{nM}\end{array}$ & Fluorescence & 35 ng/L & [142] \\
\hline Aflatoxin B1/ M1 & $\begin{array}{l}\text { Magnetic } \\
\text { Beads }\end{array}$ & $\begin{array}{l}96-221 \mathrm{nM} \\
35-1515 \\
\mathrm{nM}\end{array}$ & Colorimetric/ AuNPs & $\begin{array}{l}250-500 \\
\text { nM } \\
\text { (Aflatoxin } \\
\text { M1) }\end{array}$ & [143] \\
\hline $\begin{array}{l}\text { Alpha } \\
\text { Bungarotoxin }\end{array}$ & $\begin{array}{l}1 \text { step } \\
\text { SELEX }\end{array}$ & $7.58 \mu \mathrm{M}$ & - & - & [31] \\
\hline Alpha Toxin & $\begin{array}{l}\text { Magnetic } \\
\text { Beads }\end{array}$ & $\begin{array}{l}93.7 \pm 7 \\
\mathrm{nM}\end{array}$ & Modified ELISA & $200 \mathrm{nM}$ & [144] \\
\hline Alpha Toxin & Filter & - & - & - & [145] \\
\hline
\end{tabular}


Staphylococcus aureus can secrete a group of thermostable enterotoxins that have been shown to contaminate food. Reports suggest that these toxins are a common cause of foodborne illnesses [146]. There are many types and subtypes of staphylococcus enterotoxins. Bruno et al. first selected ssDNA MREs that bind to enterotoxin B by using magnetic bead immobilized target. An electrochemiluminescence assay was developed to demonstrate a detection limit of less than $10 \mathrm{pg}$ of enterotoxin B. However, no kinetic data or crossing-binding profiles were presented in the study [123]. DeGrasse identified a ssDNA MRE specific for enterotoxin B after fourteen rounds of mixed target and negative targets selection. A MRE based precipitation assay was used to analyze the selectivity of candidate MREs in cell-free culture supernatant from multiple strains of S. aureus. The high selectivity of candidate MREs was confirmed by capturing only the target toxin in the precipitation assay. However, no quantitative binding data was presented in the study [11]. Enterotoxin subtype C1 was chosen as target for selection by Huang et al. After twelve rounds of selection, the best candidate MRE demonstrated high affinity for enterotoxin $\mathrm{C} 1\left(\mathrm{~K}_{\mathrm{d}}=65.14 \pm 11.64 \mathrm{nM}\right)$. Cross binding experiments showed the selected MRE had high specificity and low cross binding activities on staphylococcus enterotoxin A, enterotoxin B and other protein molecules. A graphene oxide based fluorescence detection assay was developed and achieved a reported LOD of $6 \mathrm{ng} / \mathrm{mL}$ in artificially contaminated bufferdiluted milk samples [124].

Bruno et al. 2002 selected a ssDNA MRE against cholera toxin. An enzyme linked colorimetric assay showed a detection limit of less than $10 \mathrm{ng}$ of cholera toxin, and a electrochemiluminescent assay show a detection limit of less than $40 \mathrm{ng}$. However, affinity, crossing binding data, and MRE sequences were not presented in the study [123]. 
Toxigenic strains of Clostridium difficile can produce toxin A and toxin B, which are the contributing factor of $C$. difficile induced diarrhea. Rapid diagnosis of the condition is crucial in facilitating patient recovery and disease control [147]. Some strains of $C$. difficile also secret a binary toxin that can inhibit actin polymerization [148]. Ochsner et al. selected several slow offrate modified ssDNA MREs (SOMAmerTM) specific for toxins A, B and binary toxin. Several DNA libraries with modifications, such as 5-benzylaminocarbonyl-dU (BndU), 5naphthylmethylaminocarbonyl-dU (NapdU), 5-tryptaminocarbonyldU (TrpdU), 5-phenylethyl-1aminocarbonyl (PEdU), 5-tyrosylaminocarbonyl-dU (TyrdU), or 5-(2-naphthylmethyl) aminocarbonyl (2NapdU) were used in selections. Truncated recombinant toxins were used as targets. Equilibrium dissociation constants of selected SOMAmers ${ }^{\mathrm{TM}}$ were in pico to nanomolar range. The affinities for native toxins were slightly lower, but were remain in the low nanomolar range for majority of the candidate sequences. Pull-down capture, dot blots and antibody sandwich assays were developed with a reported LOD of $300 \mathrm{pg} / \mathrm{mL}$. Selected SOMAmers ${ }^{\mathrm{TM}}$ were able to detect all three toxins in cell-free culture supernatants of toxigenic C. difficile [125]. Ochsner et al. performed another in vitro selection on $C$. difficile binary toxin with sandwich SELEX. The advantage of sandwich SELEX is to select SOMAmer ${ }^{\mathrm{TM}}$ pairs that target different epitopes of the target protein. The reported $K_{d}$ values of selected SOMAmers ranged from 0.02 to $2.8 \mathrm{nM}$. A SOMAmer sandwich assay was developed with a reported LOD in the low picomolar range. The authors claimed that these studies showed the high potential for the development of sensitive and specific diagnostic kits [126].

Hong et al. performed a selection on C. diff toxin B and developed a proof-of-concept ssDNA MRE modified ELISA for sensitive target detection in human fecal matter. This work will be discussed in detail in Chapter 3 [127]. 
Tuberculosis (TB) remains to be a challenging disease in developing countries. Recent discovery of multi-drug resistant strains of Mycobacterium tuberculosis has further increased public concerns, however, current diagnostic techniques for TB are either time consuming or insensitive [149-151]. Rotherham et al. performed a selection on CFP-10.ESAT6 heterodimer, a specific biomarker for TB infections. After six rounds of selection, SPR binding studies showed candidate ssDNA MREs had affinities in the nanomolar range. One of the candidate MRE was tested in an enzyme linked oligonucleotide assay (ELONA). The authors reported the assay had $100 \%$ sensitivity and $68.75 \%$ specificity in clinical sputum samples using Youden’s index. However, the time needed for assay completion and crossing binding activities to other antigens were major limitations of the assay [9]. Tang et al. performed a selection on the same CFP10.ESAT6 heterodimer. After seventeen rounds of selection, $K_{d}$ values of candidate MREs were in the low nanomolar range. Two ssDNA MREs (CE24, CE 15) were used in an ELONA assay. The reported sensitivity and specificity of CE24 MRE based ELONA were 100\% and 94.1\% respectively. CE15 MRE based ELONA had a lower sensitivity of 89.6\%, but the specificity was the same. Assays were tested with both pulmonary and extrapulmonary serum samples from TB patients [128].

MPT64 is a secreted protein of M. tuberculosis and can be used as biomarker for active TB infections [152]. Qin et al. performed twelve rounds of selection on MPT64. Affinities of truncated candidate ssDNA MREs, containing only a 35-base central random region, were qualitatively observed using streptavidin-horse radish peroxidase (HRP) binding to proteinbound biotin-tagged MREs. A colorimetric sandwich assay using two different MREs was developed to detect the presence of MPT64 in culture filtrates. The sandwich assay achieved sensitivity and specificity of $86.3 \%$ and $88.5 \%$ respectively [129]. 
Protective antigen (PA) is a secreted virulence factor of Bacillus anthracis that binds to anthrax toxin receptors on mammalian cells and subsequently causes cell dysfunction and death [153]. Cella et al. utilized CE-SELEX to identify a ssDNA MRE targeting PA with high affinity and specificity. After six rounds of CE-SELEX, the best candidate had a reported $\mathrm{K}_{\mathrm{d}}$ value of $112 \mathrm{nM}$. An electrochemical biosensor was developed by immobilizing 5' amino modified MRE on 1-pyrenebutanoic acid succinimidyl ester (PASE) modified single wall carbon nanotubes (SWNT). The sensor showed low cross binding activity toward human and bovine serum albumin at $100 \mathrm{nM}$ concentration. The sensor surface could be regenerated using $1 \mu \mathrm{L}$ of $6 \mathrm{M}$ guanidium hydrochloride for 15 minutes followed by a wash with $10 \mathrm{mM}$ phosphate buffer. A reported LOD of $1 \mathrm{nM}$ was achieved [130]. Choi et al. performed an in vitro selection on PA. After eight rounds of selection, four candidate sequences had high affinities for PA ( $K_{d}$ in low nanomolar range), and two of the four candidates had low cross binding activities toward bovine serum albumin and bovine serum [131].

Botulinum neurotoxins (BoNT) are produced by Clostridium botulinum. In additional to its medical uses, it can also cause serious foodborne illnesses and may potentially be used as a biological weapon [154]. Tok et al. used a novel single microbead SELEX to perform selection of ssDNA MREs specific to aldehyde-inactivated BoNT type A toxin (BoNT/A-toxoid) and BoNT type A heavy chain peptide (BoNT/A Hc-peptiod). Targets were immobilized onto NiNTA agarose or amine-functionalized polystyrene TentaGel beads. A single target-immobilized microbead was incubated with the ssDNA library and retrieved for PCR amplification of bound ssDNA molecules. After only two rounds of selection, five candidate sequences specific for BoNT/A Hc-peptiod had $\mathrm{K}_{\mathrm{d}}$ values ranging from $1.09 \mu \mathrm{M}$ to $4.20 \mu \mathrm{M}$. Three candidate sequences specific for BoNT/A-toxoid had $\mathrm{K}_{\mathrm{d}}$ values ranging from $3 \mathrm{nM}$ to $51 \mathrm{nM}$. The authors 
reported that all MREs specific to BoNT/A Hc-peptiod were able to competitively inhibit the binding between the toxin peptide and anti-BoNT antibody, and potentially be used as a therapeutic agent [30].

Lou et al. utilized a novel microfluidic device to facilitate the partitioning of a small volume of target coated magnetic beads (M-SELEX). The library achieved a very high overall affinity $\left(\mathrm{K}_{\mathrm{d}}=33 \pm 8 \mathrm{nM}\right)$ against BoNT/A light chain after only one round of selection. Four candidate sequences had a range of $K_{d}$ values between 34 to $86 \mathrm{nM}$. The authors claimed that their M-SELEX could be readily adapted to any bead immobilized targets or whole cell target [33]. Bruno et al. immobilized BoNT/A light chain on magnetic beads and performed ten rounds of selection. The best candidate MRE was fluorescently tagged and used as a reporter for target detection. The reported LOD of $1 \mathrm{ng} / \mathrm{mL}$ was achieved in buffer. However, the MRE reporter also bound to structurally similar targets, BoNT type B, type E holotoxins and heavy or light chain components, in a soil dilution. The author compared their MRE sequence to previous ssDNA MRE specific for BoNT and found consensus short sequence segments. This suggested that the binding between BoNTs and MREs may be conserved within these consensus segments [132].

Microcystin is a hepatotoxin produced by cyanobacteria. Three different analogs of microcystin were used in the study performed by Nakamura et al. Microrocystin LR, containing a leucine substituent was immobilized and used for twelve rounds of target selection. However, surface plasmon resonance binding data indicated a higher binding level between the selected MRE and microcystin YR, an analog containing a tyrosine substituent. There was also significant binding to microcystin RR, an analog containing an arginine substituent. The reported binding affinity $\left(\mathrm{K}_{\mathrm{a}}\right)$ was low, at approximately $10^{3} \mathrm{M}^{-1}$. This early work did not demonstrate the 
high affinity and specificity properties of MREs, however, it did show the possibility of using MREs as a binding molecule in a label-free detection system [133].

Cylindrospermopsin (CYN) is another water soluble and heat stable alkaloid secreted by a large group of fresh water cyanobacteria. It has a variety of toxic effects in human bodies ipon exposure to cylindrospermopsin usually through drinking water or food [155]. Elshafey et al. recently selected a ssDNA MRE with high affinity and specificity toward CYN, with a reported $\mathrm{K}_{\mathrm{d}}$ value of $88.78 \mathrm{nM}$. Circular dichroism measurements showed the MRE had a conformational change upon binding to CYN. This property was exploited in a label-free impedimetirc biosensor. The reported LOD of the sensor was $100 \mathrm{pM}$ with a linear range of $80 \mathrm{nM}$. It also showed negligible responses toward coexistent cyanobacterial toxins of microcystin-LR and Anatoxin-a. CYN was recoverable in a spike test with tap water [134].

Saxitoxin is a small neurotoxin produced by few dinoflagellates and certain cyanobacteria that affect marine organisms [156]. Handy et al. were the first to select a ssDNA MRE against target saxitoxin. In their study, saxitoxin was conjugated to keyhole limpet hemocyanin (KLH) via a spacer compound, 2,2'-(ethylenedioxy)bis(ethylamine), or Jeffamine, then the protein-toxin conjugate immobilized on magnetic beads. Ten rounds of selection were performed, and negative selection against KLH-bead was carried out from round four to the round ten, in order to decrease non-specific binding to KLH and beads. One candidate sequence was analyzed by SPR and demonstrated a concentration-dependent and selective binding to saxitoxins. However, the $K_{d}$ value of the selected MRE was not presented in the study [135].

Okadaic acid (OA) is a phycotoxin produced by Dinophysis and Prorocentrum algae. It can accumulate in shellfish due to its lipophlic and heat-stable nature. Human consumption of OA can lead to a variety of gastrointestinal symptoms [157]. Eissa et al. identified a ssDNA 
MRE with high affinity and specificity toward OA after eighteen rounds of mixed target and negative target selection. The candidate MRE with the highest affinity $\left(\mathrm{K}_{\mathrm{d}}=77 \mathrm{nM}\right)$ was chosen for circular dichoism analysis. A conformational change in the MRE was observed upon binding of OA. A label-free electrochemical impedimetric biosensor was developed with this MRE and achieved a LOD of $70 \mathrm{pg} / \mathrm{mL}$. It demonstrated no cross binding activities toward structurally similar toxins, including dinophysis toxins-1 and 2 and microcystin-LR [12].

Ochratoxin A (OTA) is a mycotoxin produced by members of the Aspergillus and Penicillium genera. It is a nephrotoxin and has potential carcinogenic effects in humans. It has been shown as a contaminant in many food products, such as grains and wine [158]. However, the current detection method for OTA is both expensive and time consuming [159]. CruzAguado et al. identified a ssDNA MRE specific for OTA after thirteen rounds of selection. The best candidate MRE reported had a $K_{d}$ value of $200 \mathrm{nM}$. It did not bind non-specifically to warfarin, N-acetyl-L-phenylalanine, or ochratoxin B in a fluorescent based cross-binding assay [136]. Subsequently, the authors developed a detection system based on a fluorescence polarization displacement assay. The author reported the assay was sensitive to OTA, but not to warfarin and N-acetyl-L-phenylalanine, with a LOD of $5 \mathrm{nM}$. However, the detection assay did not test ocharatoxin B (OTB) binding activity or sensitivity in food sample [137]. Barthelmebs et al. also selected ssDNA MRE specific for OTA. Several candidate MREs were identified after fourteen rounds of selection. After binding and cross binding analysis, the best candidate had a $\mathrm{K}_{\mathrm{d}}$ value of $96 \mathrm{nM}$ with minimal binding to OTB and phenylalanine. It was incorporated into an ELISA and ELAA assays for the detection of OTA spiked in pretreated wine samples. Different ELAA and ELISA assays were compared, and a direct competitive ELAA had the lowest detection limit of $1 \mathrm{ng} / \mathrm{mL}$ with the shortest analysis time of 125 minutes [138]. McKeague et al. 
performed fifteen rounds of in vitro selection to identify ssDNA MREs specific for OTA. Two candidate MREs had reported $K_{d}$ values of $110 \pm 50 \mathrm{nM}$ (designated B08) and $290 \pm 150 \mathrm{nM}$ (designated A08). A08 ssDNA MRE was utilized in a label-free fluorescence detection assay, and achieved a LOD of $9 \mathrm{nM}$. It also had low cross binding activity on OTB and warfarin. The authors reported a truncated version of A09 also had similar specificity and binding affinity profiles [139].

Fumonisins are heat-stable mycotoxins present in most corn and are produced by fungi, Fusarium verticillioides and Fusarium proliferatum. Fumonisin $\mathrm{B}_{1}\left(\mathrm{FB}_{1}\right)$ is a nephrotoxin and potential carcinogen in humans. As the toxin cannot be inactivated by cooking in high temperature, it is crucial to monitor its level during food production [160]. McKeague et al. performed eight rounds of selection to identify a ssDNA MRE with high binding affinity toward $\mathrm{FB}_{1}$. Unmodified magnetic beads (immobilization substrate), L-homocysteine, L-cysteine, and L-methionineL-glutamic acid were used as negative targets in the selection. Six candidate MREs were identified, and the best candidate MRE had a reported $\mathrm{K}_{\mathrm{d}}$ of $100 \mathrm{nM}$. However, the authors did not test the specificity of the selected MRE on other mycotoxins [13].

Zearalenone (ZEN; F-2 toxin) is a nonsteroidal estogenic mycotoxin produced by many fungus species in the Fusarium genus. It has been shown to be present in many grains worldwide, such as oats, wheat, rice and their derived food products [161]. Chen et al. performed fourteen rounds of selection, the best candidate MRE had a reported $\mathrm{K}_{\mathrm{d}}$ of $41 \pm 5 \mathrm{nM}$ and high specificity. Crossing binding assays showed insignificant binding to other mycotoxins, $\beta$-zearalenol, aflatoxin B1, aflatoxin $\mathrm{B} 2$, fumonisin $\mathrm{B}_{1}$ and fumonisin $\mathrm{B}_{2}$. Circular dichroism measurement showed a conformational change of the MRE after binding of zearalenone. A detection assay 
using MRE immobilized magnetic beads and the blue-green florescence property of zearalenone was developed. A LOD of $0.785 \mathrm{nM}$ was achieved in pretreated beer samples [140].

$\mathrm{T}-2$ toxin (T-2) is a trichothecene mycotoxins produced by many species in the Fusarium genus and is harmful to humans. It is a very stable small molecule biological toxin that is resistant to high temperature and is present in variety of grains, such as oats, barley, wheat and more. Currently, it can only be detected by labor intensive and costly instruments, and is thus difficult to monitor its level in food [162] . Chen et al. recently utilized ten rounds of GOSELEX to identify a ssDNA MRE specific for T-2 with high affinity and specificity. Fluorescent binding and cross-binding assay showed that the $\mathrm{K}_{\mathrm{d}}$ value of the best candidate MRE was in the nanomolar range, with insignificant cross binding activities on $\mathrm{FB}_{1}$, ZEN, OTA and aflatoxin B1. There was a conformational change upon MRE-T-2 binding. The authors also developed a fluorescent assay to detect spiked T-2 level in beer. A LOD of $0.4 \mu \mathrm{M}$ was achieved [141].

Aflatoxins are highly toxic natural compounds produced by many species of filamentous fungi and can contaminate agricultural products. The $\mathrm{LD}_{50}$ can be as low as $0.5 \mathrm{mg} / \mathrm{kg}$, and acute toxicity is even higher than many chemical toxins, such as cyanide or arsenic [163, 164]. Ma et al. performed an in vitro selection on a subtype of aflatoxins, aflatoxins B1 (AFB1). After ten rounds of target and negative target selection, the best candidate MRE had a reported $K_{d}$ value of $11.39 \pm 1.27 \mathrm{nM}$ and with minimal cross binding activities on aflatoxins B2, G1, G2, OTA and $\mathrm{FB}_{1}$. A fluorescent assay similar to the authors' previous study on ZEN and T-2 specific MRE was developed to detect spiked levels of AFB1 in methanol-extracted peanut oil. The assay achieved a LOD of $35 \mathrm{ng} / \mathrm{L}$ [142]. Malhotra et al. perform two selections (SELEX1 and SELEX2) using slightly different methodologies to identify ssDNA MREs specific for both AFB1 and aflatoxins M1 (AFM1). In SELEX1, lambda exonuclease was used to generate ssDNA from 
amplified dsDNA. AFM1 coated magnetic beads were used as a positive target from round 1 to round 10, and AFB1 coated magnetic beads were used as positive target at round 11 (last round) only. Free targets were used to competitively elute ssDNA that bound to toxin coated beads in round 10 and round 11. In SELEX2, each round started from pre-incubation with counter targets (uncoated beads, AFB1 beads) followed by incubation with AFM1 beads. Snap cooling was used to obtain ssDNA from dsDNA. In SELEX2, only eight rounds were carried out. Multiple candidate MREs were analyzed and their $\mathrm{K}_{\mathrm{d}}$ values were in the nano to low microloar range. One MRE with the best affinity $\left(\mathrm{K}_{\mathrm{d}}=35.6 \pm 2.9 \mathrm{nM}\right)$, designated AFAS3, was used in developing a colorimetric assay based on MRE immobilized gold nanoparticles. This assay had a detection range of 250 to $500 \mathrm{nM}$ of AFM1, and only minor interaction with AFB1. However, there were no reported cross binding data on other mycotoxins [143].

Two studies identified ssDNA MREs specific for biological toxins with therapeutic intentions. Alpha-Bungarotoxin is a toxic substance in krait snake venom and can bind irreversibly to acetylcholine receptors and eventually lead to death in victims $[165,166]$. Lauridsen et al. performed a rapid one-step SELEX and identified a ssDNA MRE with relatively high binding affinity toward Alpha-Bungarotoxin $\left(\mathrm{K}_{\mathrm{d}}=7.58 \mu \mathrm{M}\right)$. The authors claimed that rapid selection technique could potentially be used with a chemically modified nucleic acid library, and generate MREs suitable for diagnostic and therapeutic purposes [31].

Vivekananda et al. selected a ssDNA MRE specific for alpha toxin of Staphylococcus aureus. Several candidate sequences showed cell rescuing effects when co-administrated with alpha toxin in multiple in vitro neutralization assays. The authors claimed that it was possible to generate MREs against alpha toxin for the treatment of S. aureus infections [145]. 
Hong et al. also performed an in vitro selection on S. aureus alpha toxin and developed a proof-of-principle modified ELISA using ssDNA MRE for sensitive target detection in human serum. This work will be described in detail in Chapter 4 [144].

\subsubsection{Chemical Toxins}

The detection of chemical toxins is important in both food safety and environmental monitoring. Environmental and food contamination by various kinds of chemical toxins have been reported, and even at low concentrations can still be detrimental to human health. Currently, the majority of small chemical toxins can only be detected by labor intensive and costly laboratory equipments such as, liquid and/or gas chromatography coupled with mass spectrometry. In order to address these current limitations, there has been an increase in the identification and biosensing applications of MREs with high affinity and specificity to capture and detect chemical toxins. However, the in vitro selection of ssDNA MREs targeting small molecule chemical toxins has several inherent challenges, such as difficulties in efficient separation between bound and unbound DNA molecules, limited chemical motifs on target surfaces for sufficient binding, lack of chemical functional groups for target immobilization, and candidate MREs that may not have sufficient specificities to distinguish molecules with very similar chemical structures if selection schemes are not carefully designed. For these reasons, there are a limited number of ssDNA MREs specific for chemical toxins currently in the literature (Table 1.5).

Table 1.5: Summary table of ssDNA MREs targeting chemical toxins.

\begin{tabular}{|c|c|c|c|c|}
\hline Target & SELEX Method $\mathbf{K}_{d}$ & Detection & LOD & Reference \\
\hline
\end{tabular}




\begin{tabular}{|c|c|c|c|c|c|}
\hline & & & Method & & \\
\hline 17ß-estradiol (E2) & $\begin{array}{l}\text { Sepharose } \\
\text { column }\end{array}$ & $0.13 \mu \mathrm{M}$ & Electrochemical & $0.1 \mathrm{nM}$ & [167] \\
\hline 17ß-estradiol (E2) & $\begin{array}{l}\text { Sepharose } \\
\text { column }\end{array}$ & $50 \mathrm{nM}$ & $\begin{array}{l}\text { Dynamic light } \\
\text { scattering, } \\
\text { resistive pulse } \\
\text { sensing }\end{array}$ & $\begin{array}{l}5 \mathrm{nM}-100 \\
\mathrm{nM}\end{array}$ & [168] \\
\hline Bisphenol A & $\begin{array}{l}\text { Epoxy-activated } \\
\text { resin }\end{array}$ & $8.3 \mathrm{nM}$ & Fluorescence & $\begin{array}{l}\text { Nanomolar } \\
\text { range }\end{array}$ & [169] \\
\hline $\begin{array}{l}\text { Polychlorinated } \\
\text { biphenyls }\end{array}$ & FluMag-SELEX & $\begin{array}{l}\text { Low } \\
\text { micromolar } \\
\text { range }\end{array}$ & Fluorescence & $\begin{array}{l}0.1 \text { to } 100 \\
\mathrm{ng} / \mathrm{mL}\end{array}$ & [170] \\
\hline $\begin{array}{l}\text { Polychlorinated } \\
\text { biphenyls }\end{array}$ & Magnetic Beads & $\begin{array}{l}\text { nanomolar } \\
\text { range }\end{array}$ & - & - & [171] \\
\hline Atrazine & CE-SELEX & $890 \mathrm{nM}$ & $\begin{array}{l}\text { Fluorescence } \\
\text { Polarization }\end{array}$ & - & [172] \\
\hline Atrazine & Magnetic Beads & $\begin{array}{l}0.62 \pm 0.21 \\
\mathrm{nM}\end{array}$ & $\begin{array}{l}\text { Magnetic beads } \\
\text { capturing coupled } \\
\text { with CE }\end{array}$ & $\begin{array}{l}\text { Nanomolar } \\
\text { range }\end{array}$ & [14] \\
\hline Malathion & Magnetic Beads & $\begin{array}{l}1.14 \pm 0.7 \\
\mathrm{nM}\end{array}$ & - & - & {$[15]$} \\
\hline Bromacil & Magnetic Beads & $\begin{array}{l}9.6 \pm 7.8 \\
\mathrm{nM}\end{array}$ & - & - & {$[16]$} \\
\hline $\begin{array}{l}\text { Tebuconazole } \\
\text { Mefenacet } \\
\text { Inabenfide }\end{array}$ & GO-SELEX & $10-100 \mathrm{nM}$ & Colorimetric & $\begin{array}{l}100-400 \\
\mathrm{nM}\end{array}$ & {$[25]$} \\
\hline $\begin{array}{l}4 \text { organophosphorus } \\
\text { pesticides } \\
\text { phorate, profenofos, } \\
\text { isocarbophos, and } \\
\text { omethoate }\end{array}$ & $\begin{array}{l}\text { Filtration } \\
\text { column/ } \\
\text { Immobilization } \\
\text { free }\end{array}$ & $\begin{array}{l}\text { Low } \\
\text { micromolar } \\
\text { range }\end{array}$ & - & - & {$[28]$} \\
\hline Acetamiprid & $\begin{array}{l}\text { Immobilization } \\
\text { free }\end{array}$ & $4.98 \mu \mathrm{M}$ & - & - & {$[27]$} \\
\hline
\end{tabular}

Kim et al. identified a 76-mer ssDNA MRE specific for 17-beta-estradiol (E2) with a $\mathrm{K}_{\mathrm{d}}$ of $0.13 \mu \mathrm{M}$ after seven rounds of selection. Specificity of the selected MRE was shown by square wave voltametry (SWV) measurement, with only minimal binding to structurally similar 
organic chemicals 2-methoxynaphthalene and 1-aminoanthraquinone. The authors initiallyattempted SPR for the detection of E2. However, due to the small molecular weight of E2, there were no observable binding events by SPR. An electrochemical platform measured under SWV was eventually utilized to detect E2 with a LOD of $0.1 \mathrm{nM}$ in buffer solutions [167]. Alsager et al. selected a 75-mer ssDNA MRE specific for E2 with a $K_{d}$ of $50 \mathrm{nM}$ after eighteen rounds of selection. The 5' amino-modified MRE was covalently conjugated to carboxylated nanoparticles, and dynamic light scattering/ resistive pulse sensing was used to observe size contraction in particle size upon E2 binding. A detection range of $5 \mathrm{nM}$ to $100 \mathrm{nM}$ was achieved with this detection platform. Progesterone, testosterone, Bis (4 hydroxyphenyl) methane (BPF), and bisphenol-A (BPA) were also tested for the specificity of the selected MRE. The assay showed minimal binding to both BPA and BPF, however, the MRE was not able to distinguish the other two steroids [168].

Bisphenol A (BPA) is an estrogen mimicking chemical that has been classified as an endocrine-disrupting compound. It is used in the manufacture of polycarbonate plastic products, such as plastic bottles and containers. It has been shown to be released into food after heating, and can accumulate in human [173]. Jo et al. selected a ssDNA MRE specific for Bisophenol A with high affinity and specificity. The reported $\mathrm{K}_{\mathrm{d}}$ value was $8.3 \mathrm{nM}$ with only minimal binding to structurally related chemical molecules, including $6 \mathrm{~F}$ biophenol $\mathrm{A}$, bisphenol $\mathrm{B}$, and 4, 4'bisphenol. A cy-3 labeled MRE pair was immobilized on sol-gel biochip and a sandwich detection assay was developed with nanomolar range sensitivity. However, the authors acknowledged the assay system can only detect a limited range of BPA concentrations [169].

Polychlorinated biphenyls (PCB) are a group of chlorinated hydrocarbons that are used in varies of industrial settings. PCBs are highly toxic and are reported to be an environmental 
contaminant affecting water bodies and food sources [174]. Mehta et al. identified PCB binding ssDNA MREs with nanomolar range affinity. In their study, two PCB compounds with hydroxyl functional group were immobilized on magnetic beads, and used as target for selection. After nine rounds of selection, three candidate sequences were chosen for characterization. Two of the three candidate sequences (9.1 and 9.3) showed comparable binding affinities to both immobilized targets. In subsequent crossing binding analysis, candidate 9.1 showed broad substrate binding affinity to other PCB compounds, while candidate 9.2 showed a high specificity for the two PCBs with hydroxyl functional groups. The study did not test specificity on other hydrocarbons that are structurally similar to PCB [171]. Xu et al. immobilized a primary amine modified PCB compound (PCB77- $\mathrm{NH}_{2}$ ) on epoxy-activated Sepharose agarose as the target for in vitro selection. After eleven rounds of selection, four candidate sequences were characterized to have affinity in the low micromolar range. Cross binding assays showed only minimal binding toward other hydrocarbons and agarose substrate. A fluorescent based detection assay was developed using the fluorescence quenching property of gold nanoparticle. Upon binding to target, the fluorescent signal was released. A detection range of 0.1-100 ng/mL was achieved. This assay detected other PCB compounds with different sensitivities [170].

The current detection method for herbicides and pesticides environmental contaminants in the environment relies on using time consuming and labor intensive laboratory based equipments. MREs have been investigated as binding elements in rapid, field deployable detection systems. Atrazine is a widely used herbicide worldwide [175]. Sanchez utilized CESELEX to identify a ssDNA MRE specific for atrazine with a $\mathrm{K}_{\mathrm{d}}$ of $890 \mathrm{nM}$. However, the MRE did not show specificity in binding between atrazine and structurally closely related simazine at concentration below approximately $2 \mu \mathrm{M}$ in a fluorescence polarization detection assay [172]. 
Williams et al. also performed an in vitro selection of ssDNA MRE specific for atrazine. A derivative of atrazine, desethyl atrazine was first biotinylated, and then immobilized on streptavidin coated magnetic beads. The selection scheme was designed with increasing selection stringency, by incorporating negative selections on streptavidin magnetic beads, simazine, metabolites of atrazine and other commonly used pesticides. Competition selection was also performed to ensure the library bound only to free atrazine in solution, but not to desethyl atrazine. As a result, a ssDNA MRE with subnanamolar affinity and high specificity was identified after twelve rounds of selection. A magnetic bead based capture assay coupled with capillary electrophoresis was developed to detect atrazine in artificially contaminated river water samples. The assay was able to detect atrazine in the nanomolar range [14]. Similar in vitro selection methodology was also employed by Williams et al. to identify MREs specific for a commonly used organophosphate pesticide, malathion. In their second selection, the selected MRE had high nanomolar range affinity, and minimal binding to metabolites of malathion and other herbicides. However, the author noted the cross binding activity was high on bovine serum albumin possibility due to the large, globular characteristics of the protein [15]. William et al. subsequently performed another selection on an herbicide, bromacil. This study further validated the methodology the authors employed to identify MREs with high affinity and low cross binding activities on structurally similar compounds, and compounds that were likely to coexist in the environment. The authors noted that these properties were particularly important for incorporating ssDNA MREs as sensing elements in biosensors [16].

As noted above, not every chemical toxin can be readily immobilized for portioning during selection. In order to circumvent this limitation, Wang et al. utilized an immobilization free in vitro SELEX developed by Li and co-workers to select ssDNA MREs specific for four 
different organophosphorus pesticides, phorate, profenofos, isocarbophos and omethoate [26, 28]. After twelve rounds of selection, two candidate sequences reported $K_{d}$ values in the low micromolar range for all four targets. Cross binding assays showed good specificities for the selected two MREs, with only minimal observed binding to eight other different pesticides [28]. The same group of researchers later developed a fluorescence polarization assay using the selected MREs to detect phorate, profenofos, isocarbophos, and omethoate at a LOD of 19.2, 13.4, 17.2, and $23.4 \mathrm{nM}$, respectively [176].

He et al. employed immobilization-free SELEX to identify a ssDNA MRE specific for pesticide, acetamiprid. After eighteen rounds of selection, the best candidate MRE was reported to have a $\mathrm{K}_{\mathrm{d}}$ value of $4.96 \mu \mathrm{M}$. Specificity of the selected MRE was tested and cross-binding data showed no significant change in fluorescent signals in the presence of three other pesticides, imidacloprid, nitenpyram, and chlorpyrifos. The authors noted that the affinity of the selected MRE was lower than typical antibodies [27].

GO-SELEX was used to identify three ssDNA MREs specific to three different pesticides: tebuconazole, mefenacet and inabenfide [25]. The reported values of $K_{d}$ were in the range of 10 to $100 \mathrm{nM}$. High specificity of each identified MRE was also determined by isothermal titration calorimetric and gold nanoparticle colorimetric assays. A simple, rapid detection method using gold nanoparticles was developed with LOD ranges from 100 to $400 \mathrm{nM}$.

\subsection{General Classes of Detection Methods}

In recent years, a large number of researches have taken place in applying ssDNA MREs for the use in biosensors. Major detection methods can be categorized into three classes: 1) electrical/ electrochemical, 2) optical, and 3) mass sensitive. The following section highlights the basic principles of the general classes of detection methods that have been utilized widely in the 
development of ssDNA MRE based biosensors. Recent literatures describing the detection of pathogens, and toxins using ssDNA MREs biosensors are summarized in tables 1.6, 1.7, and 1.8.

Table 1.6: Summary table of ssDNA MRE based biosensors for the detection of pathogens.

\begin{tabular}{|c|c|c|c|c|c|}
\hline Target & $\begin{array}{l}\text { Detection } \\
\text { Methods }\end{array}$ & Enhancers & LOD & $\begin{array}{l}\text { Relevant } \\
\text { sample }\end{array}$ & Reference \\
\hline Salmonella enteritidis & Fluorescence & Graphene Oxide & $\begin{array}{l}40 \\
\mathrm{CFU} / \mathrm{mL}\end{array}$ & Milk & {$[177]$} \\
\hline Salmonella enteritidis & $\begin{array}{l}\text { Colorimetric } \\
\text { Lateral flow }\end{array}$ & $\begin{array}{l}\text { Gold } \\
\text { Nanoparticles }\end{array}$ & $\begin{array}{l}10 \\
\mathrm{CFU} / \mathrm{mL}\end{array}$ & $\begin{array}{l}\text { Milk } \\
\text { powder }\end{array}$ & [178] \\
\hline $\begin{array}{l}\text { Salmonella } \\
\text { typhimurium }\end{array}$ & Colorimetric & Silver staining & $7 \mathrm{CFU} / \mathrm{mL}$ & $\begin{array}{l}\text { Lake } \\
\text { water }\end{array}$ & [179] \\
\hline $\begin{array}{l}\text { Salmonella } \\
\text { typhimurium }\end{array}$ & $\begin{array}{l}\text { Electrochemical } \\
\text { Impedance }\end{array}$ & $\begin{array}{l}\text { Graphene oxide, } \\
\text { gold nanoparticles }\end{array}$ & $3 \mathrm{CFU} / \mathrm{mL}$ & Pork & {$[180]$} \\
\hline $\begin{array}{l}\text { Salmonella } \\
\text { typhimurium }\end{array}$ & $\begin{array}{l}\text { Electrochemical } \\
\text { Impedance }\end{array}$ & Gold nanoparticles & $\begin{array}{l}600 \\
\mathrm{CFU} / \mathrm{mL}\end{array}$ & - & [181] \\
\hline $\begin{array}{l}\text { Salmonella } \\
\text { typhimurium }\end{array}$ & $\begin{array}{l}\text { Colorimetric } \\
\text { Enzyme linked } \\
\text { assay }\end{array}$ & Gold nanoparticles & $\begin{array}{l}1000 \\
\mathrm{CFU} / \mathrm{mL}\end{array}$ & Milk & [182] \\
\hline $\begin{array}{l}\text { Vibrio } \\
\text { parahaemolyticus/ } \\
\text { Salmonella } \\
\text { Typhimurium }\end{array}$ & $\begin{array}{l}\text { Fluorescence } \\
\text { Flow cytometry }\end{array}$ & Quantum dots & $\begin{array}{l}5000 \\
\mathrm{CFU} / \mathrm{mL}\end{array}$ & Shrimp & [183] \\
\hline $\begin{array}{l}\text { Salmonella } \\
\text { Typhimurium/ } \\
\text { Staphylococcus aureus }\end{array}$ & Fluorescence & - & $\begin{array}{l}5 \mathrm{CFU} / \mathrm{mL} \\
8 \mathrm{CFU} / \mathrm{mL}\end{array}$ & - & [184] \\
\hline Staphylococcus aureus & $\begin{array}{l}\text { Electrochemical } \\
\text { Impedance }\end{array}$ & $\begin{array}{l}\text { Single wall carbon } \\
\text { nanotubes }\end{array}$ & $\begin{array}{l}800 \\
\mathrm{CFU} / \mathrm{mL}\end{array}$ & Pig skin & [185] \\
\hline Staphylococcus aureus & $\begin{array}{l}\text { Electrochemical } \\
\text { Impedance }\end{array}$ & Graphene oxide & $1 \mathrm{CFU} / \mathrm{mL}$ & - & [186] \\
\hline Staphylococcus aureus & Colorimetric & $\begin{array}{l}\text { Horseradish } \\
\text { peroxidase }\end{array}$ & $9 \mathrm{CFU} / \mathrm{mL}$ & Milk & [187] \\
\hline Group A Streptococcus & $\begin{array}{l}\text { Piezoelectric } \\
\text { quartz crystal }\end{array}$ & $\begin{array}{l}\text { Single wall carbon } \\
\text { nanotubes }\end{array}$ & $\begin{array}{l}12 \\
\mathrm{CFU} / \mathrm{mL}\end{array}$ & Milk & [188] \\
\hline E. coli & $\begin{array}{l}\text { Electrochemical/ } \\
\text { Fluorescence }\end{array}$ & MRE cocktails & $\begin{array}{l}370 \\
\mathrm{CFU} / \mathrm{mL}\end{array}$ & - & [189] \\
\hline $\begin{array}{l}\text { E. coli O157:H7/ } \\
\text { Salmonella } \\
\text { Typhimurium }\end{array}$ & Colorimetric & - & $\begin{array}{l}10000 \\
\mathrm{CFU} / \mathrm{mL}\end{array}$ & - & [190] \\
\hline E. coli 0111 & $\begin{array}{l}\text { Electrochemical } \\
\text { Redox current }\end{array}$ & $\begin{array}{l}\text { Alkaline } \\
\text { phosphatase }\end{array}$ & $\begin{array}{l}305 \\
\mathrm{CFU} / \mathrm{mL}\end{array}$ & Milk & [191] \\
\hline
\end{tabular}




\begin{tabular}{|c|c|c|c|c|c|}
\hline E. coli CECT 675 & $\begin{array}{l}\text { Electrochemical } \\
\text { Impedance }\end{array}$ & $\begin{array}{l}\text { Single wall carbon } \\
\text { nanotubes }\end{array}$ & $\begin{array}{l}6 \mathrm{CFU} / \mathrm{mL} \\
26 \\
\mathrm{CFU} / \mathrm{mL}\end{array}$ & $\begin{array}{l}\text { Milk, } \\
\text { apple } \\
\text { juice }\end{array}$ & [192] \\
\hline $\begin{array}{l}\text { Pseudomonas } \\
\text { aeruginosa }\end{array}$ & Fluorescence & - & $5 \mathrm{CFU} / \mathrm{mL}$ & $\begin{array}{l}\text { Drinking } \\
\text { water }\end{array}$ & [193] \\
\hline $\begin{array}{l}\text { Staphylococcus aureus/ } \\
\text { Vibrio } \\
\text { parahemolyticus/ } \\
\text { Salmonella } \\
\text { Typhimurium }\end{array}$ & Luminescence & $\begin{array}{l}\text { Lanthanide-doped } \\
\text { near infrared to } \\
\text { visible } \\
\text { upconversion } \\
\text { nanoparticles }\end{array}$ & $\begin{array}{l}25 \\
\mathrm{CFU} / \mathrm{mL} \\
10 \\
\mathrm{CFU} / \mathrm{mL} \\
15 \\
\mathrm{CFU} / \mathrm{mL}\end{array}$ & $\begin{array}{l}\text { Milk, } \\
\text { shrimp }\end{array}$ & [194] \\
\hline $\begin{array}{l}\text { Lactobacillus } \\
\text { acidophilus/ } \\
\text { Staphylococcus enteric/ } \\
\text { Staphylococcus aureus }\end{array}$ & $\begin{array}{l}\text { Fluorescence } \\
\text { Microfluidic } \\
\text { biochip }\end{array}$ & - & $\begin{array}{l}11 \\
\mathrm{CFU} / \mathrm{mL} \\
61 \\
\mathrm{CFU} / \mathrm{mL} \\
800 \\
\mathrm{CFU} / \mathrm{mL}\end{array}$ & - & [195] \\
\hline Influenza H5N1 & $\begin{array}{l}\text { Quartz crystal } \\
\text { microbalance }\end{array}$ & Hydrogel & $\begin{array}{l}0.0128 \\
\text { HAU }\end{array}$ & - & [196] \\
\hline Vaccinia virus & $\begin{array}{l}\text { Electrochemical } \\
\text { Impedance }\end{array}$ & - & $\begin{array}{l}60 \\
\text { virions } / \mu \mathrm{L}\end{array}$ & - & [197] \\
\hline Influenza H5N1 & $\begin{array}{l}\text { Surface plasmon } \\
\text { resonance }\end{array}$ & - & $\begin{array}{l}0.128 \\
\text { HAU }\end{array}$ & Poultry & [198] \\
\hline
\end{tabular}

Table 7: Summary table of ssDNA MRE based biosensors for the detection of biological toxins.

\begin{tabular}{llllll}
\hline Target & Detection Methods & Enhancers & LOD & $\begin{array}{l}\text { Relevant } \\
\text { sample }\end{array}$ & $\begin{array}{l}\text { Referenc } \\
\text { e }\end{array}$ \\
\hline Prion protein & Resonance light scattering & $\begin{array}{l}\text { Gold } \\
\text { nanoparticles }\end{array}$ & $\begin{array}{l}0.01 \\
\mathrm{nM}\end{array}$ & Human serum & {$[199]$} \\
$\begin{array}{l}\text { Clostridium } \\
\text { difficile } \\
\text { Toxin A }\end{array}$ & $\begin{array}{l}\text { Electrochemical } \\
\text { Impedance }\end{array}$ & $\begin{array}{l}\text { Horseradish } \\
\text { peroxidase }\end{array}$ & $1 \mathrm{nM}$ & - & {$[200]$} \\
$\begin{array}{l}\text { Staphylococca } \\
\text { l enterotoxin B }\end{array}$ & $\begin{array}{l}\text { Electrochemical } \\
\text { Impedance }\end{array}$ & $\begin{array}{l}\text { Horseradish } \\
\text { peroxidase }\end{array}$ & $\begin{array}{l}0.24 \\
\mathrm{ng} / \mathrm{mL}\end{array}$ & Human serum & [201] \\
$\begin{array}{l}\text { Staphylococca } \\
\text { l enterotoxin B }\end{array}$ & $\begin{array}{l}\text { Surface-enhanced Raman } \\
\text { scattering }\end{array}$ & $\begin{array}{l}\text { Gold } \\
\text { nanoparticles }\end{array}$ & $\begin{array}{l}224 \\
\mathrm{aM}\end{array}$ & $\begin{array}{l}\text { Milk, blood, } \\
\text { urine }\end{array}$ & [202] \\
$\begin{array}{l}\text { E. coli outer } \\
\text { membranes } \\
\text { proteins }\end{array}$ & $\begin{array}{l}\text { Evanescent wave fiber } \\
\text { optic }\end{array}$ & - & $0.1 \mathrm{nM}$ & $\begin{array}{l}\text { Environmenta } \\
\text { l water }\end{array}$ & [203] \\
\hline
\end{tabular}




\begin{tabular}{|c|c|c|c|c|c|}
\hline $\begin{array}{l}\text { E. coli outer } \\
\text { membranes } \\
\text { proteins }\end{array}$ & $\begin{array}{l}\text { Electrochemical } \\
\text { Impedance }\end{array}$ & - & $\begin{array}{l}100 \\
\mathrm{nM}\end{array}$ & $\begin{array}{l}\text { Environmenta } \\
\text { l water }\end{array}$ & [204] \\
\hline $\begin{array}{l}\text { Botulinum } \\
\text { neurotoxin, } \\
\text { type A }\end{array}$ & $\begin{array}{l}\text { Electrochemical } \\
\text { Redox current }\end{array}$ & $\begin{array}{l}\text { Horseradish } \\
\text { peroxidase }\end{array}$ & $\begin{array}{l}40 \\
\mathrm{pg} / \mathrm{mL}\end{array}$ & - & [205] \\
\hline Aflatoxin B1 & RT-qPCR & - & $\begin{array}{l}25 \\
\mathrm{fg} / \mathrm{mL}\end{array}$ & $\begin{array}{l}\text { Chinese wild } \\
\text { rye hay, infant } \\
\text { rice cereal }\end{array}$ & [206] \\
\hline Aflatoxin B1 & $\begin{array}{l}\text { Fluorescence } \\
\text { Dipstick }\end{array}$ & - & $\begin{array}{l}0.3 \\
\mathrm{ng} / \mathrm{g}\end{array}$ & Corn & [207] \\
\hline Aflatoxin M1 & $\begin{array}{l}\text { Electrochemical } \\
\text { Redox current }\end{array}$ & $\begin{array}{l}\text { Magnetic } \\
\text { nanoparticles }\end{array}$ & $8 \mathrm{ng} / \mathrm{L}$ & Milk & [208] \\
\hline Ochratoxin A & Colorimetric & - & $20 \mathrm{nM}$ & - & [209] \\
\hline Ochratoxin A & $\begin{array}{l}\text { Electrochemical } \\
\text { Impedance }\end{array}$ & $\begin{array}{l}\text { Graphene oxide, } \\
\text { gold nanoparticles }\end{array}$ & $\begin{array}{l}0.74 \\
\mathrm{pM}\end{array}$ & Red wine & [210] \\
\hline Ochratoxin A & Fluorescence & - & $\begin{array}{l}1 \\
\mathrm{ng} / \mathrm{mL}\end{array}$ & Beer & [211] \\
\hline Ochratoxin A & $\begin{array}{l}\text { Electrochemical } \\
\text { Redox current }\end{array}$ & $\begin{array}{l}\text { Gold } \\
\text { nanoparticles }\end{array}$ & $\begin{array}{l}0.75 \\
\mathrm{pM}\end{array}$ & Red wine & [212] \\
\hline Ochratoxin A & $\begin{array}{l}\text { Electrochemiluminescenc } \\
\text { e }\end{array}$ & $\begin{array}{l}\text { Loop-mediated } \\
\text { isothermal } \\
\text { amplification }\end{array}$ & $10 \mathrm{fM}$ & Red wine & [213] \\
\hline Ochratoxin A & Fluorescence & - & $\begin{array}{l}2 \mathrm{pg} / \\
\mathrm{mL}\end{array}$ & Wheat & [214] \\
\hline Ochratoxin A & $\begin{array}{l}\text { Localized surface } \\
\text { plasmon resonance }\end{array}$ & - & $1 \mathrm{nM}$ & Corn powder & [215] \\
\hline Ochratoxin A & RT-qPCR & - & $\begin{array}{l}1 \\
\mathrm{fg} / \mathrm{mL}\end{array}$ & Red wine & [216] \\
\hline Ochratoxin A & Fluorescence & - & $\begin{array}{l}0.2 \\
\mathrm{ng} / \mathrm{mL}\end{array}$ & Red wine & [217] \\
\hline Ochratoxin A & Chemiluminescence & $\begin{array}{l}\text { Nicking } \\
\text { endonuclease }\end{array}$ & $\begin{array}{l}0.3 \\
\mathrm{pg} / \mathrm{mL}\end{array}$ & Wheat & [218] \\
\hline Ochratoxin A & $\begin{array}{l}\text { Electrochemical } \\
\text { Impedance }\end{array}$ & - & $\begin{array}{l}0.25 \\
\mathrm{ng} / \mathrm{mL}\end{array}$ & Beer & [219] \\
\hline Ochratoxin A & $\begin{array}{l}\text { Electrochemical } \\
\text { Redox current }\end{array}$ & - & $\begin{array}{l}0.1 \\
\mathrm{ng} / \mathrm{mL}\end{array}$ & Beer & [220] \\
\hline Ochratoxin A & $\begin{array}{l}\text { Electrochemical } \\
\text { Impedance }\end{array}$ & - & $\begin{array}{l}0.12 \\
\mathrm{ng} / \mathrm{mL}\end{array}$ & Beer & [221] \\
\hline Ochratoxin A & $\begin{array}{l}\text { Electrochemical } \\
\text { Differential pulse } \\
\text { voltametry }\end{array}$ & $\begin{array}{l}\text { Horseradish } \\
\text { peroxidase, } \\
\text { alkaline } \\
\text { phosphatase, } \\
\text { superparamagneti } \\
\text { c nanoparticles }\end{array}$ & $\begin{array}{l}0.15 \\
\mathrm{ng} / \mathrm{mL}\end{array}$ & Red wine & [222] \\
\hline Ochratoxin A & $\begin{array}{l}\text { Electrochemical } \\
\text { Flow-based }\end{array}$ & - & $\begin{array}{l}0.05 \\
\mu g / L\end{array}$ & Beer & [223] \\
\hline Ochratoxin A & Colorimetric & Gold & 1 & Red wine & [224] \\
\hline
\end{tabular}




\begin{tabular}{|c|c|c|c|c|c|}
\hline & Lateral flow & nanoparticles & $\begin{array}{l}\mathrm{ng} / \mathrm{mL} \\
, 0.18 \\
\mathrm{ng} / \mathrm{mL}\end{array}$ & & \\
\hline Ochratoxin A & $\begin{array}{l}\text { Fluorescence } \\
\text { Lateral flow }\end{array}$ & Quantum dots & $\begin{array}{l}1.9 \\
\mathrm{ng} / \mathrm{mL}\end{array}$ & Red wine & [225] \\
\hline Ochratoxin A & $\begin{array}{l}\text { Electrochemical } \\
\text { Electric current }\end{array}$ & $\begin{array}{l}\text { Horseradish } \\
\text { peroxidase }\end{array}$ & $\begin{array}{l}0.07 \pm \\
0.01 \\
\mathrm{ng} / \mathrm{mL}\end{array}$ & Wheat & [226] \\
\hline Ochratoxin A & $\begin{array}{l}\text { Electrochemical } \\
\text { Redox current }\end{array}$ & $\begin{array}{l}\text { Gold } \\
\text { nanoparticles }\end{array}$ & $\begin{array}{l}30 \\
\mathrm{pg} / \mathrm{mL}\end{array}$ & Red wine & [227] \\
\hline Ochratoxin A & $\begin{array}{l}\text { Electrochemical } \\
\text { Impedance }\end{array}$ & $\begin{array}{l}\text { Horseradish } \\
\text { peroxidase }\end{array}$ & $\begin{array}{l}0.4 \\
\mathrm{pg} / \mathrm{mL}\end{array}$ & Wheat & [228] \\
\hline Ochratoxin A & $\begin{array}{l}\text { Electrochemical } \\
\text { Redox current }\end{array}$ & - & $\begin{array}{l}0.095 \\
\mathrm{pg} / \mathrm{mL}\end{array}$ & Red wine & [229] \\
\hline Ochratoxin A & Chemiluminescence & $\begin{array}{l}\text { Upconversion } \\
\text { nanoparticles }\end{array}$ & $\begin{array}{l}0.1 \\
\mathrm{pg} / \mathrm{mL}\end{array}$ & Maize & [230] \\
\hline Ochratoxin A & $\begin{array}{l}\text { Electrochemical } \\
\text { Impedance }\end{array}$ & $\begin{array}{l}\text { Silver } \\
\text { nanoparticles }\end{array}$ & $\begin{array}{l}0.05 \\
\mathrm{nM}\end{array}$ & Beer & [231] \\
\hline Ochratoxin A & $\begin{array}{l}\text { Electrochemical } \\
\text { Impedance }\end{array}$ & $\begin{array}{l}\text { Loop-mediated } \\
\text { isothermal }\end{array}$ & $0.3 \mathrm{pM}$ & Red wine & [232] \\
\hline Ochratoxin A & Fluorescence & - & $\begin{array}{l}0.8 \\
\mathrm{ng} / \mathrm{mL}\end{array}$ & Corn & [233] \\
\hline Ochratoxin A & Fluorescence & $\begin{array}{l}\text { Single-stranded } \\
\text { signal probes }\end{array}$ & $\begin{array}{l}20 \\
\mathrm{pg} / \mathrm{mL}\end{array}$ & Wheat & [234] \\
\hline Ochratoxin A & Fluorescence & Terbium & $\begin{array}{l}0.08- \\
5.42 \\
\mathrm{ng} / \mathrm{mL}\end{array}$ & Wheat & [235] \\
\hline Ochratoxin A & $\begin{array}{l}\text { Electrochemical } \\
\text { Impedance }\end{array}$ & Redox probe & $\begin{array}{l}0.12- \\
0.4 \mathrm{nM}\end{array}$ & $\begin{array}{l}\text { Coffee, flour, } \\
\text { wine }\end{array}$ & [236] \\
\hline Ochratoxin A & $\begin{array}{l}\text { Fluorescence resonance } \\
\text { energy transfer }\end{array}$ & - & $\begin{array}{l}2 \\
\mathrm{pg} / \mathrm{mL}\end{array}$ & Maize Flour & [237] \\
\hline Ochratoxin A & $\begin{array}{l}\text { Electrochemical } \\
\text { Redox current }\end{array}$ & $\begin{array}{l}\text { Exonuclease } \\
\text { digestion }\end{array}$ & $\begin{array}{l}1.0 \\
\mathrm{pg} / \mathrm{mL}\end{array}$ & Wheat starch & [238] \\
\hline Ochratoxin A & $\begin{array}{l}\text { Electrochemical } \\
\text { Electric current }\end{array}$ & $\begin{array}{l}\text { Rolling circle } \\
\text { amplification }\end{array}$ & $\begin{array}{l}0.2 \\
\mathrm{pg} / \mathrm{mL}\end{array}$ & Red wine & [239] \\
\hline Ochratoxin A & Fluorescence & - & $\begin{array}{l}21.8 \\
\mathrm{nM}\end{array}$ & Red Wine & [240] \\
\hline Ochratoxin A & $\begin{array}{l}\text { Electrochemiluminescenc } \\
\mathrm{e}\end{array}$ & $\begin{array}{l}\text { Gold } \\
\text { nanoparticles }\end{array}$ & $\begin{array}{l}0.007 \\
\mathrm{ng} / \mathrm{mL}\end{array}$ & Wheat & [241] \\
\hline Ochratoxin A & Colorimetric & - & $2.5 \mathrm{nM}$ & Red wine & [242] \\
\hline Ochratoxin A & Colorimetric & - & $4 \mathrm{nM}$ & Red wine & [243] \\
\hline Ochratoxin A & Fluorescence & - & $\begin{array}{l}24.1 \\
\mathrm{nM}\end{array}$ & Beer & [244] \\
\hline Ochratoxin A & $\begin{array}{l}\text { Electrochemical } \\
\text { Impedance }\end{array}$ & - & $\begin{array}{l}0.1 \\
\mathrm{ng} / \mathrm{mL}\end{array}$ & - & [245] \\
\hline Ochratoxin A & Fluorescence & - & $\begin{array}{l}0.01 \\
\mathrm{ng} / \mathrm{mL}\end{array}$ & Maize Flour & [246] \\
\hline
\end{tabular}


Table 1.8: Summary table of ssDNA MREs based biosensors for the detection of chemical toxins.

\begin{tabular}{|c|c|c|c|c|c|}
\hline Target & Detection Methods & Enhancers & LOD & $\begin{array}{l}\begin{array}{l}\text { Relevant } \\
\text { sample }\end{array} \\
\end{array}$ & Reference \\
\hline Bisphenol A & $\begin{array}{l}\text { Fiber optic } \\
\text { Fluorescence }\end{array}$ & - & $\begin{array}{l}1.86 \\
\mathrm{nM}\end{array}$ & Wastewater & [247] \\
\hline Bisphenol A & $\begin{array}{l}\text { Resonance light } \\
\text { scattering }\end{array}$ & $\begin{array}{l}\text { Gold } \\
\text { nanoparticles }\end{array}$ & $\begin{array}{l}0.012- \\
0.28 \\
\mathrm{ng} / \mathrm{mL}\end{array}$ & $\begin{array}{l}\text { Supermarket } \\
\text { ticket }\end{array}$ & [248] \\
\hline Bisphenol A & $\begin{array}{l}\text { Electrochemical } \\
\text { Redox current }\end{array}$ & $\begin{array}{l}\text { Gold } \\
\text { nanoparticles } \\
\text { dotted graphene }\end{array}$ & $5 \mathrm{nM}$ & Milk & [249] \\
\hline Bisphenol A & $\begin{array}{l}\text { Colorimetric/ } \\
\text { Fluorescent }\end{array}$ & - & $\begin{array}{l}0.1 \\
\mathrm{ng} / \mathrm{mL} \\
0.01 \\
\mathrm{pg} / \mathrm{mL}\end{array}$ & Water & [250] \\
\hline Bisphenol A & Colorimetric & - & $\begin{array}{l}0.1 \\
\mathrm{ng} / \mathrm{mL}\end{array}$ & Tap water & [251] \\
\hline Bisphenol A & $\begin{array}{l}\text { Colorimetric } \\
\text { Lateral Flow }\end{array}$ & $\begin{array}{l}\text { Gold } \\
\text { nanoparticles }\end{array}$ & $\begin{array}{l}76 \\
\mathrm{pg} / \mathrm{mL}\end{array}$ & Tap water & [252] \\
\hline Bisphenol A & $\begin{array}{l}\text { Resonance Rayleigh } \\
\text { scattering }\end{array}$ & $\begin{array}{l}\text { Gold } \\
\text { nanoparticles }\end{array}$ & $\begin{array}{l}83 \\
\mathrm{pg} / \mathrm{mL}\end{array}$ & Tap water & [253] \\
\hline Bisphenol A & $\begin{array}{l}\text { Electrochemcial } \\
\text { Electric current }\end{array}$ & $\begin{array}{l}\text { Single walled } \\
\text { carbon } \\
\text { nanotubes field } \\
\text { effect transistor }\end{array}$ & $\begin{array}{l}10 \mathrm{fM} \\
\text { to } 1 \mathrm{pM}\end{array}$ & & [254] \\
\hline Bisphenol A & Plasmonic chirality & - & $\begin{array}{l}8 \\
\mathrm{pg} / \mathrm{mL}\end{array}$ & Tap water & [255] \\
\hline 17ß-estradiol (E2) & Photoelectrochemical & $\begin{array}{l}\text { Titanium oxide } \\
\text { nanotubes } \\
\text { arrays }\end{array}$ & $33 \mathrm{fm}$ & $\begin{array}{l}\text { Medical waste } \\
\text { water, lake } \\
\text { water, tap } \\
\text { water }\end{array}$ & [256] \\
\hline 17ß-estradiol (E2) & $\begin{array}{l}\text { Electrochemical } \\
\text { Impedance }\end{array}$ & - & $2.0 \mathrm{pM}$ & Human urine & [257] \\
\hline 17ß-estradiol (E2) & Fluorescence & - & $2.1 \mathrm{nM}$ & Wastewater & [258] \\
\hline Acetamiprid & Colorimetric & - & $5 \mathrm{nM}$ & Soil & [259] \\
\hline Acetamiprid & $\begin{array}{l}\text { Electrochemical } \\
\text { Impedance }\end{array}$ & $\begin{array}{l}\text { Gold } \\
\text { nanoparticles }\end{array}$ & $1 \mathrm{nM}$ & $\begin{array}{l}\text { Waste water, } \\
\text { tomatoes }\end{array}$ & [260] \\
\hline $\begin{array}{l}4 \text { organophosphorus } \\
\text { pesticides } \\
\text { phorate, profenofos, } \\
\text { isocarbophos, and } \\
\text { omethoate }\end{array}$ & $\begin{array}{l}\text { Fluorescence } \\
\text { Polarization }\end{array}$ & - & $\begin{array}{l}19.2, \\
13.4, \\
17.2, \\
23.4 \\
\mathrm{nM}\end{array}$ & $\begin{array}{l}\text { Chinese } \\
\text { cabbage }\end{array}$ & [176] \\
\hline
\end{tabular}




\subsubsection{Electrical/ Electrochemical}

The principle of electrochemical detection is based on measuring changes in electrical properties of the sensing platform. In this method, ssDNA MRE is usually immobilized on a gold electrode via thiol-gold linkage. A redox label, such as methylene blue can be used to detect binding between MRE and the target [261]. In a "signal on" system, the redox label is away from the electrode surface, and the binding of target causes a conformational change in the MRE, and brings the redox label into close proximity with the electrode, thus causing a measurable change in electrical properties (Figure 1.2). A "signal off” system behaves similarly, but the binding of target causes the redox label move away from the electrode. This system can also be modified as a "label-free" system, in which the redox molecule is intercalated in a hairpin structure of a MRE in a target unbound state, and binding of the target causes the release of the redox molecule (Figure 1.2). In addition to measuring redox current, the changes in impedance upon binding of the target can also be measured. In this case, no labeling of MRE is required and the conformational changes in MRE upon target binding causes a measurable change in impedance that can be recorded by voltammetry [226]. 
(A)
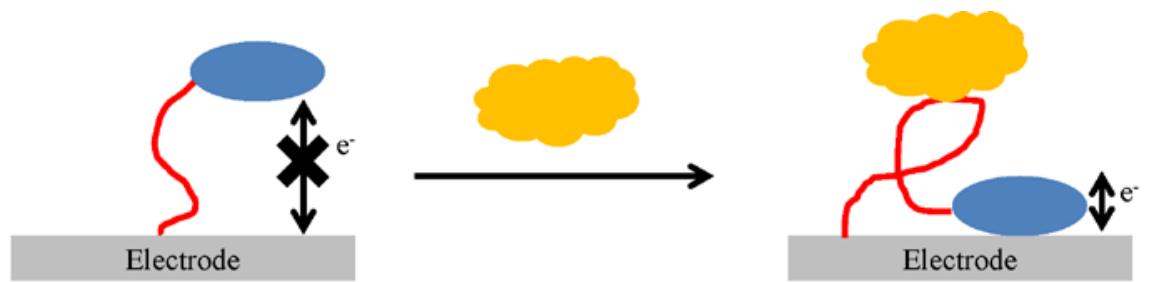

(B)
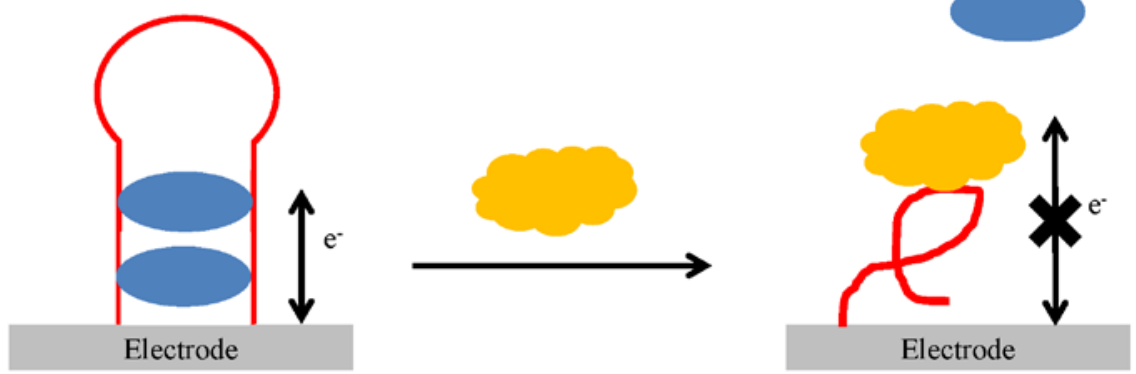

Target

$\frown$ MRE

Redox label, such as methylene blue

(C)
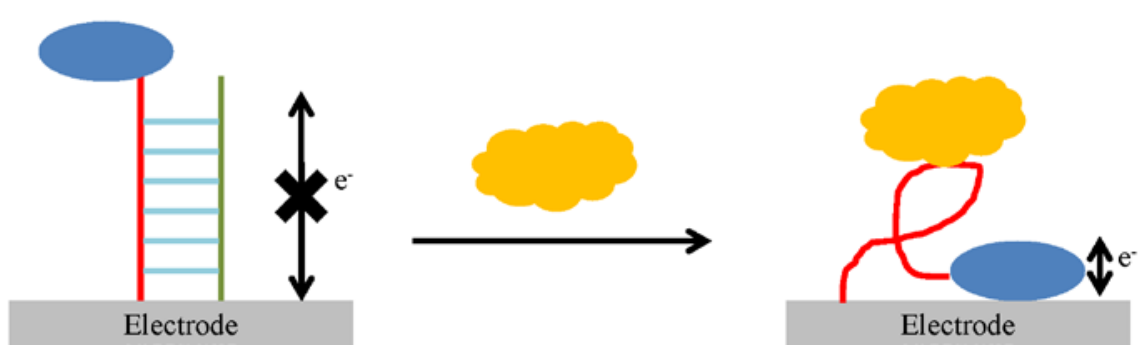

Figure 1.2: Illustration of examples of ssDNA MRE based electrochemical biosensors. (A) A representation of an "on-mode” system using a redox label for current transduction. (B) A representation of a "label-free” system by intercalating a redox label in a hairpin structure. (C) A representation of an "on-mode” system by hybridization with the complementary sequence.

Nanomaterials can also be incorporated into electrochemical sensor to enhance signals. Single-walled carbon nanotube field effect transistors (SWCNT-FET) can be used to build electrochemical biosensors (Figure 1.3). In this system, MREs are immobilized on SWCNTs and SWCNTs are sandwiched between a source and a drain electrode. When the immobilized MREs bind to the target, there is a measurable change in the conductance of the system [254]. Gold nanoparticles (AuNP) are also widely used as signal enhancers. AuNPs can be coated on 
electrodes and greatly increase the surface area. As a result, more MREs can be immobilized on the electrode, and thus enhancing the system's sensitivity. AuNPs can also be coated with a second MRE and reporting probes in a sandwich assay (Figure 1.3). In this case, the target first binds to a primary capturing MRE, followed by the binding a secondary reporting MRE along with a redox molecule, which can generate an enhanced signal for sensitive detection [262].

(4)
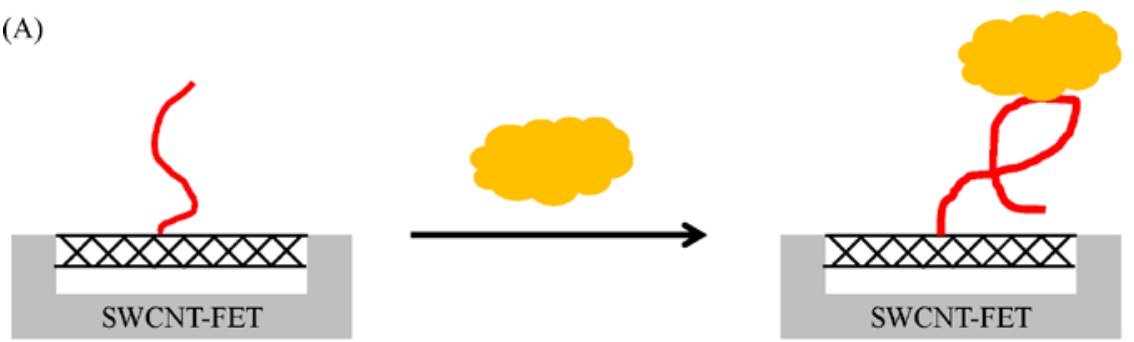

(B)
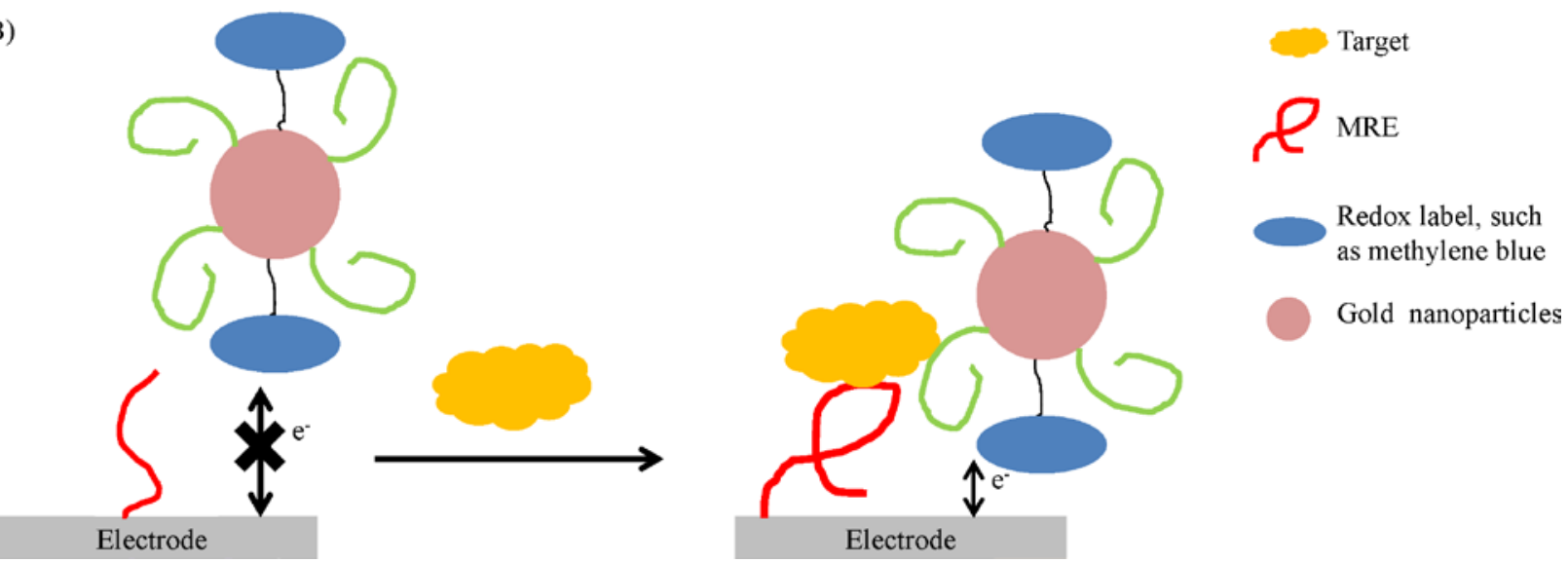

Figure 1.3: Illustration of examples of signal enhancement methods in ssDNA MRE based

electrochemical biosensors. (A) A representation of a single-walled carbon nanotubes field effect transistors. (B) A representation of gold nanoparticles carrying redox labels in a sandwich detection style.

\subsubsection{Optical}

Optical detection methods can be classified into three major categories. 1) Fluorescence detection, which require specialized instruments to measure fluorescent signals. 2) Colorimetric 
detection, which color changes can be observed by the naked eye or measured in terms of optical density. 3) Absorbance assay can enhance detection signals, and subsequently be measured by instruments as well.

\subsubsection{Fluorescence}

The principle of fluorescence detection is based upon the generation or quenching of fluorescence signals upon target binding. Various fluorescence molecules and quantum dots can be linked to ssDNA MREs. Conformational changes induced by target binding can alter the fluorescence signal generated by the fluorophore, and therefore can be measured (Figure 1.4) [263]. Quenching molecules can also be linked to the other end of the ssDNA MRE. In this system, the quencher completely blocks the fluorescence signal from the fluorophore and target binding can move the quencher away from the fluorophore, and have "signal on" detection (Figure 1.4) [264]. The same principle can also be applied for a "signal off" system. Carbon nanotubes and graphene can also be used as quenchers, which fluorescent labeled ssDNA MREs is adsorbed on the carbon quenchers via $\pi-\pi$ stacking interactions. Fluorescence resonance energy transfer (FRET) can also be utilized as measurements when the distance of the two fluorescence molecules linked to MREs is changed upon target binding. 
(A)
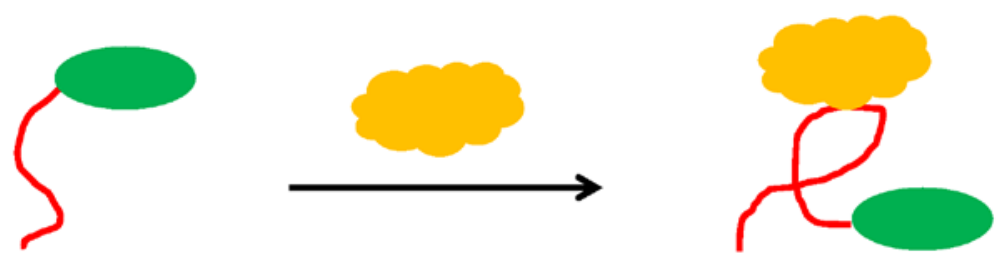

(B)

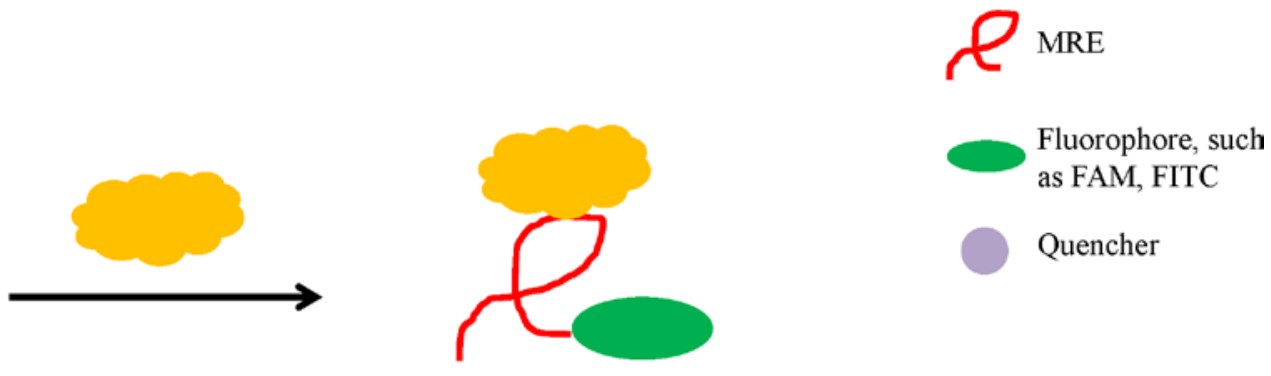

Figure 1.4: Illustration of examples of ssDNA MRE based fluorescent biosensors. (A) A representation of the changes in fluorescent signal upon target binding to a fluorophore labeled MRE. (B) A representation of an "on-mode" system by using a quencher labeled on the complementary sequence.

\subsubsection{Colorimetric}

Gold nanoparticles (AuNP) have been widely used in various colorimetric assays. AuNPs aggregate in salt solution and appear in purple color. When they are dispersed, they are in red color. This special absorbance property of AuNPs allows observation of target binding by naked eye. MREs in salt solution can bind to AuNPs and dispersing the AuNPs. When targets are introduced into the system, MRE preferably bind to the targets, and therefore causing AuNPs to aggregate, a red to purple color change is observed (Figure 1.5) [265]. Alternatively, ssDNA MREs can be used to link AuNPs that are functionalized with probe strands. In this case, the initial state of the MRE/AuNPs solution is aggregated purple. Upon target binding, the linked AuNPs are released, and a purple to red color change is observed (Figure 1.5) [266]. Furthermore, AuNPs can be used in a sandwich colorimetric assay, in which the secondary reporting MRE 
linked AuNP can grow in size when the detection system is placed in a growth solution containing $\mathrm{HAuCl}_{4}$, and thus enhancing the detection limit [267].

(A)
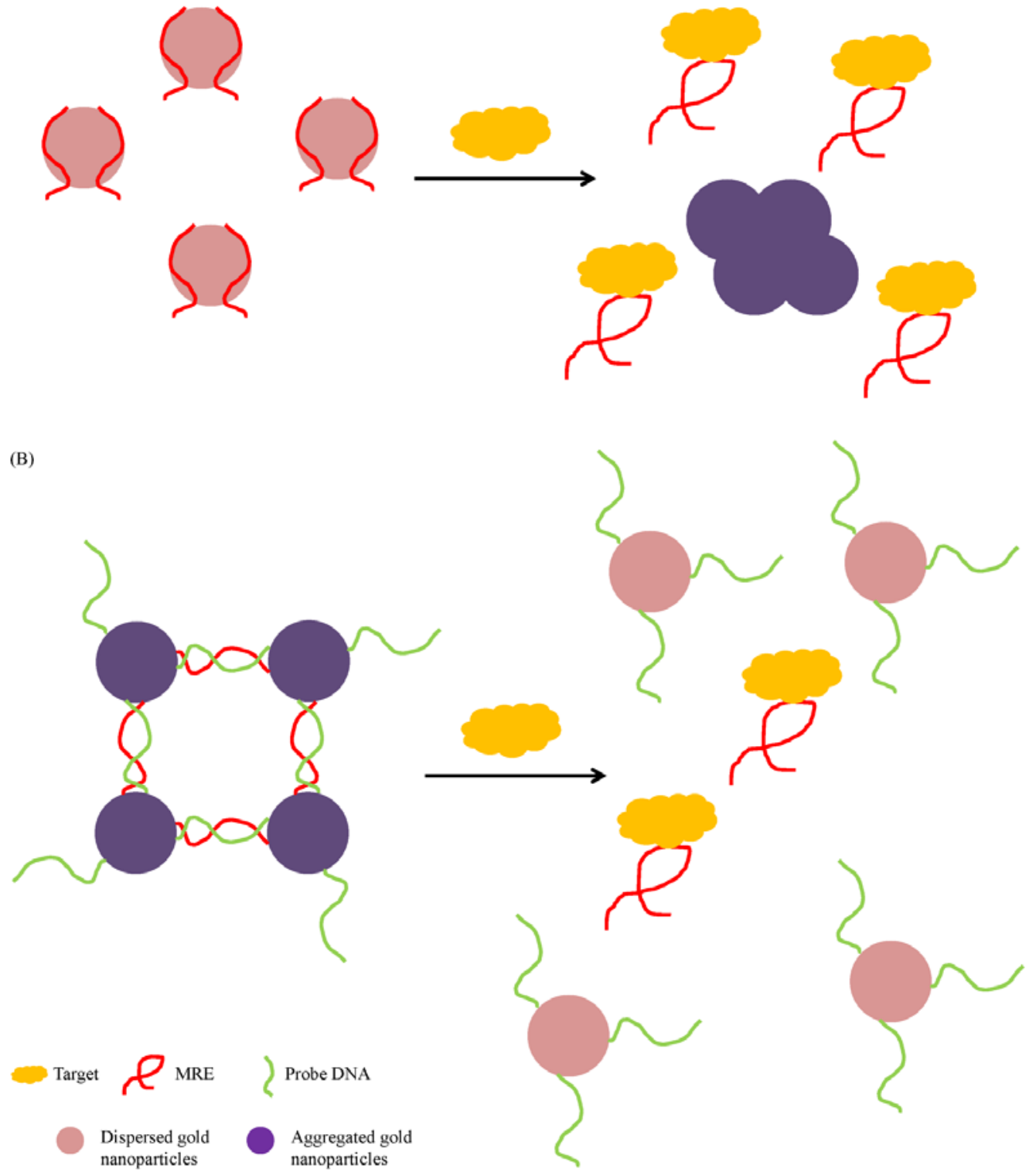

Figure 1.5: Illustration of examples of ssDNA MRE based colorimetric biosensors. (A) A representation of a colorimetric assay using MRE dispersed gold nanoparticles. (B) A representation of a colorimetric assay using cross-linked gold nanoparticles aggregates via MRE and probe DNA. 


\subsubsection{Absorbance}

Nucleic acid MREs have been used in modified enzyme linked immunoassays, usually substituting for either the capturing or the reporter antibodies. In a direct oligonucleotide enzyme link assay, often the protein target is adsorbed on plate and biotinylated MREs bind to the target, and then followed by the addition of streptavidin-horse radish peroxidase (HRP) conjugate and enzyme substrate for signal development [138]. In a sandwich assay, biotinylated MREs can be immobilized on streptavidin plate, and then followed by the addition of the protein target, HPR linked antibody, and enzyme substrate [96]. This detection method however is mostly limited to protein targets, and the availability of specific antibodies (Figure 1.6).

(A)

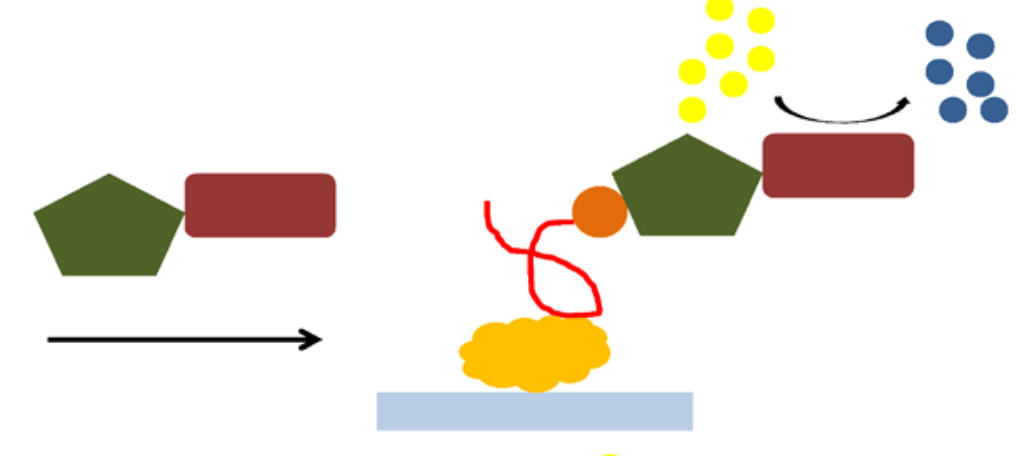

(B)
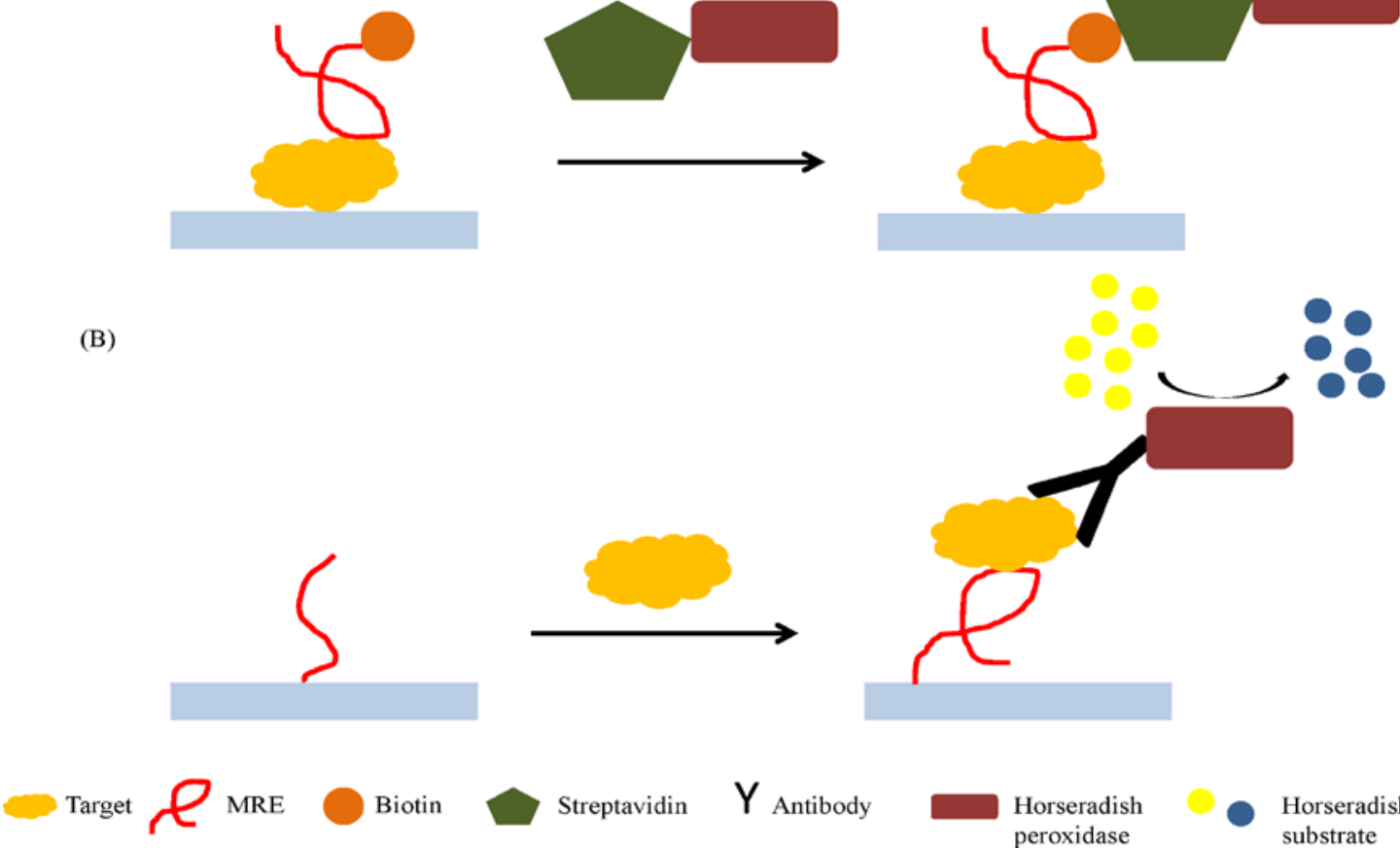

Streptavidin $Y_{\text {Antibody }}$

Horseradish peroxidase

Horseradish peroxidase substrate

Figure 1.6: Illustration of examples of ssDNA MRE modified enzyme linked assays. (A) a representation of a direct MREs modified enzyme linked assay with MRE as the reporter. (B) A 
representation of an indirect MREs modified enzyme linked assay with MRE as the target capturing element.

\subsubsection{Mass Sensitive}

Mass sensitive detection is a class of label-free detection system that can be sub-divided into four major categories: 1) Surface Plasmon Resonance (SPR), 2) Quartz Crystal Microbalance (QCM), 3) Surface Acoustic Wave (SAW) and 4) Micromechanical cantilever. None of these detection systems require additional labeling.

Surface plasmon resonance (SPR) sensors measure a change in the refractive index and resonance angle when a mass change occurs upon target binding. MREs are often biotin-tagged and immobilized on streptavidin coated gold chip. When targets in solution pass through the flow cell, the binding between targets and immobilized MREs cause a change in mass on the sensor chip surface, and is subsequently translated into a change in the refractive index. This change in resonance is proportional to the amount of target bound to the immobilized MREs, and therefore providing a real-time detection of the target in solution (Figure 1.7) [198]. 

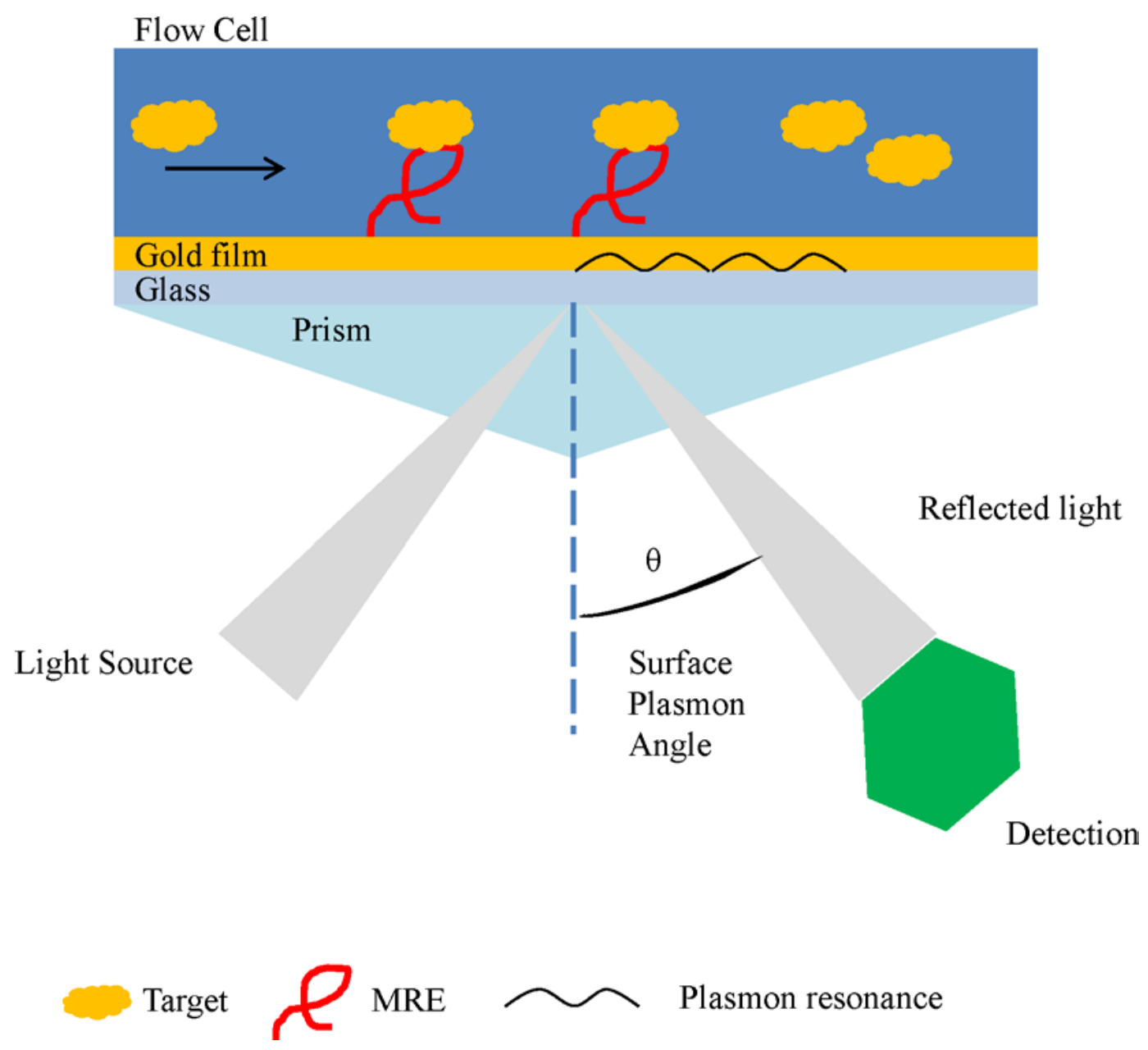

Figure 1.7: Illustration of ssDNA MRE based surface plasmon resonance biosensors. When targets bind to immobilized MREs, a change in the plasmon resonance and plasmon angle will be detected and translated into a real-time response unit.

A Quartz crystal microbalance (QCM) is an acoustic wave resonator based on the piezoelectric property of quartz crystal. Nucleic acid MREs can be immobilized on gold-coated quartz. The binding between target and MRE increases the mass on the surface of the crystal and leads to a detectable decrease in the resonance frequency of the crystal (Figure 1.8) [196]. The detection principle of surface acoustic wave (SAW) based biosensor is similar to QCM. Nucleic acid MREs have been utilized to fabricate a special type of Love-wave sensor that uses shear 
horizontal waves to enhance the surface sensitivity, and achieve ultra-sensitive detection of the target [268].

Micromechanical cantilevers have been investigated for MRE based biosensors. The major advantage of this type of sensor is that it can be readily scale up and perform parallel analysis for multiple analytes with low background interference [269]. When the target binds to the MRE on the surface of the cantilever, a nanometer scale deflection in the cantilever can be detected optically (Figure 1.8).

(A)
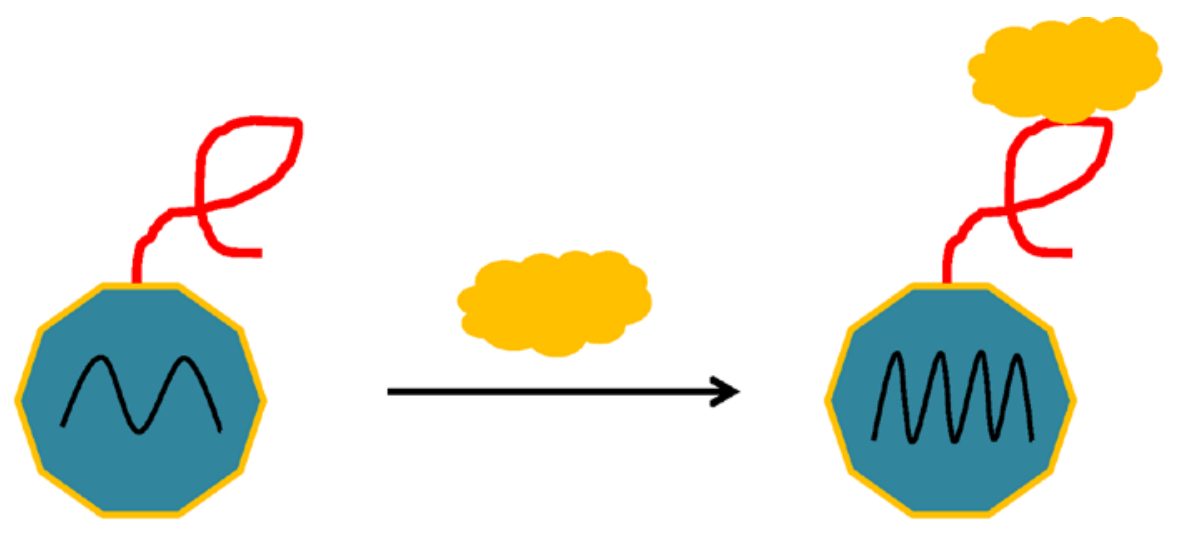

(B)
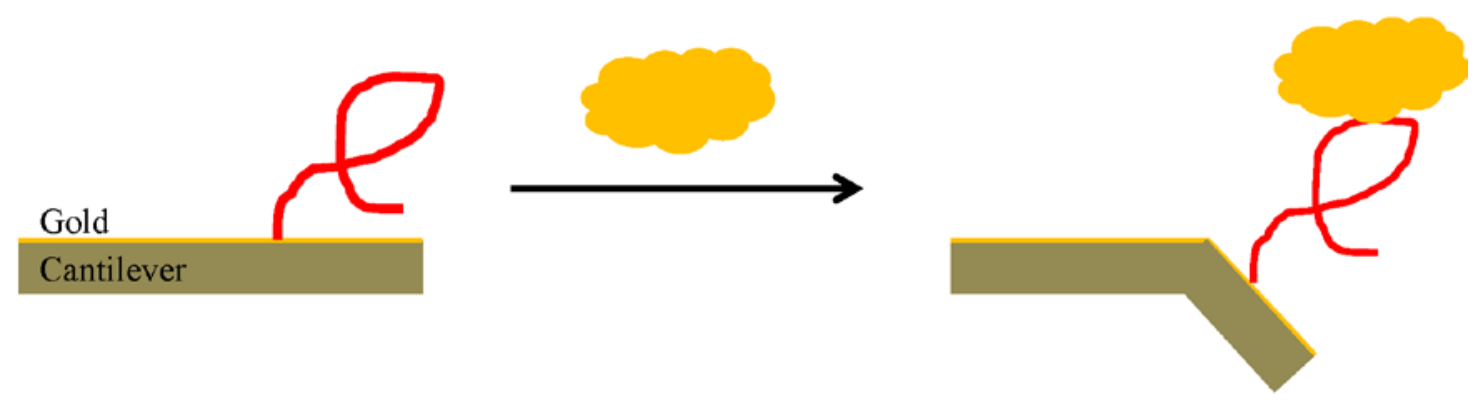

Target

$\overbrace{\text { MRE }}$

Gold coated quartz

$\bigcap$ Resonance frequency 
Figure 1.8: Illustration of examples of ssDNA MRE based mass sensitive biosensors. (A) A representation of a detectable change in resonance frequency upon target binding to immobilized MRE on quartz crystal micro balance. (B) Representation of a detectable nanometer scale bending upon target binding to immobilized MRE on micromechanical cantilever.

\subsection{Conclusion and Future Perspectives}

Over the last two decades, there has been a continuous increase in the research of molecular recognition elements. Single-stranded DNA MREs have several advantages over antibodies, in terms of stability, reusability, and production cost. However, ssDNA MREs are not without limitations. The binding affinity of MREs is highly dependent on their three dimensional structure and is influenced by factors including the ionic condition, temperature, and $\mathrm{pH}$ of the binding condition [4]. Challenges remain in eliminating cross binding activities to other molecules in native environments. These limitations hinder the use of MRE for detection in many real world complex samples, such as biological fluids and food matrices. A carefully designed selection scheme can greatly improve the specificity of the identified MRE, which can better distinguish closely related molecules at low concentrations. Using modified bases in PCR amplification or performing base modifications after selection can also help improving resistance to nucleases in many biological fluids, such as human serum [270]. The overall attractive features of ssDNA MREs prompt researchers continue to investigate and optimize their applications in biosensing. 


\subsection{References}

1. Tuerk, C. and L. Gold, Systematic evolution of ligands by exponential enrichment: RNA ligands to bacteriophage T4 DNA polymerase. Science, 1990. 249(4968): p. 505-10.

2. Jayasena, S.D., Aptamers: an emerging class of molecules that rival antibodies in diagnostics. Clin Chem, 1999. 45(9): p. 1628-50.

3. Hall, B., et al., Design, synthesis, and amplification of DNA pools for in vitro selection. Curr Protoc Nucleic Acid Chem, 2009. Chapter 9: p. Unit 92.

4. $\quad$ Patel, D.J., et al., Structure, recognition and adaptive binding in RNA aptamer complexes. J Mol Biol, 1997. 272(5): p. 645-64.

5. Potty, A.S., et al., Biophysical characterization of DNA and RNA aptamer interactions with hen egg lysozyme. Int J Biol Macromol, 2011. 48(3): p. 392-7.

6. de-los-Santos-Álvarez, N., et al., Modified-RNA Aptamer-Based Sensor for Competitive Impedimetric Assay of Neomycin B. J Am Chem Soc, 2007. 129(13): p. 3808-3809.

7. Cui, Y., H. Ulrich, and G.P. Hess, Selection of 2'-fluoro-modified RNA aptamers for alleviation of cocaine and MK-801 inhibition of the nicotinic acetylcholine receptor. $\mathrm{J}$ Membr Biol, 2004. 202(3): p. 137-49.

8. $\quad$ You, K., et al., Aptamers as functional nucleic acids:In vitro selection and biotechnological applications. Biotechnology and Bioprocess Engineering, 2003. 8(2): p. 64-75.

9. Rotherham, L.S., et al., Selection and application of ssDNA aptamers to detect active TB from sputum samples. PLoS One, 2012. 7(10): p. e46862.

10. Cho, S.J., et al., Novel system for detecting SARS coronavirus nucleocapsid protein using an ssDNA aptamer. J Biosci Bioeng, 2011. 112(6): p. 535-40.

11. DeGrasse, J.A., A single-stranded DNA aptamer that selectively binds to Staphylococcus aureus enterotoxin B. PLoS One, 2012. 7(3): p. e33410.

12. Eissa, S., et al., Selection and identification of DNA aptamers against okadaic acid for biosensing application. Anal Chem, 2013. 85(24): p. 11794-801.

13. McKeague, M., et al., Screening and initial binding assessment of fumonisin $b(1)$ aptamers. Int J Mol Sci, 2010. 11(12): p. 4864-81.

14. Williams, R.M., et al., In vitro selection of a single-stranded DNA molecular recognition element against atrazine. Int J Mol Sci, 2014. 15(8): p. 14332-47.

15. Williams, R.M., E. Maher, and L.J. Sooter, In Vitro Selection of a Single-Stranded DNA Molecular Recognition Element for the Pesticide Malathion. Comb Chem High Throughput Screen, 2014.

16. Williams, R.M., et al., In vitro selection of a single-stranded DNA molecular recognition element specific for bromacil. J Nucleic Acids, 2014. 2014: p. 102968.

17. Gyllensten, U.B. and H.A. Erlich, Generation of single-stranded DNA by the polymerase chain reaction and its application to direct sequencing of the HLA-DQA locus. Proc Natl Acad Sci U S A, 1988. 85(20): p. 7652-6.

18. Hultman, T., et al., Direct solid phase sequencing of genomic and plasmid DNA using magnetic beads as solid support. Nucleic Acids Res, 1989. 17(13): p. 4937-46.

19. Kujau, M.J. and S. Wolfl, Efficient preparation of single-stranded DNA for in vitro selection. Mol Biotechnol, 1997. 7(3): p. 333-5. 
20. Walder, R.Y., J.R. Hayes, and J.A. Walder, Use of PCR primers containing a 3'-terminal ribose residue to prevent cross-contamination of amplified sequences. Nucleic Acids Res, 1993. 21(18): p. 4339-43.

21. Mendonsa, S.D. and M.T. Bowser, In vitro selection of high-affinity DNA ligands for human IgE using capillary electrophoresis. Anal Chem, 2004. 76(18): p. 5387-92.

22. Berezovski, M., et al., Nonequilibrium capillary electrophoresis of equilibrium mixtures: a universal tool for development of aptamers. J Am Chem Soc, 2005. 127(9): p. 3165-71.

23. Park, J.W., et al., Immobilization-free screening of aptamers assisted by graphene oxide. Chem Commun (Camb), 2012. 48(15): p. 2071-3.

24. Park, J.W., et al., An ultra-sensitive detection of a whole virus using dual aptamers developed by immobilization-free screening. Biosens Bioelectron, 2014. 51: p. 324-9.

25. Nguyen, V.T., et al., Multiple GO-SELEX for efficient screening of flexible aptamers. Chem Commun (Camb), 2014. 50(72): p. 10513-6.

26. Nutiu, R. and Y. Li, In vitro selection of structure-switching signaling aptamers. Angew Chem Int Ed Engl, 2005. 44(7): p. 1061-5.

27. He, J., et al., Isolation and identification of the DNA aptamer target to acetamiprid. $\mathrm{J}$ Agric Food Chem, 2011. 59(5): p. 1582-6.

28. Wang, L., et al., Selection of DNA aptamers that bind to four organophosphorus pesticides. Biotechnol Lett, 2012. 34(5): p. 869-74.

29. Stoltenburg, R., C. Reinemann, and B. Strehlitz, FluMag-SELEX as an advantageous method for DNA aptamer selection. Anal Bioanal Chem, 2005. 383(1): p. 83-91.

30. Tok, J.B. and N.O. Fischer, Single microbead SELEX for efficient ssDNA aptamer generation against botulinum neurotoxin. Chem Commun (Camb), 2008(16): p. 1883-5.

31. Lauridsen, L.H., et al., Rapid one-step selection method for generating nucleic acid aptamers: development of a DNA aptamer against alpha-bungarotoxin. PLoS One, 2012. 7(7): p. e41702.

32. Oh, S.S., et al., Generation of highly specific aptamers via micromagnetic selection. Anal Chem, 2009. 81(13): p. 5490-5.

33. Lou, X., et al., Micromagnetic selection of aptamers in microfluidic channels. Proc Natl Acad Sci U S A, 2009. 106(9): p. 2989-94.

34. Lai, H.C., et al., Influenza A virus-specific aptamers screened by using an integrated microfluidic system. Lab Chip, 2014. 14(12): p. 2002-13.

35. Cerchia, L., et al., Neutralizing aptamers from whole-cell SELEX inhibit the RET receptor tyrosine kinase. PLoS Biol, 2005. 3(4): p. e123.

36. Daniels, D.A., et al., A tenascin-C aptamer identified by tumor cell SELEX: systematic evolution of ligands by exponential enrichment. Proc Natl Acad Sci U S A, 2003. 100(26): p. 15416-21.

37. Shangguan, D., et al., Aptamers evolved from live cells as effective molecular probes for cancer study. Proc Natl Acad Sci U S A, 2006. 103(32): p. 11838-43.

38. Tang, Z., et al., Selection of aptamers for molecular recognition and characterization of cancer cells. Anal Chem, 2007. 79(13): p. 4900-7.

39. Peng, Z., et al., Rapid fluorescent detection of Escherichia coli K88 based on DNA aptamer library as direct and specific reporter combined with immuno-magnetic separation. J Fluoresc, 2014. 24(4): p. 1159-68. 
40. Kim, Y.S., et al., Isolation and characterization of DNA aptamers against Escherichia coli using a bacterial cell-systematic evolution of ligands by exponential enrichment approach. Anal Biochem, 2013. 436(1): p. 22-8.

41. Savory, N., et al., Selection of DNA aptamers against uropathogenic Escherichia coli NSM59 by quantitative PCR controlled Cell-SELEX. J Microbiol Methods, 2014. 104: p. 94-100.

42. Li, H., et al., Aptamer selection for the detection of Escherichia coli K88. Can J Microbiol, 2011. 57(6): p. 453-9.

43. Bruno, J.G., et al., A novel screening method for competitive FRET-aptamers applied to E. coli assay development. J Fluoresc, 2010. 20(6): p. 1211-23.

44. Bruno, J.G., M.P. Carrillo, and T. Phillips, In vitro antibacterial effects of antilipopolysaccharide DNA aptamer-C1qrs complexes. Folia Microbiol (Praha), 2008. 53(4): p. 295-302.

45. Dwivedi, H.P., R.D. Smiley, and L.A. Jaykus, Selection of DNA aptamers for capture and detection of Salmonella Typhimurium using a whole-cell SELEX approach in conjunction with cell sorting. Appl Microbiol Biotechnol, 2013. 97(8): p. 3677-86.

46. Duan, N., et al., Selection and characterization of aptamers against Salmonella typhimurium using whole-bacterium Systemic Evolution of Ligands by Exponential Enrichment (SELEX). J Agric Food Chem, 2013. 61(13): p. 3229-34.

47. Moon, J., et al., Identification of Salmonella Typhimurium-specific DNA aptamers developed using whole-cell SELEX and FACS analysis. J Microbiol Methods, 2013. 95(2): p. 162-6.

48. Joshi, R., et al., Selection, characterization, and application of DNA aptamers for the capture and detection of Salmonella enterica serovars. Mol Cell Probes, 2009. 23(1): p. 20-8.

49. Park, H.C., et al., Development of ssDNA Aptamers for the Sensitive Detection of Salmonella typhimurium and Salmonella enteritidis. Appl Biochem Biotechnol, 2014. 174(2): p. 793-802.

50. Kolovskaya, O.S., et al., Development of bacteriostatic DNA aptamers for salmonella. J Med Chem, 2013. 56(4): p. 1564-72.

51. Yang, M., et al., Highly specific and cost-efficient detection of Salmonella Paratyphi A combining aptamers with single-walled carbon nanotubes. Sensors (Basel), 2013. 13(5): p. 6865-81.

52. Liu, G., et al., Screening and preliminary application of a DNA aptamer for rapid detection of Salmonella O8. Microchimica Acta, 2012. 178(1-2): p. 237-244.

53. Tang, X., et al., Selection of aptamers against inactive Vibrio alginolyticus and application in a qualitative detection assay. Biotechnol Lett, 2013. 35(6): p. 909-14.

54. Duan, N., et al., Selection and identification of a DNA aptamer targeted to Vibrio parahemolyticus. J Agric Food Chem, 2012. 60(16): p. 4034-8.

55. Suh, S.H., et al., Selection and characterization of DNA aptamers specific for Listeria species. Anal Biochem, 2014. 459: p. 39-45.

56. Suh, S.H. and L.A. Jaykus, Nucleic acid aptamers for capture and detection of Listeria spp. J Biotechnol, 2013. 167(4): p. 454-61.

57. Liu, G.-q., et al., In vitro Selection of DNA Aptamers and Fluorescence-Based Recognition for Rapid Detection Listeria monocytogenes. Journal of Integrative Agriculture, 2014. 13(5): p. 1121-1129. 
58. Duan, N., et al., Selection, identification and application of a DNA aptamer against Listeria monocytogenes. Food Control, 2013. 33(1): p. 239-243.

59. Ohk, S.H., et al., Antibody-aptamer functionalized fibre-optic biosensor for specific detection of Listeria monocytogenes from food. J Appl Microbiol, 2010. 109(3): p. 80817.

60. Duan, N., et al., In vitro selection of a DNA aptamer targeted against Shigella dysenteriae. J Microbiol Methods, 2013. 94(3): p. 170-4.

61. Savory, N., et al., Simultaneous improvement of specificity and affinity of aptamers against Streptococcus mutans by in silico maturation for biosensor development. Biotechnol Bioeng, 2014. 111(3): p. 454-61.

62. Hamula, C.L., X.C. Le, and X.F. Li, DNA aptamers binding to multiple prevalent Mtypes of Streptococcus pyogenes. Anal Chem, 2011. 83(10): p. 3640-7.

63. Chang, Y.C., et al., Rapid single cell detection of Staphylococcus aureus by aptamerconjugated gold nanoparticles. Sci Rep, 2013. 3: p. 1863.

64. Cao, X., et al., Combining use of a panel of ssDNA aptamers in the detection of Staphylococcus aureus. Nucleic Acids Res, 2009. 37(14): p. 4621-8.

65. Savory, N., et al., In silico maturation of binding-specificity of DNA aptamers against Proteus mirabilis. Biotechnol Bioeng, 2013. 110(10): p. 2573-80.

66. Wang, K.Y., et al., Utility of aptamer-fluorescence in situ hybridization for rapid detection of Pseudomonas aeruginosa. Eur J Clin Microbiol Infect Dis, 2011. 30(2): p. 273-8.

67. Chen, F., et al., Aptamer from whole-bacterium SELEX as new therapeutic reagent against virulent Mycobacterium tuberculosis. Biochem Biophys Res Commun, 2007. 357(3): p. 743-8.

68. Vivekananda, J. and J.L. Kiel, Anti-Francisella tularensis DNA aptamers detect tularemia antigen from different subspecies by Aptamer-Linked Immobilized Sorbent Assay. Lab Invest, 2006. 86(6): p. 610-8.

69. Bruno, J.G. and M.P. Carrillo, Development of aptamer beacons for rapid presumptive detection of Bacillus spores. J Fluoresc, 2012. 22(3): p. 915-24.

70. Bruno, J.G. and J.L. Kiel, In vitro selection of DNA aptamers to anthrax spores with electrochemiluminescence detection. Biosens Bioelectron, 1999. 14(5): p. 457-64.

71. Ikanovic, M., et al., Fluorescence assay based on aptamer-quantum dot binding to Bacillus thuringiensis spores. J Fluoresc, 2007. 17(2): p. 193-9.

72. Dwivedi, H.P., R.D. Smiley, and L.A. Jaykus, Selection and characterization of DNA aptamers with binding selectivity to Campylobacter jejuni using whole-cell SELEX. Appl Microbiol Biotechnol, 2010. 87(6): p. 2323-34.

73. Bruno, J.G., et al., Plastic-adherent DNA aptamer-magnetic bead and quantum dot sandwich assay for Campylobacter detection. J Fluoresc, 2009. 19(3): p. 427-35.

74. Stratis-Cullum, D.N., S. McMasters, and P.M. Pellegrino, Evaluation of Relative Aptamer Binding to Campylobacter jejuni Bacteria Using Affinity Probe Capillary Electrophoresis. Analytical Letters, 2009. 42(15): p. 2389-2402.

75. Ferreira, I.M., et al., Selection of Peptidoglycan-Specific Aptamers for Bacterial Cells Identification. Appl Biochem Biotechnol, 2014.

76. Kim, S.E., et al., Harnessing aptamers for electrochemical detection of endotoxin. Anal Biochem, 2012. 424(1): p. 12-20. 
77. Castro-Rosas, J., et al., Presence of faecal coliforms, Escherichia coli and diarrheagenic E. coli pathotypes in ready-to-eat salads, from an area where crops are irrigated with untreated sewage water. Int J Food Microbiol, 2012. 156(2): p. 176-80.

78. Rippey, S.R., Infectious diseases associated with molluscan shellfish consumption. Clin Microbiol Rev, 1994. 7(4): p. 419-25.

79. Bierne, H., et al., Internalins: a complex family of leucine-rich repeat-containing proteins in Listeria monocytogenes. Microbes Infect, 2007. 9(10): p. 1156-66.

80. Kotloff, K.L., et al., Global burden of Shigella infections: implications for vaccine development and implementation of control strategies. Bull World Health Organ, 1999. 77(8): p. 651-66.

81. Friedman, C.R., et al., Risk factors for sporadic Campylobacter infection in the United States: A case-control study in FoodNet sites. Clin Infect Dis, 2004. 38 Suppl 3: p. S28596.

82. Steer, A.C., et al., Invasive group a streptococcal disease: epidemiology, pathogenesis and management. Drugs, 2012. 72(9): p. 1213-27.

83. Lowy, F.D., Staphylococcus aureus infections. N Engl J Med, 1998. 339(8): p. 520-32.

84. Ballok, A.E. and G.A. O'Toole, Pouring salt on a wound: Pseudomonas aeruginosa virulence factors alter $\mathrm{Na}+$ and Cl- flux in the lung. J Bacteriol, 2013. 195(18): p. 4013-9.

85. Gomez, M.I. and A. Prince, Opportunistic infections in lung disease: Pseudomonas infections in cystic fibrosis. Curr Opin Pharmacol, 2007. 7(3): p. 244-51.

86. Maher, D., et al., Treatment of tuberculosis. BMJ, 2003. 327(7419): p. 822-3.

87. Jernigan, J.A., et al., Bioterrorism-related inhalational anthrax: the first 10 cases reported in the United States. Emerg Infect Dis, 2001. 7(6): p. 933-44.

88. Tarnvik, A., Nature of protective immunity to Francisella tularensis. Rev Infect Dis, 1989. 11(3): p. 440-51.

89. Typas, A., et al., From the regulation of peptidoglycan synthesis to bacterial growth and morphology. Nat Rev Microbiol, 2012. 10(2): p. 123-36.

90. Preston, A., et al., The lipooligosaccharides of pathogenic gram-negative bacteria. Crit Rev Microbiol, 1996. 22(3): p. 139-80.

91. Ulevitch, R.J. and P.S. Tobias, Receptor-dependent mechanisms of cell stimulation by bacterial endotoxin. Annu Rev Immunol, 1995. 13: p. 437-57.

92. Escudero-Abarca, B.I., et al., Selection, characterization and application of nucleic Acid aptamers for the capture and detection of human norovirus strains. PLoS One, 2014. 9(9): p. e106805.

93. Giamberardino, A., et al., Ultrasensitive norovirus detection using DNA aptasensor technology. PLoS One, 2013. 8(11): p. e79087.

94. Beier, R., et al., Selection of a DNA aptamer against norovirus capsid protein VP1. FEMS Microbiol Lett, 2014. 351(2): p. 162-9.

95. Wang, R., et al., Selection and characterization of DNA aptamers for use in detection of avian influenza virus H5N1. J Virol Methods, 2013. 189(2): p. 362-9.

96. Shiratori, I., et al., Selection of DNA aptamers that bind to influenza A viruses with high affinity and broad subtype specificity. Biochem Biophys Res Commun, 2014. 443(1): p. 37-41.

97. Chen, F., et al., CS-SELEX generates high-affinity ssDNA aptamers as molecular probes for hepatitis C virus envelope glycoprotein E2. PLoS One, 2009. 4(12): p. e8142. 
98. Gandham, S.H., et al., Thioaptamers Targeting Dengue Virus Type-2 Envelope Protein Domain III. Biochem Biophys Res Commun, 2014.

99. Mosing, R.K., S.D. Mendonsa, and M.T. Bowser, Capillary electrophoresis-SELEX selection of aptamers with affinity for HIV-1 reverse transcriptase. Anal Chem, 2005. 77(19): p. 6107-12.

100. Andreola, M.L., et al., DNA aptamers selected against the HIV-1 RNase H display in vitro antiviral activity. Biochemistry, 2001. 40(34): p. 10087-94.

101. DeStefano, J.J. and G.R. Nair, Novel aptamer inhibitors of human immunodeficiency virus reverse transcriptase. Oligonucleotides, 2008. 18(2): p. 133-44.

102. Schneider, D.J., et al., High-affinity ssDNA inhibitors of the reverse transcriptase of type 1 human immunodeficiency virus. Biochemistry, 1995. 34(29): p. 9599-610.

103. Lai, Y.T. and J.J. DeStefano, DNA aptamers to human immunodeficiency virus reverse transcriptase selected by a primer-free SELEX method: characterization and comparison with other aptamers. Nucleic Acid Ther, 2012. 22(3): p. 162-76.

104. de Soultrait, V.R., et al., DNA aptamers derived from HIV-1 RNase H inhibitors are strong anti-integrase agents. J Mol Biol, 2002. 324(2): p. 195-203.

105. Jing, N. and M.E. Hogan, Structure-activity of tetrad-forming oligonucleotides as a potent anti-HIV therapeutic drug. J Biol Chem, 1998. 273(52): p. 34992-9.

106. Boiziau, C., et al., DNA aptamers selected against the HIV-1 trans-activation-responsive RNA element form RNA-DNA kissing complexes. J Biol Chem, 1999. 274(18): p. 12730-7.

107. Sekkai, D., et al., In vitro selection of DNA aptamers against the HIV-1 TAR RNA hairpin. Antisense Nucleic Acid Drug Dev, 2002. 12(4): p. 265-74.

108. Bellecave, P., et al., Inhibition of hepatitis $C$ virus (HCV) RNA polymerase by DNA aptamers: mechanism of inhibition of in vitro RNA synthesis and effect on HCV-infected cells. Antimicrob Agents Chemother, 2008. 52(6): p. 2097-110.

109. Zhang, Z., et al., An aptamer targets HBV core protein and suppresses HBV replication in HepG2.2.15 cells. Int J Mol Med, 2014. 34(5): p. 1423-9.

110. Shum, K.T. and J.A. Tanner, Differential inhibitory activities and stabilisation of DNA aptamers against the SARS coronavirus helicase. Chembiochem, 2008. 9(18): p. 3037-45.

111. Jeon, S.H., et al., A DNA aptamer prevents influenza infection by blocking the receptor binding region of the viral hemagglutinin. J Biol Chem, 2004. 279(46): p. 48410-9.

112. Cheng, C., et al., Potent inhibition of human influenza H5N1 virus by oligonucleotides derived by SELEX. Biochem Biophys Res Commun, 2008. 366(3): p. 670-4.

113. Wongphatcharachai, M., et al., Neutralizing DNA aptamers against swine influenza H3N2 viruses. J Clin Microbiol, 2013. 51(1): p. 46-54.

114. Choi, S.K., et al., DNA aptamers against the receptor binding region of hemagglutinin prevent avian influenza viral infection. Mol Cells, 2011. 32(6): p. 527-33.

115. Woo, H.M., et al., Single-stranded DNA aptamer that specifically binds to the influenza virus NS1 protein suppresses interferon antagonism. Antiviral Res, 2013. 100(2): p. 33745.

116. Liang, H.R., et al., Isolation of ssDNA aptamers that inhibit rabies virus. Int Immunopharmacol, 2012. 14(3): p. 341-7.

117. Graham, J.C. and H. Zarbl, Use of cell-SELEX to generate DNA aptamers as molecular probes of HPV-associated cervical cancer cells. PLoS One, 2012. 7(4): p. e36103.

118. Nitsche, A., et al., One-step selection of Vaccinia virus-binding DNA aptamers by MonoLEX. BMC Biotechnol, 2007. 7: p. 48. 
119. Koo, H.L., et al., Noroviruses: The leading cause of gastroenteritis worldwide. Discov Med, 2010. 10(50): p. 61-70.

120. Eccles, R., Understanding the symptoms of the common cold and influenza. Lancet Infect Dis, 2005. 5(11): p. 718-25.

121. He, Q., et al., Characterization of monoclonal antibody against SARS coronavirus nucleocapsid antigen and development of an antigen capture ELISA. J Virol Methods, 2005. 127(1): p. 46-53.

122. Rodenhuis-Zybert, I.A., J. Wilschut, and J.M. Smit, Dengue virus life cycle: viral and host factors modulating infectivity. Cell Mol Life Sci, 2010. 67(16): p. 2773-86.

123. Bruno, J.G. and J.L. Kiel, Use of magnetic beads in selection and detection of biotoxin aptamers by electrochemiluminescence and enzymatic methods. Biotechniques, 2002. 32(1): p. 178-80, 182-3.

124. Huang, Y., et al., Selection and characterization of DNA aptamers against Staphylococcus aureus enterotoxin C1. Food Chem, 2015. 166: p. 623-9.

125. Ochsner, U.A., E. Katilius, and N. Janjic, Detection of Clostridium difficile toxins A, B and binary toxin with slow off-rate modified aptamers. Diagn Microbiol Infect Dis, 2013. 76(3): p. 278-85.

126. Ochsner, U.A., et al., Systematic selection of modified aptamer pairs for diagnostic sandwich assays. Biotechniques, 2014. 56(3): p. 125-8, 130, 132-3.

127. Hong, K.L., et al., In vitro selection of single-stranded DNA molecular recognition elements against Clostridium difficile toxin $B$ and sensitive detection in human fecal matter. J Nucleic Acids, 2015. 2015: p. 808495.

128. Tang, X.L., et al., CFP10 and ESAT6 aptamers as effective Mycobacterial antigen diagnostic reagents. J Infect, 2014.

129. Qin, L., et al., The selection and application of ssDNA aptamers against MPT64 protein in Mycobacterium tuberculosis. Clin Chem Lab Med, 2009. 47(4): p. 405-11.

130. Cella, L.N., et al., Nano aptasensor for protective antigen toxin of anthrax. Anal Chem, 2010. 82(5): p. 2042-7.

131. Choi, J.S., et al., Screening and characterization of high-affinity ssDNA aptamers against anthrax protective antigen. J Biomol Screen, 2011. 16(2): p. 266-71.

132. Bruno, J.G., et al., An aptamer beacon responsive to botulinum toxins. Biosens Bioelectron, 2012. 31(1): p. 240-3.

133. Nakamura, C., et al., Usage of a DNA Aptamer as a Ligand Targeting Microcystin. Molecular Crystals and Liquid Crystals Science and Technology, 2001. 371(1): p. 369374.

134. Elshafey, R., M. Siaj, and M. Zourob, In vitro selection, characterization, and biosensing application of high-affinity cylindrospermopsin-targeting aptamers. Anal Chem, 2014. 86(18): p. 9196-203.

135. Handy, S.M., et al., First report of the use of a saxitoxin-protein conjugate to develop a DNA aptamer to a small molecule toxin. Toxicon, 2013. 61: p. 30-7.

136. Cruz-Aguado, J.A. and G. Penner, Determination of ochratoxin a with a DNA aptamer. J Agric Food Chem, 2008. 56(22): p. 10456-61.

137. Cruz-Aguado, J.A. and G. Penner, Fluorescence polarization based displacement assay for the determination of small molecules with aptamers. Anal Chem, 2008. 80(22): p. 8853-5. 
138. Barthelmebs, L., et al., Enzyme-Linked Aptamer Assays (ELAAs), based on a competition format for a rapid and sensitive detection of Ochratoxin A in wine. Food Control, 2011. 22(5): p. 737-743.

139. McKeague, M., et al., Selection and characterization of a novel DNA aptamer for labelfree fluorescence biosensing of ochratoxin A. Toxins (Basel), 2014. 6(8): p. 2435-52.

140. Chen, X., et al., Selection and identification of ssDNA aptamers recognizing zearalenone. Anal Bioanal Chem, 2013. 405(20): p. 6573-81.

141. Chen, X., et al., Screening and Identification of DNA Aptamers against T-2 Toxin Assisted by Graphene Oxide. J Agric Food Chem, 2014.

142. Ma, X., et al., Selection, identification, and application of Aflatoxin B1 aptamer. European Food Research and Technology, 2014. 238(6): p. 919-925.

143. Malhotra, S., et al., Selection of aptamers for aflatoxin M1 and their characterization. J Mol Recognit, 2014. 27(8): p. 493-500.

144. Hong, K.L., et al., In Vitro Selection of Single-Stranded DNA Molecular Recognition Elements against S. aureus Alpha Toxin and Sensitive Detection in Human Serum. Int J Mol Sci, 2015. 16(2): p. 2794-809.

145. Vivekananda, J., C. Salgado, and N.J. Millenbaugh, DNA aptamers as a novel approach to neutralize Staphylococcus aureus alpha-toxin. Biochem Biophys Res Commun, 2014. 444(3): p. 433-8.

146. Scallan, E., et al., Foodborne illness acquired in the United States--major pathogens. Emerg Infect Dis, 2011. 17(1): p. 7-15.

147. Bartlett, J.G. and D.N. Gerding, Clinical recognition and diagnosis of Clostridium difficile infection. Clin Infect Dis, 2008. 46 Suppl 1: p. S12-8.

148. Perelle, S., et al., Production of a complete binary toxin (actin-specific ADPribosyltransferase) by Clostridium difficile CD196. Infect Immun, 1997. 65(4): p. 1402-7.

149. Gandhi, N.R., et al., Multidrug-resistant and extensively drug-resistant tuberculosis: $a$ threat to global control of tuberculosis. Lancet, 2010. 375(9728): p. 1830-43.

150. Steingart, K.R., et al., Fluorescence versus conventional sputum smear microscopy for tuberculosis: a systematic review. Lancet Infect Dis, 2006. 6(9): p. 570-81.

151. Steingart, K.R., et al., Sputum processing methods to improve the sensitivity of smear microscopy for tuberculosis: a systematic review. Lancet Infect Dis, 2006. 6(10): p. 66474.

152. Wilcke, J.T., et al., Clinical evaluation of MPT-64 and MPT-59, two proteins secreted from Mycobacterium tuberculosis, for skin test reagents. Tuber Lung Dis, 1996. 77(3): p. 250-6.

153. Collier, R.J. and J.A. Young, Anthrax toxin. Annu Rev Cell Dev Biol, 2003. 19: p. 45-70.

154. Dhaked, R.K., et al., Botulinum toxin: bioweapon \& magic drug. Indian J Med Res, 2010. 132: p. 489-503.

155. Bourke, A.T. and R.B. Hawes, Freshwater cyanobacteria (blue-green algae) and human health. Med J Aust, 1983. 1(11): p. 491-2.

156. Deeds, J.R., et al., Non-traditional vectors for paralytic shellfish poisoning. Mar Drugs, 2008. 6(2): p. 308-48.

157. Morton, S.L. and D.R. Tindall, Determination of okadaic acid content of dinoflagellate cells: a comparison of the HPLC-fluorescent method and two monoclonal antibody ELISA test kits. Toxicon, 1996. 34(8): p. 947-54. 
158. Petzinger, E. and K. Ziegler, Ochratoxin A from a toxicological perspective. J Vet Pharmacol Ther, 2000. 23(2): p. 91-8.

159. Turner, N.W., S. Subrahmanyam, and S.A. Piletsky, Analytical methods for determination of mycotoxins: a review. Anal Chim Acta, 2009. 632(2): p. 168-80.

160. Wood, G., et al., US Food and Drug Administration's monitoring and surveillance programs for mycotoxins, pesticides and contaminants in food. J Environ Monit, 2001. 3(5): p. 79N-83N.

161. Zinedine, A., et al., Review on the toxicity, occurrence, metabolism, detoxification, regulations and intake of zearalenone: an oestrogenic mycotoxin. Food Chem Toxicol, 2007. 45(1): p. 1-18.

162. Li, Y., et al., T-2 toxin, a trichothecene mycotoxin: review of toxicity, metabolism, and analytical methods. J Agric Food Chem, 2011. 59(8): p. 3441-53.

163. Bennett, J.W. and M. Klich, Mycotoxins. Clin Microbiol Rev, 2003. 16(3): p. 497-516.

164. Tabata, S., et al., Aflatoxin contamination in foods and foodstuffs in Tokyo: 1986-1990. J AOAC Int, 1993. 76(1): p. 32-5.

165. Ha, T.H., et al., A controlled clinical trial of a novel antivenom in patients envenomed by Bungarus multicinctus. J Med Toxicol, 2010. 6(4): p. 393-7.

166. Nirthanan, S. and M.C. Gwee, Three-finger alpha-neurotoxins and the nicotinic acetylcholine receptor, forty years on. J Pharmacol Sci, 2004. 94(1): p. 1-17.

167. Kim, Y.S., et al., Electrochemical detection of 17beta-estradiol using DNA aptamer immobilized gold electrode chip. Biosens Bioelectron, 2007. 22(11): p. 2525-31.

168. Alsager, O.A., et al., Small molecule detection in solution via the size contraction response of aptamer functionalized nanoparticles. Biosens Bioelectron, 2014. 57: p. 2628.

169. Jo, M., et al., Development of single-stranded DNA aptamers for specific Bisphenol a detection. Oligonucleotides, 2011. 21(2): p. 85-91.

170. Xu, S., et al., Selection of DNA aptamers against polychlorinated biphenyls as potential biorecognition elements for environmental analysis. Anal Biochem, 2012. 423(2): p. 195201.

171. Mehta, J., et al., Selection and characterization of PCB-binding DNA aptamers. Anal Chem, 2012. 84(3): p. 1669-76.

172. Sanchez, P.E., DNA Aptamer Development for Detection of Atrazine and Protective Antigen Toxin Using Fluorescence Polarization, in Microbiology. 2012, University of California, Riverside.

173. Schonfelder, G., et al., Parent bisphenol A accumulation in the human maternal-fetalplacental unit. Environ Health Perspect, 2002. 110(11): p. A703-7.

174. Srogi, K., Levels and congener distributions of PCDDs, PCDFs and dioxin-like PCBs in environmental and human samples: a review. Environmental Chemistry Letters, 2008. 6(1): p. 1-28.

175. Graymore, M., F. Stagnitti, and G. Allinson, Impacts of atrazine in aquatic ecosystems. Environ Int, 2001. 26(7-8): p. 483-95.

176. Zhang, C., et al., Organophosphorus pesticides detection using broad-specific singlestranded DNA based fluorescence polarization aptamer assay. Biosens Bioelectron, 2014. 55: p. 216-9. 
177. Wu, W., et al., A simple aptamer biosensor for Salmonellae enteritidis based on fluorescence-switch signaling graphene oxide. RSC Advances, 2014. 4(42): p. 2200922012.

178. Fang, Z., et al., Lateral flow biosensor for DNA extraction-free detection of Salmonella based on aptamer mediated strand displacement amplification. Biosens Bioelectron, 2014. 56: p. 192-7.

179. Yuan, J., et al., A visual detection method for Salmonella Typhimurium based on aptamer recognition and nanogold labeling. Food Control, 2014. 37(0): p. 188-192.

180. Ma, X., et al., An aptamer-based electrochemical biosensor for the detection of Salmonella. J Microbiol Methods, 2014. 98: p. 94-8.

181. Labib, M., et al., Aptamer-based impedimetric sensor for bacterial typing. Anal Chem, 2012. 84(19): p. 8114-7.

182. Wu, W., et al., Gold nanoparticle-based enzyme-linked antibody-aptamer sandwich assay for detection of Salmonella Typhimurium. ACS Appl Mater Interfaces, 2014. 6(19): p. 16974-81.

183. Duan, N., et al., A dual-color flow cytometry protocol for the simultaneous detection of Vibrio parahaemolyticus and Salmonella typhimurium using aptamer conjugated quantum dots as labels. Anal Chim Acta, 2013. 804: p. 151-8.

184. Duan, N., et al., Dual-color upconversion fluorescence and aptamer-functionalized magnetic nanoparticles-based bioassay for the simultaneous detection of Salmonella Typhimurium and Staphylococcus aureus. Anal Chim Acta, 2012. 723: p. 1-6.

185. Zelada-Guillen, G.A., et al., Label-free detection of Staphylococcus aureus in skin using real-time potentiometric biosensors based on carbon nanotubes and aptamers. Biosens Bioelectron, 2012. 31(1): p. 226-32.

186. Hernandez, R., et al., Graphene-based potentiometric biosensor for the immediate detection of living bacteria. Biosens Bioelectron, 2014. 54: p. 553-7.

187. Yuan, J., et al., A sensitive gold nanoparticle-based colorimetric aptasensor for Staphylococcus aureus. Talanta, 2014. 127: p. 163-8.

188. Shi, X., et al., A new aptamer/SWNTs IDE-SPQC sensor for rapid and specific detection of Group A Streptococcus. Sensors and Actuators B: Chemical, 2014. 198(0): p. 431-437.

189. Kim, Y.S., et al., Aptamer cocktails: enhancement of sensing signals compared to single use of aptamers for detection of bacteria. Biosens Bioelectron, 2014. 54: p. 195-8.

190. Wu, W.H., et al., Aptasensors for rapid detection of Escherichia coli O157:H7 and Salmonella typhimurium. Nanoscale Res Lett, 2012. 7(1): p. 658.

191. Luo, C., et al., A Rapid and Sensitive Aptamer-Based Electrochemical Biosensor for Direct Detection of Escherichia Coli O111. Electroanalysis, 2012. 24(5): p. 1186-1191.

192. Zelada-Guillen, G.A., et al., Real-time potentiometric detection of bacteria in complex samples. Anal Chem, 2010. 82(22): p. 9254-60.

193. Kim, L., et al., Potential of fluorophore labeled aptamers for Pseudomonas aeruginosa detection in drinking water. Journal of the Korean Society for Applied Biological Chemistry, 2013. 56(2): p. 165-171.

194. Wu, S., et al., Simultaneous aptasensor for multiplex pathogenic bacteria detection based on multicolor upconversion nanoparticles labels. Anal Chem, 2014. 86(6): p. 3100-7.

195. Zuo, P., et al., A PDMS/paper/glass hybrid microfluidic biochip integrated with aptamerfunctionalized graphene oxide nano-biosensors for one-step multiplexed pathogen detection. Lab Chip, 2013. 13(19): p. 3921-8. 
196. Wang, R. and Y. Li, Hydrogel based QCM aptasensor for detection of avian influenza virus. Biosens Bioelectron, 2013. 42: p. 148-55.

197. Labib, M., et al., Aptamer-based viability impedimetric sensor for viruses. Anal Chem, 2012. 84(4): p. 1813-6.

198. Bai, H., et al., A SPR aptasensor for detection of avian influenza virus H5N1. Sensors (Basel), 2012. 12(9): p. 12506-18.

199. Zhang, H.-J., et al., An aptamer-functionalized gold nanoparticle biosensor for the detection of prion protein. Analytical Methods, 2014. 6(9): p. 2982-2987.

200. Luo, P., et al., Aptamer biosensor for sensitive detection of toxin A of Clostridium difficile using gold nanoparticles synthesized by Bacillus stearothermophilus. Biosens Bioelectron, 2014. 54: p. 217-21.

201. Deng, R., et al., Target-induced aptamer release strategy based on electrochemical detection of staphylococcal enterotoxin B using GNPs-ZrO2-Chits film. Colloids Surf B Biointerfaces, 2014. 120: p. 1-7.

202. Temur, E., et al., Attomole sensitivity of staphylococcal enterotoxin B detection using an aptamer-modified surface-enhanced Raman scattering probe. Anal Chem, 2012. 84(24): p. 10600-6.

203. Queiros, R.B., et al., Evanescent wave DNA-aptamer biosensor based on long period gratings for the specific recognition of E. coli outer membrane proteins. Biosens Bioelectron, 2014. 62: p. 227-33.

204. Queirós, R.B., et al., A label-free DNA aptamer-based impedance biosensor for the detection of E. coli outer membrane proteins. Sensors and Actuators B: Chemical, 2013. 181(0): p. 766-772.

205. Wei, F. and C.M. Ho, Aptamer-based electrochemical biosensor for Botulinum neurotoxin. Anal Bioanal Chem, 2009. 393(8): p. 1943-8.

206. Guo, X., et al., Development of an ultrasensitive aptasensor for the detection of aflatoxin B1. Biosens Bioelectron, 2014. 56: p. 340-4.

207. Shim, W.B., et al., An aptamer-based dipstick assay for the rapid and simple detection of aflatoxin B1. Biosens Bioelectron, 2014. 62: p. 288-94.

208. Nguyen, B.H., et al., Label-free detection of aflatoxin M1 with electrochemical Fe3O4/polyaniline-based aptasensor. Mater Sci Eng C Mater Biol Appl, 2013. 33(4): p. 2229-34.

209. Yang, C., et al., Aptamer-based colorimetric biosensing of Ochratoxin A using unmodified gold nanoparticles indicator. Biosens Bioelectron, 2011. 26(5): p. 2724-7.

210. Jiang, L., et al., Amplified impedimetric aptasensor based on gold nanoparticles covalently bound graphene sheet for the picomolar detection of ochratoxin A. Analytica Chimica Acta, 2014. 806(0): p. 128-135.

211. Lv, Z., et al., A simple and sensitive approach for ochratoxin A detection using a labelfree fluorescent aptasensor. PLoS One, 2014. 9(1): p. e85968.

212. Yang, X., et al., Ultrasensitive electrochemical aptasensor for ochratoxin A based on two-level cascaded signal amplification strategy. Bioelectrochemistry, 2014. 96: p. 7-13.

213. Yuan, Y., et al., Ultrasensitive electrochemiluminescent aptasensor for ochratoxin A detection with the loop-mediated isothermal amplification. Analytica Chimica Acta, 2014. 811(0): p. 70-75.

214. Chen, J., et al., A fluorescent aptasensor based on DNA-scaffolded silver-nanocluster for ochratoxin A detection. Biosens Bioelectron, 2014. 57: p. 226-31. 
215. Park, J.H., et al., A regeneratable, label-free, localized surface plasmon resonance (LSPR) aptasensor for the detection of ochratoxin A. Biosens Bioelectron, 2014. 59: p. 321-7.

216. Ma, W., et al., Femtogram ultrasensitive aptasensor for the detection of Ochratoxin A. Biosens Bioelectron, 2013. 42: p. 545-9.

217. Zhao, Q., X. Geng, and H. Wang, Fluorescent sensing ochratoxin A with single fluorophore-labeled aptamer. Anal Bioanal Chem, 2013. 405(19): p. 6281-6.

218. Hun, X., et al., Signal amplified strategy based on target-induced strand release coupling cleavage of nicking endonuclease for the ultrasensitive detection of ochratoxin A. Biosens Bioelectron, 2013. 39(1): p. 145-51.

219. Hayat, A., et al., Highly sensitive ochratoxin A impedimetric aptasensor based on the immobilization of azido-aptamer onto electrografted binary film via click chemistry. Talanta, 2013. 103: p. 14-9.

220. Hayat, A., et al., Electrochemical grafting of long spacer arms of hexamethyldiamine on a screen printed carbon electrode surface: application in target induced ochratoxin A electrochemical aptasensor. Analyst, 2013. 138(10): p. 2951-7.

221. Hayat, A., S. Andreescu, and J.L. Marty, Design of PEG-aptamer two piece macromolecules as convenient and integrated sensing platform: application to the label free detection of small size molecules. Biosens Bioelectron, 2013. 45: p. 168-73.

222. Barthelmebs, L., et al., Electrochemical DNA aptamer-based biosensor for OTA detection, using superparamagnetic nanoparticles. Sensors and Actuators B: Chemical, 2011. 156(2): p. 932-937.

223. Rhouati, A., et al., Development of an automated flow-based electrochemical aptasensor for on-line detection of Ochratoxin A. Sensors and Actuators B: Chemical, 2013. 176(0): p. 1160-1166.

224. Wang, L., et al., An aptamer-based chromatographic strip assay for sensitive toxin semiquantitative detection. Biosens Bioelectron, 2011. 26(6): p. 3059-62.

225. Wang, L., et al., Fluorescent strip sensor for rapid determination of toxins. Chem Commun (Camb), 2011. 47(5): p. 1574-6.

226. Bonel, L., et al., An electrochemical competitive biosensor for ochratoxin A based on a DNA biotinylated aptamer. Biosens Bioelectron, 2011. 26(7): p. 3254-9.

227. Kuang, H., et al., Fabricated aptamer-based electrochemical "signal-off" sensor of ochratoxin A. Biosens Bioelectron, 2010. 26(2): p. 710-6.

228. Zhang, J., et al., An electrochemical biosensor based on hairpin-DNA aptamer probe and restriction endonuclease for ochratoxin A detection. Electrochemistry Communications, 2012. 25(0): p. 5-7.

229. Wu, J., et al., Ultrasensitive one-step rapid detection of ochratoxin A by the folding-based electrochemical aptasensor. Anal Chim Acta, 2012. 753: p. 27-31.

230. Wu, S., et al., Aptamer-functionalized magnetic nanoparticle-based bioassay for the detection of ochratoxin A using upconversion nanoparticles as labels. Analyst, 2011. 136(11): p. 2306-14.

231. Evtugyn, G., et al., Electrochemical Aptasensor for the Determination of Ochratoxin A at the Au Electrode Modified with Ag Nanoparticles Decorated with Macrocyclic Ligand. Electroanalysis, 2013. 25(8): p. 1847-1854.

232. Xie, S., et al., Development of an electrochemical method for Ochratoxin A detection based on aptamer and loop-mediated isothermal amplification. Biosens Bioelectron, 2014. 55: p. 324-9. 
233. Chen, J., et al., A simple and rapid biosensor for ochratoxin A based on a structureswitching signaling aptamer. Food Control, 2012. 25(2): p. 555-560.

234. Zhang, J., et al., A signal-on fluorescent aptasensor based on Tb3+ and structureswitching aptamer for label-free detection of Ochratoxin A in wheat. Biosens Bioelectron, 2013. 41: p. 704-9.

235. De Girolamo, A., et al., Analytical performances of a DNA-ligand system using timeresolved fluorescence for the determination of ochratoxin A in wheat. Anal Bioanal Chem, 2012. 403(9): p. 2627-34.

236. Castillo, G., et al., Impedimetric DNA Aptasensor for Sensitive Detection of Ochratoxin A in Food. Electroanalysis, 2012. 24(3): p. 512-520.

237. Duan, N., et al., Gold Nanoparticle-Based Fluorescence Resonance Energy Transfer Aptasensor for Ochratoxin A Detection. Analytical Letters, 2012. 45(7): p. 714-723.

238. Tong, P., et al., Simply amplified electrochemical aptasensor of ochratoxin A based on exonuclease-catalyzed target recycling. Biosens Bioelectron, 2011. 29(1): p. 97-101.

239. Tong, P., et al., Double-probe signal enhancing strategy for toxin aptasensing based on rolling circle amplification. Biosensors and Bioelectronics, 2012. 33(1): p. 146-151.

240. Sheng, L., et al., PVP-coated graphene oxide for selective determination of ochratoxin A via quenching fluorescence of free aptamer. Biosens Bioelectron, 2011. 26(8): p. 3494-9.

241. Wang, Z., et al., Electrochemiluminescent aptamer biosensor for the determination of ochratoxin A at a gold-nanoparticles-modified gold electrode using $N$-(aminobutyl)- $N$ ethylisoluminol as a luminescent label. Anal Bioanal Chem, 2010. 398(5): p. 2125-32.

242. Yang, C., et al., Aptamer-DNAzyme hairpins for biosensing of Ochratoxin A. Biosens Bioelectron, 2012. 32(1): p. 208-12.

243. Yang, C., et al., Rapid high-throughput analysis of ochratoxin A by the self-assembly of DNAzyme-aptamer conjugates in wine. Talanta, 2013. 116: p. 520-6.

244. Guo, Z., et al., Single-walled carbon nanotubes based quenching of free FAM-aptamer for selective determination of ochratoxin A. Talanta, 2011. 85(5): p. 2517-21.

245. Prabhakar, N., Z. Matharu, and B.D. Malhotra, Polyaniline Langmuir-Blodgett film based aptasensor for ochratoxin A detection. Biosens Bioelectron, 2011. 26(10): p. 4006-11.

246. Duan, N., S.-J. Wu, and Z.-P. Wang, An Aptamer-based Fluorescence Assay for Ochratoxin A. Chinese Journal of Analytical Chemistry, 2011. 39(3): p. 300-304.

247. Yildirim, N., et al., A portable optic fiber aptasensor for sensitive, specific and rapid detection of bisphenol-A in water samples. Environ Sci Process Impacts, 2014. 16(6): p. 1379-86.

248. Yao, D., et al., Resonance light scattering determination of trace bisphenol A with signal amplification by aptamer-nanogold catalysis. Luminescence, 2014. 29(5): p. 516-21.

249. Zhou, L., et al., An electrochemical aptasensor based on gold nanoparticles dotted graphene modified glassy carbon electrode for label-free detection of bisphenol A in milk samples. Food Chem, 2014. 162: p. 34-40.

250. Ragavan, K.V., L.S. Selvakumar, and M.S. Thakur, Functionalized aptamers as nanobioprobes for ultrasensitive detection of bisphenol-A. Chemical Communications, 2013. 49(53): p. 5960-5962.

251. Mei, Z., et al., Ultrasensitive one-step rapid visual detection of bisphenol A in water samples by label-free aptasensor. Biosensors and Bioelectronics, 2013. 39(1): p. 26-30. 
252. Mei, Z., et al., One-step signal amplified lateral flow strip biosensor for ultrasensitive and on-site detection of bisphenol A (BPA) in aqueous samples. Biosens Bioelectron, 2013. 49: p. 457-61.

253. Yao, D., G. Wen, and Z. Jiang, A highly sensitive and selective resonance Rayleigh scattering method for bisphenol A detection based on the aptamer-nanogold catalysis of the HAuCl4-vitamin C particle reaction. RSC Advances, 2013. 3(32): p. 13353-13356.

254. Lee, J., et al., Aptamer sandwich-based carbon nanotube sensors for single-carbonatomic-resolution detection of non-polar small molecular species. Lab Chip, 2011. 11(1): p. 52-6.

255. Kuang, H., et al., Asymmetric Plasmonic Aptasensor for Sensitive Detection of Bisphenol A. ACS Applied Materials \& Interfaces, 2013. 6(1): p. 364-369.

256. Fan, L., et al., A femtomolar level and highly selective 17beta-estradiol photoelectrochemical aptasensor applied in environmental water samples analysis. Environ Sci Technol, 2014. 48(10): p. 5754-61.

257. Lin, Z., et al., Label-free aptamer-based electrochemical impedance biosensor for 17beta-estradiol. Analyst, 2012. 137(4): p. 819-22.

258. Yildirim, N., et al., Aptamer-based optical biosensor for rapid and sensitive detection of 17beta-estradiol in water samples. Environ Sci Technol, 2012. 46(6): p. 3288-94.

259. Shi, H., et al., Aptamer-based colorimetric sensing of acetamiprid in soil samples: sensitivity, selectivity and mechanism. J Hazard Mater, 2013. 260: p. 754-61.

260. Fan, L., et al., A highly selective electrochemical impedance spectroscopy-based aptasensor for sensitive detection of acetamiprid. Biosens Bioelectron, 2013. 43: p. 12-8.

261. Xiao, Y., et al., Label-free electronic detection of thrombin in blood serum by using an aptamer-based sensor. Angew Chem Int Ed Engl, 2005. 44(34): p. 5456-9.

262. Deng, C., et al., Impedimetric aptasensor with femtomolar sensitivity based on the enlargement of surface-charged gold nanoparticles. Anal Chem, 2009. 81(2): p. 739-45.

263. Tan, L., et al., Affinity analysis of DNA aptamer-peptide interactions using gold nanoparticles. Anal Biochem, 2012. 421(2): p. 725-31.

264. Wang, W., et al., Aptamer biosensor for protein detection using gold nanoparticles. Anal Biochem, 2008. 373(2): p. 213-9.

265. Wang, L., et al., Unmodified gold nanoparticles as a colorimetric probe for potassium DNA aptamers. Chem Commun (Camb), 2006(36): p. 3780-2.

266. Liu, J. and Y. Lu, Fast colorimetric sensing of adenosine and cocaine based on a general sensor design involving aptamers and nanoparticles. Angew Chem Int Ed Engl, 2005. 45(1): p. 90-4.

267. Pavlov, V., et al., Aptamer-functionalized Au nanoparticles for the amplified optical detection of thrombin. J Am Chem Soc, 2004. 126(38): p. 11768-9.

268. Schlensog, M.D., et al., A Love-wave biosensor using nucleic acids as ligands. Sensors and Actuators B: Chemical, 2004. 101(3): p. 308-315.

269. Hwang, K.S., et al., Nanomechanical microcantilever operated in vibration modes with use of RNA aptamer as receptor molecules for label-free detection of HCV helicase. Biosens Bioelectron, 2007. 23(4): p. 459-65.

270. Wang, R.E., et al., Improving the stability of aptamers by chemical modification. Curr Med Chem, 2011. 18(27): p. 4126-38. 


\section{Chapter 2}

\section{Selection of Single-Stranded DNA Molecular Recognition Elements Against Exotoxin A using A Novel Decoy-SELEX Method and Sensitive Detection of Exotoxin A in Human Serum}

This chapter is adapted from the work that is currently under revision for publication in PLoS One.

Citation: Hong KL, Yancey K, Battistella L, Williams RM, Hickey KM, Bostick CD, Gannett PM and Sooter LJ. 2014. "In vitro selection of single-stranded DNA molecular recognition elements against Exotoxin A and sensitive detection in human serum” Under revision, PLoS One 


\subsection{Introduction}

Exotoxin A is a virulence factor secreted by gram negative bacilli bacteria, Pseudomonas aeruginosa [1]. P. aeruginosa has been identified as an opportunistic bacterium that is commonly associated with wound infections, nosocomial lung infections and respiratory diseases in cystic fibrosis patients $[2,3]$. Due to increasing antibiotic resistance, infections caused by $P$. aeruginosa have been associated with decreased in the quality of life, increased mortality in patients and significant cost burden in health care systems [4, 5].

Upon covalent cleavage of the full length protein, the enzymatically active fragment of Exotoxin A enters host cells [6]. It causes ADP-ribosylation of elongation factor 2 and thus inhibits polypeptide assembly to ribosome and protein translation, causing death of host cells [7, 8]. Early studies of purified Exotoxin A report an intravenous lethal dose as low as $3 \mu \mathrm{g} / \mathrm{kg}$ in mice or a $\mathrm{LD}_{50}$ of $\sim 10 \mu \mathrm{g} / \mathrm{kg}$ via intraperitoneal injection $[9,10]$. Because of this highly toxic nature, it is essential to treat $P$. aeruginosa infection as early as possible.

However, current diagnosis of $P$. aeruginosa infection largely relies on traditional methods, such as Gram-stain, bacterial culturing, biochemical methods and immunoassays [11]. Though those methods are sensitive and reliable, they require a significant amount time to confirm infection, prolonging the time between patient clinical presentations and antibiotics treatments. This leads to the initial use of non-specific broad spectrum antibiotics and increases the selection pressure for antibiotic resistant strains of the bacteria [12]. In recent years, molecular diagnostic techniques have been developed to increase the efficiency of diagnosing $P$. aeruginosa infection. A majority of these new techniques use polymerase chain reaction (PCR) to identify genes in P. aeruginosa [13-16]. Although PCR based diagnostic methods are proven to be sensitive, clinical samples presented may have DNA polymerase inhibitor and other 
contaminants that increase chances of false positive, which means that a greater amount of time is required to purify samples [17]. Another major limitation of PCR is that it cannot detect and monitor levels of virulence factors, such as membrane antigens and toxins, for example gene codes for Exotoxin A production is not expressed constitutively, due to different environmental factors [17-19]. Previous studies have demonstrated the clinical role of Exotoxin A in the pathogenesis of P. aeruginosa infections [20, 21]. Patients with higher amount of antibodies against Exotoxin A were correlated to better prognosis [22, 23]. This suggests Exotoxin A is a significant virulence factor of the bacteria, and is also an important $P$. aeruginosa infection biomarker. However, there is currently lack of regulatory approved Exotoxin A detection methods for diagnosis purpose. Therefore, there is an increasing need to develop new methods to rapidly measure Exotoxin A through molecular recognition and detection, and therefore facilitating the diagnosis of $P$. aeruginosa infections.

Systematic Evolution of Ligand by Exponential Enrichment (SELEX) was first described by the Gold laboratory in 1990 [24]. It utilizes an in vitro selection process that identifies Molecular Recognitions Elements (MREs) that have very high affinities and specificities to their target molecules. The selection process of nucleic acid MREs usually begins with a library of $10^{13}$ to $10^{15}$ different single-stranded DNA (ssDNA) or RNA molecules. The library is then subjected to repeating cycles of partitioning and enrichment for molecules that bind to positive target (target of interest) but not to negative targets. Eventually, one or few MREs are identified with high specificities and affinities to the target of interest that will be useful for its detection.

In this study, a novel variation of SELEX termed Decoy-SELEX has been utilized for the identification of a single-stranded DNA MRE that binds to Exotoxin A with high affinity and specificity. The advantage of this variation is an increased emphasis on selecting against negative 
targets. The first negative target, bovine serum albumin (BSA), is selected based on the similarly in structure and amino acid sequence to human serum albumin [25], which is an abundant protein in blood samples. The second negative target, Cholera toxin, served as example of common bacteria virulence factor [26]. The selection scheme is also designed to decrease non-specific binding to streptavidin and biotin, substrates used in target immobilization. Surface plasmon resonance has been used to characterize the affinity and specificity of the selected MRE. In addition, a modified enzyme-linked immunosorbent assay (ELISA) has been developed by using the selected MRE as the toxin capturing element in human serum, and demonstrated the potential use in clinical diagnosis [27-29].

\subsection{Materials and Methods}

\subsubsection{Decoy-SELEX Method for selection of Exotoxin A-specific MREs}

A single-stranded DNA (ssDNA) library consisting of $10^{15}$ molecules was used to begin the selection of Exotoxin A specific MREs. This library, named, RMWN34, consisted of two 23 base of constant regions for primer annealing flanked by a 34 base random region. It was designed by our laboratory and commercially synthesized (Eurofins MWG Operon; Huntsville, AL). A total of 14 rounds of Decoy-SELEX were utilized to enrich Exotoxin A specific MREs (Table 2.1), and eliminate MREs that bind to negative targets (Figure 2.1, 2.2).

Table 2.1: Decoy-SELEX scheme for Exotoxin A MRE selection.

\begin{tabular}{lll}
\hline Round & Positive Selection (+) & Negative Selection (-) \\
\hline $\mathbf{1}$ & Immobilized Target (IT) $46 \mathrm{hrs}, 50 \mu \mathrm{L}$ & Immobilization Substrate (IS) $18 \mathrm{hrs}, 50 \mu \mathrm{L}$ \\
$\mathbf{2}$ & IT $24 \mathrm{hrs}, 50 \mu \mathrm{L}$ & IS $22 \mathrm{hrs}, 50 \mu \mathrm{L}$ \\
$\mathbf{3}$ & IT $18 \mathrm{hrs}, 50 \mu \mathrm{L}$ & - \\
$\mathbf{4}$ & IT $12 \mathrm{hrs}, 50 \mu \mathrm{L}$ & IS $20 \mathrm{hrs}, 50 \mu \mathrm{L}$ \\
$\mathbf{5}$ & IT 8 hrs, $50 \mu \mathrm{L}$ & - \\
\hline
\end{tabular}




\begin{tabular}{lll}
\hline $\mathbf{6}$ & IT $5.5 \mathrm{hrs}, 50 \mu \mathrm{L}$ & $\begin{array}{l}\text { BSA Immobilized Negative Target (INT) 24 } \\
\text { hrs, } 50 \mu \mathrm{L}\end{array}$ \\
$\mathbf{7}$ & IT 1 hrs, $50 \mu \mathrm{L}$ & - \\
$\mathbf{8}$ & IT $1 \mathrm{hrs}, 25 \mu \mathrm{L}$ & Cholera toxin INT $18 \mathrm{hrs}, 50 \mu \mathrm{L}$ \\
$\mathbf{9}$ & IT 1 hrs, $5 \mu \mathrm{L}$ & - \\
$\mathbf{1 0}$ & IT 5 min, $5 \mu \mathrm{L}$ & BSA INT $24 \mathrm{hrs}, 50 \mu \mathrm{L}$ \\
$\mathbf{1 1}$ & IT 5 sec, $5 \mu \mathrm{L}$ & IS $21 \mathrm{hrs}, 10 \mu \mathrm{L}$ \\
$\mathbf{1 2}$ & IT 5 sec, $5 \mu \mathrm{L}$ & - \\
$\mathbf{1 3}$ & IT 5 sec, $5 \mu \mathrm{L}$; Competitive Elution & IT 5 sec, $5 \mu \mathrm{L} ;$ Competitive Elution with 1 \\
& with $2 \mu \mathrm{g}$ free Exotoxin A, 5 sec & mg/mL free BSA, 5 min \\
$\mathbf{1 4}$ & IT 5 sec, Competitive Elution with 1 & - \\
& $\mu$ g free Exotoxin A, 5 sec & \\
\hline
\end{tabular}

In vitro selection performed for identifying Exotoxin A-specific MRE. Immobilized target (IT) is Exotoxin A bound to magnetic beads. Immobilization substrate (IS) is streptavidin-coated magnetic beads blocked with biotin regent. BSA is the abbreviation for bovine serum albumin. Times listed are incubation times in hours (hrs), minutes (min) or seconds (sec).

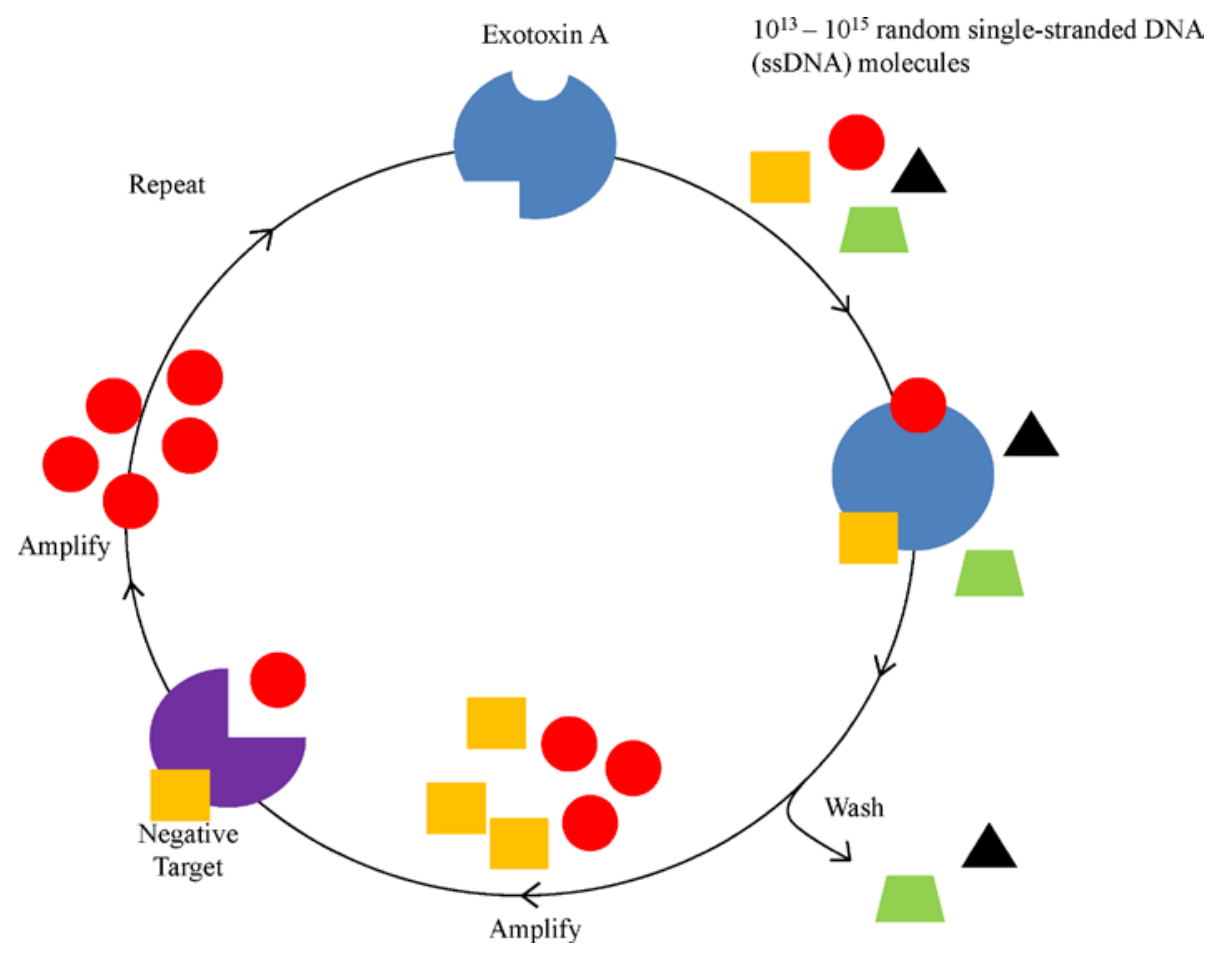


Figure 2.1: Illustration of the Decoy-SELEX process. In vitro selection begins with incubation of target Exotoxin A with a library of $10^{15}$ ssDNA molecules. Binding molecules are amplified and subjected to incubation with multiple negative targets. Molecules that do not bind to negative targets are amplified and carried on to the next round of selection.

(A) Exotoxin A

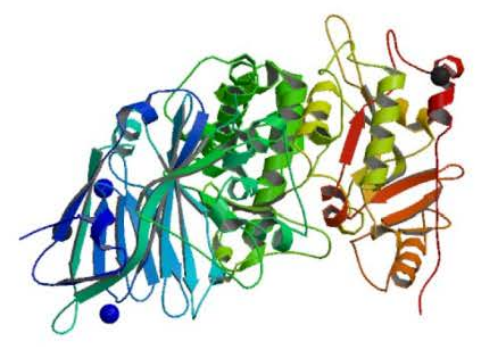

(C) Bovine Serum Albumin

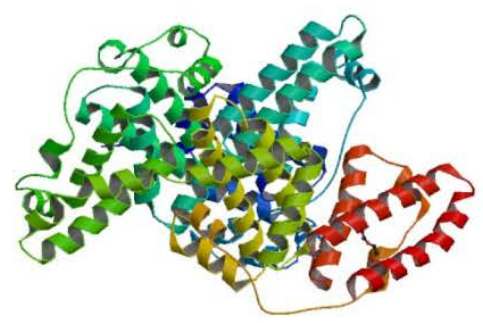

(B) Streptavidin

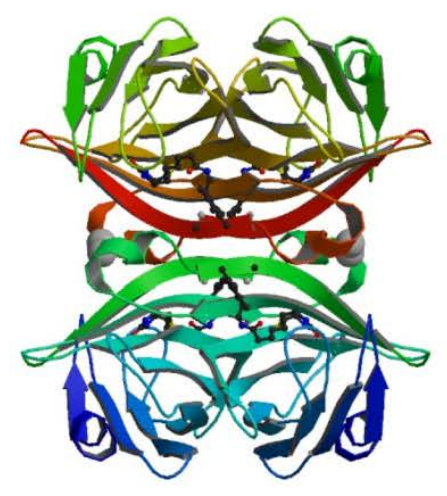

(D) Cholera Toxin

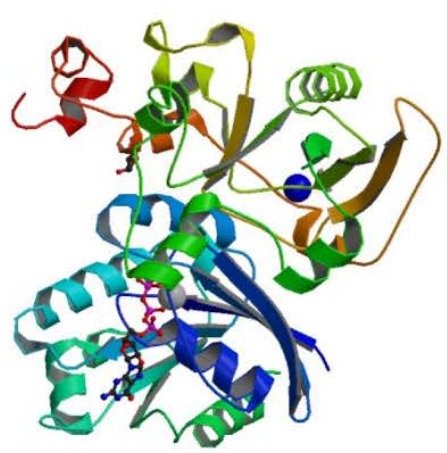

(E) Biotin

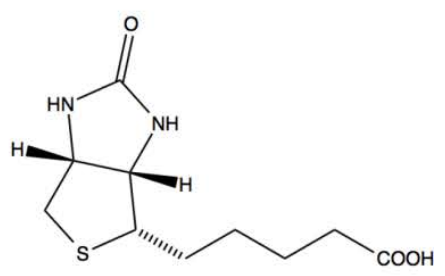

\section{Figure 2.2: Structures of targets used in the Decoy-SELEX and SPR cross binding assays.}

(A) Ribbon structure of the target of interest, Exotoxin A (PDB 1IKQ, 66kDa) [8]. (B) Ribbon structure of streptavidin (PDB 4GJS, 60kDa) used in cross bind assays [30]. (C), (D) Ribbon structures of bovine serum albumin (PDB 4F5S, 66.5kDa) and Cholera toxin (PDB 2A5D, $84 \mathrm{kDa}$ ) used in negative rounds of selection and crossing binding assays [31, 32]. (E) Chemical structure of biotin used in negative rounds of selection and cross binding assays. 
Exotoxin A in lyophilized powder form (List Biological Laboratories; Campbell, CA) was reconstituted in pure water, surface accessible primary amino functional group on Exotoxin A was utilized to covalently biotinylated via Sulfo-NHS-LC-Biotinylation (Pierce; Rockford, IL) according to manufacturer's protocol. Biotinylated Exotoxin A was washed with ZEBA Spin Desalting Column (Pierce, Rockford, IL) to remove excess unreacted biotin. Subsequently, biotinylated Exotoxin A was bound to streptavidin-coated magnetic beads (New England Biolabs, Ipswich, MA) and washed to generate immobilized target (IT) for selections.

In Round $1(+)$ selection, $50 \mu \mathrm{L}$ of IT was incubated with $10^{15}$ copies of ssDNA from the library in a total of $500 \mu \mathrm{L}$ of selection buffer composed of $100 \mathrm{mM}$ sodium chloride, $20 \mathrm{mM}$ Tris-HCl, and $2 \mathrm{mM}$ magnesium chloride ( $1 \times$ selection buffer) at room temperature for 46 hours on rotisserie. After the incubation, the selection mixture was subjected to magnetic separation. Unbound ssDNA was removed and ssDNA bound to IT was washed with $500 \mu \mathrm{L}$ of selection buffer three times and resuspended in $100 \mu \mathrm{L}$ of selection buffer. This solution containing IT functioned as template for PCR amplification using following reaction conditions: enriched ssDNA, 400 nM forward and biotinylated reverse RMW.N34 primers (Eurofins MWG Operon; Huntsville, AL) (forward: 5'-TGTACCGTCTGAGCGATTCGTAC-3', biotinylated reverse: 5'Biotin- GCACTCCTTAACACTGACTGGCT-3'), $250 \mu \mathrm{M}$ deoxynucleotide triphosphates, 1× GoTaq Reaction Buffer (Promega; Madison, WI), 3.5 units Taq, and pure water. Thermal cycling conditions were as follows: first denatured at $95^{\circ} \mathrm{C}$ for 5 minutes, cycling at $95^{\circ} \mathrm{C}$ for 1 minute, $63^{\circ} \mathrm{C}$ for 45 seconds, and $72^{\circ} \mathrm{C}$ for 1 minute; and final extension temperature at $72^{\circ} \mathrm{C}$ for 7 minutes. Small-scale PCR $(1,5,10 \mu \mathrm{L})$ was first performed to determine the optimal cycles for PCR. This was carried in 2 to 3 cycles step-wise manner in order to avoid over amplification of 
the template and unwanted non-specific amplicons. Large-scale PCR (2 to $4 \mathrm{~mL}$ ) was performed after each round of positive and negative selection.

After PCR amplification, PCR product containing dsDNA was purified with the GFX PCR purification kit (GE Healthcare, Piscataway, NJ). Eluted dsDNA containing the biotinylated reverse strand was then incubated with streptavidin agarose resin (Pierce; Rockford, IL) for single strand separations [33]. This mixture was transferred into a flow-through column and washed with 5-volumes of $1 \times$ phosphate buffer solution. Five-volumes of $1 \mathrm{M}$ sodium hydroxide were then added to the column to elute the forward strand of the dsDNA. Subsequently, 0.1volumes of $3 \mathrm{M}$ sodium acetate at $\mathrm{pH}$ 5.2, 2.5-volumes of cold $100 \%$ ethanol and $10 \mu \mathrm{g} / \mathrm{mL}$ of glycogen were added to the eluted ssDNA for ethanol precipitation at $-80^{\circ} \mathrm{C}$. After the solution was frozen, it was then centrifuged at $13,000 \times g$ for 1 hour. Precipitated ssDNA was subsequently washed with $70 \%$ ethanol and centrifuged at $13,000 \times g$ for 15 minutes to remove co-precipitated salt. The ssDNA pellet was dried in a vacuum desiccator and resuspended in 50 $\mu \mathrm{L}$ of selection buffer. A NanoDrop spectrometer (ThermoScientific; Wilmington, DE) was used to confirm the suspension contained at least $10^{13}$ copies of ssDNA before proceeding to next round of selection.

Round 1(-) was performed by incubating enriched ssDNA from the preceding positive round with immobilization substrate in a total volume of $100 \mu \mathrm{L}$ selection buffer at room temperature for 18 hours on rotisserie. Immobilization substrate was prepared by incubating Sulfo-NHS-LC-Biotin (Pierce; Rockford, IL) with Tris-HCl and streptavidin-coated magnetic beads (New England Biolabs, Ipswich, MA). After magnetic separation, unbound ssDNA served as the template for PCR amplification as illustrated above. Positive rounds 1 to 7 and negative rounds 1, 2, 4 and 11 were performed as described with decreasing incubation time in positive 
rounds and increasing incubation time in negative rounds to increase stringency for selection of MREs specific for Exotoxin A.

Starting with round 6(-) selection, the first negative target, bovine serum albumin (BSA) (Rockland Immunochemical; Gilbersville, PA) was introduced to the selection. Immobilized negative targets (INT) were prepared identical to IT, substituting Exotoxin A with bovine serum albumin. INT, $50 \mu \mathrm{L}$, was incubated with enriched ssDNA from the preceding positive selection round in a total of $500 \mu \mathrm{L}$ of selection buffer at room temperature for 24 hours. Unbound ssDNA was removed with magnetic separation and served as template for PCR amplification. Round 10(-) was performed in the same way. In round $8(-)$, the second negative target, Cholera toxin (List Biological Laboratories; Campbell, CA), was introduced. Preparation of Cholera toxin INT was as described above. Selection conditions were similar to round 6(-) with the exception of 18 hours incubation. This was to ensure the selected MRE was specific to Exotoxin A and not BSA or Cholera toxin.

Starting with Round $8(+)$ selection, the volume of IT used was decreased in order to increase the stringency of the selection. Round $13(+)$ and $14(+)$ IT were subjected to competitive elution with free Exotoxin A solution. IT and the enriched ssDNA were initially incubated for 5 seconds in total of $100 \mu \mathrm{L}$ of selection buffer. IT with bound ssDNA was washed with $500 \mu \mathrm{L}$ of selection buffer three times, and then $2 \mu \mathrm{g}$ or $1 \mu \mathrm{g}$ respectively, of Exotoxin $\mathrm{A}$ in $100 \mu \mathrm{L}$ of selection buffer was added to the mixture and then incubated for 5 seconds. The supernatant obtained from magnetic separation was used as template for PCR amplification. Round 13(-) was performed in the same way using a free BSA competitive elution. However, ssDNA bound to IT was separated and served as PCR template. This was to ensure ssDNA only binds to free Exotoxin A and not to free negative targets. 


\subsubsection{Cloning and Sequencing of Exotoxin A-specific MREs}

DNA sequencing was performed following rounds $3(+), 6(-), 9(+), 12(+), 13(+)$, and $14(+)$ to analyze the ssDNA library for consensus binding sequences. The ssDNA library was amplified with non-biotinylated primers. It was then ligated into the pCRII vector (Invitrogen, Carlsbad, CA) and transformed into competent E. coli bacteria according to manufacturer's protocol. Inserted plasmid was subsequently extracted and purified with the AxyPrep Plasmid Prep Kit (Axygen, Union City, CA). The M13R primer, complementary to a region upstream of the PCR insert was sequenced (Eurofins MWG Operon, Huntsville, AL) along with purified plasmid. 30-50 randomly selected sequences for each respective round were subjected to analysis for consensus sequence families.

\subsubsection{Exotoxin A-specific MRE Binding Assays with Surface Plasmon Resonance}

After analyzing round 14 for its DNA sequences, R14.33 was selected for further characterization. The Mfold DNA web server was used to predict the secondary structure with the following conditions: $25^{\circ} \mathrm{C}, 100 \mathrm{mM} \mathrm{Na}^{+}$, and $2 \mathrm{mM} \mathrm{Mg}^{2+}$ [34]. Subsequently, R14.33 was synthesized by Eurofins MWG Operon with a 5' amino-C6 modification for use in surface plasmon resonance (SPR) binding assays.

Glass slides (12 mm x $10 \mathrm{~mm}$ ) were cleaned by sonication in acetone, isopropyl alcohol, and doubly deionized water (5 min, each) and then blown dry with nitrogen. Gold was evaporated on to the slides using Temescal BJD-2000 system (Edwards Vacuum; Phoenix, AZ) with an Inficon XTC/2 deposition controller (Inficon; East Syracuse, NY) (chamber pressures $\leq$ $1.0 \times 10-6$ Torr). Samples were rotated $(3 \mathrm{rpm})$ and monitored during deposition for metal thickness (6 MHz quartz piezoelectric crystals, gold-coated) (Kurt J. Lesker Co., Clairton, PA). 
Rates of $0.3-0.5 \AA / \mathrm{s}$ were maintained during the deposition of a titanium adhesion layer $(2 \mathrm{~nm})$ and a gold layer $(50 \mathrm{~nm})$. After that, samples were cooled to room temperature before being removed from the chamber.

The gold slide was then cleaned in 100\% ethanol under sonication for 5 minutes, then placed in a solution containing $10 \mathrm{mM}$ 11-mercaptoundecanoic acid (11-MUA) (Sigma; St. Louis, MO) and $10 \mathrm{mM}$ triethylene glycol mono-11-mercaptoundecylether (PEG3) (Sigma; St. Louis, MO) in a 1 to 5 ratio for 24 hours under argon. After the formation of the self-assembled monolayer (SAM), the gold slide was rinsed with $100 \%$ ethanol, pure water, and blown dry with a slow stream of nitrogen. The prepared gold slide was inserted into the carrying cartridge and docked into a Biacore X100 (GE Healthcare; Piscataway, NJ). The running buffer for immobilization was composed of $100 \mathrm{mM}$ sodium chloride, $20 \mathrm{mM}$ potassium phosphate, and 2 mM magnesium chloride, pH 7.56 (1× immobilization buffer). Next, $100 \mathrm{mM} \mathrm{N-}$ hydroxysulfonyl succinimide (sulfo-NHS) (Pierce; Rockford, IL) and $400 \mathrm{mM}$ 1-ethyl-3-(3dimethylaminopropyl) (EDC) (Pierce; Rockford, IL) was mixed (1:1) and injected into flow cell 1 and 2 at a flow rate of $5 \mu \mathrm{L} / \mathrm{min}$ for ten minutes for the activation of the carboxyl group of 11MUA. Then, $300 \mu \mathrm{L}$ of $1 \mu \mathrm{M}$ 5'amino modified ssDNA in immobolization buffer (after denaturing at $95^{\circ} \mathrm{C}$ for $5 \mathrm{~min}$ and cooling to room temperature) was injected into flow cell 2 at a rate of $5 \mu \mathrm{L} / \mathrm{min}$. At the end of the DNA injection, unreacted carboxyl groups were inactivated by injection of selection buffer twice for a total of twenty minutes, followed by a regeneration cycle with $45 \mathrm{mM}$ glycine, $100 \mathrm{mM}$ sodium hydroxide in 5\% ethanol (regeneration buffer) for 30 seconds $[35,36]$.

After immobilization, selection buffer was then used as the running buffer for binding assays. The binding affinity of R14.33 was determined by injecting concentrations of $0,0.5,1$, 
1.2, 1.4 and $2 \mu \mathrm{M}$ of Exotoxin A in flow cells 1 and 2 at a flow rate of $5 \mu \mathrm{L} / \mathrm{min}$ at room temperature. Each cycle comprised a 180 seconds wait period, 180 seconds contact period, 180 seconds wait period and 30 seconds regeneration period using regeneration buffer. Assays were performed in duplicate. Kinetic data was analyzed using the Scrubber-2 software (BioLogic Software; Campbell, Australia) to determine the equilibrium dissociation constant $\left(\mathrm{K}_{\mathrm{d}}\right)$, assuming a one-to-one kinetics model.

To determine the cross binding activity of R14.33 to negative targets, blank selection buffer and $5 \mu \mathrm{M}$ each of Exotoxin A, BSA, biotin (Sigma; St. Louis, MO), Cholera toxin, and streptavidin (Amresco; Solon, OH) were injected into both flow cells with the same conditions as described above. Each molecule was tested in triplicate. All data was averaged and standard deviations were calculated as previously described [35]. One-way ANOVA and Bonferroni posthoc test were performed to determine statistical differences in the means for analytes.

\subsubsection{Exotoxin A-specific MRE modified ELISA assays}

A sandwich ELISA assay modified with ssDNA MRE was developed. R14.33 was commercially synthesized with 5' biotinlylation for the use as the antigen capturing element (Eurofins MWG Operon; Huntsville, AL). Streptavidin coated 96-well plate (Pierce; Rockford, IL) was washed three times for 5 minutes, with $200 \mu \mathrm{L}$ of wash buffer ( $1 \times$ selection buffer, $0.1 \%$ BSA, $0.05 \%$ Tween-20 detergent). Subsequently, $100 \mu \mathrm{L}$ of $40 \mathrm{nM}$ 5' biotinylated ssDNA in selection buffer (after denaturing at $95^{\circ} \mathrm{C}$ for 5 min and cooling to room temperature) was added to sample wells and incubated for 2 hours with shaking at room temperature. Each well was washed three times with wash buffer to remove non-immobilized ssDNA. A negative control for each replicate consisted of a blank well without immobilized ssDNA. Then, $100 \mu \mathrm{L}$ of each $1 \times$ phosphate buffer solution, selection buffer, $100 \mathrm{nM}$ of Exotoxin A in selection buffer, human 
serum (Sigma; St. Louis, MO), or $100 \mathrm{nM}$ of Exotoxin A in human serum were added to individual sample wells. The plate was incubated for 1 hour with shaking at room temperature.

Following sample incubation, each well was washed three times with wash buffer to remove unbound Exotoxin A. Next, $100 \mu \mathrm{L}$ of 1:100 dilution of primary goat anti-Exotoxin A antibody (List Biological Laboratories; Campbell, CA) in wash buffer was added to each well and followed by 30 minutes of incubation with shaking at room temperature. Following primary antibody incubation, each well was washed three times. Subsequently, $100 \mu \mathrm{L}$ of 1:500 dilution of secondary rabbit anti-goat antibody conjugated to horseradish peroxidase (Pierce; Rockford, IL) in wash buffer was added to each well and incubated for 30 minutes at room temperature with shaking. Lastly, each well was washed five times to remove non-specifically bound antibodies. Controls with no antibodies added and with only primary antibodies added were also performed. Assays were performed in quadruplicate.

ABTS substrate (Pierce; Rockford, IL) was added to each well according to the manufacturer's instruction. After ABTS was added, absorbance was measured in a Synergy 2 microplate reader with OD reading at $410 \mathrm{~nm}$ and $650 \mathrm{~nm}$ using Gen5 1.06 software (Biotek US; Winooski, VT) in two-minute increments. All data was averaged and standard deviations were calculated. For each Exotoxin A containing sample, a two tailed t-test was performed to determine statistical differences respectively to their blank controls (selection buffer or human serum).

\subsection{Results and discussions}

\subsubsection{Selection of Exotoxin A-specific MREs}

Fourteen rounds of Decoy-SELEX were performed to identify ssDNA MREs specific to Exotoxin A. The selection scheme was aimed to direct the ssDNA MREs to bind to free 
Exotoxin A in solution and reduce enrichment of non-specific binding to immobilization substrates, BSA, and Cholera toxin. Initially, 30-50 randomly selected sequences were analyzed for consensus sequence family after every 3 rounds of selection (rounds 3, 6, 9, 12). Toward the end of the selection, in order to monitor the enrichment of family sequences more frequently, 3050 random sequences from both round 13 and 14 were analyzed. In the round 14 ssDNA library, there was a noticeable and significant convergence of sequence families in one sequence, R14.33 (Table 2.2), which was subsequently chosen for further characterization. The sequence had a Gibbs energy value of $-9.93 \mathrm{kcal} / \mathrm{mol}$ which indicated it would assume a highly stable structure according to Mfold prediction (Figure 2.3).

Table 2.2: Sequence families after Round 14 Decoy-SELEX.

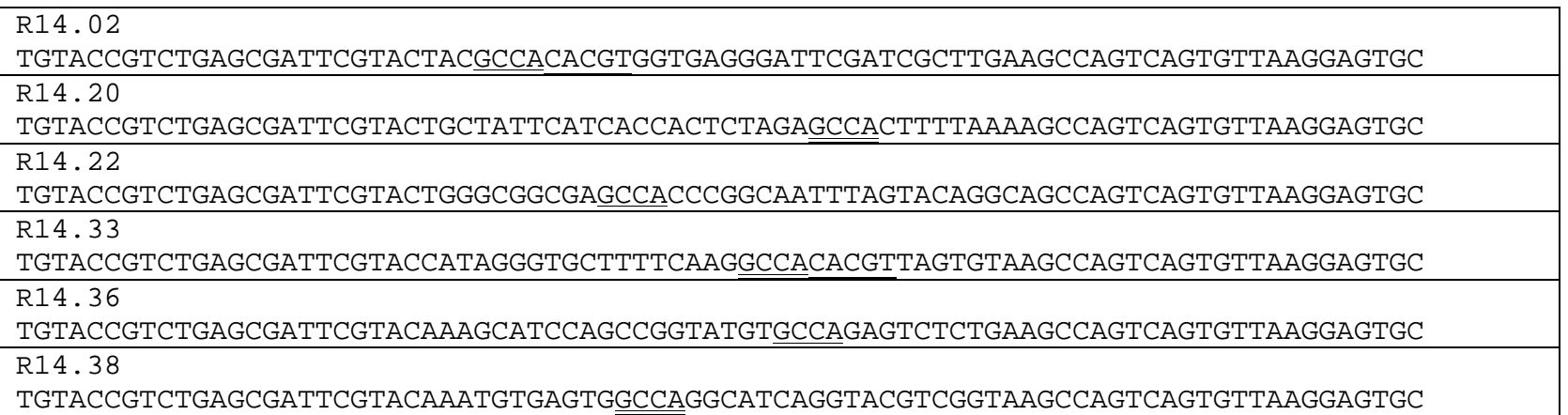

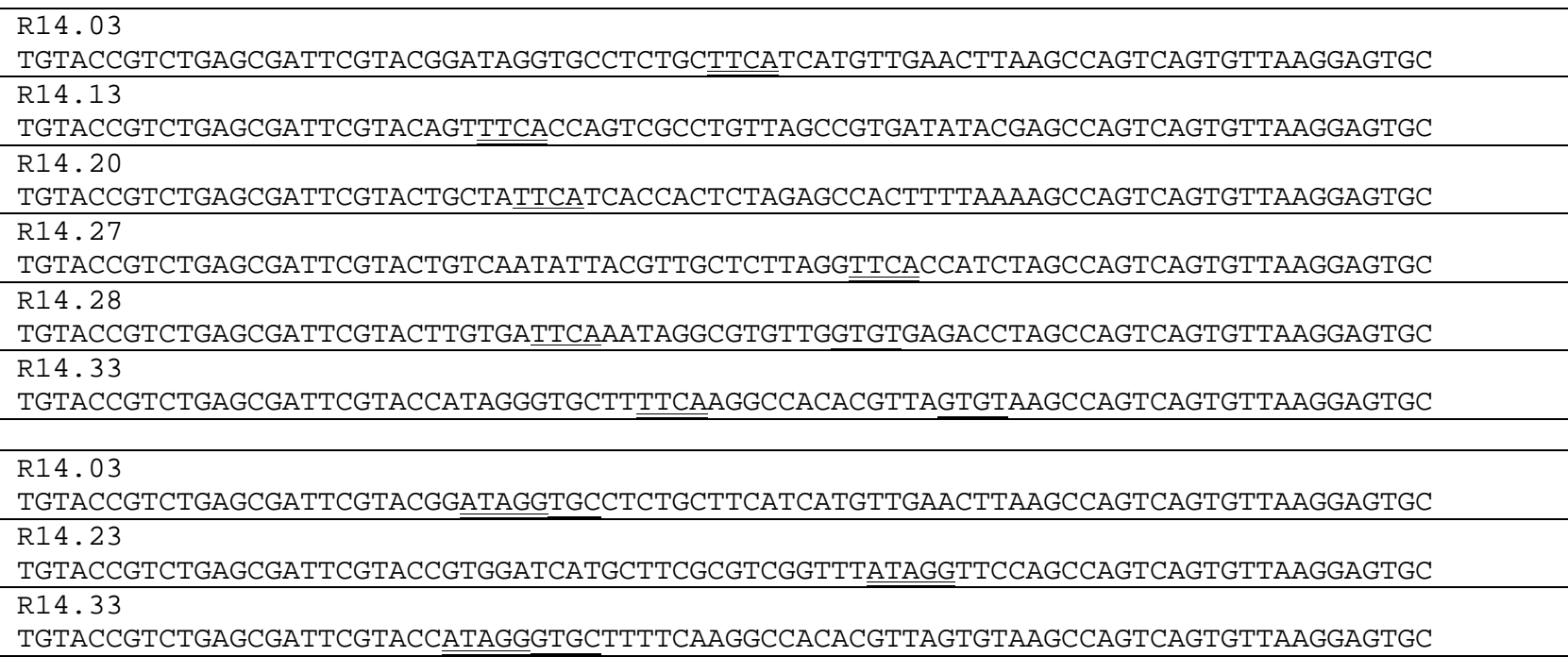


R14.39

TGTACCGTCTGAGCGATTCGTACAGAAGAGCATCGGTAACTTCCATAGGAGATGGGGAGCCAGTCAGTGTTAAGGAGTGC

\begin{tabular}{|c|}
\hline $\begin{array}{l}\text { R14. } \odot 2 \text { 2 } \\
\text { TGTACCGTCTGAGCGATTCGTACTACGCCACACGTGGTGAGGGATTCGATCGCTTGAAGCCAGTCAGTGTTAAGGAGTGC }\end{array}$ \\
\hline $\begin{array}{l}\text { R14. } 06 \\
\text { TGTACCGTCTGAGCGATTCGTACCATCCGAGGGTATTGTATGCGTATATCCTAGTCGAGCCAGTCAGTGTTAAGGAGTGC }\end{array}$ \\
\hline $\begin{array}{l}\text { R14.10 } \\
\text { TGTACCGTCTGAGCGATTCGTACCAAGTTCCTCATGGAGGGTGCTCAGAGCTTAGACAGCCAGTCAGTGTTAAGGAGTAA }\end{array}$ \\
\hline $\begin{array}{l}\text { R14. } 33 \\
\text { TGTACCGTCTGAGCGATTCGTACCATAGGGTGCTTTTCAAGGCCACACGTTAGTGTAAGCCAGTCAGTGTTAAGGAGTGC }\end{array}$ \\
\hline $\begin{array}{l}\text { R14. } 34 \\
\text { TGTACCGTCTGAGCGATTCGTACAGGGGGATTCCTAGGGCCCGGCCCAACGCTGTTTAGCCAGTCAGTGTTAAGGAGTGC }\end{array}$ \\
\hline $\begin{array}{l}\text { R14. } 42 \\
\text { TGTACCGTCTGAGCGATTCGTACCAAGACCCTTGAATCACGGGTAGGGTCTCGTAACAGCCAGTCAGTGTTAAGGAGTGC }\end{array}$ \\
\hline
\end{tabular}

Representative sequence families following Round 14 of Decoy-SELEX. Families are grouped by boxes with common sequences $\underline{\underline{\text { double-underlined }} \text { and sub-families underlined. }}$

(A)

(B)

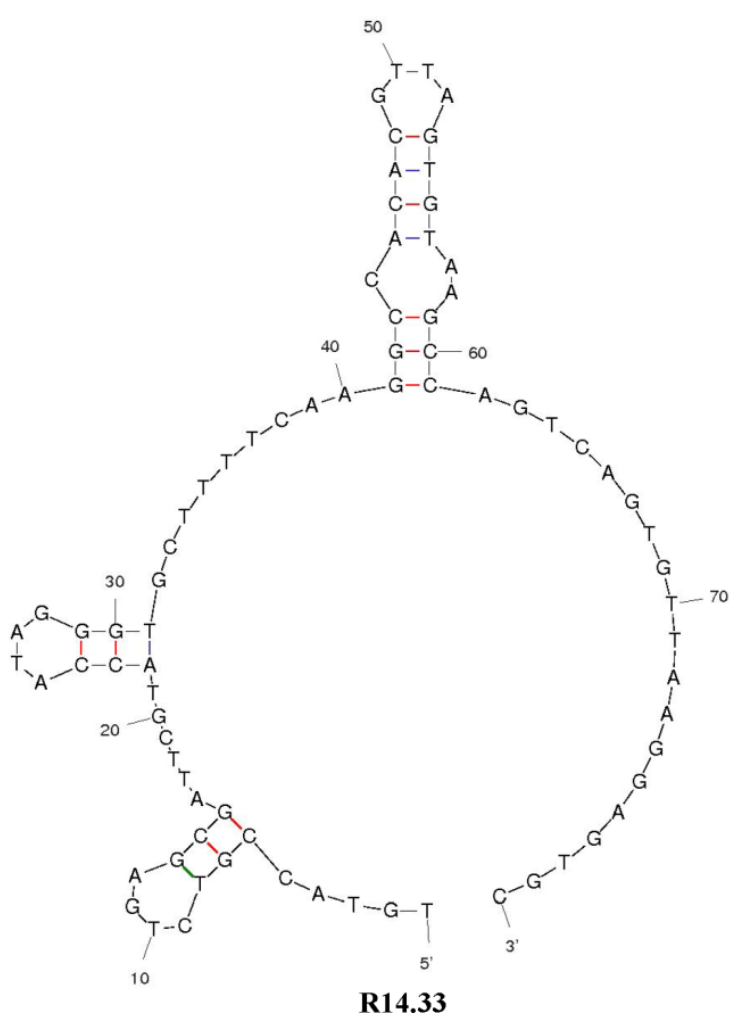


Figure 2.3: Secondary structure and sequence of R14.33 ssDNA MRE. (A) ssDNA sequence of Exotoxin A MRE R14.33. Gray letters indicates constant regions of the MRE. (B) Mfold prediction of R14.33 secondary structure [34].

\subsubsection{Affinity and Specificity of Exotoxin A-specific MRE}

Affinity of the selected MRE was determined by SPR binding assays. Assays were performed with Exotoxin A concentration from high $\mathrm{nM}$ to low $\mu \mathrm{M}$ range with at least 2 duplicate concentrations. The equilibrium dissociation constant $\left(\mathrm{K}_{\mathrm{d}}\right)$ was between 4.2 to $4.5 \mu \mathrm{M}$ (Figure 2.4). In recent years, there have been a number of MREs have been selected against protein targets which utilized SPR for characterization of binding affinity. Reported equilibrium dissociation constants in these studies ranged from low-nanomolar to high-nanomolar range [3741]. It is to be noted that these studies relied on different immobilization methods than what was used here, including streptavidin/ biotin linkage and thiolated DNA attachment [38-41]. Also, several studies utilized a sandwich detection method to amplify signals and thus enhance limit of detections [39, 42, 43]. 
(A)

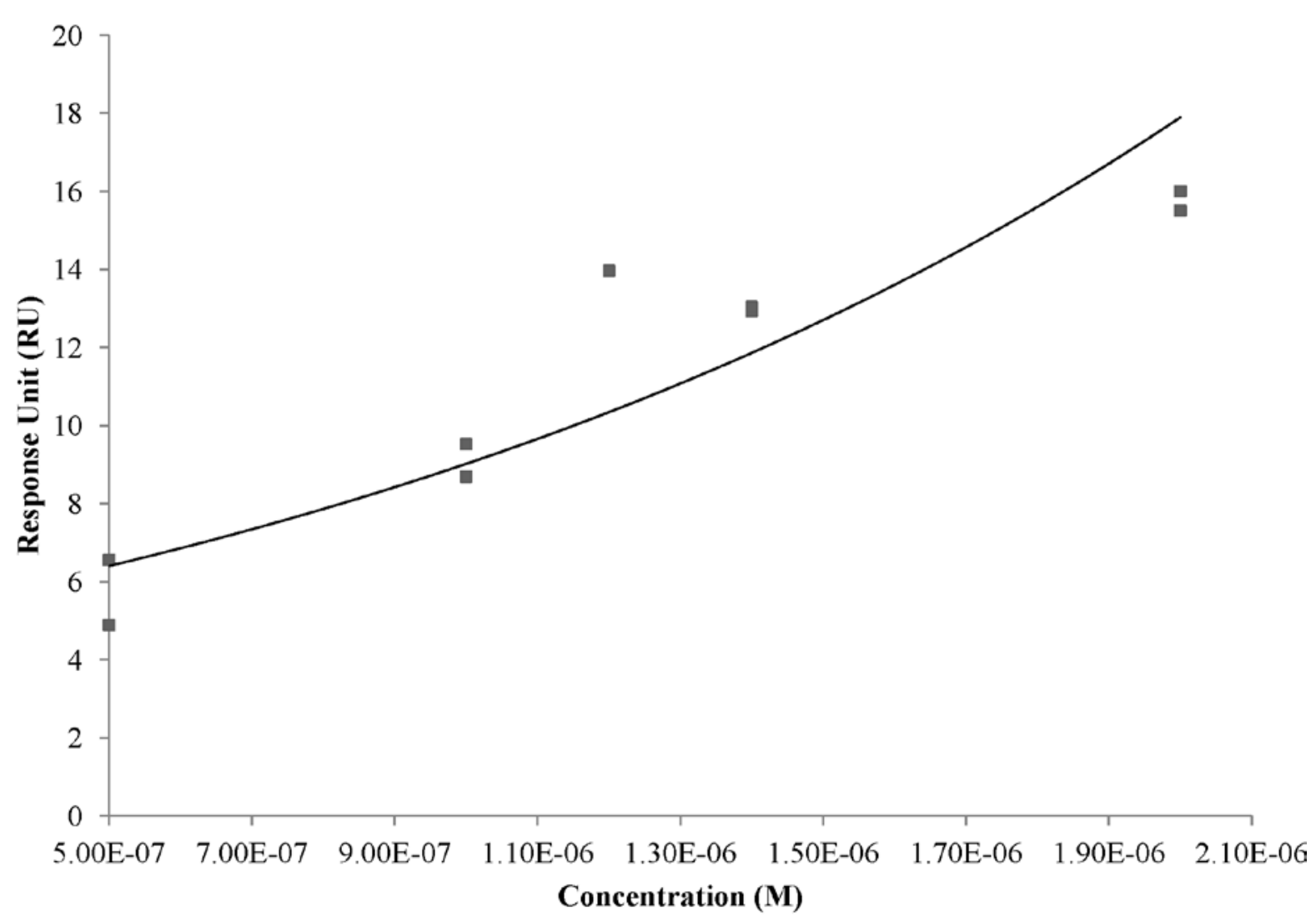

(B)

\begin{tabular}{|c|c|c|}
\hline Plot & $K_{d}$ & Std Error \\
\hline 1 & $4.2 \mathrm{uM}$ & $3 \mathrm{uM}$ \\
\hline 2 & $4.5 \mathrm{uM}$ & $3 \mathrm{uM}$ \\
\hline
\end{tabular}

Figure 2.4: SPR binding kinetics assays of R14.33 ssDNA MRE. Data represent $K_{d}$ of R14.33 from two binding assays evaluated via Scrubber 2 software (Software; Campbell, Australia). (A) Representative binding response curve of R14.33. (B) Equilibrium dissociation constants and standard error of two binding assays. The average $\mathrm{K}_{\mathrm{d}}$ is $4.35 \pm 2.12 \mu \mathrm{M}$.

SPR cross binding assays were performed to test the specificity of the selected Exotoxin A MRE. Concentrations of all cross binding analytes were higher than those used in affinity assays to ensure R14.33 has no non-specific binding to negative targets. The method of 
presentation of the current data as relative response unit of R14.33 to all analytes has been previously described [35, 43]. Binding responses showed a much higher affinity of R14.33 to Exotoxin $\mathrm{A}$ in solution than to all negative targets (one-way ANOVA: $\mathrm{F}_{2,12}=573.4, p<0.001$ ) (Figure 2.5), as well as to streptavidin, a significant component of the immobilization substrate. This is noteworthy as streptavidin was present in all of the selection rounds. It is clear that competitive elutions performed in the last two positive rounds gave the ssDNA library selectivity for free Exotoxin $\mathrm{A}$ in solution over immobilized target and other negative targets, thus validating the Decoy-SELEX method.

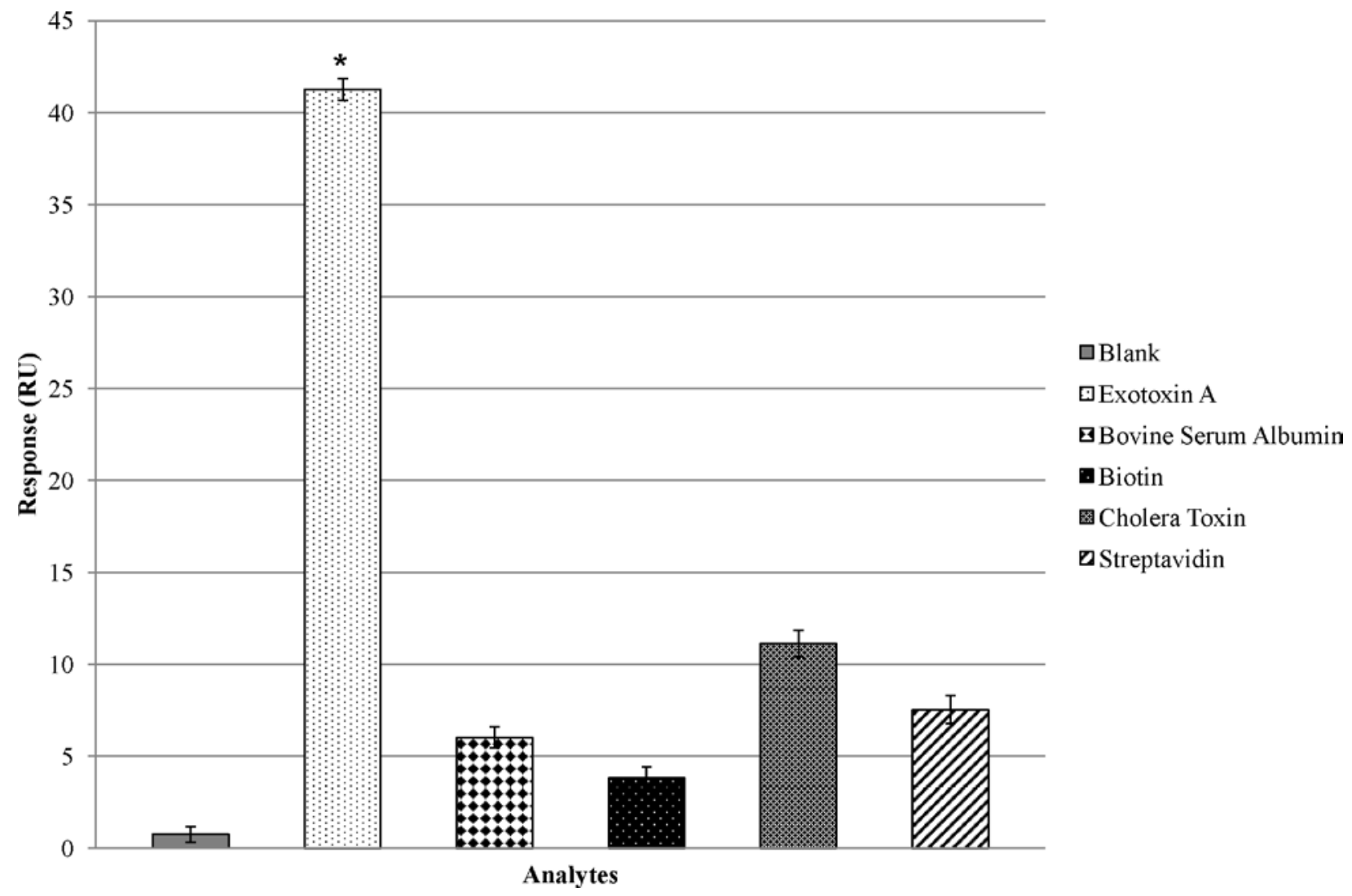

Figure 2.5: SPR cross binding assays of R14.33. Data represent specificity of R14.33 Exotoxin A MRE. Error bars represents standard deviations of three runs. Statistical significance levels of 
$p<0.001$ are designated by '*'. The observed significance levels are adjusted by Bonferroni post-hoc procedure. Exotoxin A has a significantly higher response when compare to blank control and all other analytes, indicating low cross-binding activities of R14.33. Blank represents $1 \times$ selection buffer. Concentrations of all analytes are at $5 \mu \mathrm{M}$.

The determined equilibrium binding constant of the selected Exotoxin A MRE is higher than other studies utilizing SPR binding assays. This difference is likely due to different methods of immobilizing the ssDNA MRE as noted above and thus leads to a lower level of immobilization and detection responses. The current study utilizes direct covalent conjugation of 5' amino modified ssDNA to the SAM on gold surface [36]. One of the major challenges of this method is the electrostatic repulsion between negatively charged DNA and deprotonated carboxyl groups on the SAM surface during immobilization under neutral to basic running buffer. However, covalently attached DNA provides a more stable immobilization as compared to streptavidin/biotin and thiolated DNA attachment under a wide range of storage conditions. This is a potential advantage in the real application of a ssDNA MREs based biosensor, as the longevity of the biological probe is a huge determining factor of its application value [44]. It is also important to note that previous study demonstrated a 100 -fold higher $K_{d}$ between SPR binding measurements and binding assays relying on free ssDNA in solution [45]. This is likely due to the difference in the availability of binding pockets on MREs that are immobilized on solid platform as compared to being in solution. The SPR setup in this study is also very similar to the potential design of a final sensor. Therefore, this is a very realistic assay and is translational as a sensor. 


\subsubsection{Diagnostic application of Exotoxin A-specific MRE}

The Exotoxin A specific MRE demonstrated high specificity, and minimal cross binding activity to BSA. It is reasonable to believe this low binding property may be extrapolated to human serum albumin [38]. This allowed the investigation of using the selected MRE as a potential diagnostic tool. A sandwich ELISA assay modified with the ssDNA MRE as the toxin capturing element was developed. Reproducible and statistically significant detection of Exotoxin A at $100 \mathrm{nM}$ in spiked human serum samples were achieved compare to negative controls in six independent assays $(p<0.05$ to $p<0.001)$ (Figure 2.6).

(A)

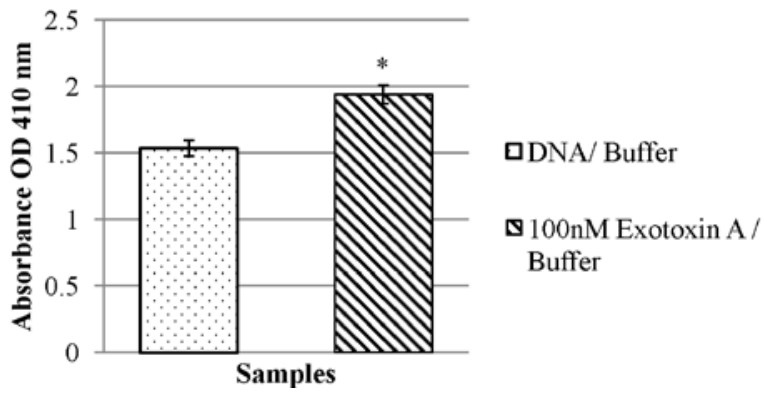

(B)

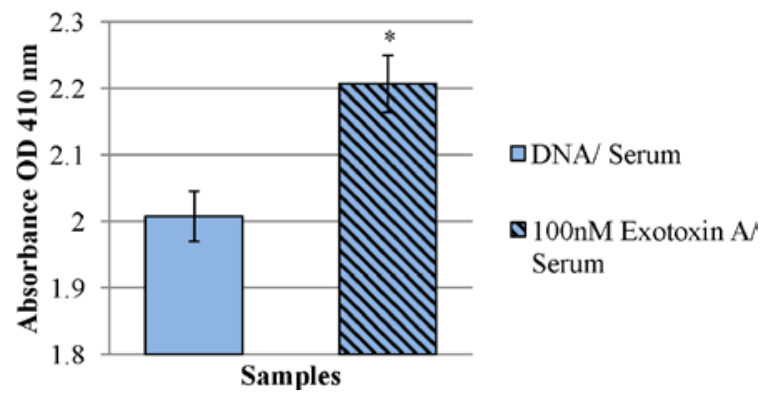

Figure 2.6: Modified ELISA assays of Exotoxin A. Data represent one modified sandwich ELISA with absorbance measured at OD $410 \mathrm{~nm}$. Absorbance levels presented are subtracted from background levels of blank well without immobilized DNA. Error bars represents standard deviations of 4 sample replicates in one independent assay. (A) Statistical significance levels with respect to buffer background of $p<0.001$ are designated by '*'. (B) Statistical significant levels with respect to human serum background of $p<0.001$ are designated by '*’. Buffer: $1 \times$ selection buffer; serum: human serum. 
It has been reported that ssDNA MRE generally has a half-life of 1 hour in human serum due the presence of exonuclease [46]. Therefore, toxin incubation time ranged from five minutes to one hour was tested during assay development. While a portion of the immobilized MRE is likely to be degraded in serum condition, the one-hour toxin incubation period yielded the most consistent result and therefore it was utilized in all experimental assays.

Previous study has attempted to incorporate ssDNA MRE into a system for target detection in buffer diluted human serum [47]. Similar ssDNA MRE modified ELISA assay for the detection of bacteria toxins have been previously described [48, 49]. However, clinically relevant samples were not tested in both studies. It is known that the binding activities of nucleic acid MREs are highly dependent on their three dimensional structures, and are influenced by factors such as temperature, $\mathrm{pH}$ and ionic strength of the binding environment [50]. This leads to challenges in applying nucleic acid MREs in targets' native complex environments, such as human serum [51]. This study demonstrated an improvement to these previous reported studies by showing the robustness of the selected Exotoxin A specific MRE in undiluted serum without any base modifications, and it was able to retain a level of binding activity in an environment that was very much different than the selection condition.

Currently, there are limited studies in quantifying the amount of Exotoxin A in vivo. Previous studies showed large differences in the levels of Exotoxin A detected in murine serum (averaged $116.0 \mathrm{ng} / \mathrm{mL}$ ) and in culture media (averaged $1.4 \mu \mathrm{g} / \mathrm{mL}$ ) [52, 53]. One study showed a significant differences in Exotoxin A detected in different patient sputum samples $(0.3 \mathrm{ng} / \mathrm{mL}$ to $126 \mathrm{ng} / \mathrm{mL}$ ), and as high as $29.3 \mu \mathrm{g} / \mathrm{mL}$ of Exotoxin A was detected in the culture supernatant of sputum isolated P. aeruginosa [54]. It has also been reported that blood isolated P. aeruginosa produced the highest amount of Exotoxin A in culture conditions (approximately $0.3 \mu \mathrm{g} / \mathrm{mL}$ ) 
[55]. Overall, these results suggest that in vivo levels of Exotoxin A vary significantly and are not well quantified in human patients.

Historically, an ADP-ribosylation assay has been utilized to quantify the amount of Exotoxin A in research studies [20,55-58]. This assay requires the use of radioactive NAD and intensive experimental preparations, and therefore it may not be practical for diagnostic use. Although a traditional antibody-based sandwich ELISA assay (MyBioSource; San Diego, CA) is commercially available with a reported detection range between $0.156 \mathrm{ng} / \mathrm{mL}$ and $10 \mathrm{ng} / \mathrm{mL}$, it was designed for research purpose only. Also, given the likelihood of wide ranges of Exotoxin A levels in vivo. The relatively narrow detection range of the commercial ELISA kit may limit its usage in clinical samples. It is to be noted that in our ssDNA MRE modified ELISA assays, 100 $\mathrm{nM}$ or $6.6 \mu \mathrm{g} / \mathrm{mL}$ of Exotoxin A in human serum was detected. While this is highly reproducible, the differences compare to negative controls are small enough to be near the assay's detection limit. Based upon the available clinical data on Exotoxin A level in patients, it is difficult to completely rule out the clinical usage of the current ssDNA MRE modified ELISA assay. In order to transition the current assay into a final product for clinical use, it will need more modification, optimization and possibly with industrial partnership. Nevertheless, ssDNA MRE modified assay does offer several advantages when compared to ELISA assays that are based solely on antibodies, such as thermostability, and regeneration of assay by a basic buffer wash [59].

Overall, this study has identified a ssDNA MRE with high affinity and specificity for Exotoxin A of $P$. aeruginosa. To our knowledge, this is the first ssDNA MRE targeting Exotoxin A. The successful use of SPR for MRE characterizations showed the potential of it being incorporated into a SPR-based biosensor for real time, label-free detection of Exotoxin A in 
biological matrices [38, 39]. In addition, the ssDNA MRE modified ELISA assay offers a potential new way to facilitate the diagnosis of $P$. aeruginosa infection by rapidly quantifying the presence of one of the most significant virulence factors in approximately 2 hours from toxin incubation to detection, and with minimal sample manipulations. This method may also supplement direct diagnosis methods based on detecting the presence of bacterial cells, such as culturing and PCR.

\subsection{Conclusions}

This study utilized a novel variation of the SELEX process, Decoy-SELEX, to obtain a ssDNA Molecular Recognition Element specific for Exotoxin A, a virulence factor of Pseudomonas aeruginosa. The MRE is characterized to have high affinity and specificity to its target, thus validating the Decoy-SELEX methodology. Utilizing surface plasmon resonance measurements, the determined equilibrium dissociation constant $\left(\mathrm{K}_{\mathrm{d}}\right)$ of the MRE is between 4.2 $\mu \mathrm{M}$ and $4.5 \mu \mathrm{M}$, and is highly selective for Exotoxin A over negative targets. A ssDNA MRE modified sandwich enzyme-linked immunosorbent assay (ELISA) has been developed and achieved a sensitive detection of Exotoxin A at nanomolar concentrations in human serum. This study has demonstrated the proof-of-principle of using ssDNA MRE as a potential clinical diagnostic tool. 


\subsection{References}

1. Pavlovskis, O.R. and F.B. Gordon, Pseudomonas aeruginosa exotoxin: effect on cell cultures. J Infect Dis, 1972. 125(6): p. 631-6.

2. Ballok, A.E. and G.A. O'Toole, Pouring salt on a wound: Pseudomonas aeruginosa virulence factors alter $\mathrm{Na}+$ and $\mathrm{Cl}$ - flux in the lung. J Bacteriol, 2013. 195(18): p. 4013-9.

3. Gomez, M.I. and A. Prince, Opportunistic infections in lung disease: Pseudomonas infections in cystic fibrosis. Curr Opin Pharmacol, 2007. 7(3): p. 244-51.

4. Bennett, G., C. Dealey, and J. Posnett, The cost of pressure ulcers in the UK. Age Ageing, 2004. 33(3): p. 230-5.

5. Nichols, D.P., et al., Effects of azithromycin in Pseudomonas aeruginosa burn wound infection. J Surg Res, 2013. 183(2): p. 767-76.

6. Gu, M., J. Rappaport, and S.H. Leppla, Furin is important but not essential for the proteolytic maturation of gp160 of HIV-1. FEBS Lett, 1995. 365(1): p. 95-7.

7. Leppla, S.H., Large-scale purification and characterization of the exotoxin of Pseudomonas aeruginosa. Infect Immun, 1976. 14(4): p. 1077-86.

8. Wedekind, J.E., et al., Refined crystallographic structure of Pseudomonas aeruginosa exotoxin A and its implications for the molecular mechanism of toxicity. J Mol Biol, 2001. 314(4): p. 823-37.

9. $\quad$ Gill, D.M., Bacterial toxins: a table of lethal amounts. Microbiol Rev, 1982. 46(1): p. 8694.

10. Iglewski, B.H. and J.C. Sadoff, Toxin inhibitors of protein synthesis: production, purification, and assay of Pseudomonas aeruginosa toxin A. Methods Enzymol, 1979. 60: p. 780-93.

11. Louis, D., P. Sorlier, and J. Wallach, Quantitation and enzymatic activity of the alkaline protease from Pseudomonas aeruginosa in culture supernatants from clinical strains. Clin Chem Lab Med, 1998. 36(5): p. 295-8.

12. Morita, Y., J. Tomida, and Y. Kawamura, Responses of to antimicrobials. Front Microbiol, 2014. 4: p. 422.

13. De Vos, D., et al., Direct detection and identification of Pseudomonas aeruginosa in clinical samples such as skin biopsy specimens and expectorations by multiplex PCR based on two outer membrane lipoprotein genes, oprI and oprL. J Clin Microbiol, 1997. 35(6): p. 1295-9.

14. Lavenir, R., et al., Improved reliability of Pseudomonas aeruginosa PCR detection by the use of the species-specific ecfX gene target. J Microbiol Methods, 2007. 70(1): p. 20-9.

15. Motoshima, M., et al., Rapid and accurate detection of Pseudomonas aeruginosa by realtime polymerase chain reaction with melting curve analysis targeting gyrB gene. Diagn Microbiol Infect Dis, 2007. 58(1): p. 53-8.

16. Khan, A.A. and C.E. Cerniglia, Detection of Pseudomonas aeruginosa from clinical and environmental samples by amplification of the exotoxin A gene using PCR. Appl Environ Microbiol, 1994. 60(10): p. 3739-45.

17. Kolesnikov, A.V., A.V. Kozyr', and I.G. Shemyakin, The prospects for using aptamers in diagnosing bacterial infections. Molecular Genetics, Microbiology and Virology, 2012. 27(2): p. 49-55. 
18. Gaines, J.M., et al., Effect of static growth and different levels of environmental oxygen on toxA and ptxR expression in the Pseudomonas aeruginosa strain PAO1. Microbiology, 2005. 151(Pt 7): p. 2263-75.

19. Gaines, J.M., et al., Regulation of the Pseudomonas aeruginosa toxA, regA and ptxR genes by the iron-starvation sigma factor PvdS under reduced levels of oxygen. Microbiology, 2007. 153(Pt 12): p. 4219-33.

20. Gallant, C.V., et al., Pseudomonas aeruginosa cystic fibrosis clinical isolates produce exotoxin A with altered ADP-ribosyltransferase activity and cytotoxicity. Microbiology, 2000. 146 ( Pt 8): p. 1891-9.

21. El-Din, A.B., et al., Pseudomonas Aeruginosa Exotoxin A: Its Role in Burn Wound Infection, and Wound Healing.

22. Cross, A.S., et al., Evidence for the role of toxin A in the pathogenesis of infection with Pseudomonas aeruginosa in humans. J Infect Dis, 1980. 142(4): p. 538-46.

23. Moss, R.B., et al., Association of systemic immune complexes, complement activation, and antibodies to Pseudomonas aeruginosa lipopolysaccharide and exotoxin A with mortality in cystic fibrosis. Am Rev Respir Dis, 1986. 133(4): p. 648-52.

24. Tuerk, C. and L. Gold, Systematic evolution of ligands by exponential enrichment: RNA ligands to bacteriophage T4 DNA polymerase. Science, 1990. 249(4968): p. 505-10.

25. Andersson, L.O., The heterogeneity of bovine serum albumin. Biochim Biophys Acta, 1966. 117(1): p. 115-33.

26. Ganguly, N.K. and T. Kaur, Mechanism of action of cholera toxin \& other toxins. Indian J Med Res, 1996. 104: p. 28-37.

27. Nguyen, T., et al., Microfluidic aptameric affinity sensing of vasopressin for clinical diagnostic and therapeutic applications. Sensors and Actuators B: Chemical, 2011. 154(1): p. 59-66.

28. Swensen, J.S., et al., Continuous, real-time monitoring of cocaine in undiluted blood serum via a microfluidic, electrochemical aptamer-based sensor. J Am Chem Soc, 2009. 131(12): p. 4262-6.

29. Wang, H., et al., Microfluidic chip-based aptasensor for amplified electrochemical detection of human thrombin. Electrochemistry Communications, 2010. 12(2): p. 258261.

30. Zimbron, J.M., et al., A dual anchoring strategy for the localization and activation of artificial metalloenzymes based on the biotin-streptavidin technology. J Am Chem Soc, 2013. 135(14): p. 5384-8.

31. Bujacz, A., Structures of bovine, equine and leporine serum albumin. Acta Crystallogr D Biol Crystallogr, 2012. 68(Pt 10): p. 1278-89.

32. O'Neal, C.J., et al., Structural basis for the activation of cholera toxin by human ARF6GTP. Science, 2005. 309(5737): p. 1093-6.

33. Hultman, T., et al., Direct solid phase sequencing of genomic and plasmid DNA using magnetic beads as solid support. Nucleic Acids Res, 1989. 17(13): p. 4937-46.

34. Zuker, M., Mfold web server for nucleic acid folding and hybridization prediction. Nucleic Acids Res, 2003. 31(13): p. 3406-15.

35. Ashley, J. and S.F. Li, An aptamer based surface plasmon resonance biosensor for the detection of bovine catalase in milk. Biosens Bioelectron, 2013. 48: p. 126-31. 
36. Liu, Y. and W.D. Wilson, Quantitative analysis of small molecule-nucleic acid interactions with a biosensor surface and surface plasmon resonance detection. Methods Mol Biol, 2010. 613: p. 1-23.

37. Duan, N., et al., Selection, identification and application of a DNA aptamer against Listeria monocytogenes. Food Control, 2013. 33(1): p. 239-243.

38. Lee, S.J., et al., ssDNA aptamer-based surface plasmon resonance biosensor for the detection of retinol binding protein 4 for the early diagnosis of type 2 diabetes. Anal Chem, 2008. 80(8): p. 2867-73.

39. Tran, D.T., et al., Selection of aptamers against Ara $h 1$ protein for FO-SPR biosensing of peanut allergens in food matrices. Biosens Bioelectron, 2013. 43: p. 245-51.

40. Wang, R., et al., Selection and characterization of DNA aptamers for use in detection of avian influenza virus H5N1. J Virol Methods, 2013. 189(2): p. 362-9.

41. Pollet, J., et al., Fiber optic SPR biosensing of DNA hybridization and DNA-protein interactions. Biosens Bioelectron, 2009. 25(4): p. 864-9.

42. Chang, C.C., et al., Amplified surface plasmon resonance immunosensor for interferongamma based on a streptavidin-incorporated aptamer. Biosens Bioelectron, 2012. 37(1): p. 68-74.

43. Park, J.W., et al., An ultra-sensitive detection of a whole virus using dual aptamers developed by immobilization-free screening. Biosens Bioelectron, 2014. 51: p. 324-9.

44. Katsamba, P.S., S. Park, and I.A. Laird-Offringa, Kinetic studies of RNA-protein interactions using surface plasmon resonance. Methods, 2002. 26(2): p. 95-104.

45. Shoji, A., et al., Modified DNA aptamer that binds the (R)-isomer of a thalidomide derivative with high enantioselectivity. J Am Chem Soc, 2007. 129(5): p. 1456-64.

46. White, R.R., B.A. Sullenger, and C.P. Rusconi, Developing aptamers into therapeutics. J Clin Invest, 2000. 106(8): p. 929-34.

47. Park, J.W., et al., Rapid and sensitive detection of Nampt (PBEF/visfatin) in human serum using an ssDNA aptamer-based capacitive biosensor. Biosens Bioelectron, 2012. 38(1): p. 233-8.

48. Bruno, J.G. and J.L. Kiel, Use of magnetic beads in selection and detection of biotoxin aptamers by electrochemiluminescence and enzymatic methods. Biotechniques, 2002. 32(1): p. 178-80, 182-3.

49. Choi, J.S., et al., Screening and characterization of high-affinity ssDNA aptamers against anthrax protective antigen. J Biomol Screen, 2011. 16(2): p. 266-71.

50. Patel, D.J., et al., Structure, recognition and adaptive binding in RNA aptamer complexes. J Mol Biol, 1997. 272(5): p. 645-64.

51. Dayton, S., et al., Composition of lipids in human serum and adipose tissue during prolonged feeding of a diet high in unsaturated fat. J Lipid Res, 1966. 7(1): p. 103-11.

52. Furuya, N., et al., Mortality rates amongst mice with endogenous septicaemia caused by Pseudomonas aeruginosa isolates from various clinical sources. J Med Microbiol, 1993. 39(2): p. 141-6.

53. Hirakata, Y., et al., In vivo production of exotoxin A and its role in endogenous Pseudomonas aeruginosa septicemia in mice. Infect Immun, 1993. 61(6): p. 2468-73.

54. Jaffar-Bandjee, M.C., et al., Production of elastase, exotoxin A, and alkaline protease in sputa during pulmonary exacerbation of cystic fibrosis in patients chronically infected by Pseudomonas aeruginosa. J Clin Microbiol, 1995. 33(4): p. 924-9. 
55. Woods, D.E., et al., Phenotypic comparison of Pseudomonas aeruginosa strains isolated from a variety of clinical sites. J Clin Microbiol, 1986. 24(2): p. 260-4.

56. Bjorn, M.J., et al., Effect of iron on yields of exotoxin A in cultures of Pseudomonas aeruginosa PA-103. Infect Immun, 1978. 19(3): p. 785-91.

57. Bjorn, M.J., P.A. Sokol, and B.H. Iglewski, Influence of iron on yields of extracellular products in Pseudomonas aeruginosa cultures. J Bacteriol, 1979. 138(1): p. 193-200.

58. Chung, D.W. and R.J. Collier, Enzymatically active peptide from the adenosine diphosphate-ribosylating toxin of Pseudomonas aeruginosa. Infect Immun, 1977. 16(3): p. 832-41.

59. You, K., et al., Aptamers as functional nucleic acids:In vitro selection and biotechnological applications. Biotechnology and Bioprocess Engineering, 2003. 8(2): p. 64-75. 


\section{Chapter 3}

\section{In Vitro Selection of a Single-Stranded DNA Molecular Recognition Element Against Clostridium difficile Toxin B and Sensitive Detection in Human Fecal Matter}

This chapter is adapted from the work that has been published in Journal of Nucleic Acids.

Citation: Hong KL, Maher E, Williams RM, Sooter LJ (2015) In Vitro Selection of a SingleStranded DNA Molecular Recognition Element Against Clostridium difficile Toxin B and Sensitive Detection in Human Fecal Matter. Journal of Nucleic Acids, vol. 2015, Article ID 808495, 12 pages. doi:10.1155/2015/808495 


\subsection{Introduction}

Toxin B is a virulence factor secreted by Clostridium difficile, an obligate anaerobic spore-forming gram positive bacillus bacterium [1]. Clostridium difficile induced diarrhea accounts for more than 300,000 or almost $30 \%$ of all cases of diarrhea in acute care settings [2, 3]. It also causes prolonged hospital stays and therefore increased cost burden in the health care system [4]. It has been reported that the cost of $C$. difficile infections are between $\$ 436$ million and $\$ 3.2$ billion per year in the US $[4,5]$. In addition to economic burdens, the mortality rates of C. difficile infections have also increased from 5.7 per million in 1999 to 23.7 per million in $2004[6]$.

C. difficile produces two major exotoxins: toxin A and toxin B. Toxin B has been shown to be 1000 times more toxic than toxin A. While both toxins are considered to be the cause of $C$. difficile colitis, all toxin-producing strains of $C$. difficile produce toxin B [7]. Upon colonization of toxic strains of $C$. difficile in the colon, produced toxins deactivate GTPases, such as Rho and Rac, disrupt cytoskeleton and signal transductions, and result in cell rounding and loss of cell structures, leading to host inflammatory responses [8].

Due to the problems associated with $C$. difficile infection (CDI), early and accurate diagnosis is important for disease management and patient survival [9]. Currently, diagnostic tests for CDI are stool culturing, cell cytotoxicity neutralization assay, enzyme immunoassay (EIA) for toxin $\mathrm{A}$ and $\mathrm{B}$, detection of $C$. difficile glutamate dehydrogenase (GDH) and polymerase chain reaction (PCR) detection of $C$. difficile genes [10]. Culturing diagnosis is very sensitive, but the turnaround time can be up to 3-5 days [11]. GDH testing is very sensitive, but is not specific and requires additional EIA for toxin $\mathrm{A}$ and/ or toxin $\mathrm{B}[11,12]$. There are multiple commercial EIA kits for toxin A/B detection on the market, but their sensitivities vary 
and they may not be available in all countries [13]. PCR test has a rapid turnaround with good sensitivity and specificity, but does not detect the presence of virulence factors and the cost associated with the test may limit its usage [11, 14]. A confirmed diagnosis of CDI usually requires positive results from two or three-step of the available tests $[15,16]$. When the results of these tests are combined, they are sensitive and specific, but excessive cost and turnaround time are major drawbacks. Therefore, it is important to identify new diagnostic techniques that can address some of these limitations.

One potential method of addressing problems associated with toxin B testing is through molecular recognition and detection. Molecular recognition elements (MREs) are defined to have high specificity and affinity toward user defined targets. Molecules such as single-stranded oligoneucleotides, small peptides, antibody fragments and full length antibodies can all participate in molecular recognition, and have been studied in different types of biosensors [1720]. MREs are identified by an in vitro selection process called, Systematic Evolution of Ligands by Exponential Enrichment (SELEX), which was first described by the Gold laboratory in 1990 [21]. Nucleic acid MREs are usually selected from a large random library consisting of $10^{13}$ to $10^{15}$ different single-stranded DNA (ssDNA) or RNA molecules. The library is enriched through repeated cycles of incubation with the desired target and subsequently removal of molecules that bind to undesired targets. At the end of the selection process, the diversity of the MRE library is decreased to the point that one or a few candidate MREs can be identified for affinity and specificity screening against the target of interest.

In this study, we applied a stringent SELEX scheme to obtain a ssDNA MRE that binds to toxin B with high affinity and specificity [22-24]. The selection scheme was designed to eliminate MREs that bind to negative targets that are likely to co-exist in the target environment. 
Bovine serum albumin (BSA) was chosen to be the first negative target based on its similarity to human serum albumin and it's prevalence as a blocking agent in assay applications [25]. Alpha toxin of Staphylococcus aureus and exotoxin A of Pseudomonas aeruginosa are virulence factors of common nosocomial infections, which have the likelihoods to co-infect hospitalized patients [26-28]. Cholera toxin of Vibrio cholerae is the causative agent of cholera induced watery diarrhea, which symptomatically mimics CDI [29]. In addition to the selection and characterization of the toxin B specific ssDNA MRE, a modified enzyme-linked immunoassay (ELISA) has been developed which utilizes the identified ssDNA MRE. The assay was able to show the detection of toxin B in human fecal samples at nanomolar concentrations. This work shows the potential of using ssDNA MREs in diagnostic applications [30-32].

\subsection{Materials and Methods}

\subsubsection{In vitro Selection of Toxin B-specific MREs}

The selection process began with a single-stranded DNA (ssDNA) library consisting of $10^{15}$ different molecules designed by our laboratory as previously described (Figure 3.1) [22]. In brief, the library, termed RMW.N34, consists of two 23-base constant regions for polymerase chain reaction (PCR) amplification, flanking a 34-base random region (commercially synthesized by Eurofins MWG Operon; Huntsville, AL). A total of 12 rounds of SELEX were performed (Table 3.1) to identify ssDNA molecules that bound specifically to toxin B and not to negative targets (Figure 3.2). 


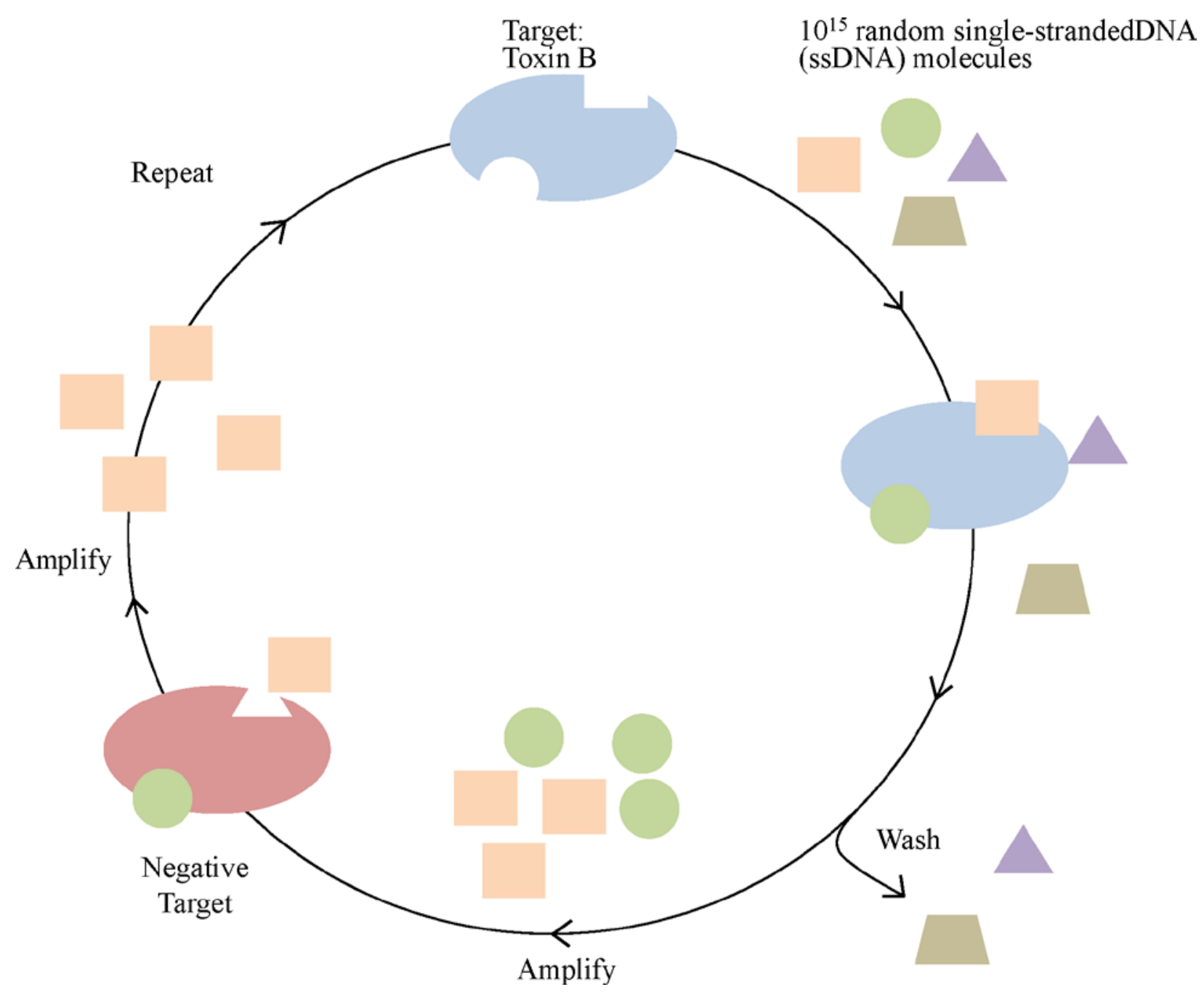

Figure 3.1: Illustration of the SELEX process. The SELEX process begins with $10^{15}$ ssDNA molecules and incubation with the target toxin B. Those that bind to toxin B is amplified and subsequently incubated with negative targets. Those that do not bind to negative targets are retained and amplified, thus completing one round of in vitro selection. 
Table 3.1: Systematic Evolution of Ligands by Exponential Enrichments (SELEX) scheme for Toxin B-specific MRE selection.

\begin{tabular}{|c|c|c|c|c|}
\hline Round & Positive Selection & Time & Negative Selection & Time \\
\hline 1 & $\begin{array}{ll}\text { Immobilized } & \text { Target } \\
\text { (IT) } & \end{array}$ & 24 hrs & - & - \\
\hline 2 & IT & $18 \mathrm{hrs}$ & BSA INT & $22 \mathrm{hrs}$ \\
\hline 3 & IT & $13 \mathrm{hrs}$ & BSA INT & $26 \mathrm{hrs}$ \\
\hline 4 & IT & $7 \mathrm{hrs}$ & Exotoxin A INT & $22 \mathrm{hrs}$ \\
\hline 5 & IT & $3 \mathrm{hrs}$ & Exotoxin A INT & $26 \mathrm{hrs}$ \\
\hline 6 & IT & $30 \mathrm{~min}$ & BSA INT & $24 \mathrm{hrs}$ \\
\hline \multirow[t]{2}{*}{7} & IT/ & $5 \mathrm{~min} /$ & IT/ & $5 \mathrm{~min} /$ \\
\hline & $\begin{array}{l}\text { Competitive Elution } \\
\text { with } 20 \mu \mathrm{g} / \mathrm{mL} \text { free } \\
\text { toxin } \mathrm{B}\end{array}$ & $5 \mathrm{~min}$ & $\begin{array}{l}\text { Competitive Elution } \\
\text { with } 20 \mu \mathrm{g} / \mathrm{mL} \text { free } \\
\text { BSA }\end{array}$ & $5 \mathrm{~min}$ \\
\hline \multirow[t]{2}{*}{8} & IT/ & $5 \mathrm{sec} /$ & IT/ & $5 \mathrm{sec} /$ \\
\hline & $\begin{array}{l}\text { Competitive Elution } \\
\text { with } 20 \mu \mathrm{g} / \mathrm{mL} \text { free } \\
\text { toxin B }\end{array}$ & $5 \mathrm{sec}$ & $\begin{array}{l}\text { Competitive Elution } \\
\text { with } 20 \mu \mathrm{g} / \mathrm{mL} \text { free } \\
\text { alpha toxin, } 1 \text { hour }\end{array}$ & $1 \mathrm{hrs}$ \\
\hline \multirow[t]{2}{*}{9} & IT/ & $5 \mathrm{sec} /$ & IT/ & $5 \mathrm{sec} /$ \\
\hline & $\begin{array}{l}\text { Competitive Elution } \\
\text { with } 10 \mu \mathrm{g} / \mathrm{mL} \text { free } \\
\text { toxin B }\end{array}$ & $5 \mathrm{sec}$ & $\begin{array}{l}\text { Competitive Elution } \\
\text { with } 20 \mu \mathrm{g} / \mathrm{mL} \text { free } \\
\text { cholera toxin, } 1 \text { hour }\end{array}$ & $1 \mathrm{hrs}$ \\
\hline \multirow[t]{2}{*}{10} & IT/ & $5 \mathrm{sec} /$ & IT/ & $5 \mathrm{sec} /$ \\
\hline & $\begin{array}{l}\text { Competitive Elution } \\
\text { with } 5 \mu \mathrm{g} / \mathrm{mL} \text { free } \\
\text { toxin B }\end{array}$ & $5 \mathrm{sec}$ & $\begin{array}{l}\text { Competitive Elution } \\
\text { with } 20 \mu \mathrm{g} / \mathrm{mL} \text { free } \\
\text { exotoxin } \mathrm{A}, 1 \text { hour }\end{array}$ & $1 \mathrm{hrs}$ \\
\hline \multirow[t]{2}{*}{11} & IT/ & $5 \mathrm{sec} /$ & IT/ & $5 \mathrm{sec} /$ \\
\hline & $\begin{array}{l}\text { Competitive Elution } \\
\text { with } 2.5 \mu \mathrm{g} / \mathrm{mL} \text { free } \\
\text { toxin } \mathrm{B}\end{array}$ & $5 \mathrm{sec}$ & $\begin{array}{l}\text { Competitive Elution } \\
\text { with } 20 \mu \mathrm{g} / \mathrm{mL} \text { free } \\
\text { BSA, } 24 \mathrm{hrs}\end{array}$ & $24 \mathrm{hrs}$ \\
\hline 12 & $\begin{array}{l}\text { IT/ } \\
\text { Competitive Elution } \\
\text { with } 1 \mu \mathrm{g} / \mathrm{mL} \text { free } \\
\text { toxin B }\end{array}$ & $\begin{array}{l}5 \mathrm{sec} / \\
5 \mathrm{sec}\end{array}$ & - & \\
\hline
\end{tabular}

In vitro selection performed for identifying toxin B-specific MRE. Immobilized target (IT) is toxin B conjugated to magnetic beads. Immobilized negative target (INT) is negative targets conjugated to magnetic beads. BSA is the abbreviation for bovine serum albumin. Times listed are incubation times in hours (hrs), minutes (min) or seconds (sec). 
(A) Toxin B

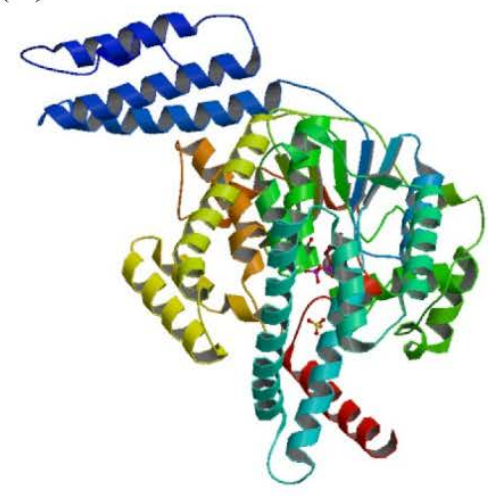

(C) Bovine Serum Albumin

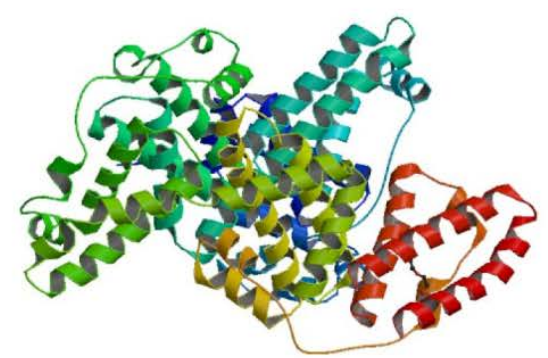

(B) Exotoxin A

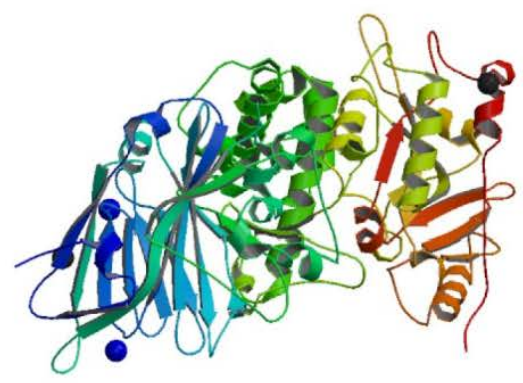

(E) Alpha Toxin

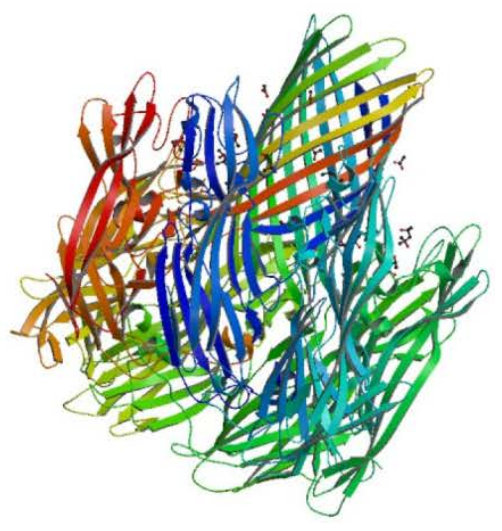

Figure 3.2: Structures of targets used in the SELEX scheme and cross binding assays. (A) Ribbon structure of the selection target, Clostridium difficile toxin B (PDB 2BVM, $270 \mathrm{kDa}$ ) [33]. (B), (C), (D), (E) Ribbon structure of Pseudomonas aeruginosa exotoxin A (PDB 1IKQ, 66 $\mathrm{kDa}$ ) [34], bovine serum albumin (PDB 4F5S, $66.5 \mathrm{kDa}$ ) [35], Vibrio cholerae cholera toxin (PDB 2A5D, $84 \mathrm{kDa}$ ) [36], and Staphylococcus aureus alpha toxin (PDB 3ANZ, $33 \mathrm{kDa}$ ) [37], used in negative rounds of selection and cross binding assays.

Lyophilized toxin B (List Biological Laboratories; Campbell, CA) was reconstituted in pure water and covalently immobilized to carboxylic acid-coated magnetic beads (Dynabeads M270 Carboxylic Acid, Life Technologies; Grand Island, NY) via an amidation reaction using N- 
hydroxysulfonyl succinimide (sulfo-NHS) (Pierce; Rockford, IL) and 1-ethyl-3-(3dimethylaminopropyl) (EDC) (Pierce; Rockford, IL) according to manufacturer’s protocol.

For positive rounds, $6 \mu \mathrm{L}$ of immobilized target was incubated with ssDNA library in 200 $\mu \mathrm{L}$ of selection buffer composed of $100 \mathrm{mM}$ sodium chloride, $20 \mathrm{mM}$ Tris- $\mathrm{HCl}$, and $2 \mathrm{mM}$ magnesium chloride ( $1 \times$ selection buffer, SB) at room temperature with rotation $(8 \mathrm{RPM})$. After incubation, the immobilized target and solution were separated using a magnet. Unbound ssDNA in solution was removed. Immobilized target/ DNA complexes were washed three times with $200 \mu \mathrm{L}$ of SB and resuspended in $100 \mu \mathrm{L}$ of SB. This bound DNA served as a template for PCR amplification. The PCR conditions were as follows: bound ssDNA, $400 \mathrm{nM}$ forward and biotinylated reverse RMW.N34 primers (Eurofins MWG Operon; Huntsville, AL) (forward: 5'TGTACCGTCTGAGCGATTCGTAC-3', biotinylated reverse: 5'-BiotinGCACTCCTTAACACTGACTGGCT-3'), $250 \mu \mathrm{M}$ deoxynucleotide triphosphates, $1 \times$ GoTaq Reaction Buffer (Promega; Madison, WI), 3.5 units Taq polymerase, and pure water. Thermal cycling conditions were as follows: denature at $95^{\circ} \mathrm{C}$ for 5 minutes, cycle at $95^{\circ} \mathrm{C}$ for 1 minute, $63^{\circ} \mathrm{C}$ for 45 seconds, and $72^{\circ} \mathrm{C}$ for 1 minute; and final extension temperature at $72^{\circ} \mathrm{C}$ for 7 minutes [22].A large-scale 3mL amplification was carried out after each round of positive and negative selection. This selection procedure for the immobilized toxin B target was performed for Rounds $1-6$, each with decreasing incubation time.

After PCR amplification, amplified dsDNA was purified with the IBI PCR purification kit (IBI Scientific; Peosta, IA) according to the manufacturer's protocol. Eluted dsDNA containing the biotinylated reverse strand was subjected to single strand separation and ethanol precipitation of the forward strand as previously described [22]. This procedure was performed after each positive and negative round of selection. 
For negative rounds, multiple negative targets were covalently immobilized to carboxylic acid-coated magnetic beads as described above. Immobilized negative targets were incubated with the enriched ssDNA library in the same conditions as positive rounds. However, after magnetic separation, unbounded ssDNA in solution was used as template for PCR amplification. This selection procedure for immobilized negative targets was performed for Rounds $2-6$.

Competitive elution with free toxin B in solution was performed beginning in Round 7 positive. The enriched ssDNA library was first incubated with immobilized toxin B as described above. After magnetic separation and washes, toxin B at a concentration of $20 \mu \mathrm{g} / \mathrm{mL}$ in $100 \mu \mathrm{L}$ of $1 \times$ SB was added to magnetic beads and incubated for 5 minutes, then subjected to magnetic separation. The solution containing ssDNA bound to free toxin B served as PCR template. This procedure was performed for Rounds $7-12$ positive, each with decreasing time of incubation and target concentrations.

Similarly, competitive elution with negative targets in solution was performed beginning in Round 7 negative as outlined above. However, ssDNA molecules bound to the immobilized target were resuspended in $100 \mu \mathrm{L}$ of $1 \times$ selection buffer and served as PCR template. This procedure was performed for Rounds 7 - 11 negative.

\subsubsection{Cloning and Sequencing of Toxin B-specific MREs}

In order to analyze the ssDNA library for consensus binding sequences, the library was cloned and sequenced following Rounds 3 negative, 6 negative, 9 negative and 12 positive. Identical procedures were performed as previously described [22]. In brief, the library was amplified with non-biotinylated primers, and the fresh PCR product was ligated into the pCRII vector (Invitrogen; Carlsbad, CA) and cloned into competent E. coli according to the manufacturer's protocol. The cloned plasmid was extracted and purified with AxyPrep Plasmid 
Miniprep kit (Axygen; Union City, CA), and subsequently sequenced with the M13R primer by commercial source (Eurofins MWG Operon; Huntsville, AL). A total of 30-80 randomly selected clones were sequenced and analyzed.

\subsubsection{Toxin B-specific MREs Sequence Alignment and Analysis}

Sequences were first grouped into super-families by analyzing common tetranucleotide sequence from the variable regions of sequenced clones. The largest super-family was then chosen for alignment and divided into smaller subfamilies. All sequences in the subfamilies were analyzed for their predicted secondary structures, the predicted Gibbs free energy values of those structures, and percent homology. These analyzed parameters were considered in the choice of candidate sequences.

\subsubsection{Toxin B-specific MRE Binding Assays with Surface Plasmon Resonance}

One candidate sequence from the round 12 library was chosen for further characterization. The candidate sequence was designated as R12.69. The secondary structure was predicted by the Mfold DNA web server using the following conditions: $25^{\circ} \mathrm{C}, 100 \mathrm{mM} \mathrm{Na}{ }^{+}$, and $2 \mathrm{mM} \mathrm{Mg}^{2+}$ [38]. Commercially synthesized 5’amino-C6 modified R12.69 (5' amino-C6 indicates a primary amino group attached to the 5' end of the oligonucleotide with six carbon spacer between the two) (Eurofins MWG Operon; Huntsville, AL) was used for surface plasmon resonance (SPR) affinity assays. Both in-house produced and commercially purchased CM5 (GE Healthcare; Piscataway, NJ) SPR sensor chips were used for binding assays.

Home-made gold chips were fabricated from glass slides $(12 \mathrm{~mm}$ x $10 \mathrm{~mm})$ coated with a $2 \mathrm{~nm}$ titanium adhesion layer and a $45 \mathrm{~nm}$ gold layer. Metals were deposited using a Temescal BJD-2000 system (Edwards Vacuum; Phoenix, AZ) with an Inficon XTC/2 deposition controller 
(East Syracuse, NY). The home-made gold chips were first cleaned in $100 \%$ ethanol under sonication for 5 minutes, then immersed in a solution of $10 \mathrm{mM}$ 11-mercaptoundecanoic acid (11-MUA) (Sigma; St. Louis, MO) and $10 \mathrm{mM}$ triethylene glycol mono-11mercaptoundecylether (PEG3) (Sigma) in a 1 to 5 ratio overnight under argon for the formation of the self-assembled monolayer. Subsequently, gold chips were rinsed in $100 \%$ ethanol and pure water, blown dry with nitrogen and assembled onto carrying cartridges for SPR binding assays using a Biacore X100 (GE Healthcare; Piscataway, NJ).

Both in-house produced and purchased CM5 SPR sensor chips were activated by injecting 100 mM N-hydroxysulfonyl succinimide (sulfo-NHS) (Pierce; Rockford, IL) and 400 mM 1-ethyl-3-(3-dimethylaminopropyl) (EDC) (Pierce; Rockford, IL) at a 1 to 1 ratio to both active (flow cell 2) and reference (flow cell 1) flow cells at a flow rate of $5 \mu \mathrm{L} / \mathrm{min}$ for ten minutes. An immobilization buffer composed $100 \mathrm{mM}$ sodium chloride, $20 \mathrm{mM}$ potassium phosphate, and $2 \mathrm{mM}$ magnesium chloride, $\mathrm{pH} 7.4$ was used as the running buffer. Then, $300 \mu \mathrm{L}$ of 100 nM 5' amino-C6modified R12.69 in immobilization buffer was injected into the active flow cell at a flow rate of $5 \mu \mathrm{L} / \mathrm{min}$, followed by 10 minutes injection of $1 \mathrm{M}$ ethanolamine-HCl pH 8.5 into both active and reference flow cells in order to inactivate un-reacted sensor surface. Maximum levels of immobilization were obtained for affinity analyses.

Single cycle kinetics assays were performed to determine the affinity of R12.69 to toxin B. The $1 \times$ selection buffer was used as running buffer during kinetics assays. Toxin $B$ at various concentrations (20 nM, $40 \mathrm{nM}, 60 \mathrm{nM}, 100 \mathrm{nM}$ and $200 \mathrm{nM}$ ) in 1× SB were injected into both flow cells at a flow rate of $30 \mu \mathrm{L} / \mathrm{min}$ for 120 seconds with a dissociation time of 150 seconds. Control and baseline adjusted sensorgram responses were analyzed with the Biacore X100 evaluation software (GE Healthcare; Piscataway, NJ). A 1:1 kinetics model was used to 
determine the equilibrium dissociation constant $\left(\mathrm{K}_{\mathrm{d}}\right)$. This binding assay was performed in triplicate.

\subsubsection{Toxin B-specific MRE Fluorescence Cross-Binding Assays}

To determine the cross binding activities of the selected MRE, 5'FAM modified R12.69 was purchased from Eurofins MWG Operon. The assay was performed as previously described with slight modifications [39]. Toxin B, exotoxin A (List Biological Laboratories; Campbell, CA), alpha toxin (List Biological Laboratories; Campbell, CA), cholera toxin (List Biological Laboratories; Campbell, CA), and BSA at $40 \mathrm{nM}$ in $90 \mu \mathrm{L}$ of $50 \mathrm{mM}$ carbonate/ bicarbonate buffer (pH 9.6) were added into individual wells of a 96 well Nunc C8 Lockwell MaxiSorp microplate (Pierce; Rockford, IL). Wells containing $1 \times$ SB with $0.05 \%$ Tween-20 served as the negative background control. The plate was placed on a shaker and incubated at $4{ }^{\circ} \mathrm{C}$ overnight for protein coating (500 RPM). Subsequently, wells were blocked with $90 \mu \mathrm{L}$ of $1 \times$ SB with $0.05 \%$ Tween-20 for 1 hour and washed with the same blocking buffer 3 times. Fluorescently labeled R12.69 was diluted to $100 \mathrm{nM}$ in $90 \mu \mathrm{L}$ of $1 \times$ SB. It was then added to each well and incubated at room temperature for 1 hour. Unbound R12.69 was then aspirated and followed by washing with $1 \times$ SB 5 times. Finally, $90 \mu \mathrm{L}$ of $1 \times$ SB was added to each well and the fluorescence emission was measured by a Synergy 2 microplate reader with excitation at $490 \mathrm{~nm}$ and emission at $520 \mathrm{~nm}$ (Biotek US; Winooski, VT). Fluorescence measurements were normalized to $90 \mu \mathrm{L}$ of $100 \mathrm{nM}$ fluorescent MRE in $1 \times$ SB as described previously [22]. Protein target sets were performed in triplicate and control well sets in duplicate. All data was averaged and standard deviations were calculated. A one-tailed $t$-test was performed to determine the statistical significance in difference of the means $(p \leq 0.05)$. 


\subsubsection{Toxin B-specific MRE Modified ELISA assays}

Commercially synthesized 5' amino-C6 modified R12.69 was used as the toxin B capturing element in a modified sandwich ELISA assay. First, $40 \mathrm{nM}$ of 5' amino-C6 modified R12.69 in immobilization buffer (100 mM sodium chloride, $20 \mathrm{mM}$ potassium phosphate, and 2 $\mathrm{mM}$ magnesium chloride, $\mathrm{pH}$ 7.56) was denatured at $95^{\circ} \mathrm{C}$ for 5 min and cooled to room temperature. Then, $100 \mu \mathrm{L}$ of the ssDNA was added to individual wells of a maleic anhydride activated plate (Pierce; Rockford, IL) and incubated overnight with shaking at room temperature (500 RPM). Each well was then blocked with $0.1 \%$ BSA in $1 \times$ SB for 1 hour, and washed three times with wash buffer containing $0.1 \%$ BSA, $0.05 \%$ Tween- 20 in $1 \times$ SB at room temperature to remove non-immobilized ssDNA.

Normal human fecal samples (Lee Biosolutions; St Louis, MO) were reconstituted in 1× SB at $1 \mathrm{~g}$ to $20 \mathrm{~mL}$ ratio, then centrifuged at $5000 \mathrm{x} \mathrm{g}$ for 10 minutes to collect fecal solution. Toxin B was spiked into $100 \mu \mathrm{L}$ of prepared fecal solution and $100 \mu \mathrm{L}$ of $1 \times$ SB respectively at a final concentration of $50 \mathrm{nM}$ and served as active testing samples. Blank wells without immobilized ssDNA served as the first negative control, and $100 \mu \mathrm{L}$ of $1 \times$ phosphate buffer solution, $100 \mu \mathrm{L}$ of $1 \times \mathrm{SB}$, and $100 \mu \mathrm{L}$ of fecal solution in wells with immobilized ssDNA served as the second negative control. All samples were added to individual well and incubated for 1 hour with shaking at room temperature (500 RPM).

After sample incubation, wells were washed three times with wash buffer to remove unbound toxin B. Then, $100 \mu \mathrm{L}$ of chicken anti-toxin B primary antibody (List Biological Laboratories; Campbell, CA) at a 1 to 400 dilution ratio in wash buffer was added to each well and incubated for 30 minutes at room temperature with shaking (500 PRM). The primary antibody was then aspirated and each well was washed three times as outlined above. A 
secondary goat anti-chicken antibody conjugated to horseradish peroxidase (Pierce; Rockford, IL) at 1 to 500 dilution ratio was added and incubated for 30 minutes at room temperature with shaking (500 RPM). Lastly, all contents were aspirated and washed five times with wash buffer to remove non-specifically bound antibodies (Figure 3.3). Additional negative controls were wells without antibodies and wells with only primary antibody. Assays were performed in duplicate.

ABTS substrate (Pierce; Rockford, IL) was added to individual well according to the manufacturer's protocol. Absorbance at $410 \mathrm{~nm}$ and $650 \mathrm{~nm}$ was measured in a Synergy 2 microplate reader using Gen5 1.06 software (Biotek US; Winooski, VT) in two minute increments. All data was averaged and standard deviations were calculated. A two-tailed student $t$-test was used to determined statistical differences at $p<0.05$.

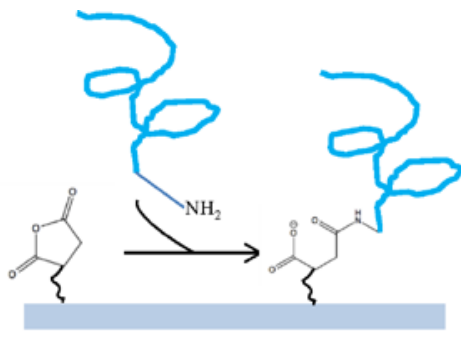

5' amino-C6 modified MRE immobilized on maleic anhydride activated microplate well

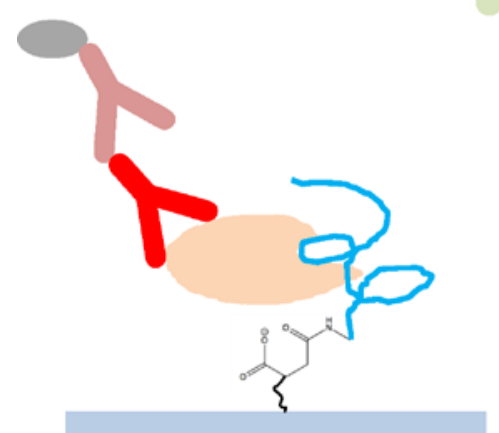

Add secondary antibody conjugated to horseradish peroxidase (HRP)

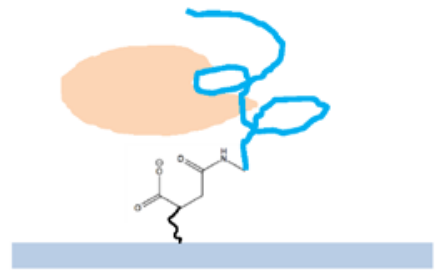

Add toxin B (not in scale)

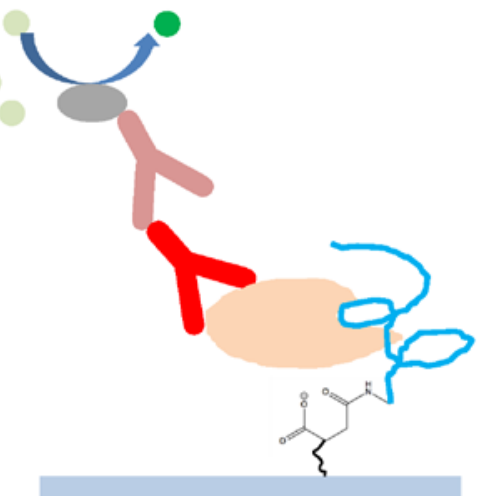

Add ABTS, substrate of (HRP)

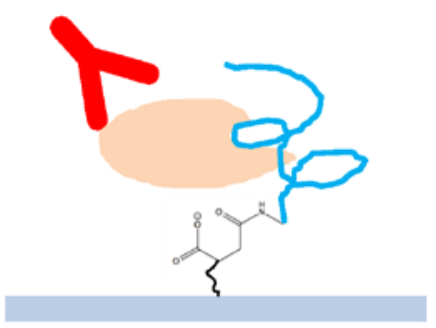

Add primary anti-toxin B antibody

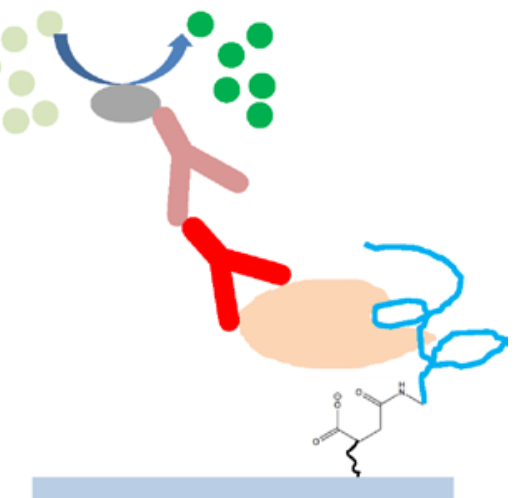

Signal is amplified and monitored over time 
Figure 3.3: Illustration of the Toxin B-specific MRE modified ELISA assay. The ssDNA MRE was used as the capturing element in the modified sandwich ELISA assay and signal is amplified by using secondary antibody conjugated to horse radish peroxidase (HRP).

\subsection{Results and Discussions}

\subsubsection{Identification of Toxin B-specific MRE}

Twelve rounds of SELEX were carried out to identify ssDNA MREs specific to toxin B. This SELEX scheme is designed to enrich ssDNA MREs that bind to toxin B in solution and exclude ssDNA molecules that bind to BSA, alpha toxin, exotoxin A, and cholera toxin, which are likely to co-exist in the target environment. Multiple negative selection rounds were performed to enhance the specificity of the ssDNA library. After every three complete rounds of selection (rounds 3, 6, 9 and 12), 30 - 80 random sequences were selected and analyzed.

In the round 12 ssDNA library, 43 sequences were successfully obtained and analyzed. The largest super-family contained 17 sequences. All 17 sequences were further aligned based on the common tetranucleotide sequence (CTAA), and divided into five smaller subfamilies (Figure 3.4). 

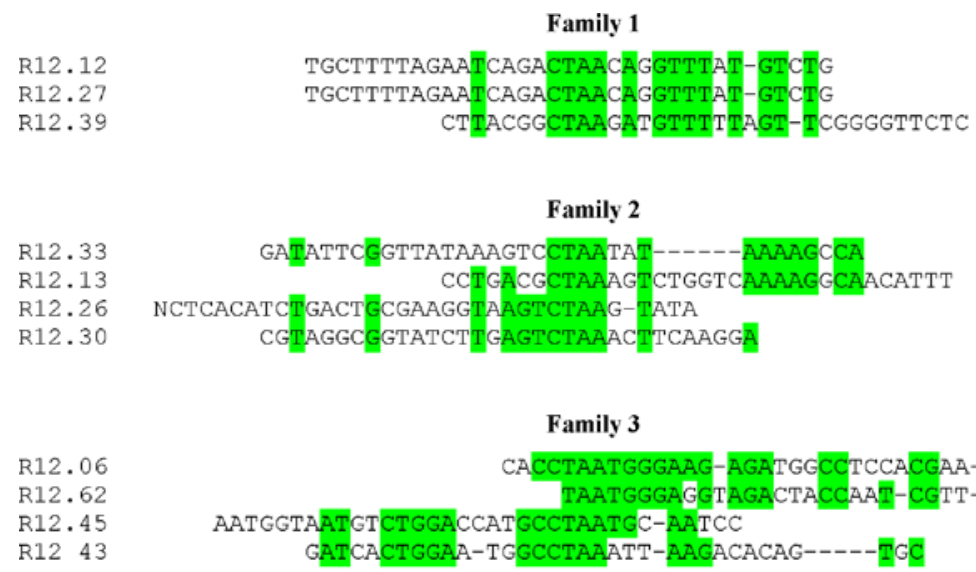

$\mathrm{R} 12.49$

R12. 66

$\mathrm{R} 12.65$

R12. 69

R12.75

R12.78

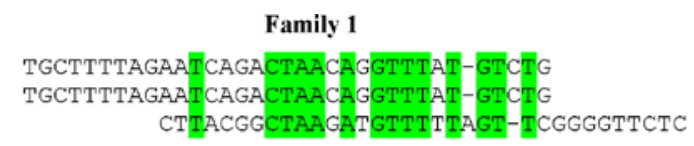

Family 3

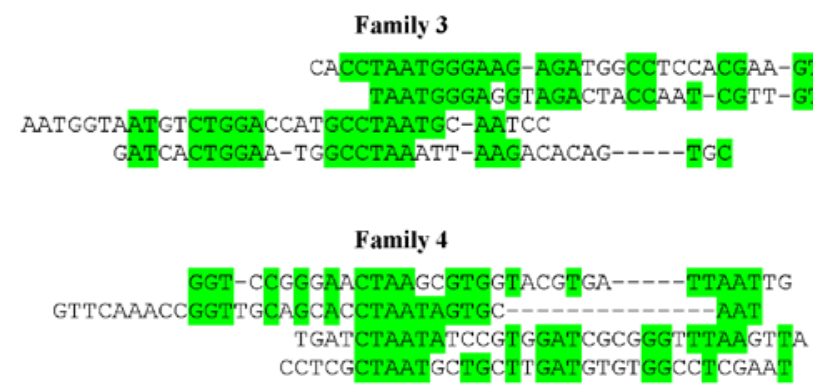

Family 5

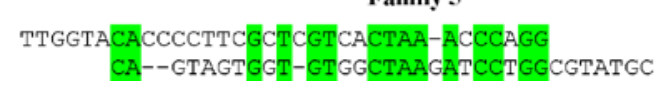

$\Delta G(\mathrm{kcal} / \mathrm{mol}) \quad$ Possible Structures

$-6.83$

$-6.83$

$-5.94$

$\Delta \mathrm{G}(\mathrm{kcal} / \mathrm{mol})$

$-3.99$

$-7.61$

$-7.05$

$-9.73$

$\Delta \mathrm{G}(\mathrm{kcal} / \mathrm{mol})$

Possible

$-7.05$

$-5.47$

-8.58
-8.27

$-8.27$

$\Delta \mathrm{G}(\mathrm{kcal} / \mathrm{mol})$

$-7.04$

$-9.92$

$-6.15$

$-8.07$

$\Delta \mathrm{G}$ (kcal/mol)

$-6.95$

$-9.88$
\% Homology

$100(34 / 34)$

$100(34 / 34)$

$41(14 / 34)$

Possible Structures

\% Homology

$41(14 / 34)$

$41(14 / 34)$

$32(11 / 34)$

$36(12 / 33)$

\% Homology

$58(23 / 34)$

$62(21 / 34)$

$50(17 / 34)$

$53(18 / 34)$

$\%$ Homology

$58(30 / 34)$

$55(18 / 33)$

$50(17 / 34)$

$44(15 / 34)$

$\%$ Homology

$44(15 / 34)$

$45(15 / 33)$

Figure 3.4: Sequence families of the round 12 library. Only the variable region is shown in the aligned subfamily of the CTAA super-family. MRE sequences are aligned to the CTAA tetranucleotide sequence. Highlighted regions represent sequence homology shared in the subfamilies. $\Delta \mathrm{G}$ represents the Gibbs free energy values. Possible structures indicate the number of predicted structures from the Mfold web server [38]. Percent homology is calculated from highlighted nucleotides divided by the length of the sequenced variable region.

It is to be noted that one sequence R12.62 only contained TAA tri-nucleotide, however it shared large homology within the subfamily, and therefore it was also included in the analysis. The CTAA tetranucleotide was not found in the constant regions, and therefore the constant regions did not participate in the family analysis, and were omitted in the figure presentation. However, previous studies showed that the constant regions of the MRE sequence can be involved in their functional secondary structures, thus they were not ignored in the overall 
decisions of choosing candidate sequences [40-44]. Two sequences, R12.12 and R12.27 were identical. However, the sequences were not chosen for further characterization based on the relatively higher Gibbs free energy value $(\Delta G)$ (indicating lower stability) and multiple possible secondary structures. Sequence R12.30, R12.66 and R12.78 had the overall lowest $\Delta \mathrm{G}$ values, but their variable regions did not sufficiently participate in the formation of stem-loop structures according to the Mfold predictions. Only one sequence, R12.69 had one possible predicted structure with a relatively low $\Delta \mathrm{G}$ value $(-8.07 \mathrm{kcal} / \mathrm{mol})$, and sufficient stem-loop structures formed from the variable region (Figure 3.5). Therefore, R12.69 was chosen for further characterization.

(A)

(B)

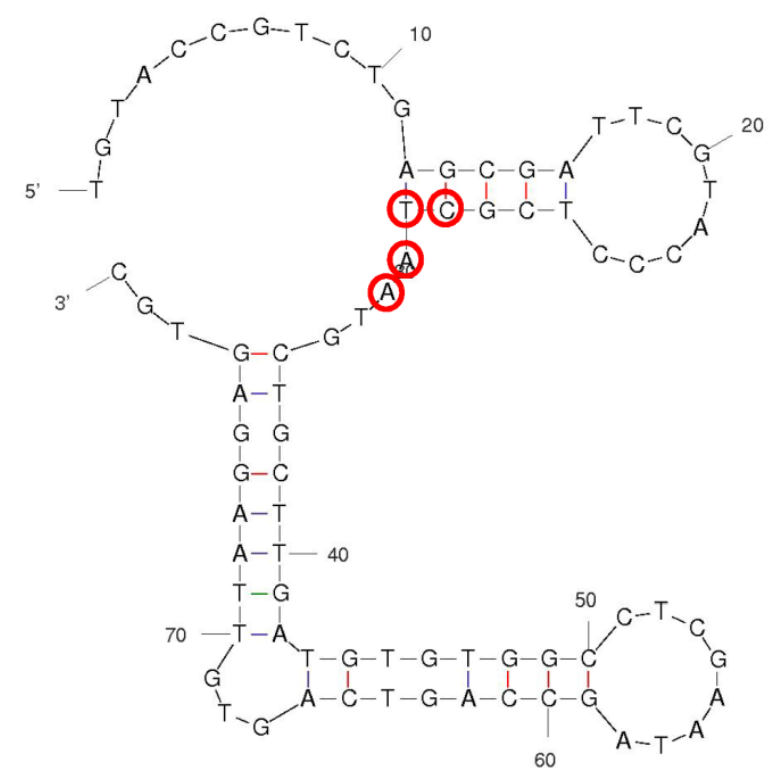

R12.69 
Figure 3.5: Secondary structure and sequence of R12.69 ssDNA MRE. (A) ssDNA sequence of toxin B MRE R12.69. The red portions indicate the constant regions for primer attachment, and the black portion indicates the variable region. (B) Mfold prediction of R12.69 secondary structure. Highlighted sequence, CTAA, represents that most common tetranucleotide sequence in the variable regions of the 43 sequences obtained from the round 12 library, and it is used as the center for sequence alignment in Figure 4 [38].

\subsubsection{Affinity and Specificity of Toxin B-specific MRE}

Surface plasmon resonance was used to determine the affinity of R12.69. Single cycle kinetics analysis was performed on both in-house produced and commercial CM5 SPR sensor chips. This type of assay was chosen instead of multi-cycle kinetics because there was no need to predetermine the regeneration condition of the sensor chip. This type of assay has also been used in previous studies to determine the binding affinities of nucleic acid MREs [45, 46]. Two assays were performed on CM5 sensor chip and one assay was performed on home-made sensor chip. There were negligible differences between the equilibrium dissociation constants $\left(\mathrm{K}_{\mathrm{d}}\right)$ obtained from both types of sensor chips. The averaged $K_{d}$ value from the three assays was determined to be $47.3 \pm 13.7 \mathrm{nM}$ (Figure 3.6).

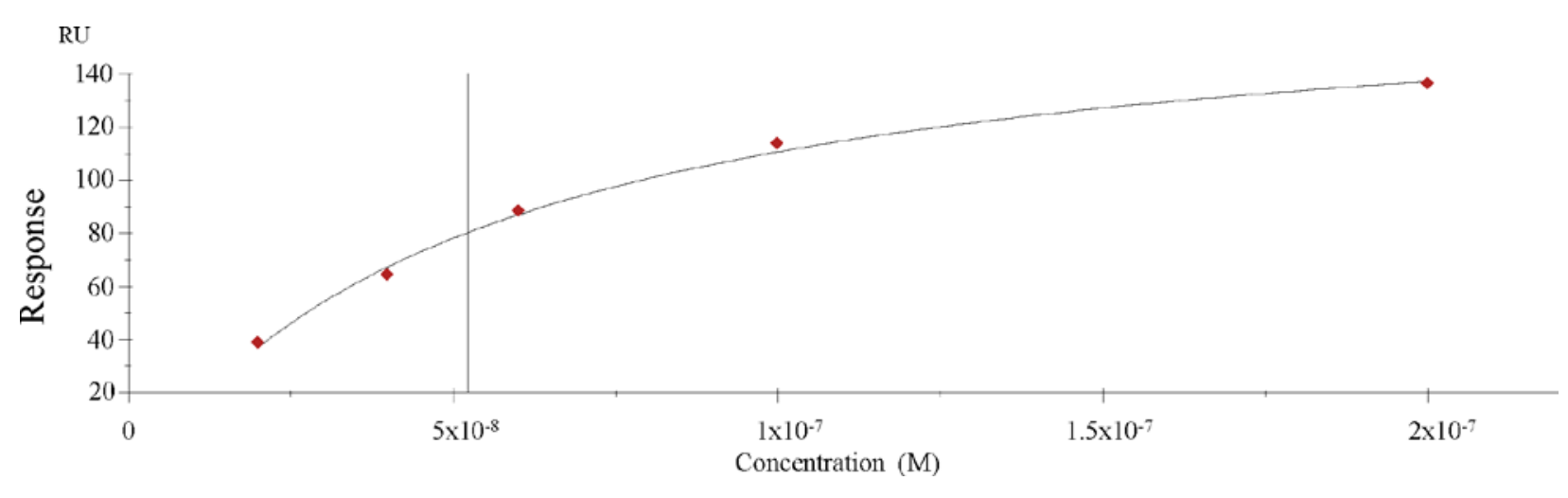


Figure 3.6: Affinity measurements of R12.69 ssDNA MRE. A representative SPR affinity saturation curve of R12.69 with 1:1 binding fit. The averaged equilibrium dissociation constant and standard error of three SPR measurements is $47.3 \pm 13.7 \mathrm{nM}$.

It is to be noted that the MRE was immobilized covalently onto the sensor chip surfaces, which was different than most of the previous studies [45, 47-49]. The surface of both homemade and CM5 sensor chips were negatively charged under a neutral to basic running buffer (IM buffer), and the electrical repulsion between the negatively charged DNA may lead to variable levels of ligand immobilization and different levels of maximum SPR response unit. However, analyte and ligand binding was saturated in all three independent assays, thus validating the use of covalent linkage for MRE immobilization in SPR analysis. The determined dissociation constant $\left(\mathrm{K}_{\mathrm{d}}\right)$ was comparable to other MREs targeting bacteria toxins [39, 50, 51].

The cross binding activity of R12.69 was determined by fluorescence plate assay. The ssDNA MRE preferably binds to toxin B greater than other negative targets in the selection scheme (Table 3.2).

Table 3.2: Cross-binding reactivity of R12.69 ssDNA MRE.

\begin{tabular}{lllll}
\hline Target & $\begin{array}{l}\text { Average } \\
\text { Fluorescence } \\
\text { (RFU) }\end{array}$ & $\begin{array}{l}\text { Standard } \\
\text { Deviation }\end{array}$ & P-value & Selectivity Ratio \\
\hline Toxin B & 0.0176 & 0.0066 & - & - \\
Cholera Toxin & 0.0080 & 0.0041 & 0.0497 & 2.2 \\
Alpha Toxin & 0.0033 & 0.0022 & 0.0117 & 5.4 \\
$\begin{array}{l}\text { Exotoxin A } \\
\text { Bovine Serum }\end{array}$ & 0.0037 & 0.0022 & 0.0130 & 4.7 \\
Albumin & 0.0030 & 0.0018 & 0.0106 & 5.8 \\
\hline
\end{tabular}


For each protein target, average fluorescence is given with standard deviation. The $P$-value is given from a $t$-test between toxin $\mathrm{B}$ and other negative targets. The selective ratio describe the number of times greater binding to toxin $\mathrm{B}$ than to other negative targets.

The binding of R12.69 to toxin B is 2.2 times higher than chorea toxin $(p=0.0497), 5.4$ times higher than alpha toxin $(p=0.0117), 4.7$ times higher than exotoxin $\mathrm{A}(p=0.0130)$, and 5.8 times higher than bovine serum albumin $(p=0.0106)$. It is to be noted that both cholera toxin (84 $\mathrm{kDa})$ and alpha toxin (33 $\mathrm{kDa})$ were introduced only once in the negative selection scheme. However, the selectivity over alpha toxin is more than double that of cholera toxin. It is likely that the ssDNA library was enriched to bind preferably to large globular protein targets (M.W. of toxin $\mathrm{B}=270 \mathrm{kDa}$ ) during early selection rounds. Other negative targets were introduced multiple times in the negative selection scheme and therefore their respective cross binding activities were sufficiently decreased. This result validates that multiple negative targets and competitive elution strategy employed in our stringent SELEX method can greatly enhance the specificity of ssDNA MREs.

\subsubsection{Diagnostic Application of Toxin B-specific MRE}

A modified sandwich ELISA assay was developed in this study to investigate the translational potential of R12.69. Reproducible detection of $50 \mathrm{nM}$ toxin B spiked in human fecal solutions were achieved compared to control in 8 minutes after HRP substrate incubation $(p<$ 0.05) (Figure 3.7). 
(A)

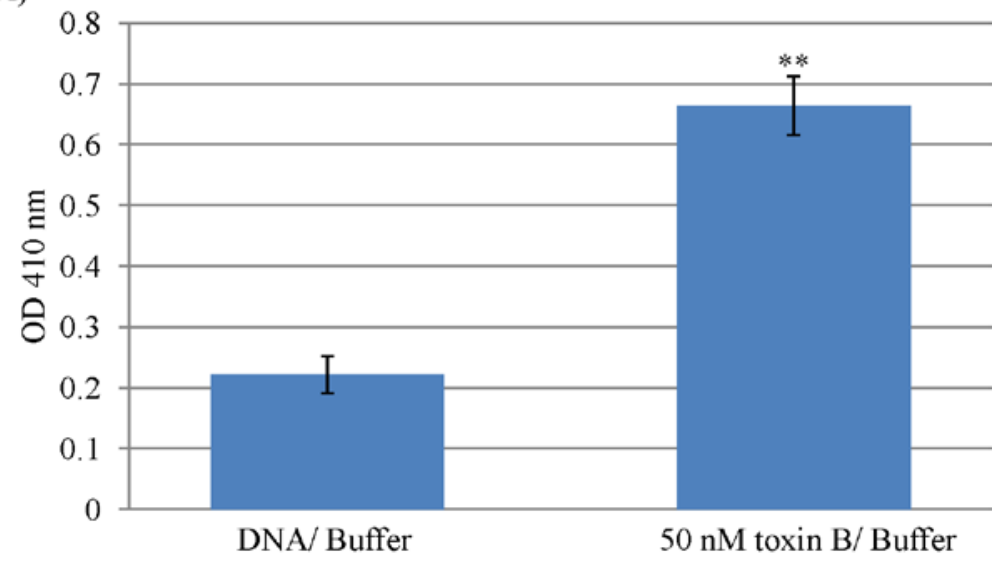

(B)

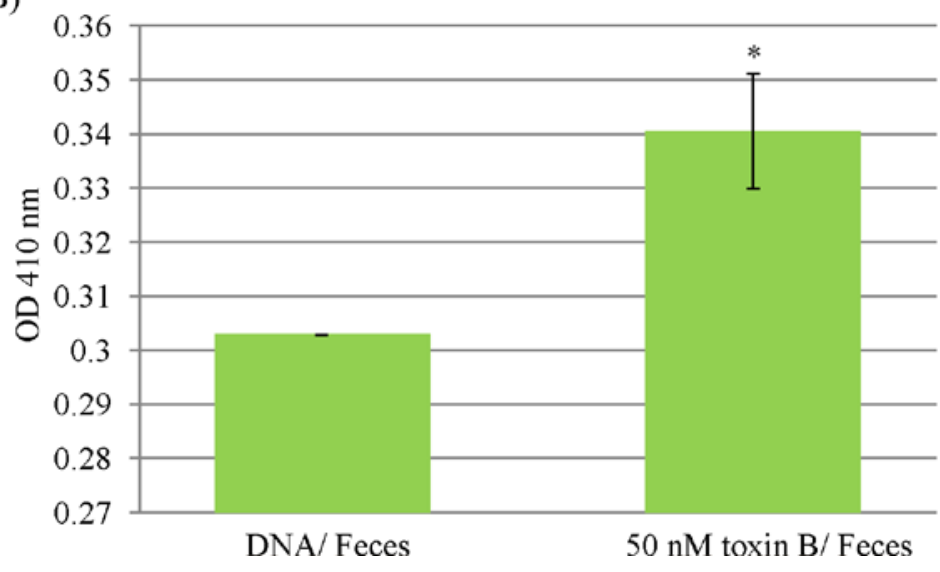

Figure 3.7: R12.69 ssDNA MRE modified ELISA assays of Toxin B. Data from one modified sandwich ELISA assay with absorbance measured at OD $410 \mathrm{~nm}$. Absorbance levels presented are subtracted from background levels of blank wells without immobilized DNA (negative control). Error bars represents 2x standard deviations of 2 sample replicates. (A) Statistical significance levels with respect to DNA in buffer background (without toxin B) of $p<0.01$ are designated by ${ }^{* *}$. (B) Statistical significance levels with respect to fecal background (without toxin $\mathrm{B}$ ) of $p<0.05$ are designated by *. Buffer: $1 \times$ selection buffer; Feces: $1 \mathrm{~g} / 20 \mathrm{~mL} 1 \times$ selection buffer. 
It is to be noted that fecal matter is a complex matrix, which contains multiple macromolecules and ions [52]. Meanwhile, the three dimensional structure of nucleic MREs is highly dependent on the temperature, $\mathrm{pH}$ and ionic strength of the binding condition and these structures are related to their binding abilities [53]. This modified ELISA assay demonstrated the robustness of R12.69 in complex biological matrices. Previous studies have identified ssDNA MREs specific for bacteria toxins and similar ELISA assays were developed for toxin detection [39, 54]. However, both ELISA detections were not tested in clinically relevant samples, which is necessary for translation. Recently, slow off-rate modified binding elements (SOMAmer ${ }^{\mathrm{TM}}$ by SomaLogic, Inc; Boulder, CO) specific for toxins B, A and binary toxin of C. difficile have been identified with subnanomolar affinities [55]. The authors also reported sensitive detection of toxin B at picomolar concentrations in multiple assays, though fecal preparations were not tested in all of the assays. Previous study reported that fecal toxin B levels in patients with CDI ranged from approximately $26 \mathrm{ng} / \mathrm{mL}$ to $25 \mu \mathrm{g} / \mathrm{mL}$ [56]. The current MRE modified ELISA assay can detect toxin B level at $50 \mathrm{nM}(1.35 \mu \mathrm{g} / \mathrm{mL})$, that is within a clinically relevant concentration.

Currently, multiple commercial toxin B ELISA diagnostic kits are available in the market and offer sensitive detection of toxin B at nanograms/ $\mathrm{mL}$ concentrations. It is to be noted that the current clinical usage of the unmodified ssDNA MRE identified in this study is limited due to its lower sensitivity. However, ssDNA MREs have several advantages over antibodies, such as inexpensive chemical synthesis and reusability [57]. The use of the toxin B specific MRE in the modified sandwich ELISA assay therefore has a cost advantage over other currently available diagnostic techniques, and may offer an option for rapid initial screening of CDI. This MRE may also be incorporated into a SPR biosensor for real-time, label-free toxin B detection in biological matrices $[47,49]$. It is also possible to increase the stability of the MRE through chemical 
modification to bases of DNA and may stabilize its secondary structure in complex matrices [58]. Overall, the use of R12.69 demonstrated a proof-of-concept in substituting antibody as the antigen capturing element in clinically relevant samples and may have the potential to augment current and emerging diagnostic techniques of $C$. difficile infections.

\subsection{Conclusions}

This study further validated the stringent in vitro selection variation previously developed by our laboratory. A ssDNA molecular recognition element specific for toxin B has been identified with nanomolar affinity $\left(K_{d}=47.3 \mathrm{nM}\right)$ after twelve rounds of selection. The selected MRE demonstrated low cross-binding activities on negatives targets: bovine serum albumin,

Staphylococcus aureus alpha toxin, Pseudomonas aeruginosa exotoxin A and cholera toxin of Vibrio cholera. A modified sandwich ELISA assay was developed utilizing the selected ssDNA MRE as the antigen capturing element and achieved a sensitive detection of $50 \mathrm{nM}$ of toxin $\mathrm{B}$ in human fecal preparations and demonstrated a proof-of-concept of the diagnostic application of the ssDNA MRE. 


\subsection{References}

1. Bartlett, J.G., et al., Antibiotic-associated pseudomembranous colitis due to toxinproducing clostridia. N Engl J Med, 1978. 298(10): p. 531-4.

2. Shannon-Lowe, J., et al., Prevention and medical management of Clostridium difficile infection. BMJ, 2010. 340: p. c1296.

3. Lucado, J., C. Gould, and A. Elixhauser, Clostridium difficile Infections (CDI) in Hospital stays, 2009. HCUP statistical brief no. 124. 2011, 2009.

4. O'Brien, J.A., et al., The emerging infectious challenge of clostridium difficile-associated disease in Massachusetts hospitals: clinical and economic consequences. Infect Control Hosp Epidemiol, 2007. 28(11): p. 1219-27.

5. Dubberke, E.R., et al., Short- and long-term attributable costs of Clostridium difficileassociated disease in nonsurgical inpatients. Clin Infect Dis, 2008. 46(4): p. 497-504.

6. $\quad$ Redelings, M.D., F. Sorvillo, and L. Mascola, Increase in Clostridium difficile-related mortality rates, United States, 1999-2004. Emerg Infect Dis, 2007. 13(9): p. 1417-9.

7. $\quad$ Kuehne, S.A., et al., The role of toxin A and toxin B in Clostridium difficile infection. Nature, 2010. 467(7316): p. 711-3.

8. Voth, D.E. and J.D. Ballard, Clostridium difficile toxins: mechanism of action and role in disease. Clin Microbiol Rev, 2005. 18(2): p. 247-63.

9. Carroll, K.C. and J.G. Bartlett, Biology of Clostridium difficile: implications for epidemiology and diagnosis. Annu Rev Microbiol, 2011. 65: p. 501-21.

10. Fenner, L., et al., Rapid and reliable diagnostic algorithm for detection of Clostridium difficile. J Clin Microbiol, 2008. 46(1): p. 328-30.

11. Badger, V.O., et al., Clostridium difficile: epidemiology, pathogenesis, management, and prevention of a recalcitrant healthcare-associated pathogen. JPEN J Parenter Enteral Nutr, 2012. 36(6): p. 645-62.

12. Cohen, S.H., et al., Clinical practice guidelines for Clostridium difficile infection in adults: 2010 update by the society for healthcare epidemiology of America (SHEA) and the infectious diseases society of America (IDSA). Infect Control Hosp Epidemiol, 2010. 31(5): p. 431-55.

13. Vanpoucke, H., et al., Evaluation of six commercial assays for the rapid detection of Clostridium difficile toxin and/or antigen in stool specimens. Clin Microbiol Infect, 2001. 7(2): p. 55-64.

14. Carroll, K.C., Tests for the diagnosis of Clostridium difficile infection: the next generation. Anaerobe, 2011. 17(4): p. 170-4.

15. Larson, A.M., A.M. Fung, and F.C. Fang, Evaluation of tcdB real-time PCR in a threestep diagnostic algorithm for detection of toxigenic Clostridium difficile. J Clin Microbiol, 2010. 48(1): p. 124-30.

16. Ticehurst, J.R., et al., Effective detection of toxigenic Clostridium difficile by a two-step algorithm including tests for antigen and cytotoxin. J Clin Microbiol, 2006. 44(3): p. 1145-9.

17. McConnell, E.M., M.R. Holahan, and M.C. DeRosa, Aptamers as promising molecular recognition elements for diagnostics and therapeutics in the central nervous system. Nucleic Acid Ther, 2014. 24(6): p. 388-404.

18. McKeague, M. and M.C. Derosa, Challenges and opportunities for small molecule aptamer development. J Nucleic Acids, 2012. 2012: p. 748913. 
19. So, H.M., et al., Single-walled carbon nanotube biosensors using aptamers as molecular recognition elements. J Am Chem Soc, 2005. 127(34): p. 11906-7.

20. Fodey, T., et al., Developments in the production of biological and synthetic binders for immunoassay and sensor-based detection of small molecules. TrAC Trends in Analytical Chemistry, 2011. 30(2): p. 254-269.

21. Tuerk, C. and L. Gold, Systematic evolution of ligands by exponential enrichment: RNA ligands to bacteriophage T4 DNA polymerase. Science, 1990. 249(4968): p. 505-10.

22. Williams, R.M., et al., In Vitro Selection of a Single-Stranded DNA Molecular Recognition Element Specific for Bromacil. Journal of Nucleic Acids, 2014. 2014: p. 8.

23. Williams, R.M., E. Maher, and L.J. Sooter, In Vitro Selection of a Single-Stranded DNA Molecular Recognition Element for the Pesticide Malathion. Comb Chem High Throughput Screen, 2014.

24. Williams, R., et al., In Vitro Selection of a Single-Stranded DNA Molecular Recognition Element against Atrazine. International Journal of Molecular Sciences, 2014. 15(8): p. 14332-14347.

25. Andersson, L.O., The heterogeneity of bovine serum albumin. Biochim Biophys Acta, 1966. 117(1): p. 115-33.

26. Bhakdi, S. and J. Tranum-Jensen, Alpha-toxin of Staphylococcus aureus. Microbiol Rev, 1991. 55(4): p. 733-51.

27. Lowy, F.D., Staphylococcus aureus infections. N Engl J Med, 1998. 339(8): p. 520-32.

28. Gomez, M.I. and A. Prince, Opportunistic infections in lung disease: Pseudomonas infections in cystic fibrosis. Curr Opin Pharmacol, 2007. 7(3): p. 244-51.

29. Ganguly, N.K. and T. Kaur, Mechanism of action of cholera toxin \& other toxins. Indian J Med Res, 1996. 104: p. 28-37.

30. Deng, R., et al., Target-induced aptamer release strategy based on electrochemical detection of staphylococcal enterotoxin B using GNPs-ZrO2-Chits film. Colloids Surf B Biointerfaces, 2014. 120: p. 1-7.

31. Luo, P., et al., Aptamer biosensor for sensitive detection of toxin A of Clostridium difficile using gold nanoparticles synthesized by Bacillus stearothermophilus. Biosens Bioelectron, 2014. 54: p. 217-21.

32. Temur, E., et al., Attomole sensitivity of staphylococcal enterotoxin B detection using an aptamer-modified surface-enhanced Raman scattering probe. Anal Chem, 2012. 84(24): p. 10600-6.

33. Reinert, D.J., et al., Structural basis for the function of Clostridium difficile toxin B. J Mol Biol, 2005. 351(5): p. 973-81.

34. Wedekind, J.E., et al., Refined crystallographic structure of Pseudomonas aeruginosa exotoxin A and its implications for the molecular mechanism of toxicity. J Mol Biol, 2001. 314(4): p. 823-37.

35. Bujacz, A., Structures of bovine, equine and leporine serum albumin. Acta Crystallogr D Biol Crystallogr, 2012. 68(Pt 10): p. 1278-89.

36. O'Neal, C.J., et al., Structural basis for the activation of cholera toxin by human ARF6GTP. Science, 2005. 309(5737): p. 1093-6.

37. Tanaka, Y., et al., 2-Methyl-2,4-pentanediol induces spontaneous assembly of staphylococcal alpha-hemolysin into heptameric pore structure. Protein Sci, 2011. 20(2): p. 448-56. 
38. Zuker, M., Mfold web server for nucleic acid folding and hybridization prediction. Nucleic Acids Res, 2003. 31(13): p. 3406-15.

39. Choi, J.S., et al., Screening and characterization of high-affinity ssDNA aptamers against anthrax protective antigen. J Biomol Screen, 2011. 16(2): p. 266-71.

40. Connell, G.J., M. Illangesekare, and M. Yarus, Three small ribooligonucleotides with specific arginine sites. Biochemistry, 1993. 32(21): p. 5497-502.

41. Ellington, A.D., M. Khrapov, and C.A. Shaw, The scene of a frozen accident. RNA, 2000. 6(4): p. 485-98.

42. Hall, B., J.R. Hesselberth, and A.D. Ellington, Computational selection of nucleic acid biosensors via a slip structure model. Biosens Bioelectron, 2007. 22(9-10): p. 1939-47.

43. Lozupone, C., et al., Selection of the simplest RNA that binds isoleucine. RNA, 2003. 9(11): p. 1315-22.

44. Majerfeld, I. and M. Yarus, Isoleucine:RNA sites with associated coding sequences. RNA, 1998. 4(4): p. 471-8.

45. Gopinath, S.C., K. Hayashi, and P.K. Kumar, Aptamer that binds to the gD protein of herpes simplex virus 1 and efficiently inhibits viral entry. J Virol, 2012. 86(12): p. 673244.

46. Imaizumi, Y., et al., Efficacy of base-modification on target binding of small molecule DNA aptamers. J Am Chem Soc, 2013. 135(25): p. 9412-9.

47. Ashley, J. and S.F. Li, An aptamer based surface plasmon resonance biosensor for the detection of bovine catalase in milk. Biosens Bioelectron, 2013. 48: p. 126-31.

48. Lee, S.J., et al., ssDNA aptamer-based surface plasmon resonance biosensor for the detection of retinol binding protein 4 for the early diagnosis of type 2 diabetes. Anal Chem, 2008. 80(8): p. 2867-73.

49. Tran, D.T., et al., Selection of aptamers against Ara $h 1$ protein for FO-SPR biosensing of peanut allergens in food matrices. Biosens Bioelectron, 2013. 43: p. 245-51.

50. Cella, L.N., et al., Nano aptasensor for protective antigen toxin of anthrax. Anal Chem, 2010. 82(5): p. 2042-7.

51. Huang, Y., et al., Selection and characterization of DNA aptamers against Staphylococcus aureus enterotoxin C1. Food Chem, 2015. 166: p. 623-9.

52. Cummings, J.H., et al., Changes in fecal composition and colonic function due to cereal fiber. Am J Clin Nutr, 1976. 29(12): p. 1468-73.

53. Patel, D.J., et al., Structure, recognition and adaptive binding in RNA aptamer complexes. J Mol Biol, 1997. 272(5): p. 645-64.

54. Bruno, J.G. and J.L. Kiel, Use of magnetic beads in selection and detection of biotoxin aptamers by electrochemiluminescence and enzymatic methods. Biotechniques, 2002. 32(1): p. 178-80, 182-3.

55. Ochsner, U.A., E. Katilius, and N. Janjic, Detection of Clostridium difficile toxins A, B and binary toxin with slow off-rate modified aptamers. Diagn Microbiol Infect Dis, 2013. 76(3): p. 278-85.

56. Akerlund, T., et al., Correlation of disease severity with fecal toxin levels in patients with Clostridium difficile-associated diarrhea and distribution of PCR ribotypes and toxin yields in vitro of corresponding isolates. J Clin Microbiol, 2006. 44(2): p. 353-8.

57. You, K., et al., Aptamers as functional nucleic acids:In vitro selection and biotechnological applications. Biotechnology and Bioprocess Engineering, 2003. 8(2): p. 64-75. 
58. Wang, R.E., et al., Improving the stability of aptamers by chemical modification. Curr Med Chem, 2011. 18(27): p. 4126-38. 


\section{Chapter 4}

\section{In Vitro Selection of a Single-Stranded DNA Molecular Recognition Element Against S. aureus Alpha Toxin and Sensitive Detection in Human Serum}

This chapter is adapted from the work that has been published in International Journal of Molecular Sciences

Citation: Hong KL, Battistella L, Salva AD, Williams RM, Sooter LJ (2015) In Vitro Selection of a Single-Stranded DNA Molecular Recognition Element Against $S$. aureus Alpha Toxin and Sensitive Detection in Human Serum. International Journal of Molecular Sciences. 16(2): 27942809 


\subsection{Introduction}

Alpha toxin, also known as alpha-hemolysin is a virulence factor secreted by Staphylococcus aureus, a facultative anaerobic Gram positive cocci bacteria [1]. S. aureus can cause a wide variety of infections in both healthy and hospitalized individuals, such as skin/soft tissue infections, bacteremia, pneumonia, and endocarditis [2]. Recent increases in the emergence of methicillin-resistant $S$. aureus (MRSA) in both health care settings and communities have raised global concerns $[3,4]$. It was estimated that there were approximately 300,000 patients in the US hospitalized with S. aureus-induced skin/soft tissues infections in 2007, with an average hospital stay of 4.5 days [5, 6].

Most strains of $S$. aureus produce alpha toxin. It forms pores in target cell membranes, causing leakage of ions and cytolysis. [1]. It has been shown that alpha toxin is involved in cell and tissue damage at infection sites and in inflammatory responses [7]. Antibodies against alpha toxin have been identified in patients with $S$. aureus infection, indicating the systemic involvement of alpha toxin in humans [8]. In addition, the important role of alpha toxin in pathogenesis has been reported in multiple previous studies [9-11].

Due to the problems associated with S. aureus infection, it is important to correctly diagnose these infections in a timely manner. The current diagnosis of $S$. aureus related infections are mostly designed for specific types of infections: echocardiography for patients with suspected S. aureus endocarditis and bacteria culturing from samples collected at sites of infections [12-14]. These methods are slow, non-specific and require multiple tests. Recently, PCR and Western blot/dot ELISA have been investigated to detect the presence of alpha toxincoding genes and alpha toxin to facilitate the diagnosis of $S$. aureus related skin/soft tissue infections $[15,16]$. These methods are sensitive, but require laboratory equipment that may not 
be readily accessible in some hospitals. Other traditional ELISA assays have also been reported for alpha toxin detection $[17,18]$. However, the batch-to-batch variation in antibodies may hinder the standardization of these assays [19].

Single-stranded DNA molecular recognition elements (MRE) are an alternative to antibodies that have the potential to address the current limitations in diagnosing S. aureus infections. MREs can be proteins (antibodies or antibody fragments), small peptides or nucleic acids (aptamers or SOMAmers). They have high affinities and specificities toward the target of interest. The first nucleic acid MRE was described by the Gold laboratory in 1990, and was isolated using the Systematic Evolution of Ligands by Exponential Enrichment (SELEX) [20]. For single-stranded DNA (ssDNA) MREs, the process begins with incubating a large random library of different ssDNA molecules $\left(10^{13}\right.$ to $\left.10^{15}\right)$ with the target of interest. The library is then subject to repeated cycles of partitioning, amplification of bound library molecules, and removal of unbound molecules. One or a few MREs with high affinities and specificities toward the target of interest can be identified at the end of the in vitro selection process.

In this study, a rigorous SELEX scheme previously developed by our laboratory was used to identify a ssDNA MRE that binds to alpha toxin with high affinity and specificity [21-23]. The stringency of this SELEX variant is due to the focus on eliminating library binding to negative targets that are either structurally similar or likely to coexist in the same environment with the target of interest. These negative targets include bovine serum albumin, toxin B of Clostridium difficile, exotoxin A of Pseudomonas aeruginosa and cholera toxin of Vibrio cholerae. In addition, the identified alpha toxin-specific MRE has been utilized in a ssDNA MRE modified sandwich ELISA assay for the detection of the target in human serum samples at nanomolar concentrations. 


\subsection{Material and Methods}

\subsubsection{SELEX for Identification of Alpha Toxin-specific MREs}

The in vitro selection process started from a single-stranded DNA (ssDNA) library consisting of $10^{15}$ different molecules (Figure 4.1). This library was previously designed by our laboratory, termed RMW.N34 [21]. It consisted of two 23 base constant regions for polymerase chain reaction (PCR) amplification flanking by a 34 base random region (synthesized by Eurofins MWG Operon; Huntsville, AL). Twelve rounds of SELEX were carried out to select ssDNA molecules that bound to alpha toxin and those that bound to negative targets were eliminated in the process (Table 4.1, Figure 4.2).

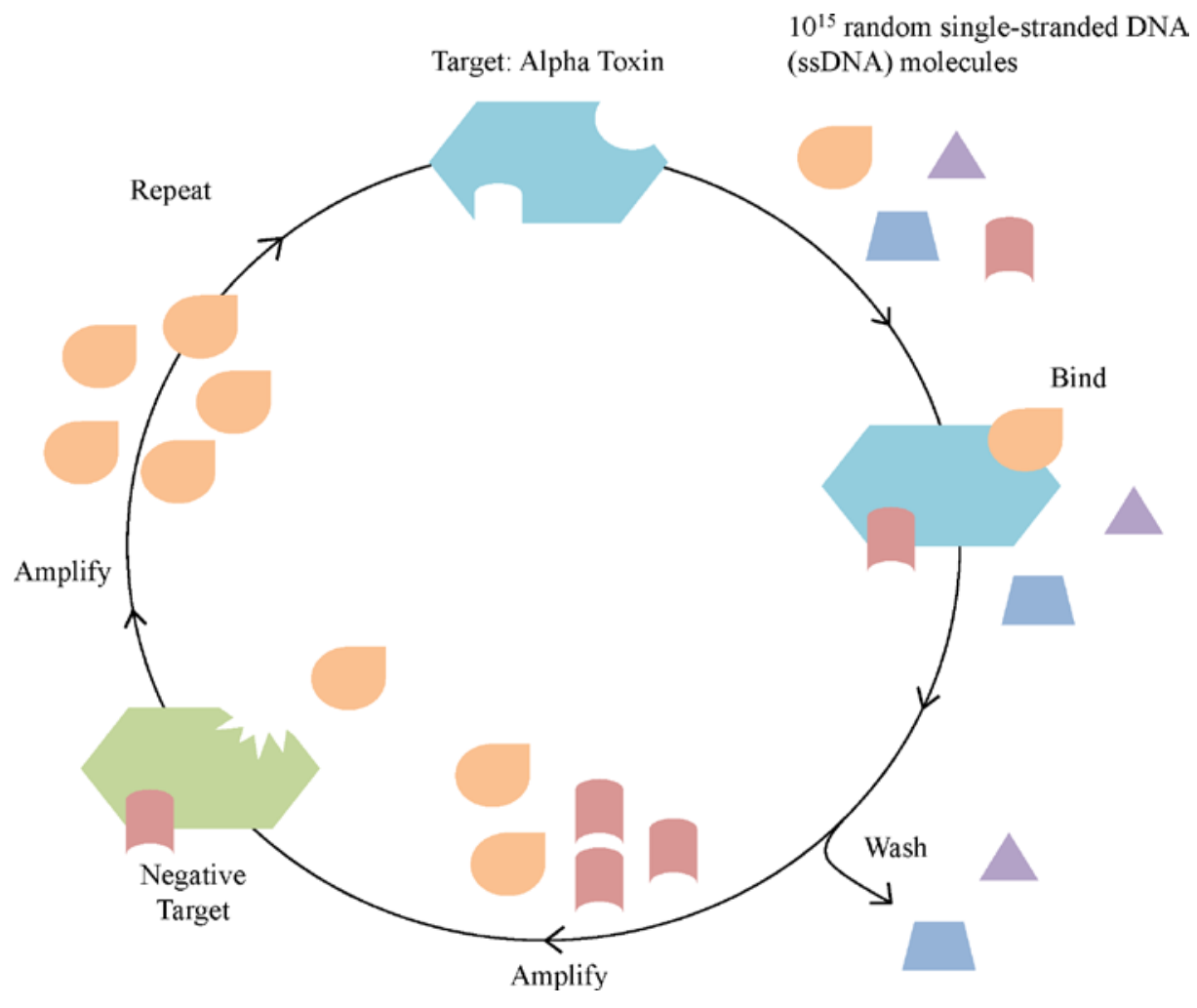

Figure 4.1: Illustration of the Systematic Evolution of Ligands by EXponential enrichment

(SELEX) process. A random library consisting of $10^{15}$ ssDNA molecules (each with 
a different nucleotide sequence, indicated by different shapes) were incubated with the target alpha toxin. Those DNA that bound to the target were amplified and then incubated with negative targets. Those DNA that do not bind to negative targets are amplified and subjected to further rounds of in vitro selection.

Table 4.1: Systematic Evolution of Ligands by EXponential Enrichment (SELEX) scheme for ssDNA molecular recognition element (MRE) identification against alpha toxin.

\begin{tabular}{|c|c|c|c|c|}
\hline Round & Positive Selection $(+)$ & $\begin{array}{l}\text { PCR } \\
\text { Cycles }\end{array}$ & Negative Selection (-) & $\begin{array}{l}\text { PCR } \\
\text { Cycles }\end{array}$ \\
\hline 1 & Immobilized Target (IT) 24 hrs & 9 & - & - \\
\hline 2 & IT $18 \mathrm{hrs}$ & 15 & $\begin{array}{l}\text { BSA Immobilized Negative } \\
\text { Target (INT) } 22 \text { hrs }\end{array}$ & 16 \\
\hline 3 & IT $13 \mathrm{hrs}$ & 13 & BSA INT 26 hrs & 17 \\
\hline 4 & IT 7 hrs & 18 & Exotoxin A INT 22 hrs & 16 \\
\hline 5 & IT $3 \mathrm{hrs}$ & 11 & Exotoxin A INT 26 hrs & 15 \\
\hline 6 & IT 30 min & 17 & BSA INT 24 hrs & 12 \\
\hline 7 & $\begin{array}{l}\text { IT } 5 \mathrm{~min} \text {, Competitive Elution } \\
\text { with } 1 \mathrm{mg} / \mathrm{mL} \text { free alpha toxin, } \\
5 \mathrm{~min}\end{array}$ & 17 & $\begin{array}{l}\text { IT } 5 \mathrm{~min} \text {, Competitive Elution } \\
\text { with } 1 \mathrm{mg} / \mathrm{mL} \text { free BSA, } 5 \text { min }\end{array}$ & 16 \\
\hline 8 & $\begin{array}{l}\text { IT } 5 \mathrm{sec} \text {, Competitive Elution } \\
\text { with } 1 \mathrm{mg} / \mathrm{mL} \text { free alpha toxin, } \\
5 \mathrm{sec}\end{array}$ & 15 & $\begin{array}{l}\text { IT } 5 \text { sec, Competitive Elution } \\
\text { with } 20 \mu \mathrm{g} / \mathrm{mL} \text { free exotoxin a, } 6 \\
\text { hour }\end{array}$ & 13 \\
\hline 9 & $\begin{array}{l}\text { IT } 5 \mathrm{sec} \text {, Competitive Elution } \\
\text { with } 10 \mu \mathrm{g} / \mathrm{mL} \text { free alpha toxin, } \\
5 \mathrm{sec}\end{array}$ & 12 & $\begin{array}{l}\text { IT } 5 \mathrm{sec} \text {, Competitive Elution } \\
\text { with } 20 \mu \mathrm{g} / \mathrm{mL} \text { free cholera } \\
\text { toxin, } 6 \text { hour }\end{array}$ & 13 \\
\hline 10 & $\begin{array}{l}\text { IT } 5 \mathrm{sec} \text {, Competitive Elution } \\
\text { with } 5 \mu \mathrm{g} / \mathrm{mL} \text { free alpha toxin, } \\
5 \mathrm{sec}\end{array}$ & 12 & $\begin{array}{l}\text { IT } 5 \mathrm{sec} \text {, Competitive Elution } \\
\text { with } 20 \mu \mathrm{g} / \mathrm{mL} \text { free toxin B, } 6 \\
\text { hour }\end{array}$ & 13 \\
\hline 11 & $\begin{array}{l}\text { IT } 5 \mathrm{sec} \text {, Competitive Elution } \\
\text { with } 2.5 \mu \mathrm{g} / \mathrm{mL} \text { free alpha } \\
\text { toxin, } 5 \mathrm{sec}\end{array}$ & 19 & $\begin{array}{l}\text { IT } 5 \mathrm{sec} \text {, Competitive Elution } \\
\text { with } 20 \mu \mathrm{g} / \mathrm{mL} \text { free BSA, } 24 \mathrm{hrs}\end{array}$ & 7 \\
\hline 12 & $\begin{array}{l}\text { IT } 5 \mathrm{sec} \text {, Competitive Elution } \\
\text { with } 1 \mu \mathrm{g} / \mathrm{mL} \text { free alpha toxin, } \\
5 \mathrm{sec}\end{array}$ & 10 & - & \\
\hline
\end{tabular}


magnetic beads. BSA is the abbreviation for bovine serum albumin. Times listed are incubation times in hours (hrs), minutes (min) or seconds (sec).

(A)

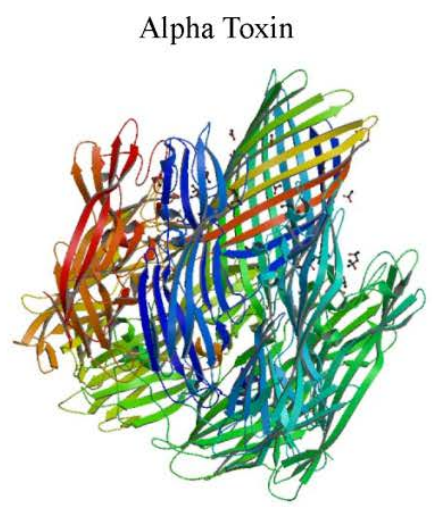

(C)

Bovine Serum Albumin

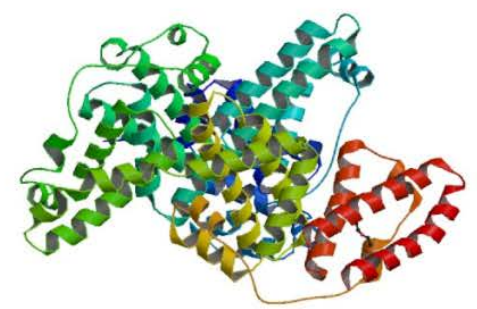

(B)

Exotoxin A

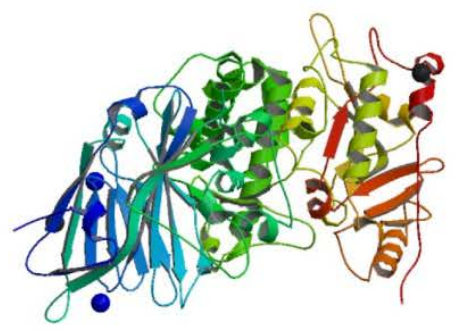

(E) Toxin B

(D)

Cholera Toxin

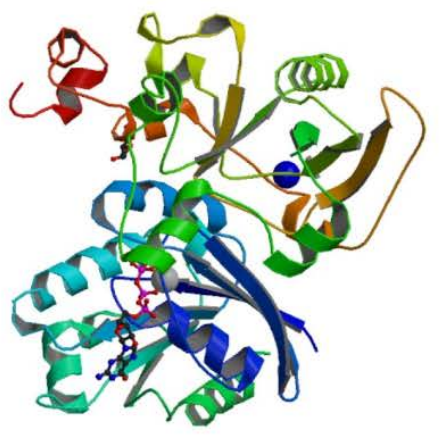

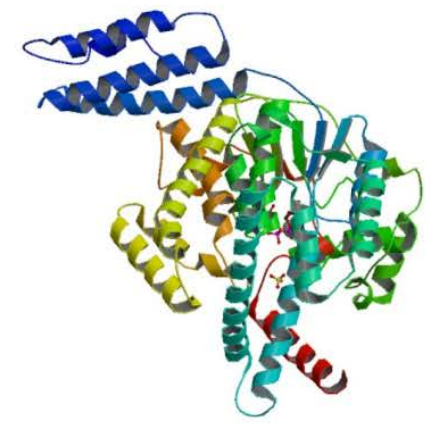

Figure 4.2: Structures of targets used in the SELEX scheme and cross binding assays.

(A) Ribbon structure of the target of interest, alpha toxin (PDB 3ANZ, 33kDa) [24]. (B), (C), (D), (E) Ribbon structure of exotoxin A (PDB 1IKQ, $66 \mathrm{kDa}$ ) [25], bovine serum albumin (PDB 4F5S, $66.5 \mathrm{kDa}$ ) [26], cholera toxin (PDB 2A5D, $84 \mathrm{kDa}$ ) [27], and toxin B (PDB2BVM, $270 \mathrm{kDa}$ ) [28], used in negative rounds of selection and cross binding assays.

Lyophilized alpha toxin (List Biological Laboratories; Campbell, CA) was reconstituted in pure water and conjugated to carboxylic acid-coated magnetic beads (Dynabeads M-270 
Carboxylic Acid, Life Technologies; Grand Island, NY) via a two-step amidation reaction using N-hydroxysulfonyl succinimide (sulfo-NHS) (Pierce; Rockford, IL) and 1-ethyl-3-(3dimethylaminopropyl) (EDC) (Pierce; Rockford, IL). The reaction was performed according to manufacturer's protocol.

For positive rounds of immobilized target selection, the ssDNA library was incubated with $6 \mu \mathrm{L}$ of immobilized target in $200 \mu \mathrm{L}$ of selection buffer (100 mM sodium chloride, $20 \mathrm{mM}$ Tris- $\mathrm{HCl}$, and $2 \mathrm{mM}$ magnesium chloride; $1 \times$ selection buffer, $\mathrm{SB}$ ) at room temperature with rotation. After incubation, the solution was then subjected to magnetic separation. Unbound ssDNA in solution was removed and immobilized target with bound ssDNA was washed three times with $200 \mu \mathrm{L}$ of SB and resuspended in $100 \mu \mathrm{L}$ of SB. This suspension served as template for PCR amplification. The PCR conditions were as follows: bound ssDNA, $400 \mathrm{nM}$ forward and biotinylated reverse RMW.N34 primers (Eurofins MWG Operon; Huntsville, AL) (forward primer sequence: 5' -TGTACCGTCTGAGCGATTCGTAC-3', biotinylated reverse primer sequence: 5' -Biotin-GCACTCCTTAACACTGACTGGCT-3'), $250 \mu \mathrm{M}$ deoxynucleotide triphosphates, $1 \times$ GoTaq Reaction Buffer (Promega; Madison, WI), 3.5 units Taq, and pure water. Thermal cycling conditions were as follows: denature at $95^{\circ} \mathrm{C}$ for 5 minutes, cycle at $95^{\circ}$ $\mathrm{C}$ for 1 minute, $63^{\circ} \mathrm{C}$ for 45 seconds, and $72^{\circ} \mathrm{C}$ for 1 minute; and final extension temperature at $72^{\circ} \mathrm{C}$ for 7 minutes [21-23]. Large-scale $3 \mathrm{~mL}$ PCR was performed after each round of positive and negative selection. This selection process for immobilized alpha toxin target was carried out for Rounds 1-6, each with shortened incubation periods.

Amplified PCR product containing dsDNA was purified with the IBI PCR purification kit (IBI Scientific; Peosta, IA) according to manufacturer's protocol. Single strand separation and ethanol precipitation of the forward strand DNA were performed identically to as previously 
described [21-23]. This procedure was carried out after each round of positive and negative selection.

For negative rounds of selection, BSA and Exotoxin A (List Biological Laboratories; Campbell, CA) were conjugated to carboxylic acid-coated magnetic beads as described above and served as immobilized negative targets. Selection procedures were carried out similarly to positive Rounds 1-6. However, unbound ssDNA in solution served as template for PCR amplification. This procedure was performed for negative Rounds $2-6$.

Free alpha toxin in solution was used to perform competitive elutions beginning in Round 7 positive. The ssDNA library was first incubated with immobilized target as described for positive Rounds 1-6. However, free alpha toxin at a concentration of $1 \mathrm{mg} / \mathrm{mL}$ in SB was used to resuspend the ssDNA bound magnetic beads. The solution containing ssDNA bound to free alpha toxin was retrieved by magnetic separation after 5 minutes of incubation and served as template for PCR amplification. This procedure was carried out for positive Rounds 7-12, each with shorter incubation times and lower free alpha toxin concentrations. Similar competitive elution with free negative targets in SB was performed for negative Rounds 7-11. However, beads were retrieved and resuspended in $100 \mu \mathrm{L}$ of SB and served as template for PCR amplification.

\subsubsection{Cloning and Sequencing of Alpha Toxin-specific MREs}

DNA sequencing was performed following Rounds 3 negative, 6 negative, 9 negative and 12 positive to analyze the enrichment of consensus binding sequences in the ssDNA library. This was performed identically to as previously described [21-23]. A total of thirty to fifty randomly selected sequences were analyzed for each sequenced round. 


\subsubsection{Alpha Toxin-specific MRE SPR Affinity Binding Assays}

One candidate sequence designated as R12.06 from the analyzed round 12 library was chosen for further characterization. Mfold DNA web server was used to predict the secondary structure of R12.06 with parameter settings at the ionic conditions of SB and at $25{ }^{\circ} \mathrm{C}$ [29]. R12.06 was commercially synthesized with a 5' amino-C6 modification for the use of surface plasmon resonance (SPR) affinity binding assays (Eurofins MWG Operon; Huntsville, AL). The 5' end was chosen for the amino modification because in the Mfold predicted secondary structure the 5' end was further away from predicted secondary structures than the 3' end. This provided distance between the immobilization surface and the MRE structure in addition to the C6 linker between the DNA and the amino group. A commercially-purchased CM5 SPR sensor chip (GE Healthcare; Piscataway, NJ) and a sensor chip fabricated in house were used in the assays.

Glass slides (12 mm x $10 \mathrm{~mm}$ ) were coated with a $2 \mathrm{~nm}$ titanium adhesion layer and a 45 nm gold layer using Temescal BJD-2000 system (Edwards Vacuum; Phoenix, AZ) with an Inficon XTC/2 deposition controller (Infincon; East Syracuse, NY). In order to assemble the home-made sensor chip, the gold coated glass slide was first washed with $100 \%$ ethanol under sonication for 5 minutes, then immersed in a self-assembled monolayer solution of $10 \mathrm{mM} 11$ mercaptoundecanoic acid (11-MUA) (Sigma; St. Louis, MO) and $10 \mathrm{mM}$ triethylene glycol mono-11-mercaptoundecylether (PEG3) (Sigma; St. Louis, MO) in a 1 to 5 ratio overnight under argon. After overnight incubation in the solution, the gold chip was rinsed with $100 \%$ ethanol and pure water, blown dry with nitrogen and assembled onto a carrying cartridge. A Biacore X100 (GE Healthcare; Piscataway, NJ) was used for binding assays. 
Both types of sensor chips were first activated by injecting $100 \mathrm{mM}$ N-hydroxysulfonyl succinimide (sulfo-NHS) (Pierce; Rockford, IL) and $400 \quad \mathrm{mM}$ 1-ethyl-3-(3dimethylaminopropyl) (EDC) (Pierce; Rockford, IL) at a 1 to 1 ratio to control and active flow cells at a flow rate of $5 \mu \mathrm{L} / \mathrm{min}$ for ten minutes. Then, 5'amino-C6 modified R12.06 was diluted to $100 \mathrm{nM}$ in immobilization buffer (100 mM sodium chloride, $20 \mathrm{mM}$ potassium phosphate, and $2 \mathrm{mM}$ magnesium chloride, $\mathrm{pH}$ 7.4). This buffer was also used as the running buffer for the DNA immobilization step. A total of $300 \mu \mathrm{L}$ of DNA was injected into active flow cell at a flow rate of $5 \mu \mathrm{L} / \mathrm{min}$, followed by a 10 -minute inactivation step using $1 \mathrm{M}$ ethanolamine- $\mathrm{HCl} \mathrm{pH} 8.5$. Control flow cell without immobilized DNA was also inactivated by 1M ethanolomine-HCL.

The selection buffer was then used as running buffer for single cycle kinetic assays. Alpha toxin at various concentrations $(500 \mathrm{nM}, 750 \mathrm{nM}, 1000 \mathrm{nM}, 1500 \mathrm{nM}, 2000 \mathrm{nM}$ and 2500 $\mathrm{nM}$ ) in SB were injected into both control and active flow cells at a flow rate of $30 \mu \mathrm{L} / \mathrm{min}$ for 180 seconds with a dissociation time of 150 seconds. Binding responses after baseline and control adjustments were analyzed with Biacore X100 evaluation software (GE Healthcare; Piscataway, NJ). A 1:1 binding model was used to determine the equilibrium dissociation constant $\left(\mathrm{K}_{\mathrm{d}}\right)$.

\subsubsection{Alpha Toxin-specific MRE Fluorescence Cross Binding Assays}

Commercially synthesized FAM labeled R12.06 (Eurofins MWG Operon; Huntsville, AL) was used in microplate based fluorescence cross binding assays. The assay was slightly modified from a previous study [30]. Alpha toxin, exotoxin A, toxin B (List Biological Laboratories; Campbell, CA), cholera toxin (List Biological Laboratories; Campbell, CA) and BSA were diluted to $40 \mathrm{nM}$ in $50 \mathrm{mM}$ carbonate/ bicarbonate buffer (pH 9.6). A volume of 90 $\mu \mathrm{L}$ of each diluted toxin, human serum (Sigma; St. Louis, MO) and control blocking buffer (SB 
with $0.05 \%$ Tween-20) were added to individual wells of a 96 well Nunc C8 Lockwell MaxiSorp microplate (Pierce; Rockford, IL). The plate was incubated on a shaker at $4{ }^{\circ} \mathrm{C}$ overnight. After protein coating, all the wells were blocked for 1 hour and washed 3 times with the blocking buffer at room temperature. FAM labeled R12.06 at $100 \mathrm{nM}$ in $90 \mu \mathrm{L}$ of SB was added to control and cross binding target coated wells and incubated for 1 hour at room temperature. Subsequently, unbound FAM-R12.06 was removed and each well was washed 5 times with selection buffer. Lastly, $90 \mu \mathrm{L}$ of SB was added to each well and the plate was measured in a Synergy 2 micoplate reader with excitation at $490 \mathrm{~nm}$ and emission at $520 \mathrm{~nm}$ (Biotek US;

Winooski, VT). Fluorescence measurements were normalized to control and an internal standard of $90 \mu \mathrm{L}$ of $100 \mathrm{nM}$ FAM-R12.06 in SB as previously described [21-23]. All cross binding targets and control well sets were in triplicate. Data was averaged and standard deviation was calculated. A one-tailed student $t$-test was used to determine the statistical significance in difference of the means $(p<0.05)$.

\subsubsection{Alpha Toxin-specific MRE Modified ELISA}

A $100 \mu \mathrm{L}$ sample of commercially synthesized 5' amino-C6 modified R12.06 was diluted to $40 \mathrm{nM}$ in immobilization buffer and added to individual wells of a maleic anhydride activated microplate (Pierce; Rockford, IL) and incubated overnight with shaking at room temperature. Each well was then blocked with blocking buffer (SB, 0.1\% BSA and 0.05\% Tween-20) for 1 hour and washed 3 times with SB/ 0.05\% Tween-20 washing buffer at room temperature. Wells without DNA added served as blank control. SB, human serum, and alpha toxin diluted to 200 $\mathrm{nM}$ in SB and in human serum were added into individual wells and incubated on a shaker for 1 hour at room temperature. SB and human serum served as background control. 
After incubation, all of the contents were aspirated and wells were washed 5 times with the same washing buffer. Then, $100 \mu \mathrm{L}$ of rabbit anti-alpha toxin primary antibody serum (Sigma; St. Louis, MO) at 1 to 500 dilution ratios in washing buffer was added and incubated for 30 minutes with shaking at room temperature. Primary antibody was then aspirated and wells were washed for 3 times. A secondary goat anti-rabbit antibody conjugated to horseradish peroxidase (Pierce; Rockford, IL) at 1 to 500 dilution ratios in washing buffer was added and incubated for 30 minutes with shaking at room temperature. Lastly, all contents were aspirated and washed 5 times as outlined above. ABTS substrate (Pierce; Rockford, IL) was then added to all wells according to manufacturer's instruction. Absorbance at $410 \mathrm{~nm}$ and $650 \mathrm{~nm}$ was measured in a Synergy 2 microplate reader using Gen 51.06 software (Biotek US; Winooski, VT) in two minute increments. Negative controls were wells incubated without antibodies and with only primary antibody. Each set was performed in triplicate. Data was averaged and standard deviations were determined. A two-tailed student t-test was performed to determined statistical differences at $p<0.05$.

\subsection{Results and Discussions}

\subsubsection{Identification of Alpha Toxin-specific MRE}

Twelve rounds of in vitro selection were performed to identify a ssDNA MREs against alpha toxin (Table 4.1). The selection utilized a SELEX scheme previously described by our lab [21]. This scheme was designed to enrich the ssDNA library to bind preferentially to alpha toxin

in solution and to decrease binding to bovine serum albumin (BSA), toxin B, exotoxin A, and cholera toxin. Thirty to fifty random sequences were analyzed for the enrichment of consensus sequence families after every third round of selection (rounds $3,6,9,12$ ) to monitor the diversity of the library. The sequences from round 12 were analyzed for the presence of consensus 
sequences, but were also screened based on their predicted secondary structures and the stability of those structures, as predicted by a Gibbs free energy value. The random region of one sequence, R12.06 from the analyzed Round 12 library appeared to be highly conserved among several sequence families, and therefore it was chosen for further characterization (Table 4.2).

Table 4.2: Sequence families after 12 rounds of SELEX.

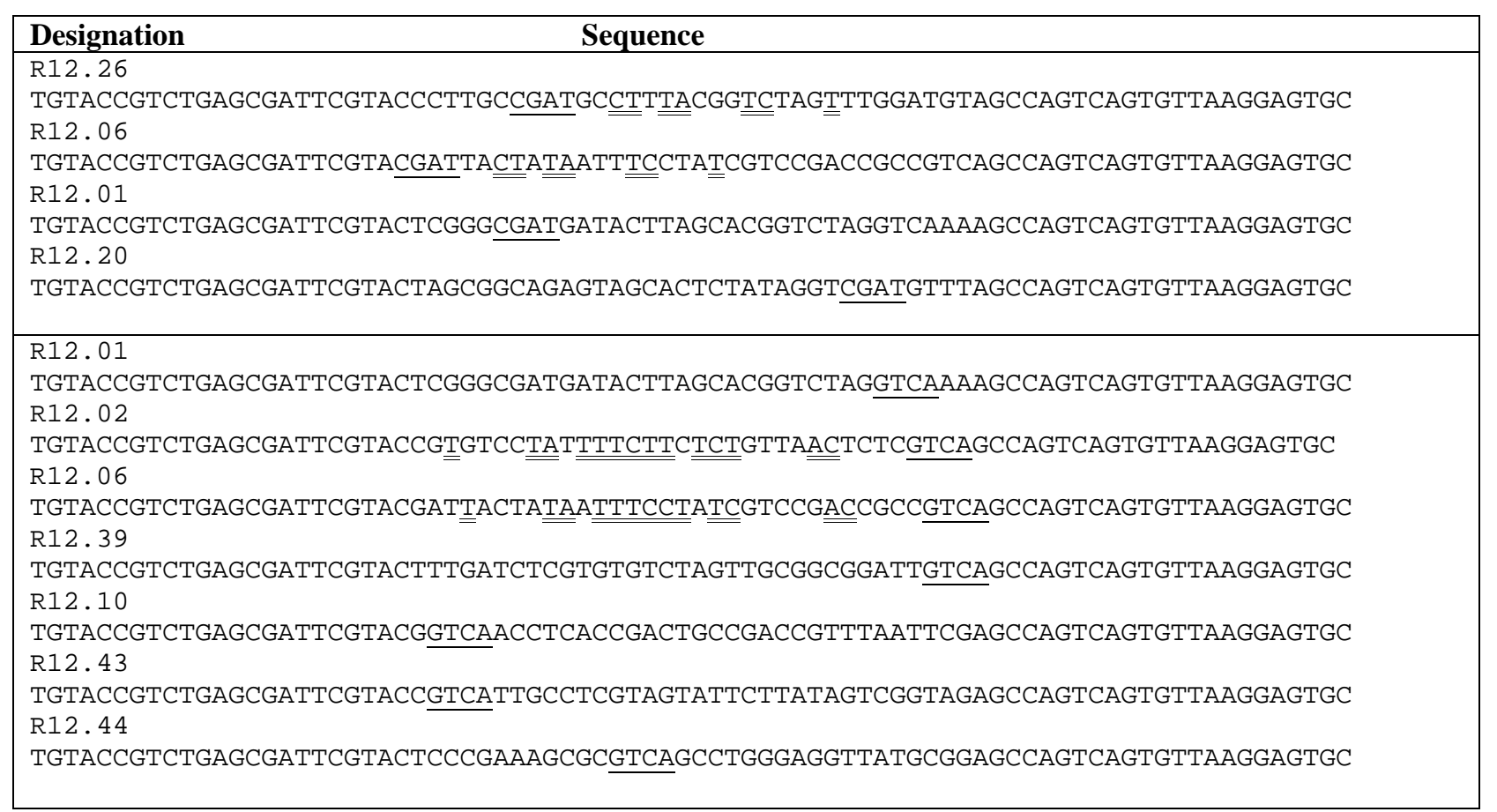

Representative sequence families from Round 12 ssDNA library. Families are separated by difference cells of the table with according to common their consensus sequences (underline)s and sequence homologies (double-underlined).

The Mfold predicted secondary structure showed a long stem-loop structure comprised of the random region of the MRE and with a Gibbs free energy value of $-8.85 \mathrm{kcal} / \mathrm{mol}$ (Figure 4.3). The entire random region of R12.06 participated in the formation of the long stem-loop secondary structure according to the Mfold prediction. The random region of R12.06 also shares 
approximately $30 \%$ and $50 \%$ identity with the random regions of R12.26 and R12.02 respectively.

(A) TGTACCGTCTGAGCGATTCGTACGATTACTATAATTTCCTATCGTCCGACCGCCGTCAGCCAGTCAGTGTTAAGGAGTGC

(B)

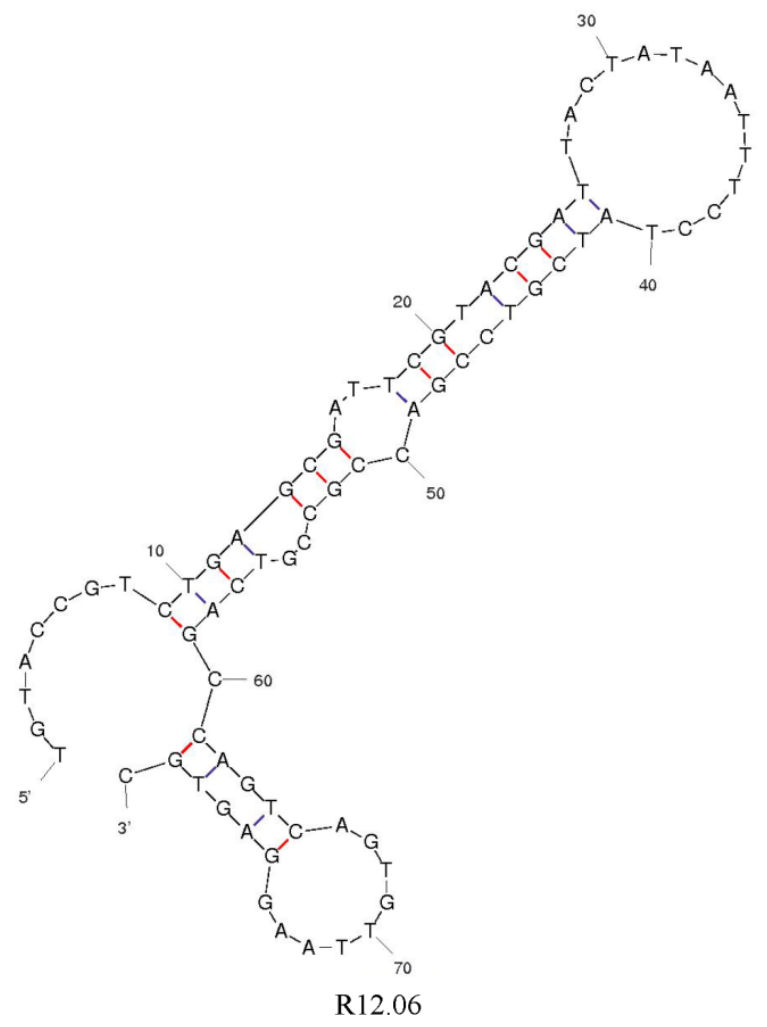

Figure 4.3: Sequence and secondary structure of R12.06 ssDNA MRE. (A) ssDNA sequence of alpha toxin MRE R12.06; (B) Mfold prediction of R12.06 secondary structure [29]. 


\subsubsection{Affinity and Specificity of Alpha Toxin-specific MRE}

Surface plasmon resonance single cycle kinetics assays were used to determine the affinity of R12.06 for alpha toxin. The average equilibrium dissociation constant $\left(\mathrm{K}_{\mathrm{d}}\right)$ was $93.7 \pm$ $7.0 \mathrm{nM}$ (Table 4.3).

Table 4.3: SPR affinity data of R12.06 ssDNA MRE.

\begin{tabular}{lll}
\hline & $\mathbf{K}_{\mathbf{d}}(\mathbf{n M})$ & $\chi^{2}(\mathbf{R U})^{2}$ \\
\hline Assay 1 & 102 & 0.493 \\
Assay 2 & 88.7 & 0.691 \\
Assay 3 & 90.7 & 0.164 \\
Averaged & $93.7 \pm 7.0$ & - \\
\hline
\end{tabular}

The averaged equilibrium dissociation constant is given with standard deviation from three assays. The $\chi^{2}$ described the closeness of fit between the experimental and fitted curve. RU represents the response unit generated by the SPR instrument.

Single cycle kinetics has previously been used to determine the binding affinities of nucleic acid MREs [31, 32]. This assay is typically used for sensor surfaces that are difficult to regenerate and cannot therefore undergo classical multi-cycle kinetic analysis. Single cycle kinetics has also been shown to provide equally valid results as multi-cycle assays [33, 34]. Ligand (ssDNA MRE) immobilization strategies described in this work differ from many previous studies [31, 35-37]. Here, covalent linkage of 5'-amino modified ssDNA MRE was performed instead of the more typical biotin-streptavidin capturing. At neutral to slightly basic running buffer, the electrical repulsion between the negatively charged DNA and sensor chip surface leads to relatively lower level of ligand immobilization by covalent attachment. Both sensor chips produced in house and commercial CM5 sensor chips were utilized in the assays. A different concentration range (25nM to $500 \mathrm{nM}$ ) of alpha toxin was also tested and yielded a 
comparable result $\left(\mathrm{K}_{\mathrm{d}}=90.7 \mathrm{nM}\right)$, and thus confirming the validity of the determined equilibrium dissociation constant. The $\mathrm{K}_{\mathrm{d}}$ of R12.06 is comparable to other previously reported $K_{d}$ values of MREs targeting bacterial toxins [30, 38, 39]. This further validates the SELEX variation previously developed by our laboratory [21-23].

A fluorescent plate-based assay was used to determine the cross binding activity of R12.06. This assay was slightly modified from that which is previously described by using a different washing buffer [30]. The data is presented relative to binding between R12.06 and alpha toxin as has been previously described [21, 22]. The ssDNA MRE exhibits significant binding preference to alpha toxin over all negative targets $(p<0.05)$ (Table 4.4).

Table 4.4: Cross-reactivity data of R12.06 ssDNA MRE.

\begin{tabular}{lllll}
\hline Target & $\begin{array}{l}\text { Normalized } \\
\text { Average } \\
\text { Fluorescence }\end{array}$ & $\begin{array}{l}\text { Standard } \\
\text { Deviation }\end{array}$ & $\boldsymbol{p}$-Value & Selective Ratio \\
\hline Alpha Toxin & 0.047 & 0.007 & - & - \\
Cholera Toxin & 0.031 & 0.009 & 0.003 & 1.5 \\
Exotoxin A & 0.031 & 0.002 & 0.004 & 1.5 \\
Toxin B & 0.009 & 0.002 & 0.001 & 5.0 \\
Bovine Serum & 0.026 & 0.001 & 0.027 & 1.8 \\
Albumin & & 0.003 & 0.017 & 1.7 \\
\hline Human Serum & 0.028 & & & \\
\hline
\end{tabular}

The binding of R12.06 to alpha toxin is 1.5 times greater than cholera toxin and exotoxin A ( $p=0.003$ and $p=0.004$ respectively), 5.0 times greater than toxin $\mathrm{B}(\mathrm{p}=0.0005)$, and 1.8 times greater than BSA $(p=0.03)$. It is important to note that components of human serum were not included in the negative selection scheme, but R12.06 still shows 1.7 times greater selectivity over human serum $(p=0.02)$. This selectivity is important for downstream application development. An interesting phenomenon observed in this study is that the binding selectivity over toxin $\mathrm{B}(270 \mathrm{kDa})$ is more than triple that of cholera toxin $(84 \mathrm{kDa})$. However, both toxins 
were only introduced once in the negative selection scheme. A similar phenomenon was also observed in another study from the Sooter laboratory that investigated the binding selectivity of a C. difficile toxin B specific ssDNA MRE over other toxins, in which the toxin B MRE is two times more selective of alpha toxin (33 kDa) over cholera toxin. Based upon these two observations, it is likely that the binding selectivity of the ssDNA library is enriched early on in the selection process and the target molecular weight and crystal structure may play a role in the selectivity of MREs. The overall low cross binding activities in all tested negative targets further validates the stringency of our selection process [21-23].

\subsubsection{Diagnostic Application of Alpha Toxins-specific MRE}

The high affinity and specificity of the alpha toxin specific ssDNA MRE allowed the investigation of its potential application as a diagnostic tool. A modified ELISA using R12.06 as the toxin-capturing element was developed (Figure 4.4). 


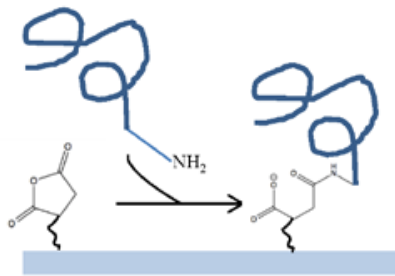

5' amino-MRE immobilized on maleic anhydride activated microplate well

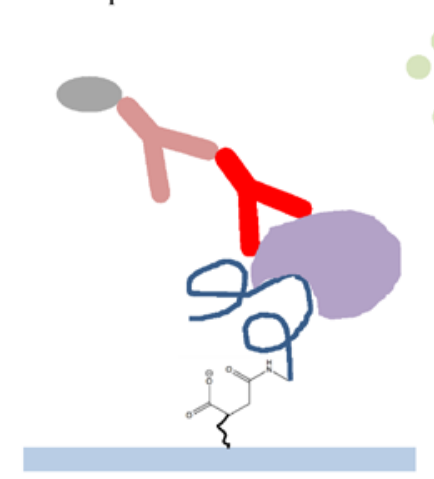

Add secondary antibody conjugated to horseradish peroxidase (HRP)

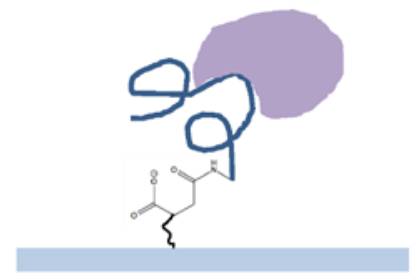

Add Alpha Toxin (not to scale)

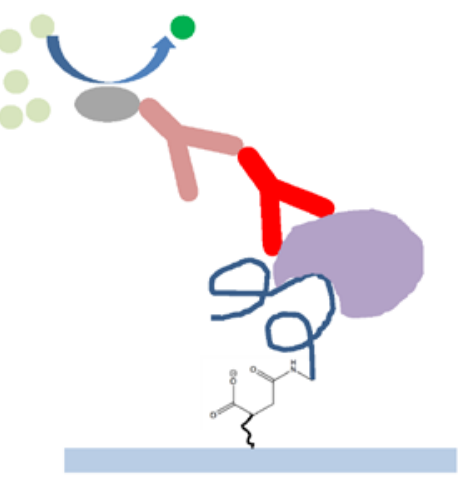

Add ABTS, substrate of (HRP)

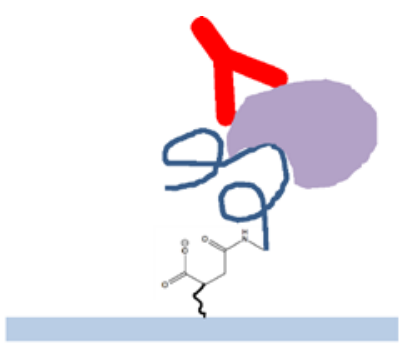

Add primary anti-Alpha Toxin antibody

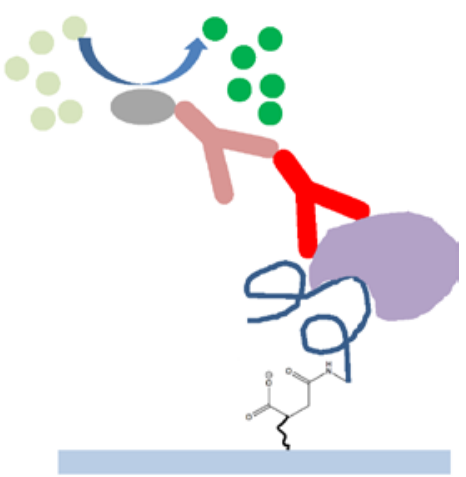

Signal is amplified and monitored over time

Figure 4.4: Illustration of the ssDNA MRE modified ELISA assay. The ssDNA MRE was used as the capturing element in the sandwich ELISA assay.

Reproducible and statistically significant detection of $200 \mathrm{nM}$ alpha toxin spiked in human serum samples were achieved compared to control in multiple assays ( $p<0.01$ to $p<$ 0.001) (Figure 4.5). The significant differences were first detected 20 minutes after the addition of horse radish peroxidase substrates. It is important to note that the average half-life of ssDNA MREs in serum is about one hour due to the presence of exonucleases [40]. The R12.06 MRE demonstrated its robustness in serum without any base modifications. The three dimensional structure of nucleic acid MREs are known to be influenced by temperature, $\mathrm{pH}$ and ionic strength of the binding conditions [41]. The R12.06 MRE was able to retain a level of affinity and specificity in undiluted human serum, which is a complex biological matrix with serum proteins, 
lipids and varied ionic concentrations [42]. The assay completion time from the addition of alpha toxin to positive result was less than 4 hours. This demonstrates the potential of R12.06 as a clinical diagnostic tool.
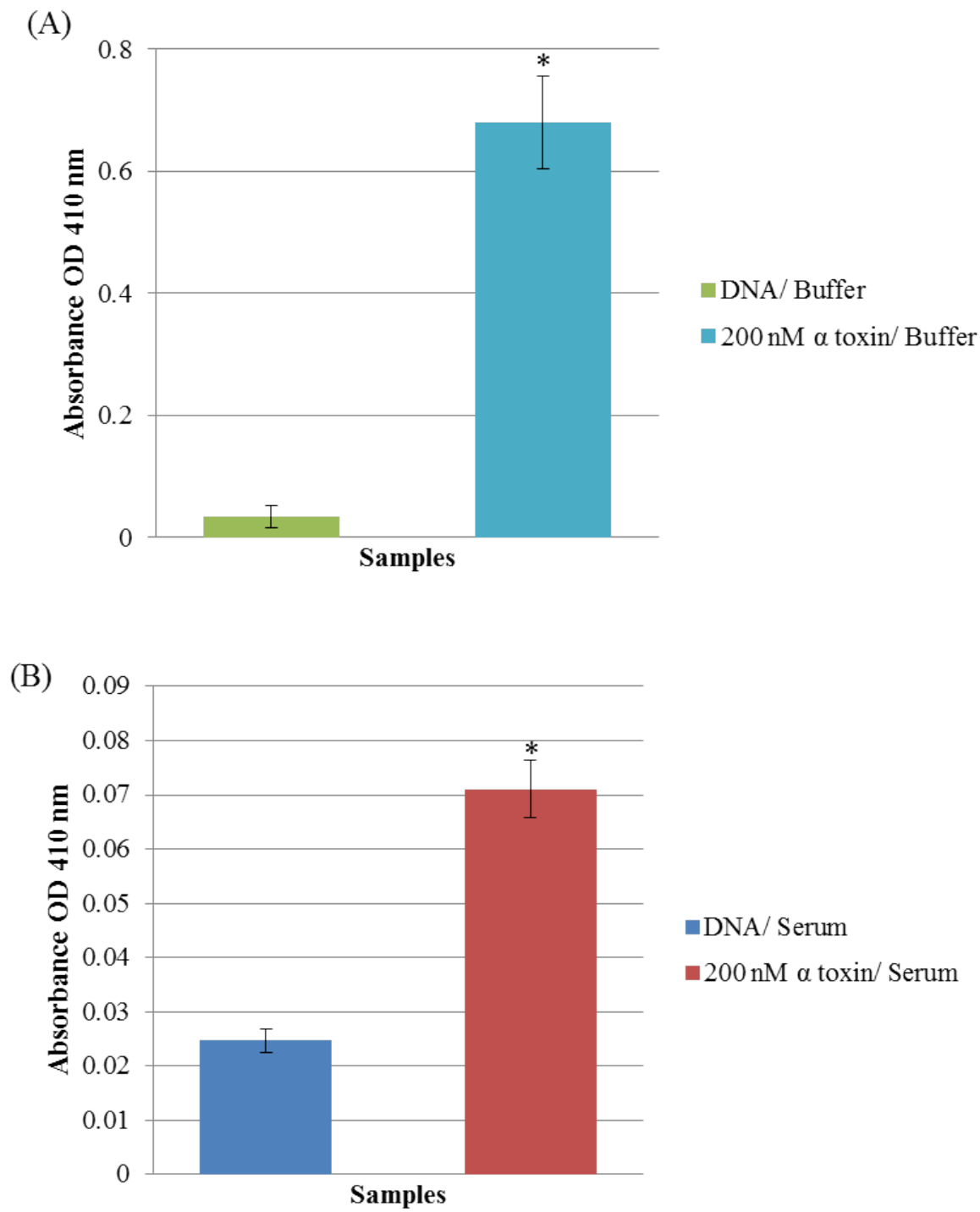

Figure 4.5: Detection of alpha toxin in modified ELISA assay. Data represent one modified sandwich ELISA with absorbance measured at $410 \mathrm{~nm}$. Absorbance levels are subtracted from background levels of blank wells without immobilized DNA. (A) Statistical significance levels with respect to DNA with buffer background of $p<0.001$ are 
designated by *. (B) Statistical significance levels with respect to human serum background of $p<0.001$ are designated by *. Buffer: $1 \times$ selection buffer. Error bars are representative of $+/-1 \times$ standard deviations.

A single-stranded DNA MRE was previously incorporated into a system for target detection in binding buffer-diluted human serum [43]. Similar ssDNA MRE based ELISA assays have also been reported in previous studies for the detection of bacterial toxin targets in binding buffer [30, 44]. In comparison, the assay in this study demonstrates a level of superiority by detecting target molecules in minimally manipulated and clinically relevant samples. Traditional antibody-based ELISA assays for the detection of alpha toxin have been previously reported with high sensitivity in bacterial culture media (LOD of $1 \mathrm{ng} / \mathrm{mL}$ ) [17, 18]. In these experiments 200 $\mathrm{nM}$, or $6.6 \mu \mathrm{g} / \mathrm{mL}$, alpha toxin in human serum was detected. While highly reproducible, the signal is small enough to be near the limit of detection for the system described. This level is within the range of clinical relevance, as previous work has shown levels to be as high as $83 \mu \mathrm{g} / \mathrm{mL}$ [45]. The sensitivity of the assay may be improved by making the ssDNA MRE more resistant to exonucleases. This stability limitation may be resolved by base modifications [46]. In contrast to antibodies, ssDNA MREs also have several advantages, such as thermostability, reversible denaturation and inexpensive chemical synthesis [47]. It is to be noted that another ssDNA MRE targeting alpha toxin has been reported recently [48]. The authors investigated the potential therapeutic application of their selected MRE, however, no binding affinity and specificity data were reported in the study. It is unknown if R12.06 will demonstrate neutralizing effect on alpha toxin. Based upon the determined high affinity and specificity of R12.06, its translational value may not be limited to diagnostic detection and may warrant future studies. In sum, the ability of 
R12.06 to detect alpha toxin in undiluted human serum samples has been demonstrated, which has the potential to augment current and future diagnostic methods for $S$. aureus related infections.

\subsection{Conclusions}

This study utilized a robust SELEX methodology to identify a molecular recognition element specific for alpha toxin of Staphylococcus aureus with high affinity and specificity. The MRE binds with a nanomolar equilibrium dissociation constant $\left(\mathrm{K}_{\mathrm{d}}\right)$ of $93.7 \pm 7.0 \mathrm{nM}$ and is selective for alpha toxin over all bacteria toxins used in the negative selection scheme and in human serum. In addition, a proof-of-concept diagnostic sandwich ELISA utilizing the MRE as the toxin capturing element has been developed and successfully demonstrated target detection at $200 \mathrm{nM}$ in undiluted human serum samples. The results further validate our SELEX process and showed the potential of applying ssDNA MREs in diagnostic applications. 


\subsection{References}

1. Bhakdi, S. and J. Tranum-Jensen, Alpha-toxin of Staphylococcus aureus. Microbiol Rev, 1991. 55(4): p. 733-51.

2. $\quad$ Lowy, F.D., Staphylococcus aureus infections. N Engl J Med, 1998. 339(8): p. 520-32.

3. Mediavilla, J.R., et al., Methicillin-susceptible Staphylococcus aureus ST398, New York and New Jersey, USA. Emerg Infect Dis, 2012. 18(4): p. 700-2.

4. Vandenesch, F., et al., Community-acquired methicillin-resistant Staphylococcus aureus carrying Panton-Valentine leukocidin genes: worldwide emergence. Emerg Infect Dis, 2003. 9(8): p. 978-84.

5. Moet, G.J., et al., Contemporary causes of skin and soft tissue infections in North America, Latin America, and Europe: report from the SENTRY Antimicrobial Surveillance Program (1998-2004). Diagn Microbiol Infect Dis, 2007. 57(1): p. 7-13.

6. Stephens, J.M., et al., Economic burden of inpatient and outpatient antibiotic treatment for methicillin-resistant Staphylococcus aureus complicated skin and soft-tissue infections: a comparison of linezolid, vancomycin, and daptomycin. Clinicoecon Outcomes Res, 2013. 5: p. 447-57.

7. Vandenesch, F., G. Lina, and T. Henry, Staphylococcus aureus hemolysins, bi-component leukocidins, and cytolytic peptides: a redundant arsenal of membrane-damaging virulence factors? Front Cell Infect Microbiol, 2012. 2: p. 12.

8. Jacobsson, G., et al., Antibody responses in patients with invasive Staphylococcus aureus infections. Eur J Clin Microbiol Infect Dis, 2010. 29(6): p. 715-25.

9. Bubeck Wardenburg, J., R.J. Patel, and O. Schneewind, Surface proteins and exotoxins are required for the pathogenesis of Staphylococcus aureus pneumonia. Infect Immun, 2007. 75(2): p. 1040-4.

10. Callegan, M.C., et al., Corneal virulence of Staphylococcus aureus: roles of alpha-toxin and protein A in pathogenesis. Infect Immun, 1994. 62(6): p. 2478-82.

11. Kennedy, A.D., et al., Targeting of alpha-hemolysin by active or passive immunization decreases severity of USA300 skin infection in a mouse model. J Infect Dis, 2010. 202(7): p. 1050-8.

12. Duckworth, G.J., Diagnosis and management of methicillin resistant Staphylococcus aureus infection. BMJ, 1993. 307(6911): p. 1049-52.

13. Mitchell, D.H. and B.P. Howden, Diagnosis and management of Staphylococcus aureus bacteraemia. Intern Med J, 2005. 35 Suppl 2: p. S17-24.

14. Roberts, S. and S. Chambers, Diagnosis and management of Staphylococcus aureus infections of the skin and soft tissue. Intern Med J, 2005. 35 Suppl 2: p. S97-105.

15. Ramakrishna, U.S., et al., Taguchi optimization of duplex PCR for simultaneous identification of Staphylococcus aureus and Clostridium perfringens alpha toxins. FEMS Microbiol Lett, 2013. 340(2): p. 93-100.

16. Uppalapati, S.R., et al., Generation and characterization of an inter-generic bivalent alpha domain fusion protein alphaCS from Clostridium perfringens and Staphylococcus aureus for concurrent diagnosis and therapeutic applications. J Appl Microbiol, 2012. 113(2): p. 448-58.

17. Reddy, P.K., et al., Evaluation of IgY capture ELISA for sensitive detection of alpha hemolysin of Staphylococcus aureus without staphylococcal protein A interference. J Immunol Methods, 2013. 391(1-2): p. 31-8. 
18. Surujballi, O.P. and H.B. Fackrell, Enzyme-linked immunosorbent assay for detection of Staphylococcus aureus alpha-toxin. J Clin Microbiol, 1984. 19(3): p. 394-8.

19. Bordeaux, J., et al., Antibody validation. Biotechniques, 2010. 48(3): p. 197-209.

20. Tuerk, C. and L. Gold, Systematic evolution of ligands by exponential enrichment: RNA ligands to bacteriophage T4 DNA polymerase. Science, 1990. 249(4968): p. 505-10.

21. Williams, R., et al., In Vitro Selection of a Single-Stranded DNA Molecular Recognition Element against Atrazine. Int J Mol Sci, 2014. 15(8): p. 14332-14347.

22. Williams, R.M., et al., In Vitro Selection of a Single-Stranded DNA Molecular Recognition Element Specific for Bromacil. J Nucleic Acids, 2014. 2014: p. 8.

23. Williams, R.M., E. Maher, and L.J. Sooter, In Vitro Selection of a Single-Stranded DNA Molecular Recognition Element for the Pesticide Malathion. Comb Chem High Throughput Screen, 2014.

24. Tanaka, Y., et al., 2-Methyl-2,4-pentanediol induces spontaneous assembly of staphylococcal alpha-hemolysin into heptameric pore structure. Protein Sci, 2011. 20(2): p. 448-56.

25. Wedekind, J.E., et al., Refined crystallographic structure of Pseudomonas aeruginosa exotoxin A and its implications for the molecular mechanism of toxicity. J Mol Biol, 2001. 314(4): p. 823-37.

26. Bujacz, A., Structures of bovine, equine and leporine serum albumin. Acta Crystallogr D Biol Crystallogr, 2012. 68(Pt 10): p. 1278-89.

27. O'Neal, C.J., et al., Structural basis for the activation of cholera toxin by human ARF6GTP. Science, 2005. 309(5737): p. 1093-6.

28. Reinert, D.J., et al., Structural basis for the function of Clostridium difficile toxin B. J Mol Biol, 2005. 351(5): p. 973-81.

29. Zuker, M., Mfold web server for nucleic acid folding and hybridization prediction. Nucleic Acids Res, 2003. 31(13): p. 3406-15.

30. Choi, J.S., et al., Screening and characterization of high-affinity ssDNA aptamers against anthrax protective antigen. J Biomol Screen, 2011. 16(2): p. 266-71.

31. Gopinath, S.C., K. Hayashi, and P.K. Kumar, Aptamer that binds to the gD protein of herpes simplex virus 1 and efficiently inhibits viral entry. J Virol, 2012. 86(12): p. 673244.

32. Imaizumi, Y., et al., Efficacy of base-modification on target binding of small molecule DNA aptamers. J Am Chem Soc, 2013. 135(25): p. 9412-9.

33. Karlsson, R., et al., Analyzing a kinetic titration series using affinity biosensors. Anal Biochem, 2006. 349(1): p. 136-47.

34. Suenaga, E., H. Mizuno, and K.K. Penmetcha, Monitoring influenza hemagglutinin and glycan interactions using surface plasmon resonance. Biosens Bioelectron, 2012. 32(1): p. 195-201.

35. Ashley, J. and S.F. Li, An aptamer based surface plasmon resonance biosensor for the detection of bovine catalase in milk. Biosens Bioelectron, 2013. 48: p. 126-31.

36. Lee, S.J., et al., ssDNA aptamer-based surface plasmon resonance biosensor for the detection of retinol binding protein 4 for the early diagnosis of type 2 diabetes. Anal Chem, 2008. 80(8): p. 2867-73.

37. Tran, D.T., et al., Selection of aptamers against Ara $h 1$ protein for FO-SPR biosensing of peanut allergens in food matrices. Biosens Bioelectron, 2013. 43: p. 245-51. 
38. Cella, L.N., et al., Nano aptasensor for protective antigen toxin of anthrax. Anal Chem, 2010. 82(5): p. 2042-7.

39. Huang, Y., et al., Selection and characterization of DNA aptamers against Staphylococcus aureus enterotoxin C1. Food Chem, 2015. 166: p. 623-9.

40. White, R.R., B.A. Sullenger, and C.P. Rusconi, Developing aptamers into therapeutics. J Clin Invest, 2000. 106(8): p. 929-34.

41. Patel, D.J., et al., Structure, recognition and adaptive binding in RNA aptamer complexes. J Mol Biol, 1997. 272(5): p. 645-64.

42. Dayton, S., et al., Composition of lipids in human serum and adipose tissue during prolonged feeding of a diet high in unsaturated fat. J Lipid Res, 1966. 7(1): p. 103-11.

43. Park, J.W., et al., Rapid and sensitive detection of Nampt (PBEF/visfatin) in human serum using an ssDNA aptamer-based capacitive biosensor. Biosens Bioelectron, 2012. 38(1): p. 233-8.

44. Bruno, J.G. and J.L. Kiel, Use of magnetic beads in selection and detection of biotoxin aptamers by electrochemiluminescence and enzymatic methods. Biotechniques, 2002. 32(1): p. 178-80, 182-3.

45. Mairpady Shambat, S., et al., Levels of alpha-toxin correlate with distinct phenotypic response profiles of blood mononuclear cells and with agr background of communityassociated Staphylococcus aureus isolates. PLoS One, 2014. 9(8): p. e106107.

46. Wang, R.E., et al., Improving the stability of aptamers by chemical modification. Curr Med Chem, 2011. 18(27): p. 4126-38.

47. You, K., et al., Aptamers as functional nucleic acids:In vitro selection and biotechnological applications. Biotechnology and Bioprocess Engineering, 2003. 8(2): p. 64-75.

48. Vivekananda, J., C. Salgado, and N.J. Millenbaugh, DNA aptamers as a novel approach to neutralize Staphylococcus aureus alpha-toxin. Biochem Biophys Res Commun, 2014. 444(3): p. 433-8. 


\section{Chapter 5}

\section{Overall Conclusions and Future Studies}




\subsection{Summary}

In summary, the work that has been presented herein demonstrated several important findings in the field of ssDNA MRE isolation and application.

Firstly, three ssDNA MREs with high affinities and specificities have been identified with the Decoy-SELEX method. These properties of the selected ssDNA MREs are important for downstream applications. This work is novel in that the first ssDNA MREs were isolated against Pseudomonas aeruginosa exotoxin A and Clostridium difficile toxin B. It is also novel that these MREs were used in biosensing applications where the toxins were detected in biologically relevant samples. Although a previous ssDNA MRE was isolated against Staphylococcus aureus alpha toxin [1], the alpha toxin-specific ssDNA MRE isolated in this work was the first to apply it to a sensing application.

Secondly, the method developed for immobilizing amino modified ssDNA MREs on customized gold surface in Chapter 2 has an important role in the fabrication of a stable sensory surface. This setup is readily translatable into the final design of the recognition component of a biosensor.

Thirdly, the developed modified ELISA assays are applicable in clinical diagnostic laboratories. Bacterial toxin targets were detected in clinically relevant samples, and at clinically relevant concentrations. This confirmed the selected unmodified ssDNA MREs were robust and specific in the targets' native environments. There were minimal sample manipulations in the steps of the modified ELISA assay, which is desirable and practical for real-world situations.

Lastly, this work established the foundations for future studies in the application of ssDNA MREs. These foundations and future studies are briefly described in the following sections. 


\subsection{Future Studies}

The work described in Chapter 2 through 4 established the foundation in the biosensing application of ssDNA MRE. Although the presented detection assays are a proof-of-concept at the current stage, this work can be further developed into biosensors that are potentially more sensitive and sophisticated. The ultimate design for an ideal ssDNA MRE based biosensor will be in the form of a point-of-care system. 


\section{Appendix}

\section{In Vitro Selection of a Single-Stranded DNA Molecular Recognition Element Against Pesticide Fipronil}




\section{A.1 Introduction}

Fipronil is a widely used phenlpyrazole insecticide in the United States since it was first introduced in the late-1990s [1]. Fipronil inhibits gamma-aminobutyric acid (GABA) gated chloride channels and causes continuous excitation of the central nervous system [2]. Due to the increasing resistance to organophosphate pesticide, fipronil is often used as an alternative in many settings, this includes residential, commercial, and agricultural [3]. From 2000 to 2005, the sales of fipronil in California have increased by 10-fold [4]. Report indicates that fipronil currently accounts for approximately $10 \%$ of the global pesticide market [5]. Its widespread use has led to a rapid increase in environmental exposure to fipronil.

Due the popular use of fipronil, it has become a widespread environmental contaminant. During 2002-2011, fipronil was detected in urban streams up to 63\% of the time, and about 15 to $20 \%$ of the time in agricultural, and mixed land streams in the United States [3]. Additionally, measured concentrations of fipronil exceed the aquatic-life benchmark in $70 \%$ of urban streams and more than $20 \%$ of agricultural, and mixed land streams in the mentioned time period [3]. Fipronil detected in surface water had levels up to $6.4 \mu \mathrm{g} / \mathrm{L}$ in selected area [6]. It has been shown to contaminate drinking water sources in Vietnam [7]. The worldwide contamination of fipronil is clearly interacting with ecosystem and human.

Recent report confirmed the presence of fipronil in urban streams, and is highly toxic to many steam invertebrates, with a mean 96-hour viability inhibition $\mathrm{EC}_{50}$ values as low as 32.5 ng/L for Chironomus dilutus [8]. Additionally, fipronil is highly toxic to many fish species, with reported 96-hour $\mathrm{LC}_{50}$ level as low as $0.246 \mathrm{mg} / \mathrm{L}$ for rainbow trout and $0.083 \mathrm{mg} / \mathrm{L}$ for bluegill sunfish [1]. It also has a tremendous negative impact on non-target insect, such as honey-bee [9]. Although fipronil binds more selectively to insect GABA receptors than mammal GABA 
receptors, long term toxicity study showed it increased thyroid follicular cell tumor in rats [10, 11]. The U.S. Environmental Protection Agency has therefore classified fipronil as a possible human carcinogen [10]. Even though there is an overall increase in the knowledge of how fipronil is impacting the environment and human health, large knowledge gap still exist in terms of its environmental fate and resides in various media, such as soils and agricultural products [12]. Thus, it is important to monitor the exposure level of fipronil in the environment.

Currently, the detection of fipronil level in environmental and biological samples are mostly dependent on chromatographic methods, such as gas and/ or liquid chromatography coupled with mass spectrometry [13-16]. These methods are sensitive, but costly, time and labor intensive. There have been reported uses of antibody-based enzyme-linked immunosorbent assays (ELISA) to detect total fipronil in human blood samples and artificially contaminated tap water samples $[17,18]$. However, there are inherent limitations in antibody-based assays, such as difficult or unable to be reused, expansive in production, and may suffer from batch-to-batch variations $[19,20]$. It is therefore necessary to develop low-cost, reusable means to detect fipronil rapidly. One possible way to achieve this is by identifying a single-stranded DNA (ssDNA) Molecular Recognition Element (MRE) that specifically bind to fipronil.

The process, Systematic Evolution of Ligands by Exponential Enrichment (SLEEX) can be utilized to identify such a specific binding element [21]. This in vitro selection process involves repeated cycles of incubation and partitioning between the target of interest and a large library with up to $10^{15}$ different molecules, and amplification of molecules that bind to the target under increasing selection pressures.

This work describes the use of a stringent variation of the SELEX process previously developed by our laboratory to select ssDNA MREs specific for fipronil. This SELEX variant 
emphasizes on introducing multiple, lengthy negative selection rounds to direct the enriched library away from binding to structurally similar molecules and molecules that are likely to coexist in the same environment [22-24]. In this work, major metabolites of fipronil, commonly used herbicides and pesticides, atrazine, malathion and propanil, and a closely related pesticide, ethiprole have been used as negative targets to increase the specificity of the enriched library. Bovine serum albumin (BSA) is chosen to be one of the negative targets, as it is a common blocking agent, and serves as a general protein target. The selection process has been completed, and potential candidate ssDNA MRE sequence has been identified. Future works will be the determination of its binding affinity and specificity to fipronil, and the development of a potential detection assay for fipronil.

\section{A.2 Materials and Methods}

\section{A.2.1 In vitro selection for Fipronil-specific MREs}

Twelve rounds of SELEX were carried out to identify fipronil-specific MREs (Figure A.1).

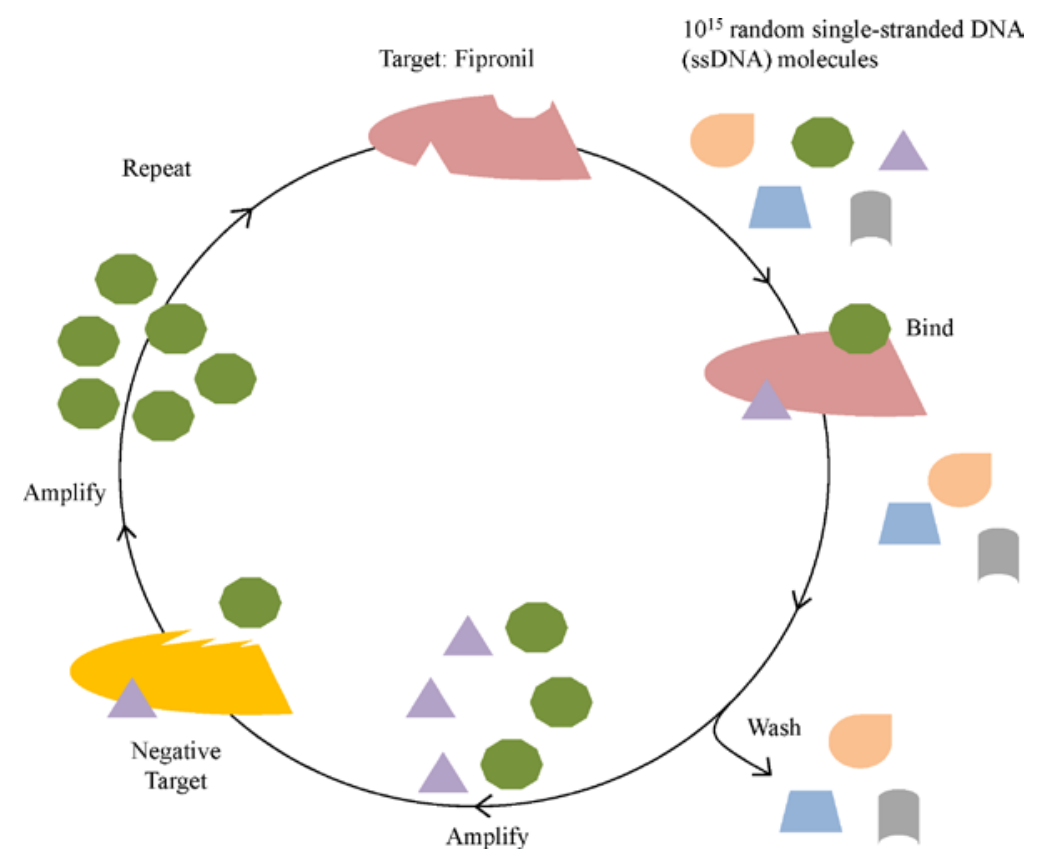


Figure A.1: Illustration of the in vitro selection process. The in vitro selection process begins with up to $10^{15}$ different ssDNA molecules and incubation with the target of interest, fipronil. Molecules bind to fipronil are amplified and subjected to incubation with negative targets. Those that do not bind to negative targets are retrieved and amplified. This completes one round of in vitro selection cycle.

In brief, the selection began with a ssDNA library with up to $10^{15}$ different molecules. This library was previously designed by our laboratory, and designated RMW.N34 [23]. The library consists of two 23-base constant regions for primer attachment during polymerase chain reaction (PCR), flanking by a 34-base random region, and it was commercially synthesized (Eurofins MWG Operon; Huntsville, AL). The stringent selection scheme was designed to enrich molecules that bind to fipronil, but not the negative targets

\section{A.3 Preliminary Results and Future Work}

\section{A.3.1 Round 12 Potential Fipronil-specific candidate MRE}

Twelve rounds of SELEX were carried out to identify ssDNA MREs specific to fipronil. The post round 12 library was analyzed for consensus sequence families, predicted secondary structures and Gibbs free energy values $(\Delta G)$ (indicating stability). These steps were performed similarly to the method described in Chapters 2-4. One candidate sequence, designated R12.51 was present in multiple sequence families, with relatively stable predicted secondary structures, and low Gibbs free energy (-9.28 kcal/mol). 


\section{A.4 References}

1. New-Pesticide Fact Sheet - Fipronil, O.o.P. U.S. Environmental Protection Agency, Pesticides and Toxic Substances, Office of Pesticide Programs, Editor. 1996, U.S. Government Printing Office: Washington, DC. p. 1-10.

2. Caboni, P., R.E. Sammelson, and J.E. Casida, Phenylpyrazole insecticide photochemistry, metabolism, and GABAergic action: ethiprole compared with fipronil. J Agric Food Chem, 2003. 51(24): p. 7055-61.

3. Stone, W.W., R.J. Gilliom, and K.R. Ryberg, Pesticides in U.S. streams and rivers: occurrence and trends during 1992-2011. Environ Sci Technol, 2014. 48(19): p. 1102530.

4. Moran, K.D., Urban Use of the Insecticide Fipronil - Water Quality Implications, in Memorandum prepared for the Urban Pesticides Committee. 2007, TDC Environmental. p. 1-14.

5. Simon-Delso, N., et al., Systemic insecticides (neonicotinoids and fipronil): trends, uses, mode of action and metabolites. Environ Sci Pollut Res Int, 2015. 22(1): p. 5-34.

6. Mize, S.V., S.D. Porter, and D.K. Demcheck, Influence of fipronil compounds and ricecultivation land-use intensity on macroinvertebrate communities in streams of southwestern Louisiana, USA. Environ Pollut, 2008. 152(2): p. 491-503.

7. Chau, N.D., et al., Pesticide pollution of multiple drinking water sources in the Mekong Delta, Vietnam: evidence from two provinces. Environ Sci Pollut Res Int, 2015.

8. Weston, D.P. and M.J. Lydy, Toxicity of the insecticide fipronil and its degradates to benthic macroinvertebrates of urban streams. Environ Sci Technol, 2014. 48(2): p. 12907.

9. Bonmatin, J.M., et al., Environmental fate and exposure; neonicotinoids and fipronil. Environ Sci Pollut Res Int, 2015. 22(1): p. 35-67.

10. Fipronil: Third Reevaluation - Report of the Hazard Identification Assessment Review Committee, H.E.D. U.S. Environmental Protection Agency, Editor. 2000, U.S. Government Printing Office: Washington, DC. p. 1-24.

11. Li, P. and G. Akk, The insecticide fipronil and its metabolite fipronil sulphone inhibit the rat alpha1beta2gamma2L GABA(A) receptor. Br J Pharmacol, 2008. 155(5): p. 783-94.

12. van der Sluijs, J.P., et al., Conclusions of the Worldwide Integrated Assessment on the risks of neonicotinoids and fipronil to biodiversity and ecosystem functioning. Environ Sci Pollut Res Int, 2015. 22(1): p. 148-54.

13. Bichon, E., C.A. Richard, and B. Le Bizec, Development and validation of a method for fipronil residue determination in ovine plasma using 96-well plate solid-phase extraction and gas chromatography-tandem mass spectrometry. J Chromatogr A, 2008. 1201(1): p. 91-9.

14. Duhan, A., B. Kumari, and S. Duhan, Determination of residues of fipronil and its metabolites in cauliflower by using gas chromatography-tandem mass spectrometry. Bull Environ Contam Toxicol, 2015. 94(2): p. 260-6.

15. Jimenez, J.J., et al., Sample preparation methods to analyze fipronil in honey by gas chromatography with electron-capture and mass spectrometric detection. J Chromatogr A, 2008. 1187(1-2): p. 40-5. 
16. Lacroix, M.Z., et al., Quantification of fipronil and its metabolite fipronil sulfone in rat plasma over a wide range of concentrations by LC/UV/MS. J Chromatogr B Analyt Technol Biomed Life Sci, 2010. 878(22): p. 1934-8.

17. Liu, X., et al., Poly- and monoclonal antibody-based ELISAs for fipronil. J Agric Food Chem, 2007. 55(2): p. 226-30.

18. Mohamed, F., et al., Acute human self-poisoning with the $N$-phenylpyrazole insecticide fipronil--a GABAA-gated chloride channel blocker. J Toxicol Clin Toxicol, 2004. 42(7): p. 955-63.

19. Bordeaux, J., et al., Antibody validation. Biotechniques, 2010. 48(3): p. 197-209.

20. Mairal, T., et al., Aptamers: molecular tools for analytical applications. Anal Bioanal Chem, 2008. 390(4): p. 989-1007.

21. Tuerk, C. and L. Gold, Systematic evolution of ligands by exponential enrichment: RNA ligands to bacteriophage T4 DNA polymerase. Science, 1990. 249(4968): p. 505-10.

22. Williams, R.M., et al., In vitro selection of a single-stranded DNA molecular recognition element specific for bromacil. J Nucleic Acids, 2014. 2014: p. 102968.

23. Williams, R.M., et al., In vitro selection of a single-stranded DNA molecular recognition element against atrazine. Int J Mol Sci, 2014. 15(8): p. 14332-47.

24. Williams, R.M., E. Maher, and L.J. Sooter, In vitro selection of a single-stranded DNA molecular recognition element for the pesticide malathion. Comb Chem High Throughput Screen, 2014. 17(8): p. 694-702. 


\title{
Ka Lok Hong, Pharm.D.
}

\author{
174 Birds Eye View Dr. \\ Morgantown, WV 26501 \\ (410)-533-3073 \\ khong@mix.wvu.edu
}

\section{EDUCATION:}

West Virginia University, School of Pharmacy, Morgantown, WV

Doctor of Philosophy in Pharmaceutical and Pharmacological Sciences Candidate, Expected Graduation Date May 2015

West Virginia University, School of Pharmacy, Morgantown, WV

Doctor of Pharmacy, Magna cum laude

Degree received May 2011

University of Maryland, Baltimore County, Baltimore, MD

Pre-pharmacy

\section{RESEACH EXPERIECE:}

Doctoral Student in the Laboratory of Dr. Letha J. Sooter, March 2013 to Present

West Virginia University, School of Pharmacy, Morgantown, WV

- Dissertation project in the identification and biosening application of singlestranded DNA (ssDNA) molecular recognition elements (MRE) or aptamer

- Proficient in in vitro selection (SELEX) of ssDNA MRE targeting proteins, small molecules and bacteria whole cells

- Highly experienced in polymerase chain reaction (PCR), agarose and polyacrylamide gel electrophoresis, DNA purification, bacteria cloning, plasmid isolation

- Highly experienced in analytical assay development, including ssDNA MRE modified ELISA, fluorescence binding assays, Biacore surface plasmon resonance binding and kinetics analysis assays

- Experienced in yeast display single-chain variable fragment (scFv) antibody library

- Experienced in human cell culture, yeast and bacteria culture, metal affinity protein purification, RNA isolation from rat brain tissues and western blot

- Working knowledge in HPLC, flow cytometry, circular dichroism and mammalian cell transfections 


\section{TEACHING EXPERIENCE:}

Guest Lecturer in PHAR 731: Biopharmaceutics and Pharmacokinetics, Fall 2013 and Fall 2014

West Virginia University, School of Pharmacy, Morgantown, WV

- $\quad$ Teaching 3 lectures, 1) Pharmacodynamics and Pharmacogenomics; 2) Respiratory Diseases; 3) Pharmacogenomics and Drug Transport/ Efflux

Graduate Teaching Assistant in the Laboratory of Dr. Letha J. Sooter, March 2013 to Present

West Virginia University, School of Pharmacy, Morgantown, WV

- Mentoring undergraduate students and summer research fellow in experiment design and data analysis

\section{Undergraduate Microbiology Biology Laboratory Teaching Assistant,} January 2007 to July 2007

University of Maryland, Baltimore County, Baltimore, MD

- Facilitating experiment set up, and help grading quizzes and tests

Chemistry Tutor, September 2006 to May 2007

University of Maryland, Baltimore County, Baltimore, MD

- Tutoring freshmen and sophomores on general chemistry and organic chemistry

\section{AWARD \& FUNDING:}

- WVU NanoSAFE Graduate Fellow, August 2013 to present

- WVU Yvonne Stanley Memorial Scholarship, April 2009 and April 2010

- WVU Gerald L Sprowls Pharmacy Scholarship, April 2008

\section{SELECTED PRESENTATIONS:}

Seminar Presentation: KL Hong \& LJ Sooter. “Application of Molecular Recognition Elements”, Pharmaceutical \& Pharmacological Sciences Student Seminar Series, October 2014 at Morgantown, West Virginia

Poster Presentation: KL Hong, K Imlay, L Battistella, RM Williams, KM Hickey, CD Bostick, PM Gannett \& LJ Sooter. "Identification and Diagnostic Application of Molecular Recognition Elements”, Biosensing and Bioselectronic Symposium, April 2014 at Morgantown, West Virginia 
Seminar Presentation: KL Hong \& LJ Sooter. "Selection of Fipronil Specific Molecular Recognition Elements by Decoy-SELEX”, Pharmaceutical \& Pharmacological Sciences Student Seminar Series, March 2014 at Morgantown, West Virginia

Seminar Presentation: KL Hong \& LJ Sooter. "Fipronil Molecular Recognition Elements and Surface Plasmon Resonance Utilization”, Pharmaceutical \& Pharmacological Sciences Student Seminar Series, November 2013 at Morgantown, West Virginia

Clinical Rotation Presentation: "Clozapine use in Schizophrenia", $4^{\text {th }}$ year Pharmacy Rotation, February 2011at United Biosource, Morgantown WV

Clinical Rotation Presentation: “Dabigatran vs Warfarin”, $4^{\text {th }}$ year Pharmacy Rotation, December 2010 at Morgantown, West Virginia

Clinical Rotation Presentation: "Dosing in Obesity - One size fits all or not", $4^{\text {th }}$ year Pharmacy Rotation, September 2010 at Veteran Affairs Medical Center, Martinsburg, West Virginia

Clinical Rotation Presentation: "Review on efficacy, safety and patient satisfaction of Liraglutide, a one-daily human GLP-1 analogue", $4^{\text {th }}$ year Pharmacy Rotation, August 2010 at Veteran Affairs Medical Center, Martinsburg, West Virginia

\section{PUBLICATIONS:}

KL Hong, L Battistella, AD Salva, RM Williams and LJ Sooter. 2015. "In vitro selection of single-stranded DNA molecular recognition elements against $S$. aureus alpha toxin and sensitive detection in human serum" International Journal of Molecular Sciences. 16(2): 2794-2809

KL Hong, E Maher, RM Williams and LJ Sooter. 2015. "In vitro selection of single-stranded DNA molecular recognition elements against Clostridium difficile toxin B and sensitive detection in human fecal matter" Journal of Nucleic Acids, vol. 2015, Article ID 808495, 12 pages. doi: 10.1155/2015/808495

KL Hong, K Yancey, L Battistella, RM Williams, KM Hickey, CD Bostick, PM Gannett and LJ Sooter. 2014. "In vitro selection of single-stranded DNA molecular recognition elements against Exotoxin A and sensitive detection in human serum” Under revision, PLoS One 
KL Hong and LJ Sooter. 2015. "Recent advancement in biosensing of pathogens and toxins based on single-stranded DNA molecular recognition elements" Under review, BioMed Research International

RM Williams, AR Kulick, S Yedlapalli, L Battistella, CJ Hajiran and LJ Sooter. October 2014. "In vitro selection of a single-stranded DNA molecular Recognition element specific for bromacil.” Journal of Nucleic Acids, acknowledgement in manuscript preparation

\section{OTHER EXPERIENCE:}

Pharmacy Intern, Summer 2009

Giant Pharmacy, Annapolis, MD

Pharmacy Intern, Summer 2008

CVS Pharmacy, Frederick, MD

\section{LICENSE:}

Pharmacist License No. 20322, August 2011 to Present

Maryland Board of Pharmacy

\section{ORGANIZATIONS:}

Member of American Pharmacist Association

Member of American Chemistry Society

\section{LANGUAGE:}

Native Level in Mandarin and Cantonese Chinese

Working knowledge in Japanese

\section{ACTIVITIES:}

WVU School of Pharmacy Eastern Division Newsletter Co-editor, August 2010 to April 2011

Academy of Student Pharmacist Treasurer, May 2008 to May 2010 


\section{REFERENCES:}

\section{Letha Sooter, Ph.D. (Advisor)}

1 Medical Center Dr.

Morgantown, WV

email: lsooter@hsc.wvu.edu

phone: 304-293-9218

Yon Rojanasakul, Ph.D. (Committee member)

1 Medical Center Dr.

Morgantown, WV

email: yrojan@hsc.wvu.edu

phone: 304-293-1476

Lena Maynor, Pharm.D., BCPS (Pharmacy clinical practice preceptor)

1 Medical Center Dr.

Morgantown, WV

email: lmaynor@hsc.wvu.edu

phone: 304-293-1457 